


\section{Universal Sanctum}

For ANYONE from ANY RELIGION seeking SPIRITUAL REALISATION through contemporary INTERIOR architecture

By Shamal Nikita Nanji

A 120 point thesis submitted to the School of Architecture and Design, Victoria University of Wellington, in the partial fulfilment of the requirements for the Degree of Master of Interior Architecture.

Victoria University of Wellington,

School of Architecture and Design

Thesis Supervisor: Daniele Abreu e Lima 



\section{ABSTRACT}

In the realm of religion, when rituals and prayers become a routine or a default reaction, often prescribed by elders, they lose value and meaning. In the modern era, we have distanced ourselves from the past ideals of religion. Nevertheless, we continue to seek meaning in life beyond material objects. The connection to the innerself establishes this meaning and purpose. From this understanding I realised that all religions, despite their subtle differences lead to spirituality and enlightenment. The idea that architecture can provide a universal middle ground between people and which they truly seek, is the context from which my thesis proposal derives from.

My thesis question:

How can the design of a Universal space of spiritual devotion be realised through exploration and manipulation of spatial qualities within sacred architecture, in a contemporary inner-city context?

Thus, this thesis will look into the architectural genre of Sacred Space in a contemporary setting. The objective will be to investigate the significance of sacred architecture and the common qualities between the various religions and their respective places of worship. The focus will be to propose an interior space which can be deemed sacred by any one from any religion seeking spiritual upliftment.
In doing so, the space will intend to unify people from different religious and cultural backgrounds, and lead them towards the common goal of connecting with the inner self.

The key theory investigated in this research looks at the case of religion for today's society, interpretation of spirituality in the east and the west, defining sacred architecture and all that it entails, and the need for this typology in the contemporary world.

The contextual basis of this thesis will focus on New Zealand and the predominantly contemporary and diverse culture of the country. The rise in various ethnicities and technological advances means that the presence of a universal space of spiritual reflection and gathering is necessary now more than ever. In my observation, there is a noticeable lack of contemporary sacred architecture, in New Zealand. Perhaps this is the result of our predominantly Secular society. My proposal will aspire to see through this absence and attend to the need of spatial experience to mediate between people and which they spiritually seek. 



\section{ACKNOWLEDGEMENTS}

I would like to take this opportunity to express my gratitude towards those who have helped me see through the years of intense study.

Firstly I would like to thank my supervisor, Daniele. Thank you for your continuous guidance throughout my thesis. Your extensive wealth of knowledge is deeply appreciated.

Thank you to all the lecturers and tutors at Victoria University, School of Architecture, who have helped me with my thesis. A specific mention to teaching assistant Alice Harland Andersen for giving me advice during the design phase.

Thank you to my parents Jayesh and Usha Nanji for supporting me throughout my five years at university, and particularly believing in me to achieve whatever I set my mind to.

Thank you to my extended family members for your encouragements. Especially to my Grandmother Kanta Nanji for your words of wisdom, and to my aunty Ashika Nanji for when I needed reassurance.

Thank you to my younger brother, Hari Nanji. You always cheered me up whenever I was stressed.

Lastly I would like to thank all my friends who I have spent the last five years at university with. Without your consultations, I would have not been able to complete my studies. 



\section{TABLE OF CONTENTS}

ABSTRACT V v

ACKNOWLEDGEMENTS vii

CHAPTER ONE - Introduction $1-6$

1.0 Initial Statement 3

1.1 Problem Statement 3

1.2 Research Question 3

1.3 Research Aims 3

1.4 Research Objectives 3

1.5 Scope: Universe of Study 4

1.6 Thesis Structure 4

CHAPTER TWO - Methodology $7-12$

2.0 Introduction 9

2.1 Intended Method 9

2.2 Developed Method 9

2.4 Conclusion 10

CHAPTER THREE - Religion \& Architecture 13-34

3.0 Introduction 15

3.1.1 Definition of Religion 15

3.1.2 Significance of Religion in the Contemporary World 15

3.2.1 Spiritual Philosophy of the East and West 18

3.2.2 Carl Jung and the Mandala 20

3.3 The Mediating Role of Architecture in Religion 20

3.4 Common Spatial Qualities - Precedent Matrix 27

3.5 The Case for Contemporary Sacred Architecture 31

3.6 Conclusion - The Need for this typology in New Zealand 34 
4.0 Introduction

4.1 Why New Zealand?

4.2 Sacred within the City

4.3 Pilgrimage

4.4 Analysing the Sacred Site 41

4.5 Historical Analysis $\quad 57$

4.6 Conclusion $\quad 57$

CHAPTER FIVE - Sacred Spatial Manifestations

$61-82$

5.0 Introduction

5.1 The Water Temple

5.2 Yad Vashem Holocaust Museum 69

5.3 Water and Architecture $\quad 75$

5.4 Earth and Sky

5.5 Conclusion $\quad 82$

CHAPTER SIX - Preliminary Design Experiments $\quad 87-104$

$\begin{array}{ll}6.0 \text { Introduction } & 89\end{array}$

6.1 Paper Experiments $\quad 89$

6.2 Site Diagramming and Programmatic Schemes 89

6.3 Aesthetic Qualities - Precedent Matrix 92

6.4 Experiment One 95

6.5 Experiment Two 95

6.6 Revisiting theoretical research and site exploration 103

6.7 Redefining the design approach 103 
7.0 Introduction

7.1 Holistic design sketching and modelling

7.2 Developing Narrative

107

$\begin{array}{ll}\text { 7.3 Conveying Myth through design } & 107\end{array}$

7.4 Final Design Result 112

$\begin{array}{ll}\text { 7.5 Critical Reflections } & 137\end{array}$

CHAPTER EIGHT - Conclusion \& Critical Reflections

$139-142$

8.0 Why expressing the Sacred through design is important

141

8.1 Conclusions from the investigation

$\begin{array}{ll}\text { 8.2 Constraints of the research } & 141\end{array}$

$\begin{array}{ll}\text { 8.3 Development } & 141\end{array}$

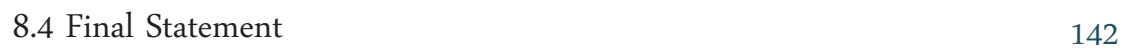




CHAPTER ONE 


\section{INTRODUCTION}

\subsection{Initial Statement}

As a Hindu, born and bred in New Zealand, I have been exposed to a variety of different religions and cultures throughout the years. Growing up with a balanced background between the Kiwi life, which included attending a catholic highschool, and an Indian upbringing, enabled me to have an open view on matters of the everyday. Over the years I have sub-consciously observed the relationship between people, rituals, and the space in which they are practiced in. The view I have developed so far is that rituals are a part of a belief system which one adopts.

\subsection{Problem Statement}

Modern society has pushed the 'sacred' aside. The exponential rise in technology and sciences has led people to become engrossed in materialistic and worldly possessions and relationships. Connection to the sacred is our innate yearning which can only be fulfilled through spiritual experience and service to others. Historically, religious institutions offered this opportunity to grow spiritually as exclusive communities. Current secularised society has little reference to architecture which can enable our spiritual progress.

For societies to progress in a positive manner, we need to establish a balance between the rational entities of the physical world and experiences of the spiritual realm. In a multi-diverse city, the presence of an interior space which can bring together people from different cultural and religious backgrounds, and mediate between them and the divine is necessary to establish this balance and revive the sacred through contemporary means.
1.2 Research Question;

How can the design of a Universal space of spiritual devotion be realised through exploration and manipulation of spatial qualities within sacred architecture, in a contemporary inner-city context

1.3 Research Aims

- To test whether an interior space can be perceived as sacred by people from many different religious and cultural backgrounds

- To test whether architecture can act as mediator between humans and their spiritual self

- To test the means of creating sacred architecture which can respond to the current contemporary context and environmental setting

1.4 Research Objectives

- Manipulate specific spatial qualities such as light, geometry, materials etc. which are commonly recognised within the typology of sacred architecture and therefore enable a space to be universally accepted.

- How sacred spaces can support spiritual awareness and in turn bring a sense of peace into the environment through interior architecture

- Establish the need for this typology in current society and respond specifically to the contextual setting of cosmopolitan Wellington.

- Achieve an example of sacred architecture for a contemporary society. 
1.5 Scope: Universe of Study

Setting the scope of research at the beginning of the thesis enables the topic to be focused. The essential theme of Universal Sanctum is 'sacred architecture' which narrows down to;

1) Communal and individual spaces

2) For anyone, regardless of religion

3) Contemporary design principles with reference to specific design principles used in sacred spaces

To clarify the scope of research, I examined all the specific areas which needed to be addressed and defined the areas which would be omitted.

My thesis will involve the components of a typical design-led research consisting of theoretical, contextual and typological framework. The key findings from this research will facilitate the development of a design solution which responds my thesis aims and objectives. (Fig. 1)

\subsubsection{Literature Review}

The first component of my research question demands an understanding of religion and how its role historically has shifted in today's society. This will lead to an analysis of how religion and spiritual experience is understood by both Eastern and Western philosophical thought. To address the aims and objectives of this my thesis, the literature review will examine architectural means of connecting people with the divine, and whether the modern world is in need of such a typology. Key Philosophers and theorists Bryan Wilson, Pantanjali, Carl Jung, Thomas Barrie and Karsten Harries explore issues based around religion and how architecture can provide meaning to human existence and experience.

\subsubsection{Context}

The next chapter will analyse the context set up by this thesis. The aims and objectives of my thesis require an extensive review of context as the design needs to respond to the current contemporary perspective. Wellington City exhibits qualities of contemporary culture and architecture therefore it is an ideal setting to test the design experiments. The analysis of the site will range from social, contextual, physical and historical.

\subsubsection{Project Review}

In the interior architecture discipline, inspiration is crucial for the design process. Key case study manifestations which showcase universally employed spatial qualities will be analysed as part of this final component.

1.6 Thesis Structure

My thesis follows a linear progression involving iterations between design experimentation and research leading to the development of a design which responds to my initial aims and objectives. (Fig. 2) The step by step process will be imperative for me to follow in order for me to attend to the complexities of this research thesis. 
Ethnicity

\section{Religion}

Sacred Space

New Zealand

Divine

Interviews

Mysticism

Western

Secularisation

Value

Eastern

Pilgrimage

UNIVERSAL SANCTUM

Orientation

Transcending space

Experiential

Spirituality

Narrative

Consciousness

Site Conditions

Sensory

Site History

Memory

Spatial Qualities

Symbolism

Contemporary 


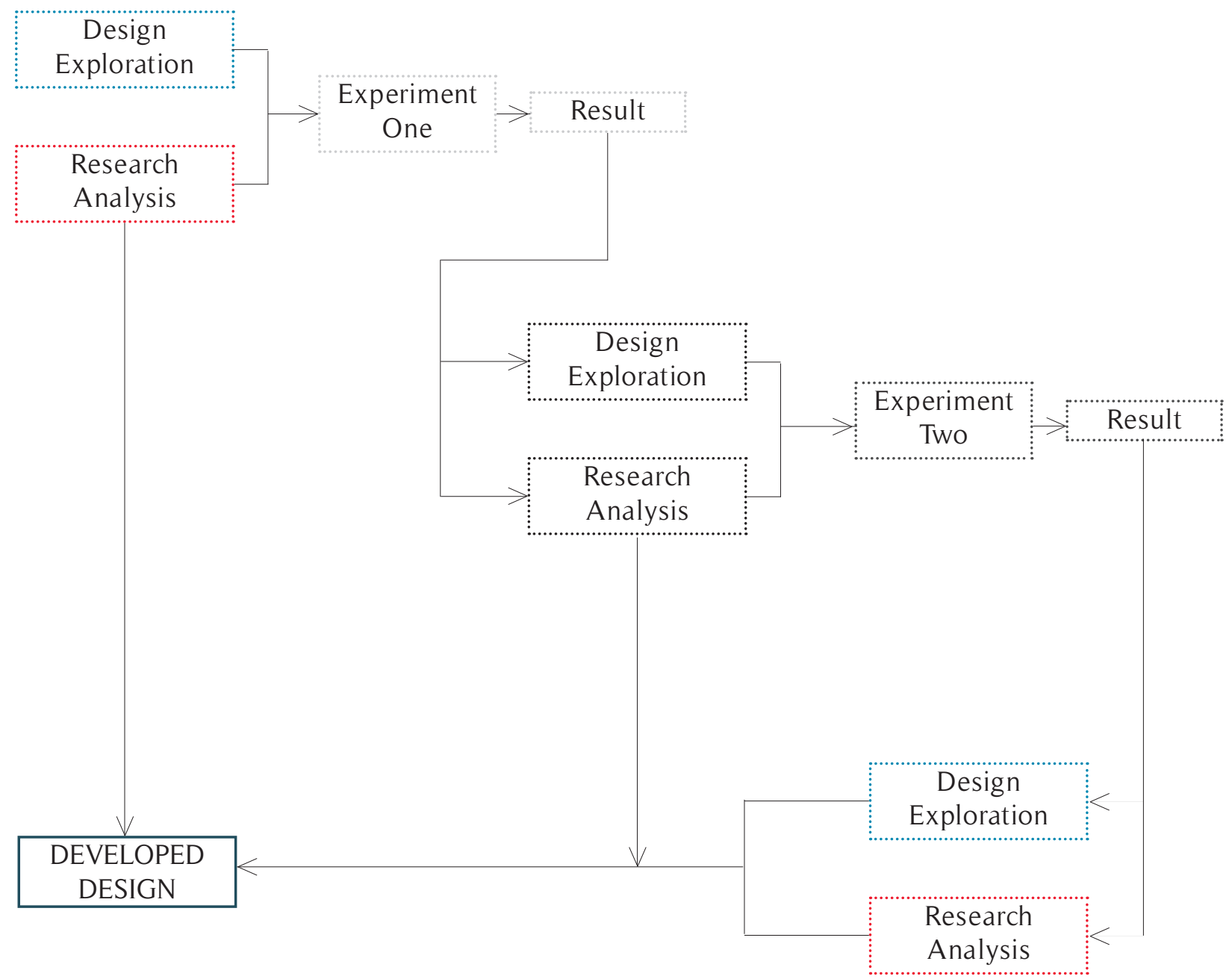

Figure 2) Flow chart diagram illustrating the linear progression of an interative thesis structure 
CHAPTER TWO 


\section{METHODOLOGY}

\subsection{Introduction}

This chapter reviews the methodological techniques I followed in the process of my thesis. The initial methods of research will be explained, referencing philosopher René Descartes' discourse on the Rational Method. This will lead into how I used this method to tackle the early stages of the thesis. I will explain how the initial intention of a linear process to my thesis evolved into using a progressive iterative method influenced by philosopher Michel Foucault. Following these methodological processes resulted in a thesis structure which attends to the aims and objectives of the research.

\subsection{Intended Method}

The theme of this thesis is unintentionally complex and therefore requires a step by step process to understand all the areas outlined in the scope of research. The Rational Method, developed in 1637 by prominent French philosopher, René Descartes, explores rationalisation techniques. The basis of this method is that every step in a process should be broken into the smallest steps. Nothing relevant to the area of research should be excluded. ${ }^{1}$

Using this strategy, I first established all the key areas I would need to investigate for this research. This led into diagramming these key areas into an Organogram which illustrates a defined and ordered approach for the twelve months of study. This detailed diagram is sectioned into two main components; exploration, and research analysis. The intention for my thesis process was to research, and to design simultaneously. According to my Organogram, these two components then merge into the design phases resulting in a well structured final result which responds to the aims and objectives of the research. (Fig. 3)

\subsection{Developed Method}

Throughout this year of study, I consistently referred to my Organogram which helped me to determine which steps to take in my progress. However, the feedback from the periodical critical reviews, changed my intended linear process of research. I immersed into the design stages at the beginning of the thesis, and whilst I was researching, I had not implemented my findings directly into the design. Consequently, the two components were not cohesive. This led me into a cyclical and iterative process of evaluating design decisions, then referring to research analysis, and back to the design. (Fig. 4)

The various research, design and exploration processes I went through, prior to the final design stage, was important to reflect upon. I evaluated the areas were progressing successfully and which areas needed developing. This reflection enabled me to critically define the point of my thesis and what I wanted to achieve.

I initially intended for the result of my design to incorporate specific architectural elements from each religion. I later realised that the function of my design was not to be specific to various religious groups, but to all people of Wellington in general. Thus the need for interviewing specific groups of people as initial research was disregarded. This realisation helped me to develop a solution which holistically responded to the research problem.

My developed method was inspired by modern philosopher Michel Foucault's basic principles. He coined the term power-knowledge which simply denotes that the knowledge gathered from studying information, reinforces power. He believed that power does not come from institutions such has government bodies, or 
certain religious groups, but it is universally embodied within people and knowledge. ${ }^{2}$ This understanding is useful to the various stages of my thesis and affirms the direction of the process.

\subsection{Conclusion}

The overall structure of my thesis was a linear progression from beginning to end with evaluations at various stages. My research explores all the specific elements which inform the design including analysis of relevant literature, extensive site findings, and specific case studies which express sacred architectural qualities. These elements are logically sequenced by the following chapters as a constructed argument which is specific to my thesis. 
MONTHS

0-1

Preliminary

Thesis Stage

Exploration

Component

Narrowing Design Concept

Developing Design
DESIGN LANGUAGE
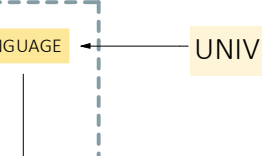

UNIVERSAL SANCTUM
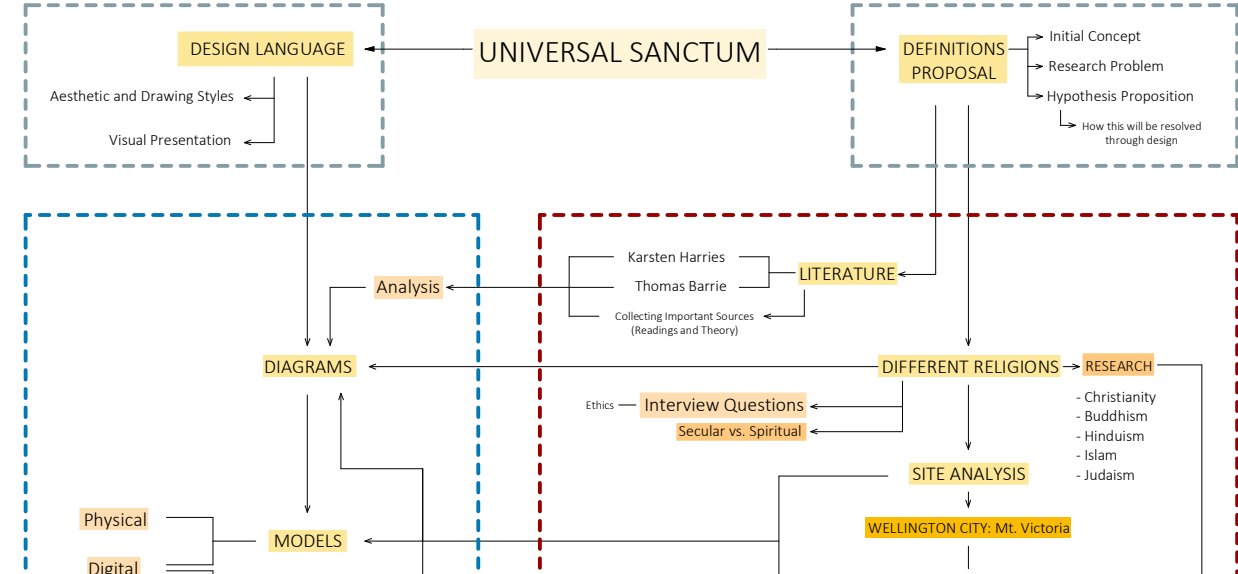

Analogue

$$
\text { DIAGRAMS }
$$

Collecting Important Sources
(Readings and Theory)

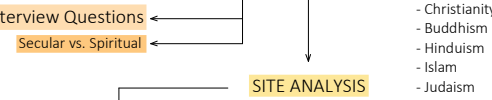

SITE ANALYSIS $\quad$ - Islam

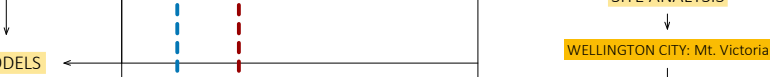

| Analysis Component

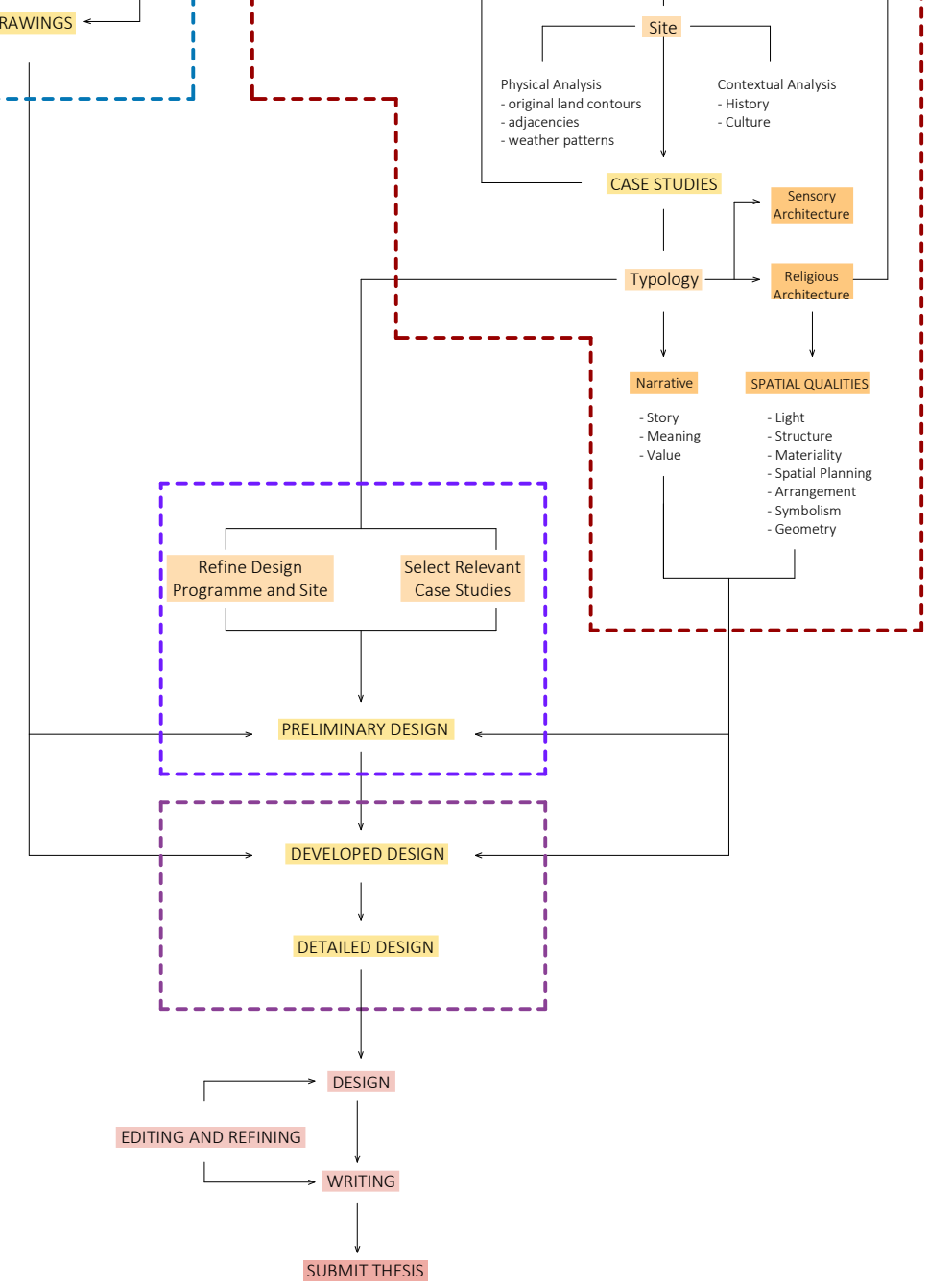

Figure 3) Organogram chart showing methodological process established at the start of my thesis. The diagram illustrates the 12 month process, breaking down the various stages into small steps as referenced by Cartesian rationalisation methods. 


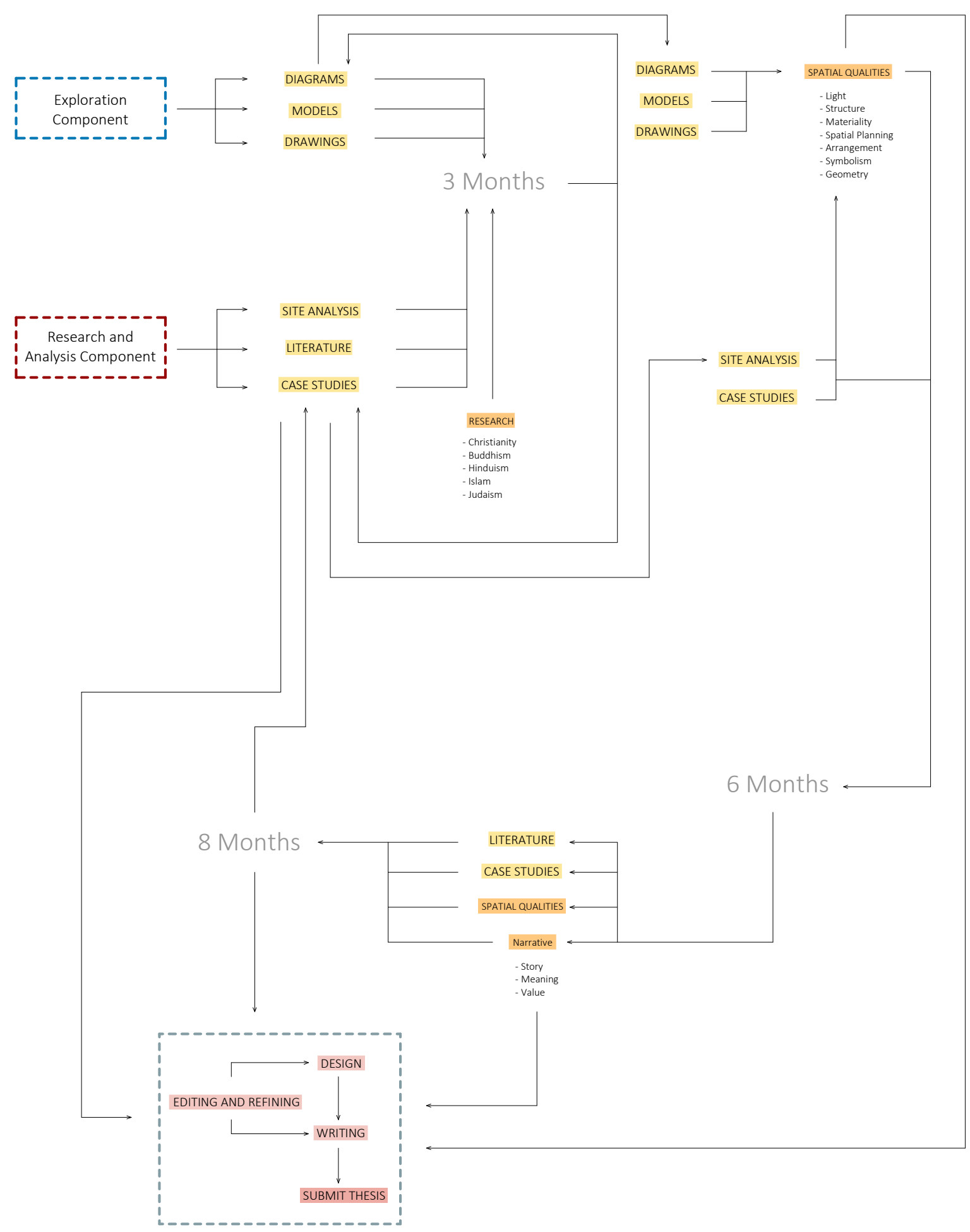

Figure 3) Organogram chart showing methodological process established at the start of my thesis. The diagram illustrates the 12 month process, breaking down the various stages into small steps as referenced by Cartesian rationalisation methods. 
CHAPTER THREE 


\section{RELIGION \& ARCHITECTURE}

\subsection{Introduction}

This chapter follows the origins of my twelve month thesis looking at the theoretical basis which was gathered to help develop the thesis into an interor architectural proposal. This section will first discuss the concept of 'religion' and its meaning to contemporary society. It will then look at the fundamental principles of religion in the East compared to the West, in order to explain how spirituality is understood psychologically. This will be followed by discussions on religious architecture, examining common spatial qualities found in this typology, and the current need for sacred space in the modern world. This chapter will provide critical insight for the design development process, in turn responding to my initial aims and objectives of this thesis.

\subsubsection{Definition of Religion}

The etymology of the word religion originates from the Latin word Ligare which translates to 'to bind'. ${ }^{1}$ The meaning of 'to bind' suggests forming connections with the divine. ${ }^{2}$ However, many sources reveal that this particular meaning of religion is not commonly accepted. ${ }^{3}$ Perhaps this is because religion is a personal journey and different people have different perceptions of it, as it is subjective to experiences, and cultural or moral backgrounds. For my thesis, I will reference religion from various literature which I have examined, as well as regard it from my own perspective. My interpretation of religion is that it provides various paths which lead us in our spiritual journey to an elevated consciousness where we can experience ultimate happiness and harmony with the universe. However, I also understand that in some religions, penance and guilt is the approach they believe will lead them to their ultimate goal. (Fig. 4)
3.1.2 Significance of Religion in the Contemporary World

The history of religion dates back thousands of years, maybe even back to the beginning of humanity. This is because one of the most innate yearnings has always been for the understanding of the world and un-explained phenomena which intrigued the rational mind. For this thesis to be of any value and interest in today's society, the primary concern of the research needs to revolve around post-modern thinking. However, it is also important to reflect and acknowledge how the meaning of religion for humanity has changed overtime.

There is no doubt that change is the hallmark of the modern world. There is constant development that we are involuntarily subjected to, and we are always critically planning the next step. In his book Contemporary Transformations of Religion, Bryan R. Wilson writes about changes in thought processes regarding religion and society, and how religion influences society.

Before modernisation, Religion was the primary agency of social control and of socialisation. Religion exerted a set of beliefs and moral conduct which people needed to follow in order to have a well-functioning society. These religious principles created awareness within people to 'discipline their emotions' or their five senses and restrict them for particular occasions. ${ }^{4}$ People would look at history for precedent of wisdom and morality. Wilson gives an example of Orthodox Churches in the Western world stating that they not only controlled the 'moral fabric moral fabric of society', but influenced matters concerning political, juridical, commercial and social intercourse. (Fig. 5)

The religious approach to constructing society 


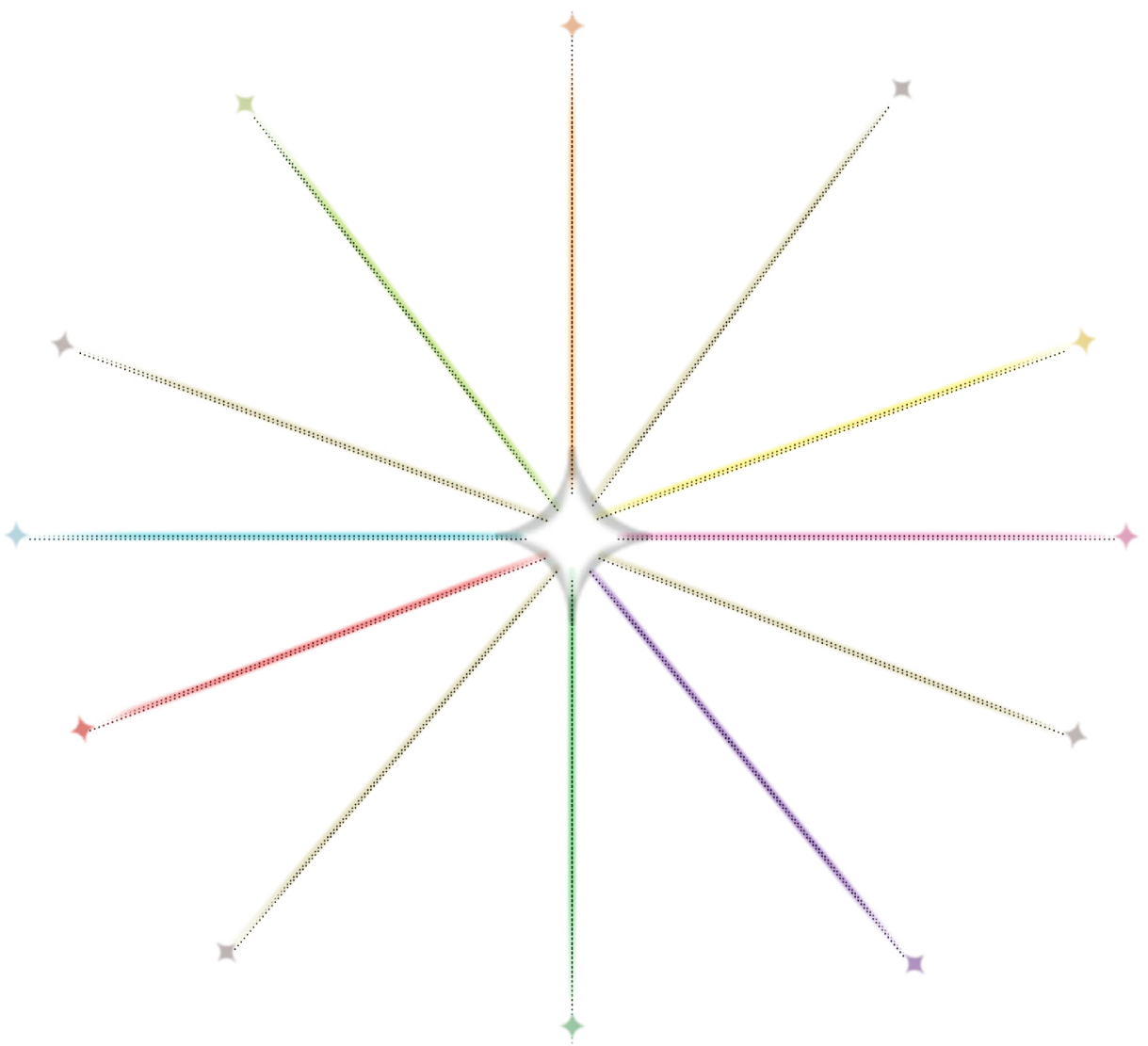

Figure 4) Different religious or spiritual paths from various directions, all leading towards the same goal of spiritual realisation in the centre

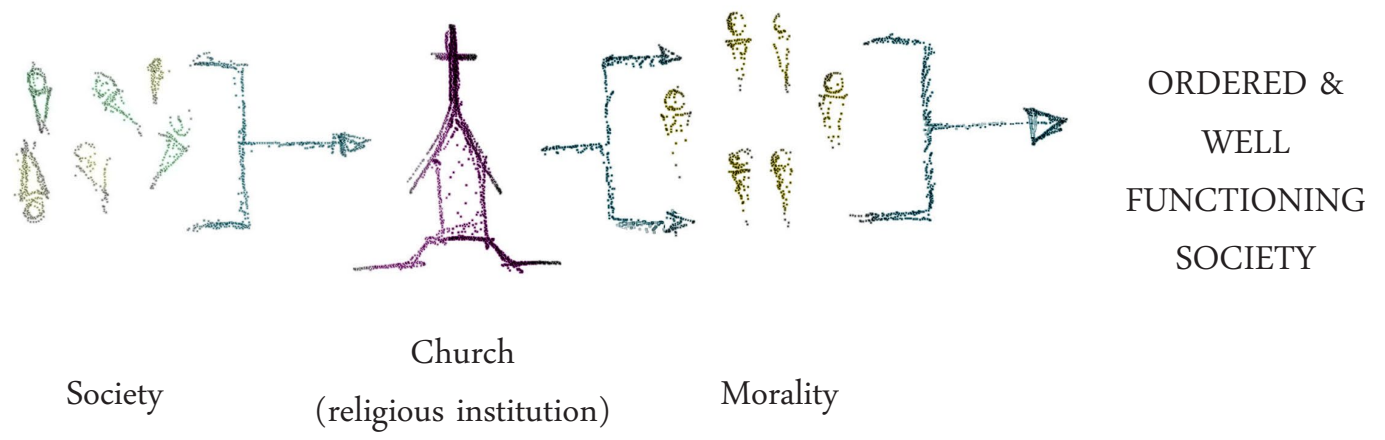

Figure 5) Diagram of the role of religion on society of the past. Religion historically induced moral order of society 
${ }^{4}$ Wilson, B. 2

${ }^{5}$ Wilson, B. $10-12$

${ }^{6}$ Wilson, B. 8

${ }^{7}$ Dawkins, R. 2

${ }^{8}$ Bruce, S. $43-44$

${ }^{9}$ Nietzsche, F. Thus Spoke Zara ...

${ }^{10}$ Wilson, B. 88

${ }^{11}$ Wilson, B. 19

${ }^{12}$ Wilson, B. 20

${ }^{13}$ Wilson, B. 90 - 91

${ }^{14}$ Wilson, B. 90 - 91

${ }^{15}$ Wilson, B. $90-91$

${ }^{16}$ Eliade, M. $102-103$ has changed by the way of Secularisation. Wilson explains that at the beginning of the twentieth century, people were exposed to a multitude of various faiths. This gave awareness to societies of different methods in seeking spiritual realisation, consequently confusing society. ${ }^{4}$ This came as a result of the increase in migration of people, conflicting religious ideas, and technological advances. This led to secularisation as a way implementing order in society. ${ }^{5}$

Secularisation is a movement which implies that people used to believe in religion and now it has been stripped away. ${ }^{6}$ The concept of secular society is not new; Emperor Marcus Aurelius in Ancient Rome proposed complete separation of religion and government. ${ }^{7}$ Nevertheless, secularisation is a debatable hypothesis which is discussed in Steve Bruce's God is Dead: Secularisation in the West in response to the discourse of 'God is Dead' coined by well-known German Philosopher Friedrich Nietzsche. Both Wilson and Bruce clarify that Nietzsche's theory of secularisation does not mean the demise of religion, rather that the power of religion over society has diminished. ${ }^{8}$

This blunt phrase by Nietzsche is proclaimed by the character of the Madman in his book Thus said Zarathustra. The story depicts the search for enlightenment and can be seen as making a bridge between Western understandings of Religion and the Eastern take on the Divine. ${ }^{9}$

Looking back at Wilson's discussions, he explains that the modern world has increasingly rationalised. Rational constructs are machines, electronics, computers and applied sciences which exhibit principles of cost-efficiency, and the elimination of unnecessary investment of time, money and energy. Since religious concerns are not 'deducible to the rational', religion cannot overhaul society. ${ }^{10}$

Wilson describes the way in which people function in society has changed through history. Before the Enlightenment period, people were controlled externally by religious beliefs. This changed to self-individualised control which eventually led to modern thinking of no control or freedom. ${ }^{11}$ In the contemporary era, people do whatever they wish without fear of judgement as long as they follow the regulations prescribed by mechanical or bureaucratic services. ${ }^{12}$ This change contributes to the Secularisation hypothesis, meaning that the role of religion has changed overtime.

Religious centres are now segregated in society when they once were the heart of it. Wilson sates that in the modern world, entertainment as counter-culture contributes more to society. ${ }^{13}$ He explains that religion has not completely lost its purpose among people as we always need reassurance of our salvation. ${ }^{14}$ While technology and modern sciences have taken over society, religion has increasingly become a personal quest or among small groups of people. ${ }^{15}$

This idea is affirmed by Romanian historian of religion Mircea Eliade in his article The Sacred in the Secular world. Eliade discusses the need for an element of the sacred within people in the contemporary age. ${ }^{16}$ Rituals in religion seem insignificant to man today but they were what gave meaning to life for the primitive man. This in Eliade's view has led to the rise in new religious sects as people are continuously looking for purpose in life. ${ }^{17}$ Despite the exceptions of more traditional societies around the world, much of the focus of religion today, draws towards spiritual growth within individuals, rather than controlling society. 
3.2.1 Spiritual Philosophy of the East and West Patañjali and Carl Jung

The core of this thesis is to create an intervention which speaks to all people, regardless of religion, therefore an analysis comparing Eastern and Western spiritual philosophy is necessary in order to investigate the differences and similarities. Canadian Professor of Religious Studies, Harold Coward, examines the spiritual and psychological theories of the East and the West in his comparative study titled Mysticism in the Analytical Psychology of Carl Jung and the Yoga Psychology of Patañjali (1979). Coward specifically compares Patañjali, the prominent philosopher of one of the six schools of Indian Philosophy, to acclaimed Swiss Psychiatrist Carl Jung. In both perspectives, mysticism is comprehended as the experience of a spiritual presence which 'transcends the empirical world'. ${ }^{18}$ However, both ideologies interpret the psychological processes of this experience differently.

\section{SPIRITUALITY in the EAST}

Patañjali is the name of several ancient scholars of India but the particular author Coward discuses in his article is the philosopher who wrote the Yoga Sutras. Coward explains that in Yoga psychology there are three elements (Gunas) of the consciousness; Sattva (brightness/intelligence), Rajas (emotion/passion), and Tamas (dullness/ inertia). These three elements are present by varying degrees in the consciousness. (Fig. 6) For example, those who have had mystical or spiritual experiences have a higher proportion of Sattva in their consciousness. ${ }^{19}$ During meditation, a person who has Sattva as the dominant element has the ability to intensely concentrate on the object which in turn makes them one with the object. Patañjali describes this state by saying that the the mind becomes a 'transparent crystal' which transforms and reflects the object being studied. ${ }^{20}$ The concept of 'becoming one with the object of concentration' is a psychological theory which is present in the majority of Eastern religions including Buddhism, Sikhism and Taoism.

\section{SPIRITUALITY in the WEST}

The well-known theorist and a founding father of psychoanalysis Carl Jung has not only been influential in analytical psychology, but in religious studies, contributing to modern western philosophy, and reinterpreting ancient philosophies of Plato and Aristotle. The core of Jungian philosophy is the theory of Archetypes. He categorises them into 'personal unconscious' and 'collective unconscious'. ${ }^{21}$ (Fig. 7) Personal unconscious is the part of the mind which accumulates life experiences of the past but cannot be consciously recalled. Collective Unconscious is universally shared among people. ${ }^{22}$ Jung suggests that within the Collective Unconscious is the 'God Archetype'. He believes mystical experience occurs when the 'finite, conscious ego' or the self is 'internally replaced by God or the numinous qualities of the unconscious. ${ }^{23}$ Coward explains how Jungian Archetypes are 'psychological mechanisms' which enable us to look beyond the 'narrow encapsulation' of our conscious ego. ${ }^{24}$ For Jung, archetypes are essential in the path to spirituality as they remove us from our conscious mind to a higher level.

\section{EVALUATING the Two Ideologies}

In both viewpoints, the psychological processes are similar: through meditation or spiritual experience, the mind transcends reality. (Fig. 8) However, the way in which the psyche is described by Patañjali as Gunas or the three elements of consciousness, is different to Jung
${ }^{18}$ Coward, H. 324

${ }^{18}$ Yoga Sutra I:41

${ }^{20}$ Patañjali Apud. Coward, H. 330

${ }^{21}$ Fordham, F. $55-128$

${ }^{22}$ Barrie, T. Spiritual Path ... 17

${ }^{23}$ Jung, C. Apud. Coward, H. $326-327$

${ }^{24}$ Coward, H. $326-327$ 
GUNAS of a SPIRITUALLY ELEVATED MIND

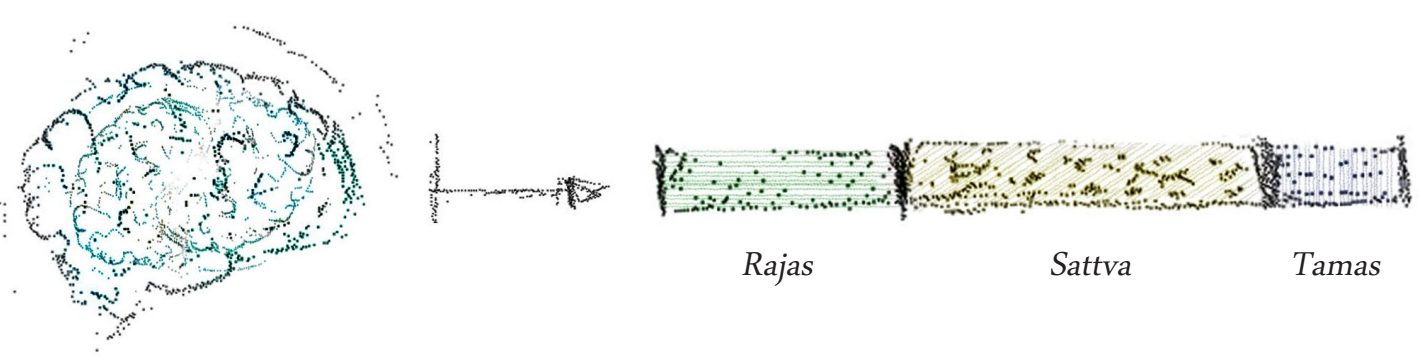

Figure 6) Diagramming analysis of Spirituality understood through Gunas by Patañjali in the Yoga Sutras

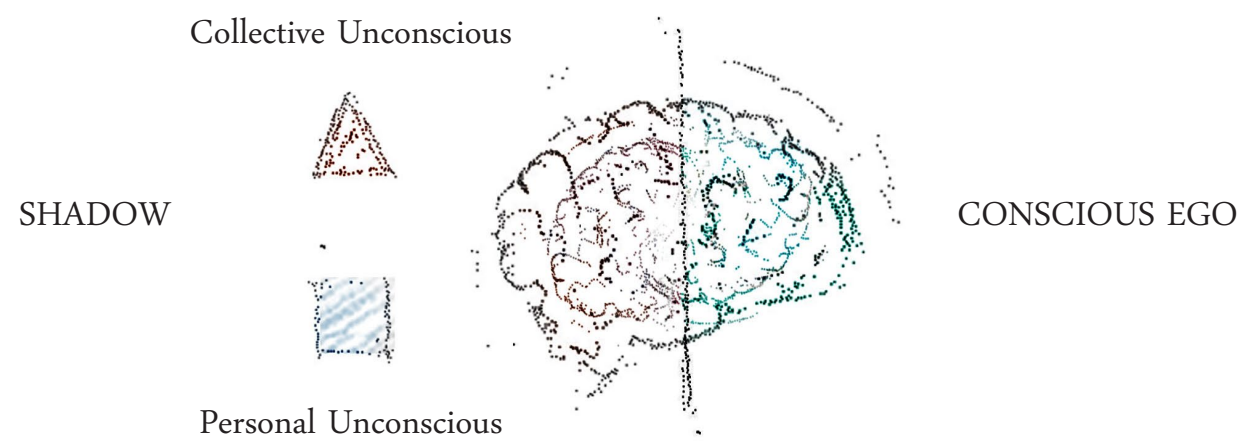

Figure 7) Diagramming analysis of Carl Jung's psychological understandings of Spirituality as personal unconscious and collective unconscious

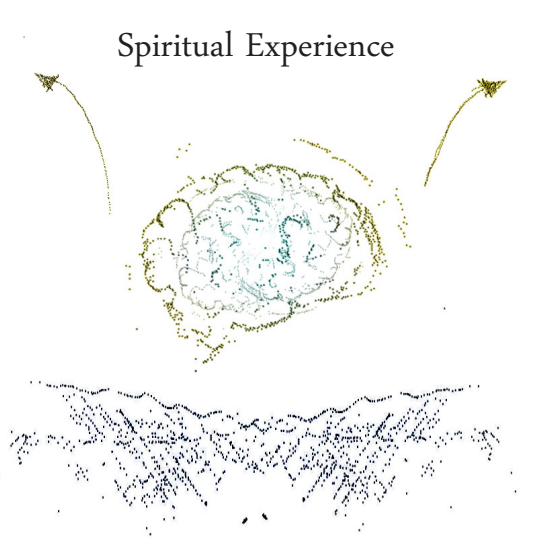

Reality - Physical World 
who refers to the mind as having a conscious ego state and unconscious state with archetypes. ${ }^{25}$ The result of the spiritual experience is also differently expressed. Patañjali's theory reveals that selfrealisation can only occur when the ego is completely removed. The clouded delusions of the world (maya) is overcome and the mind becomes solely sattva, therefore identifying oneself with the whole universe. This concept is commonly accepted and is the basis of religions in the East.

Jung's understandings of psychology in religion have been criticised. ${ }^{26}$ However his explanation of spiritual experience resonates with many Christians and Jews. Coward gives an example from the Book of Paul quoting the common belief "it is no longer I who live, but Christ who lives in me." ${ }^{27}$ This suggests that there is unity between God and the individual but the ego is not completely removed. ${ }^{28}$

Understanding the basis of spiritual belief from both Eastern and Western philosophies is important as each influences the perception of reality. This is useful to my interior design research as it shows that both eastern and western perceive the spiritual experience as the same but differ in the psychological analysis. Since design manifestation is physical and external, it should aim to enable one to experience the universally accepted meaning of spirituality as inward transcendence.

\subsubsection{Carl Jung and the Mandala -}

Universal Symbols seen as comprehensible by all

While working with patients, Carl Jung realised that life has spiritual purpose beyond the material world. ${ }^{29}$ His theories on spirituality are derived primarily from Christianity but also take influence from Hinduism, Buddhism, Taoism and many others. ${ }^{30}$ Through his analysis of various religions,
Jung found that the power of symbolism is most effective for spiritual upliftment, and fundamental to the 'inherent collective unconscious'. In Jung's view, the symbol of the mandala in particular is the most universal, expressing qualities of concentric expansion. He believed that the centre of the mandala is symbolic of the axis of the inner-self and/or universe. ${ }^{31}$

The mandala originates from the Sanskrit word for circle. The symbol can be found in its simple circular forms or more complex geometric patterns of triangles and squares within the circle. ${ }^{32}$ The three shapes have different meanings which form together to create a symbol of universality. As a result of researching Carl Jung's mandala as well as original Hindu and Buddhist connotations, I created a simple symbol as a basis for the theoretical framework of this thesis. (Fig. 9)

3.3 The Mediating role of Architecture in Religion

The following section discusses how architecture acts as a mediator between people and what we seek from the spiritual. The Sacred In-Between, written by architect and professor of North Carolina State University, Thomas Barrie is an integration of scholarly ideas of sacred architecture within philosophy, architectural history and theory, as well as in practice. Barrie explicitly brings to light the depths of sacred architecture and its capacity to evoke spiritual atmosphere through various spatial conditions.

\section{MEDIATION in Architecture}

Mediation is illustrated as 'the middle zone', 'bringing together separate parties' and oscillating 'between discrete entities'. Barrie defines religion as a mediator, connecting the individual and the
${ }^{25}$ Coward, H. 334

${ }^{26}$ Fordham, F. $55-128$

${ }^{27}$ The Book of Paul (Bible) Apud. Coward H. 332

${ }^{28}$ Coward, H. $332-333$

${ }^{29}$ Coward, H. $327-329$

${ }^{30}$ Coward, H. 327 - 329

${ }^{31}$ Simpkins, A. 56

${ }^{32}$ Simpkins, A. 56 


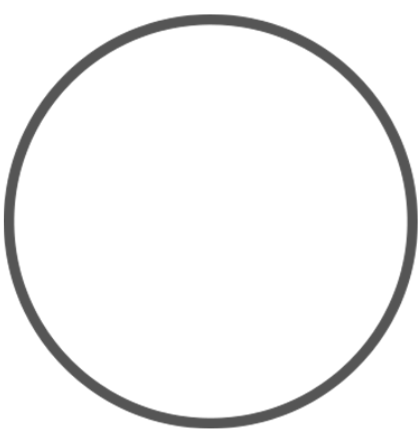

CIRCLE: SPIRIT

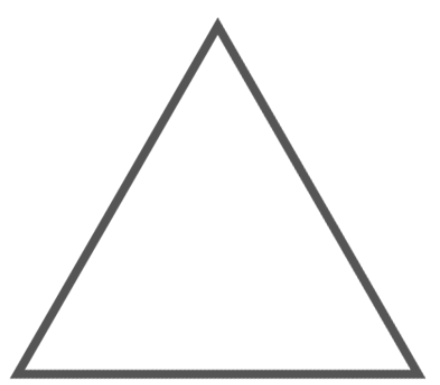

TRIANGLE: SOUL

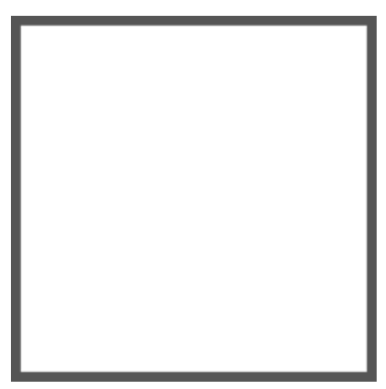

SQUARE: BODY

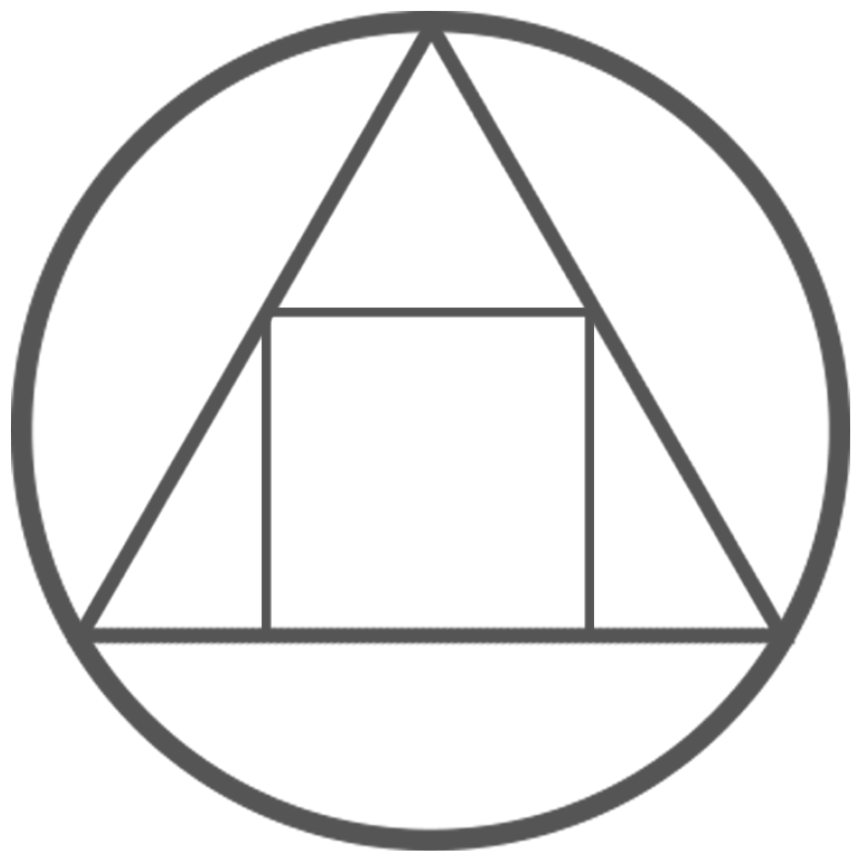

Figure 2) Universal Symbol - mandala

Definitions of each Shape

Circle: The Spirit - truth, unity, everlasting life, continuous expansion

Triangle: The Soul - balance, connection, binding, mind

Square: The Body - the four elements (fire, air, water and earth)

This symbol will be valuable in understanding the basis of my research as well as influential in the diagramming and design process. 


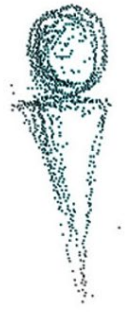

Human

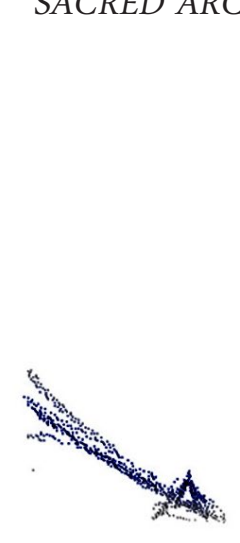

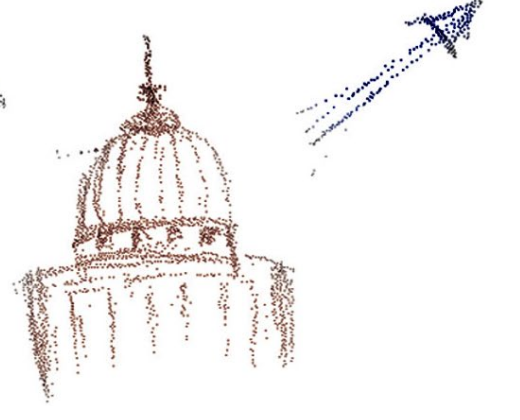

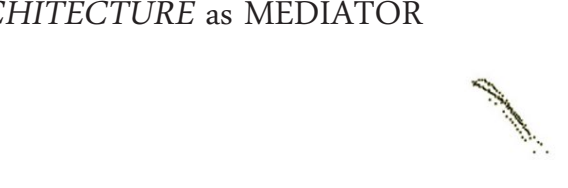

.

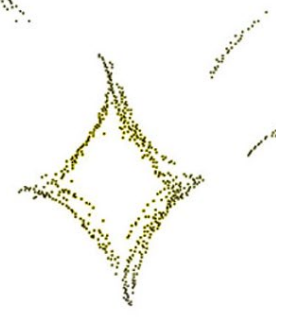

Divine

Figure 10) People connecting to the spiritual realm through spatial means. Architecture seen as the mediator between the two.

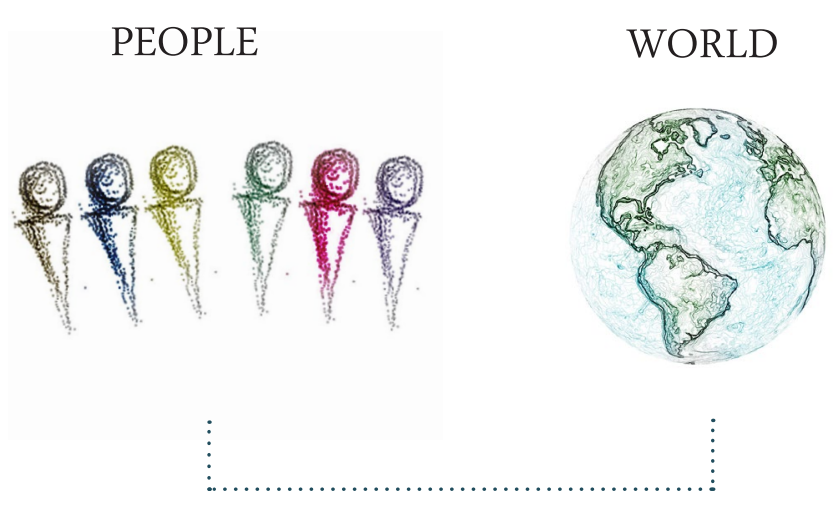

\begin{tabular}{|c|}
\hline relationships \\
\hline love \\
\hline work \\
\hline life \\
\hline death \\
\hline
\end{tabular}

community

\begin{tabular}{|c|}
\hline art \\
\hline friendship \\
\hline
\end{tabular}

Figure 11) Initial thinking process diagram, connecting people (a) to higher purpose in life (b). Derived from literature of Barrie 
community to the gods they worship. He states that mediation, and all its relative terms, include space and spatial relationships. Therefore architecture can also be experienced as a mediator. Sacred architecture in particular, aims to create a 'liminal zone that mediates between humans and which they seek, revere, fear or worship. ${ }^{33}$ It naturally articulates a median zone in the world that is both physical and symbolic. (Fig. 10)

Historically, sacred architecture was created as a physical and symbolic mediator, supporting the religions it was built to serve. Themes of scripture, mythology, and connection to God, were symbolised in sacred architecture. We as humans continuously 'endeavour to establish a place in the world' as we deliberately shape our environment in the 'service of cultural, sociopolitical, and religious imperatives' ${ }^{34}$ (Fig. 11) This physical and symbolic connection which architecture aims to provide, is fundamental to the origins of my thesis topic.

\subsubsection{Mediation through Symbolism}

${ }^{34}$ Barrie, T. The Sacred ... 5-6

${ }^{35}$ Barrie, T. The Sacred ... $42-45$

${ }^{36}$ Jung, C. G. 4

${ }^{37}$ Barrie, T. The Sacred ... 46

${ }^{38}$ Barrie, T. The Sacred ... $42-45$

${ }^{39}$ Barrie, T. The Sacred ... $42-45$

${ }^{40}$ Barrie, T. The Sacred . to be understood as spatial and temporal. (Fig. 12)

Specifically in architecture, external and internal surfaces 'communicate symbolic content' and spatial relationships 'choreograph a dynamic serial experience'. These spatial relationships are developed from form, scale and placement of architectural elements. These elements are sequenced in a manner which links the story together. ${ }^{38}$

Barrie notes how these spatial relationships establish formal hierarchies, aiming to highlight the significance and meaning of the sacred place, which can only be deduced through engagement with the architecture. Symbols in sacred space not only communicated stories but they often symbolised social structures of their time. ${ }^{39}$ (Fig. 13)

Symbolism in the context of sacred architecture is highly powerful, bridging the known with the unknown, and connecting people with their higher-self. Symbolism has the ability to communicate sacred qualities through the details as well as the entire structure, therefore it needs to be the driving force of the design process.

Throughout Barrie's analysis, various spatial conditions are elucidated to express the sacred. These conditions are commonly exampled in religious architecture throughout the world, historically as well as in contemporary spaces. He suggests that the four most essential of these conditions are geometry, proportion, light and materiality. ${ }^{40}$ The essence of the sacred is revealed through experiencing the four spatial qualities which evidently engage people with the architecture. 


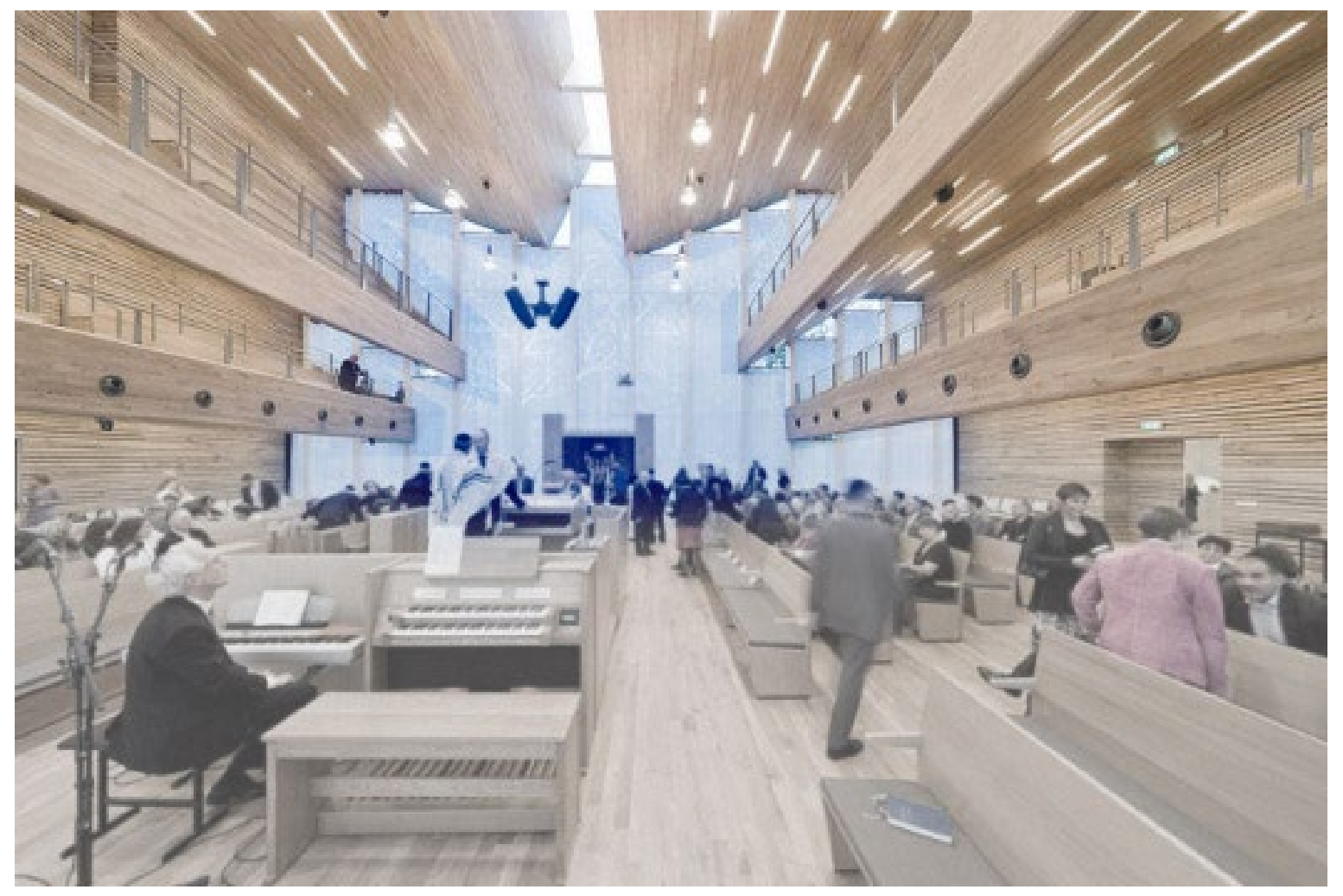

Figure 12) Sacred Architecture has the ability to express symbols spatially rather than through representation. Synagogue LJG by seARCH Architects symbolises the Jewish Menorah spatially through the form of the gallery seating. The menorah form outline is highlighted in blue.
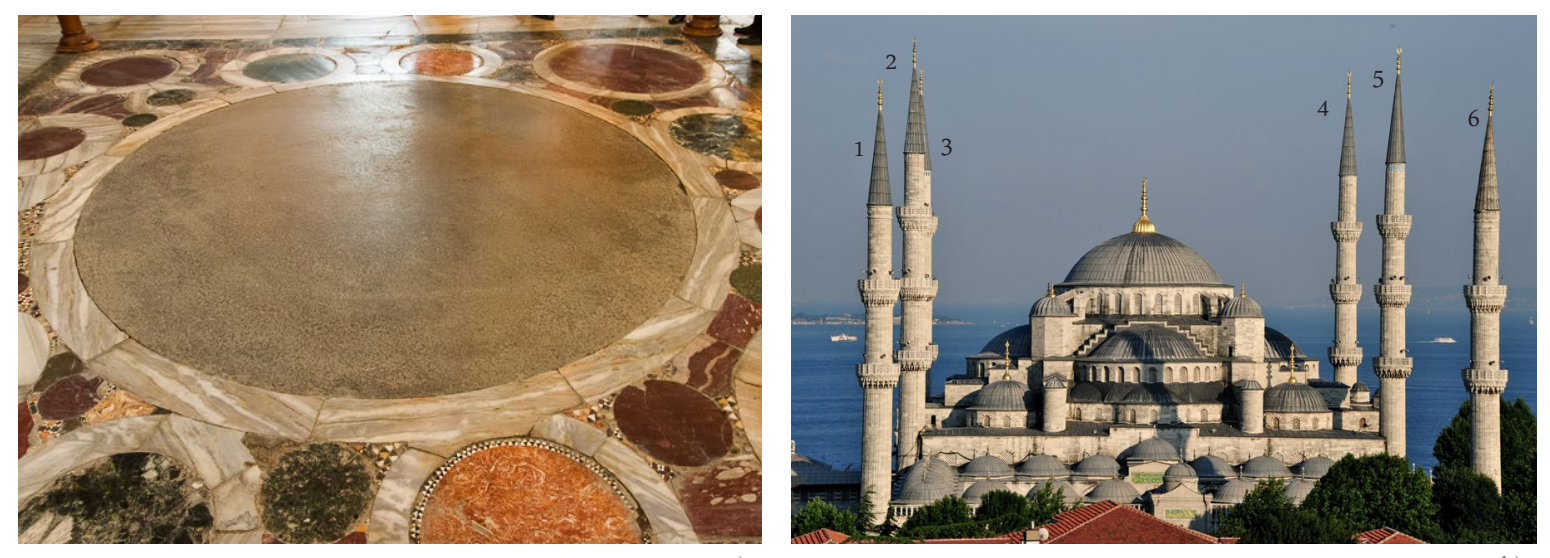

Figure 13 a) Omphalos Stone in the Hagia Sophia symbolised or marked the 'centre' of the Byzantine world and it was where kings were crowned. Hagia Sophia was originally an Orthodox Church before the Persian Invasion, consequently turning it into a Mosque, and now a historic museum. b) The Blue Mosque has six minarets. Only Imperial Mosques have more than more than one minaret, symbolically expressing prestige and hierarchy. 

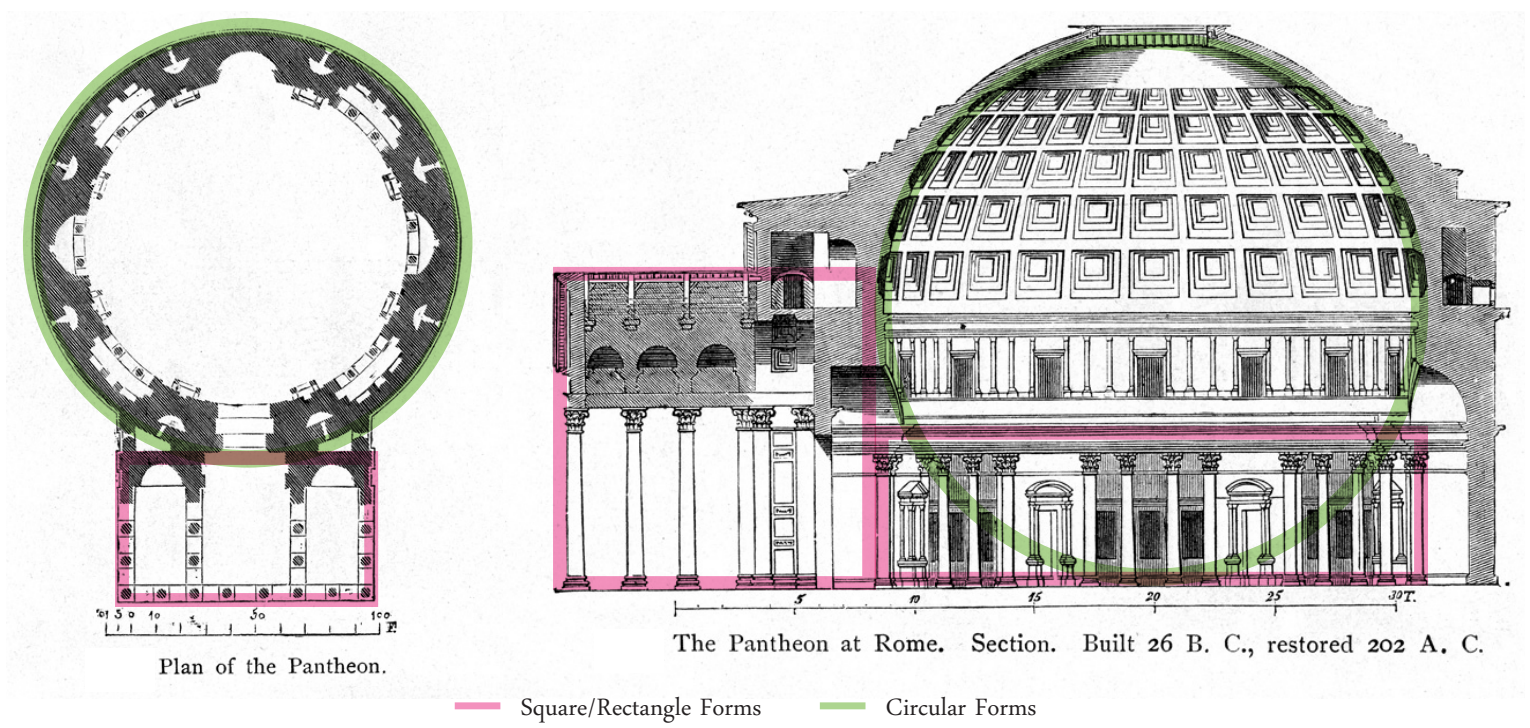

Figure 14) Plan and Section diagrams of shapes deployed in the form of the Pantheon to spatially express the Cosmos 'perfection' of the Gods (circular) and 'ordinariness' of people on Earth (square)
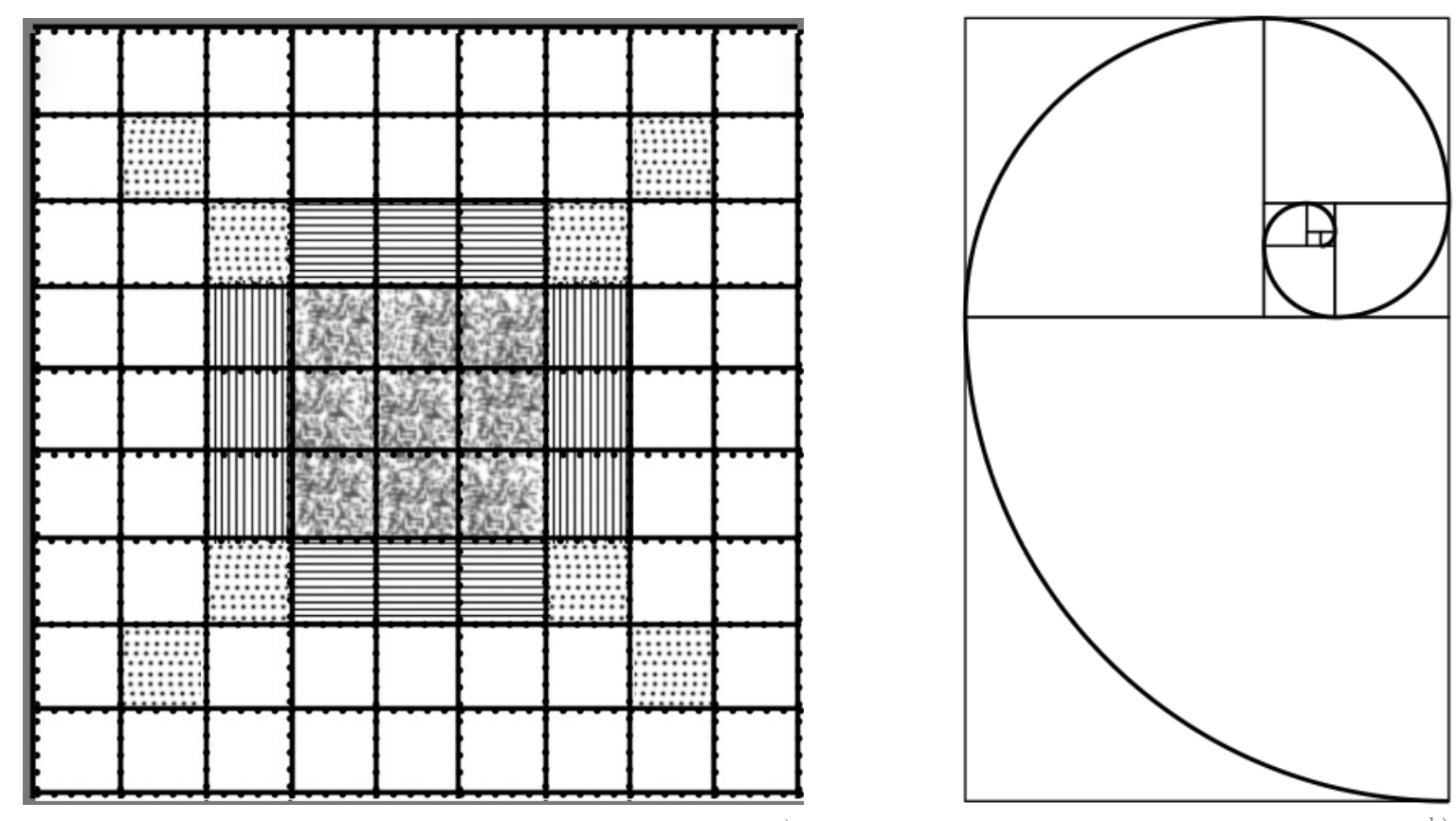

Figure 15 a) Abstracted Vastu Purusha Mandala used by Hindus when constructing important spaces. This mandala in particular comprises of Brahma (the supreme being) in the centre surrounded with the god of the eight cardinal directions. Mandalas in general are used throughout all forms of Eastern architecture including Buddhism, and Taoism as spatial planning devices to ensure harmony and balance of space. 


\section{GEOMETRY AND PROPORTION}

Geometry is embodied throughout nature furthermore in the constructed and material environment. The word geometry is of Greek origins translating to the measuring (metria) of the earth (geo). ${ }^{41}$ Geometry and proportion go hand-in-hand as they often serve to create the 'critical relationships essential to coherent and efficacious sacred architecture.' Barrie describes the practice of geometry as a means to 'articulate divine orders.' ${ }^{42}$ The universe is traditionally seen in scriptures and mythology as 'perfectly ordered' through proportion and geometry. Barrie gives the example of Rome's Pantheon which was designed to symbolise the cosmos. ${ }^{43}$ The simple sphere over the cube renders pure spatial geometry through plan and section rather than through iconography. (Fig. 14) Analogous to Jung, Barrie writes about the use of geometry and proportion relating to the mandala. ${ }^{44}$ Indian design principles deploy the Vastu Purusha mandala which prescribes every detail in the art of construction science. ${ }^{45}$ (Fig. 15 a) Following the rules of the mandala ensures balance and harmony in the space to be constructed.

Specific descriptions on how to construct sacred spaces are prevalent throughout scriptures both in the east and west alluding to the idea that the supreme being will dwell in a perfectly proportioned space. Barrie suggests that the precise geometrical construction techniques used in sacred architecture give this building type historical continuity and authority. ${ }^{46}$ In contemporary context, an ordered space can insinuate a calm atmosphere allowing one to transcend reality. Architect Richard Padovan believes that certain proportioning systems such as the golden section, the Fibonacci series, and geometric and harmonic relationships of the
Renaissance era, successfully create sacred spaces which can be experienced universally. $\mathrm{He}$ specifically states;

"architecture provides the satisfaction of a higher existential need: to perceive and to know the world and make it our own by giving it measure". ${ }^{48}$ (Fig. 15 b)

Through geometric practices, humans have created the physical world to abstract the natural world we perceive, and to express the divine.

\section{LIGHT}

The third condition Barrie discusses in his book is one which in itself is the embodiment of the divine. Similar to the symbolic scale and form of spaces, modulating light can produce 'empathetic feelings ranging from grandeur to insignificance. ${ }^{49}$ Variation of light and dark as one travels through a sequence of spaces can 'serve to underline feelings of progress towards a goal.' Light conveys the intangible or ephemeral elements of the sacred. ${ }^{50}$ Hence, the expression of light in sacred spaces should aspire to emanate enchanting qualities.

"Sacred architecture is a vessel that holds both light and shadow and the strategic placement of openings focuses perception and suggests movement inside its spaces ... special quality of light symbolised God and was believed to be a medium that could co-join humans with the divine." ${ }^{51}$

Barrie illustrates the significance of light in sacred spaces and how manipulations of light can communicate atmosphere symbolic of the mystical.
${ }^{41}$ Barrie, T. The Sacred ... 136
${ }^{42}$ Barrie, T. The Sacred ... $134-135$
${ }^{43}$ Barrie, T. The Sacred ... 133
${ }^{44}$ Barrie, T. The Sacred ... $132-134$
${ }^{45}$ Michell, G. $71-79$
${ }^{51}$ Barrie, T. The Sacred ... 209
${ }^{50}$ Barrie, T. The Sacred ... 45
${ }^{46}$ Barrie, T. The Sacred ... $132-134$
${ }^{48}$ Pandovan, R. 15
${ }^{47}$ Barrie, T. The Sacred ... 136 


\section{MATERIALITY}

This spatial condition in sacred architecture is not as prominent as light and geometry. Nevertheless it is considered to be imperative for the case of typological continuity and coherence. Barrie writes how the use of materials in architecture can influence the way in which the space is experienced and can improve and enrich the lives of the inhabitants. ${ }^{52}$ Sensory interaction with surfaces invoke energising qualities. Order and coherence of materials engender calming qualities. ${ }^{53}$ The specificity of material types are not discussed in depth in Barrie's literature as it is more appropriate to address why certain surfaces are used and how they are perceived in sacred spaces. Time and place validate material choices but application of these materials convey authenticity and symbolic continuity of the building. ${ }^{54}$ The way in which materials will be used in the context of this thesis is important for me to explore in the design process as it will influence the sacred experience of the space.

${ }^{52}$ Barrie, T. The Sacred ... 220

${ }^{53}$ Barrie, T. The Sacred ... 221

${ }^{54}$ Barrie, T. The Sacred ... 216

${ }^{55}$ Benedikt, M. $32-56$

${ }^{56}$ Barrie, T. The Sacred ... $214-217$

${ }^{57}$ Barrie, T. The Sacred ... $214-217$

${ }^{58}$ Barrie, T. The Sacred ... $217-218$
Sacred architecture lends itself to be more authentic and genuine than other building typologies as it is embedded in cultural and religious foundations. Professor Michael Benedikt discusses how context brings authenticity to architecture and how 'realness' can be achieved. Architecture must be self-aware, engage us directly instead of referencing, and provide 'something ephemeral beyond the confines of program and site.' ${ }^{55}$ By understanding architecture of the past as well as contemporary, we can engage in a more authentic means of design.

Barrie concludes on the point of authenticity and questions the need for physical space in order to enhance our spiritual self. ${ }^{56}$ Sacred architecture is employed by material means but it leads to an immaterial outcome. The mystical experience is evidently not dependent on architectural setting, rather transcending the external environment and progressing inwards. Nevertheless, the need to establish a sacred space arises as it is the first step in the spiritual path. ${ }^{57}$ The physical presence of the sacred leads to internal realisation of the sacred. ${ }^{58}$ This statement is most meaningful for this thesis and justifies the initial aims and objectives. Sacred architecture is indeed a successful mediator between humans and the divine and thus is the fundamental perspective of this thesis.

3.4 Common Spatial Qualities - Architecture of the FIVE religions

Extensive analysis of Barrie's literature and spatial conditions led to developing a matrix of architecture both contemporary and historical of the five main religions. The following pages display a architectural examples of both contemporary and classical religious spaces. These are categorised into dominant qualities of Proportion, Light and Geometry. (Fig. 16) 


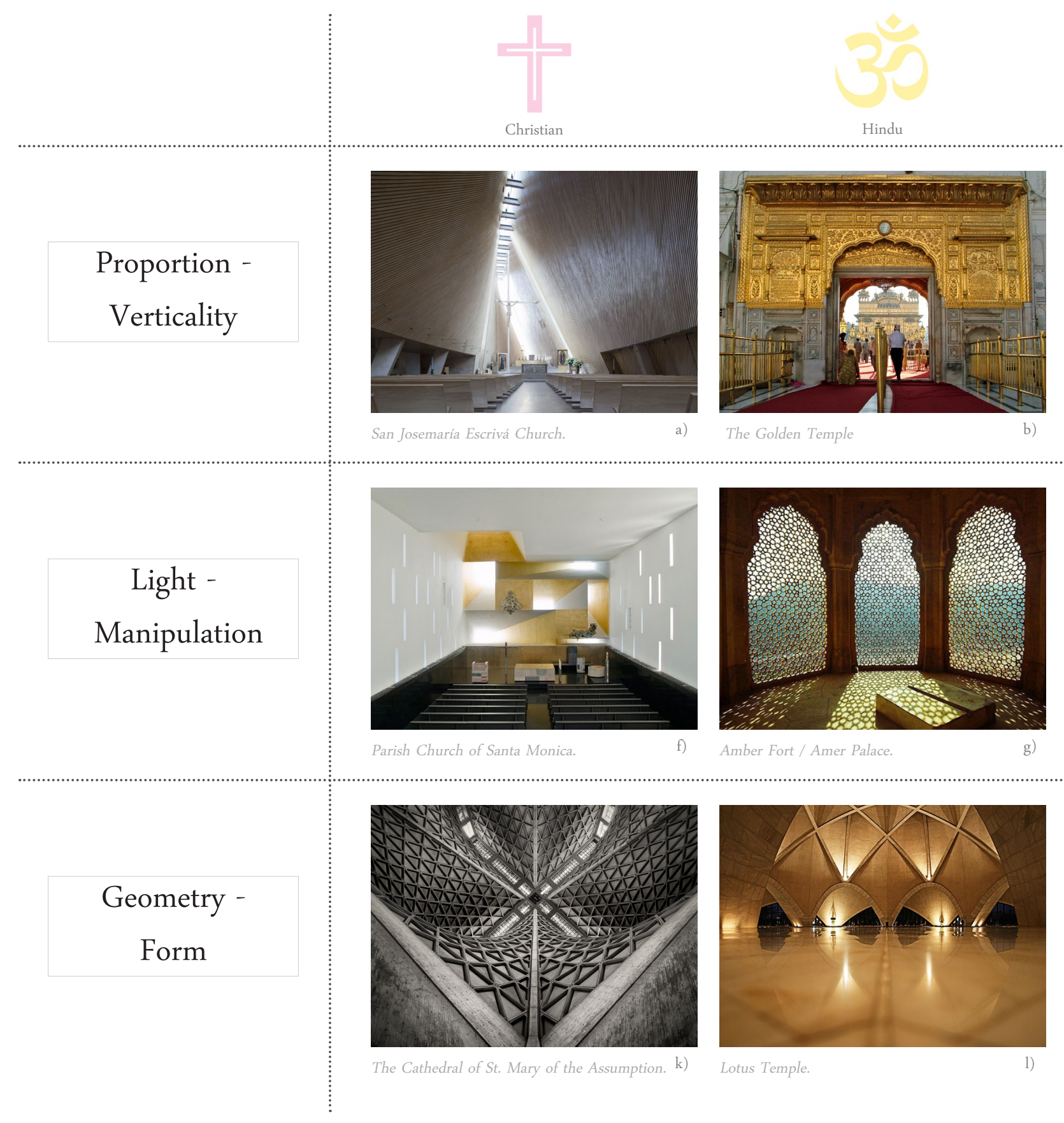

Figure 16) Matrix of Architectural Examples found within the Five Religions namely Christianity, Hinduism, Buddhism, Islam and Judaism. These examples share common spatial qualities which express spiritual atmosphere. 


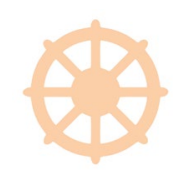

Buddhist

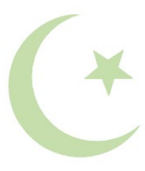

Muslim

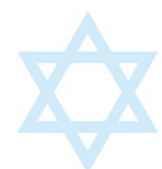

Jewish
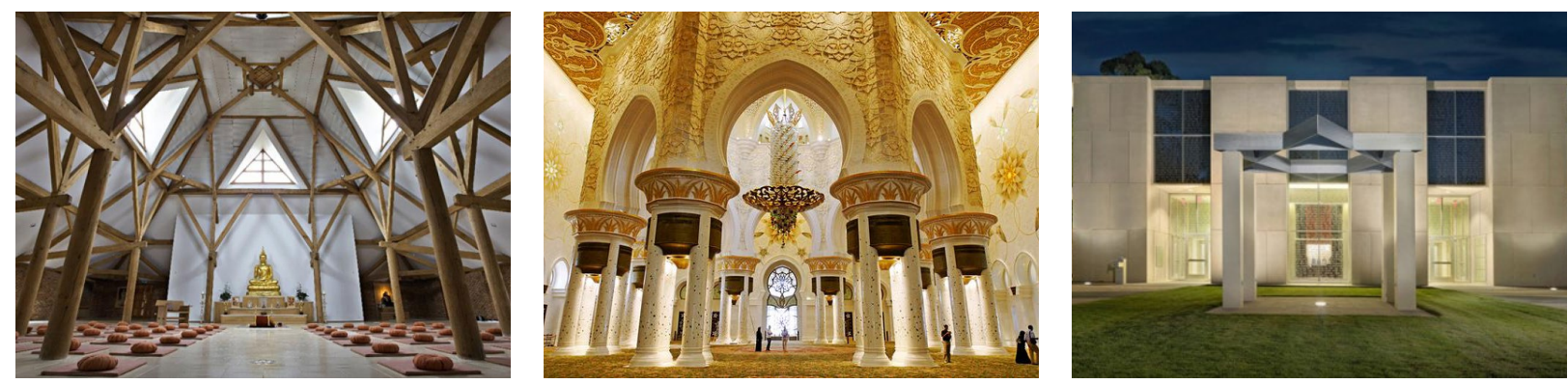

Sheikh Zayed Mosque.

Beth El Synagogue.

e)
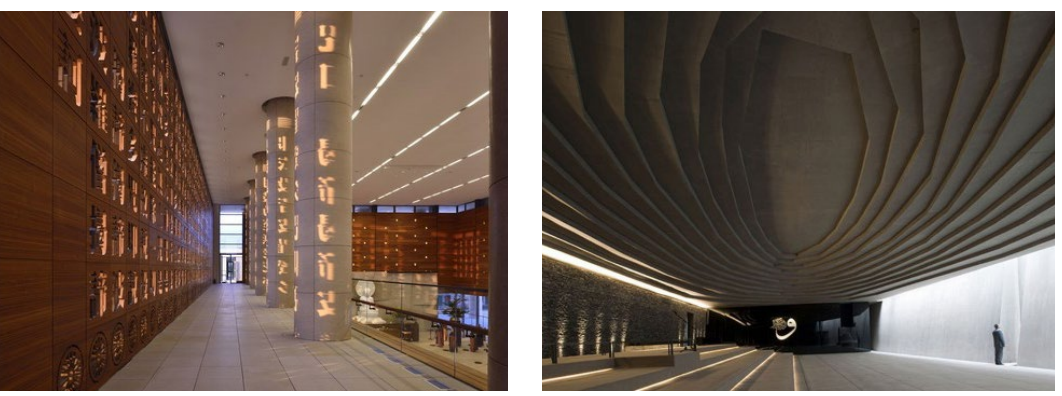

Water-Moon Monastery

Sancaklar Mosque.

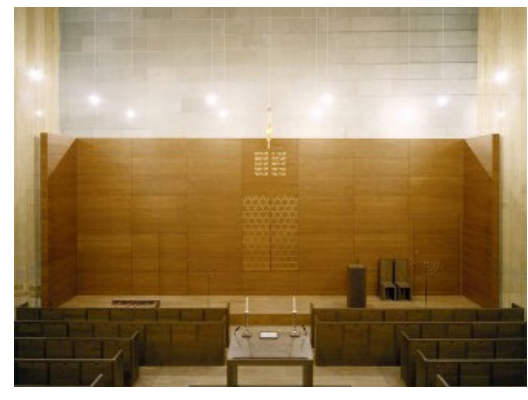

New Synagogue Dresden.
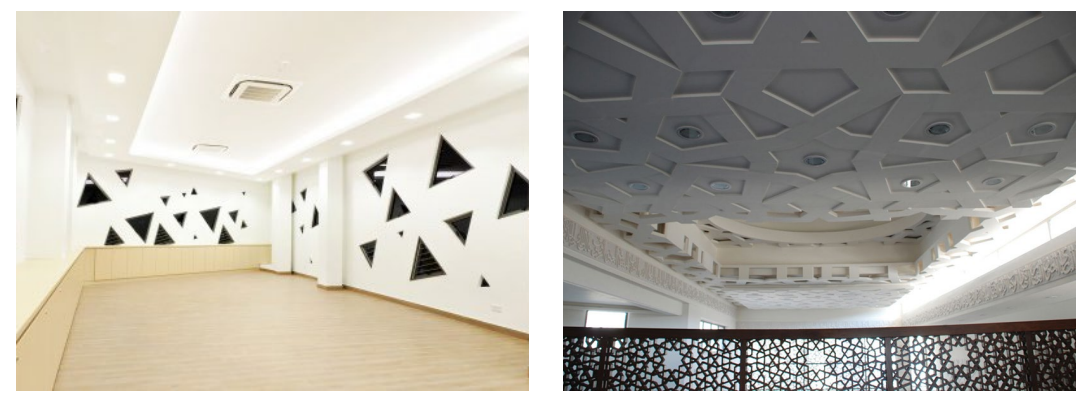

Al Rawda Mosque.

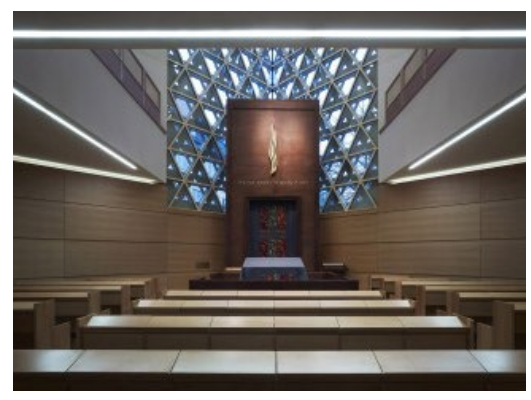

Ulm Synagogue. 
3.5 The Case for Contemporary Sacred

Architecture

"Every so often there is a compelling need for sacred space even within the everyday life, an incontrovertible [undeniable] necessity that has been confirmed over the centuries by sublime examples, and that has now re-emerged decisively, perhaps in an extreme attempt to respond to the incompleteness of the contemporary dimension"

- Mario Botta "Sacred Space" in Architetture Del Sacro: Prayers in Stone.

As discussed in the analysis of The Sacred Inbetween, sacred architecture is evidently a mediator between people and their higher-selves. The underlying question this thesis argues is the need for a sacred building in a contemporary context. Constructing the Ineffable is a compiled book of essays written by prominent architects and scholars as a response to Le Corbusier's discourse on 'Ineffable Space.' Karsten Harries, Karla Britton and Mirsolav Volf are a few key authors among others who present the case for sacred architecture in today's contemporary world.
Georg Wilhem Friederich Hegel states;

"Architecture is, in fact, the first pioneer on the highway toward the adequate realisation of the Godhead ... it in short reveals the will this to assemble, and although under an external relation, yet in agreement with the principle of art." 60

The relevance of sacred in the contemporary world is explored by Yale University Professor Karsten Harries. He claims that the 'sacred needs architecture if it is not to wither, and similarly architecture needs the sacred'. ${ }^{61}$ The reason spirituality has fleeted from the modern world is that it is difficult to comprehend it in a rational manner. Advances in technology and science have induced this way of comprehension. Consequently, modernity has reduced religious practices and constructing the architecture which serves them, ergo the significance of the sacred is lost. According to Harries, what makes something 'sacred' is when it is given value and significance. As for architecture the issue arises with relationship of aesthetic to the sacred. ${ }^{62}$

Harries references German-British Scholar Nikolaus Pevsner's infamous saying; "a bicycle shed is a building, Lincoln cathedral is a piece of architecture". ${ }^{63}$ (Fig. 17) Harries interprets this as 'works of architecture equal building plus aesthetic component'. Despite this rule to 'great' architecture, he writes how modern buildings often have a 'weak identity'. Critiquing Santiago Calatrava's turning torso, which is to be reproduced in Las Vegas and Istanbul, he says that it does not engage with its surrounding context. (Fig. 18) He explains how the same aesthetic of the building can be replicated but the architecture is removed of meaning as the building does not respond to its existing environment or remember the 'special history of that place'. ${ }^{64}$ 
Editor Karla Britton similarly suggests that the experience of sacred space is not just dependent on its material construction but the value which people bestow upon it, referring New York city's 9/11 memorial site. ${ }^{65}$ The Memorial is designed to express a narrative journey beginning with grief of the 'fallen' and ending with hope. (Fig. 19)

Harries explains the relationship between the sacred and history by quoting German Jewish philosopher Walter Benjamin. "Sacred depends on history and memory, to experience architecture as sacred is to experience it as possessing an aura of transcendence." ${ }^{66}$ The loss of aura in modern buildings is believed by Benjamin to be because they often don't have a sense of belonging to a particular geographical or historical context.

Contemporary theologian Miroslav Volf views this topic in a parallel light to Benjamin and Harries. He says that 'sacred memory defines identity'. ${ }^{67}$ (Fig. 20) Volf elaborates that individuals receive sacred memories from communities instead of directly experiencing the spiritual for themselves. If communities can gather in a particular place, the architecture becomes a site of sacred memories. Volf describes how people in today's society want to live 'experientially satisfying lives' but we are cut off from the eternal truth so we have no connection to transcendence. ${ }^{68}$ As Barrie equally claims, Architecture has the ability to reconnect us to our innate condition. ${ }^{69}$

Harries discusses that humans have always had the urge to decorate and demanded more of their dwellings. He reveals that we demand objects to provide not just the body, but the soul with shelter. ${ }^{70}$ Sacred architecture should not just provide for the body, but for the whole human being, with shelter. Instrumental thinking or aesthetic invention are not capable of providing this. It requires a binding back of aesthetic creativity to the sacred. If architecture does not continue to create spaces for the sacred in contemporary ways, 'the sacred may wither.' ${ }^{71}$

This concluding statement embodies the core ideas of this section, illustrating the direction which sacred architecture should take in contemporary context, in order for it be validated and acknowledged by today's society. Sacred architecture cannot simply be aesthetically beautiful, it needs to possess transcendent qualities. This can be achieved if spatial characteristics can respond to its surrounding context and history and therefore develop into a space of sacred memories meaningful to the community it intends to serves.

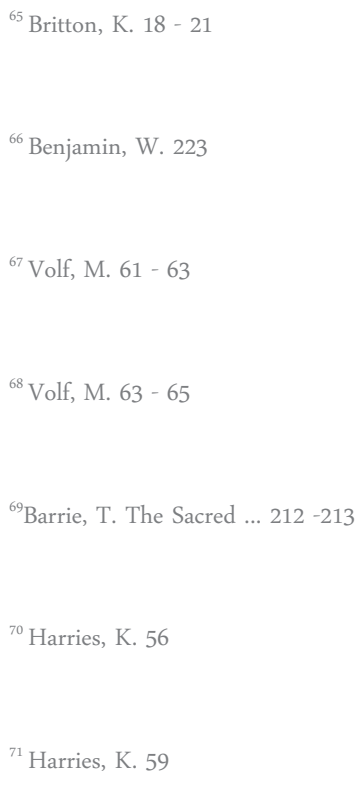



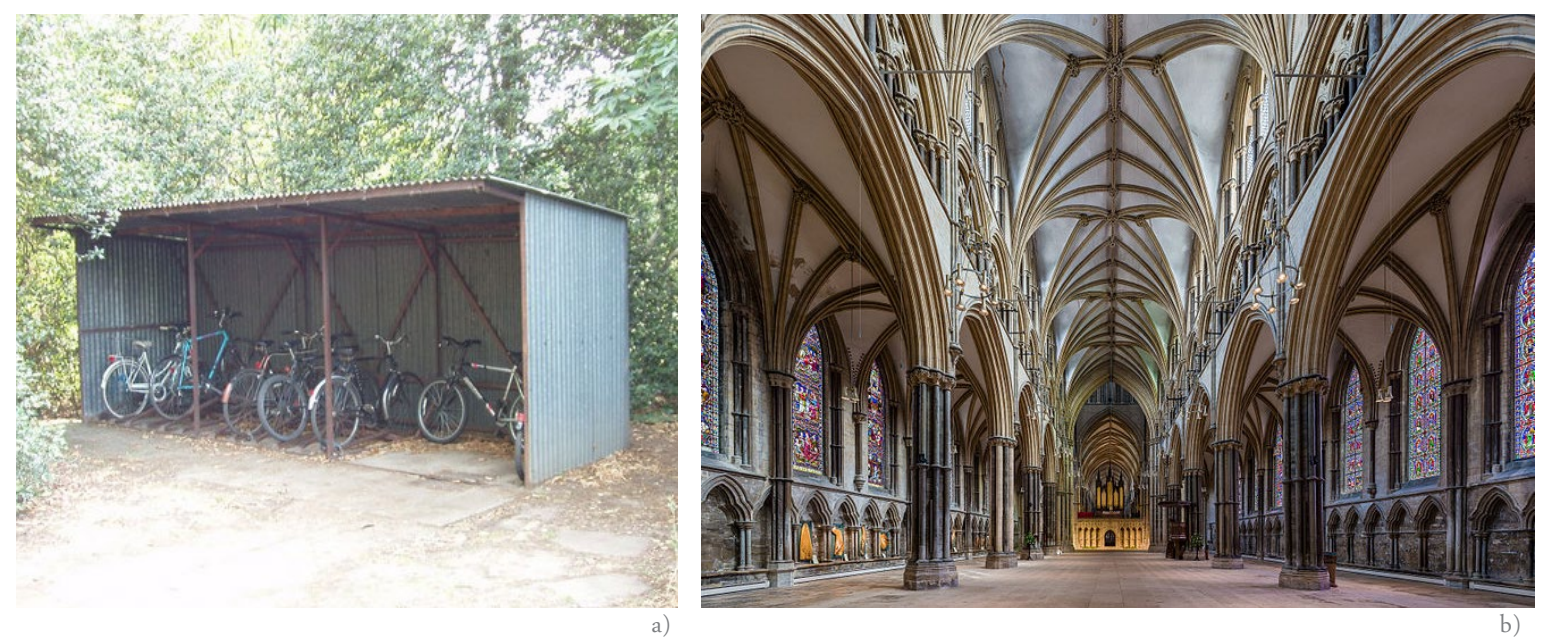

Figure 17) Pevsner's comparison between what he views as a building - Bicycle Shed (a) and what he regards as architecture - Lincoln Cathedral (b)
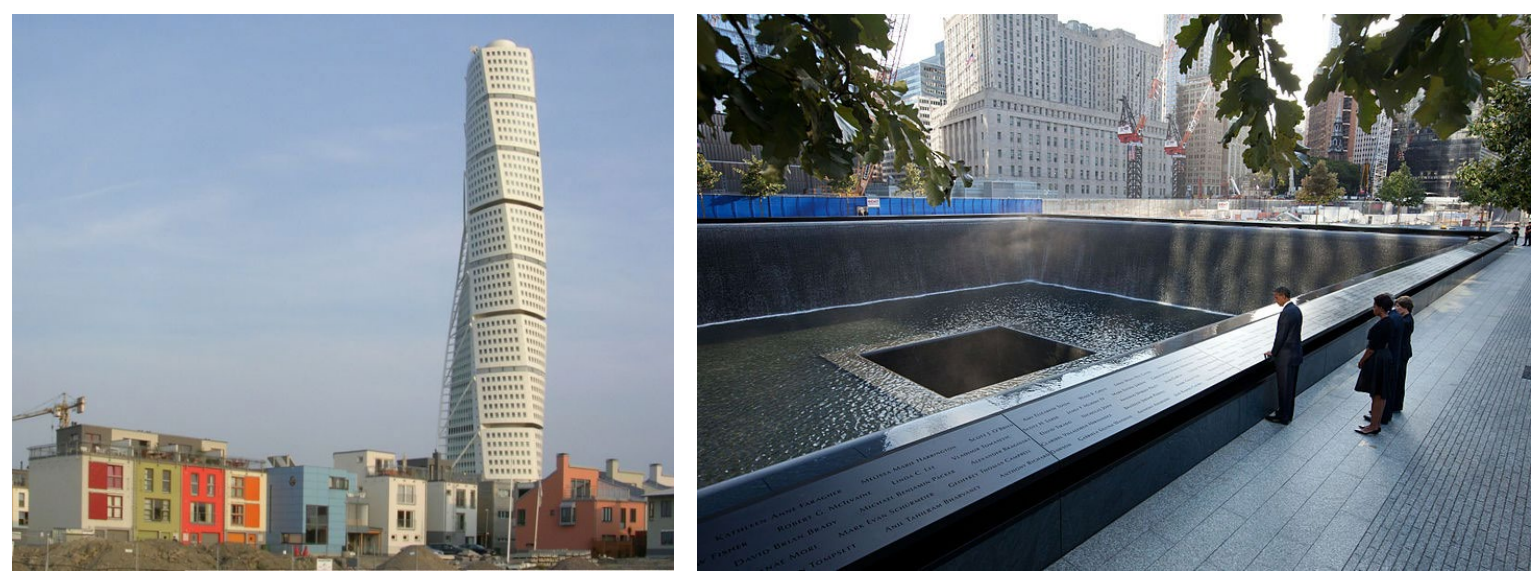

Figure 18) Santiago Calatrava's Turning Torso in its surrounding context, Malmo Sweden

Figure 19) President Obama visiting the 911 Memorial in NYC. The Memorial site is sacred as it was built on the site where old Twin Towers stood before the attack

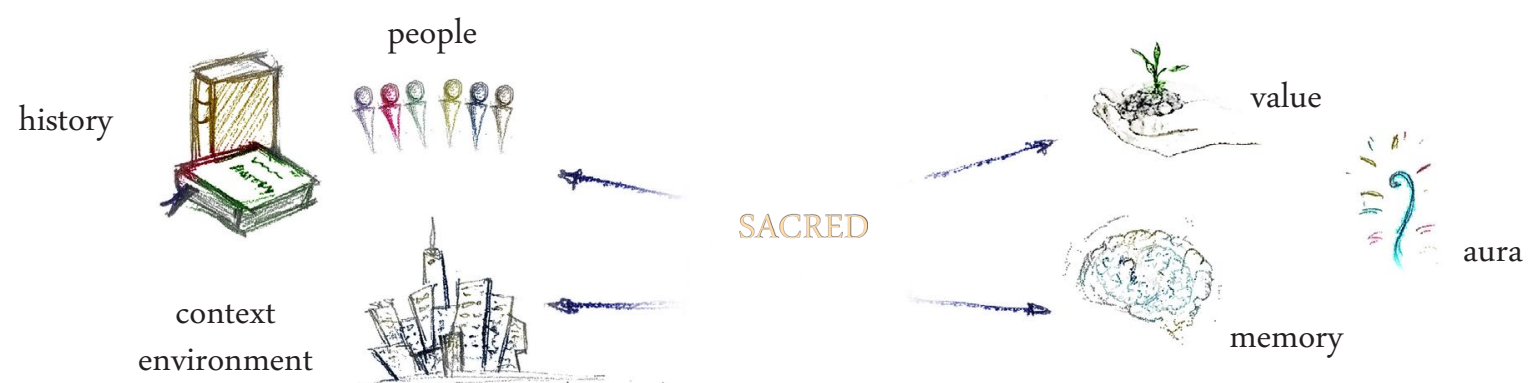


3.6 Conclusion - The Need for Contemporary

Sacred Space in New Zealand

The topic of this thesis demands explicit investigation of theory to understand how the design can resolve the issue being dealt with. The seemingly simple question of this research involves thorough investigation; firstly the change in the role of religion and what it means for the contemporary age. Next the subject of universality, requiring analysis of the essence of spirituality in the east and the west. This is followed by looking at the connection between religion and architecture, and the spatial qualities which architecture tends to exhibit in order for it to be experienced sacred. Lastly justifying of the relevancy of my thesis by analysing why sacred architecture is needed in the contemporary world. The outcome of this analysis provides a framework for design approaches to bring sacred architecture back into contemporary awareness and society. For the sake of this thesis, New Zealand presents an opportunity to explore design manifestations. The country is advanced in science and technology, and is continuously increasing in social diversity. To create a design intervention which seeks to embrace the multi-culture society, mediate people with the divine and therefore attend to the innate desire for ultimate happiness, and reconnect to history and sacred qualities of the site, is the fundamental aspiration and intention of my research thesis. 
CHAPTER FOUR 


\section{THE SACRED SITE}

\subsection{Introduction}

This chapter examines an extensive analysis of the proposed site where the design experiments will be tested. The intention for this research is to be site specific so in-depth analysis is necessary in order to understand the need for Sacred Architecture in New Zealand. This section will review how the design can effectively interact with the site conditions and how the site can communicate sacred qualities specifically meaningful to New Zealand's heritage and diverse culture.

4.1 Why New Zealand?

In world history, New Zealand is considered a young country as it was one of the last remaining land mass to be inhabited by humans. The most recent research confirms that Maori of Polynesian decent settled in New Zealand during the 13th Century. After the British colonised New Zealand in the 1800's, migrants from all over the world started to settle in this new peaceful land of opportunities.

New Zealand has always been a place fluctuating with immigrants, however in the last decade, the country has seen the biggest influx of people of different cultures and traditions. According to New Zealand Census Statistics, the number of Asians living in New Zealand had an increase of 98\% from 2001 to 2013. The number of Middle Eastern, Latin American and African (MELAA) people also significantly increased from 2001 to 2013 by $88 \%$.
Buddhism and Sikhism have either doubled in numbers or increased considerably, coinciding with the trend of ethnic group population. (Fig. 21 and App. 1)

This rise in ethnic diversity has prompted the nature of New Zealand citizens to be accepting of others and their beliefs.

In New Zealand there are many beautiful contemporary communal spaces for secular activities, however there is a noticeable absence of sacred spaces where anyone from any belief can come to grow in their spiritual journey without judgement. Thus, in a country which is advancing in a materialistic sense through technology and science, there is a need for such space so that we can get back in touch with our innate spiritual self.

\subsubsection{Why Wellington?}

The 'city' is universally seen as a collection of various types of people with a range of different backgrounds and values. There is also a strong presence of contemporary architecture within cities which support the city in its growth. These two aspects are critically relevant to this thesis research. (Fig. 22)

Wellington is becoming progressively. Despite being prominently secular and cosmopolitan, the city has a certain spiritual atmosphere. A recent article in the New Zealand Herald conducted a series of impromptu interviews with residents of the city and found that Wellington indeed has a sense of spirituality even though it is the least religious city in New Zealand. The article suggests that people find Wellington to be accepting and tolerant of others instead of challenging them for their beliefs. ${ }^{3}$ Hence, Wellington is an ideal setting for this experiment, as it is exemplary of 
New Zealand ways of acceptance. This site will enable the objective of this thesis which is to bring people from different faiths together, and to grow spiritually.

Wellington has many beautiful, historic religious buildings, but there are not many contemporary examples. One could argue that there are many parks and landscapes in Wellington which can be experienced as spiritual therefore we do not need to create a building in order to venture inwards. Nevertheless, one of concepts of religious space is that it is a stepping stone in the path of spirituality. This need for physical manifestation of sacred space is analysed in literature of Barrie and Harries.

Consequently, the potential opportunity for a public interior which allows all people, religious or atheist, to congregate and connect to their higher self would be beneficial to the city's rise in diverse ethnicities as well as the development in contemporary architectural interventions.

4.2 Sacred within the City - How I chose the Site Selecting an appropriate site within the city to test the grounds of this experiment is crucial for this thesis.

The criteria for site selection is as follows:

1) Within the city or in close proximity

2) Easily accessible and visible by anyone

3) Value and significance of history. i.e. not an arbitrary site

Firstly, I looked at the numerous empty buildings in the city, however these spaces are often suited to retail, hospitality or corporate programme, expressing materialistic atmosphere. I also looked at nooks within the city which could create interesting interior spaces, but they were not obvious enough for the intention of this intervention. I then researched landmarks and parks within the city and came across Te Aro Park as a potential site. Te Aro Park is a great location, sufficing to most of the site selection criteria, yet the site does not present opportunities to create a narrative of journey and pilgrimage, which an influential aspect to this thesis.

4.3 Pilgrimage

There are many ritualistic commonalities among various religions but the act of Pilgrimage has great importance. ${ }^{4}$ It is seen as a journey of spirituality towards a physical shrine or inwards of the soul. This journey is not only significant in religion, but also in secular occasions. An example of this can be seen during ANZAC day commemorations when there is often a procession towards a statue or a cenotaph. The journey through life is something which strikes chord with all of us, religious or not.

An element of the pilgrimage is that it often leads to the highest point in the city or the village. This feature is present in many examples of religious architecture both contemporary and traditional. Le Courbusier's famous Notre Dame du Haut in Ronchamp, is a famous example of a pilgrimage to a place of worship, which could perhaps be seen as a 'pilgrimage for architects'. ${ }^{5}$ Visitors need to venture up a steep hill to get to the chapel and experience the glory of the architecture.

To gain a deeper understanding of the concept of pilgrimage relevant, I read The Pilgrimage by Paulo Coelho. This book is an autobiographical account of the writer himself and his journey to Santiago de Compostela in Spain. Coelho writes about all the things he experiences and learns
${ }^{4}$ Barrie, T. Spiritual Path ... 7

${ }^{5}$ Glynn, S. (2011) 
5 MAIN RELIGIONS IN NEW ZEALAND

(NZ Census 2013 Statistics)

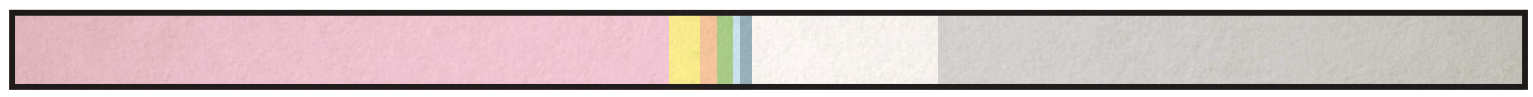

\section{WORLD RELIGION STATISTICS}

(PEW Research Centre 2012 Statistics)

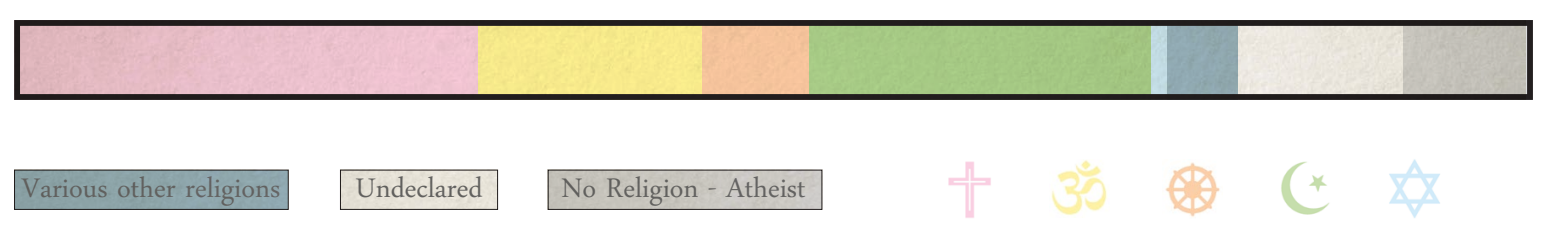

Figure 21) Statistical Graphic, visualising Religion percentages in New Zealand and comparing it to World statistics

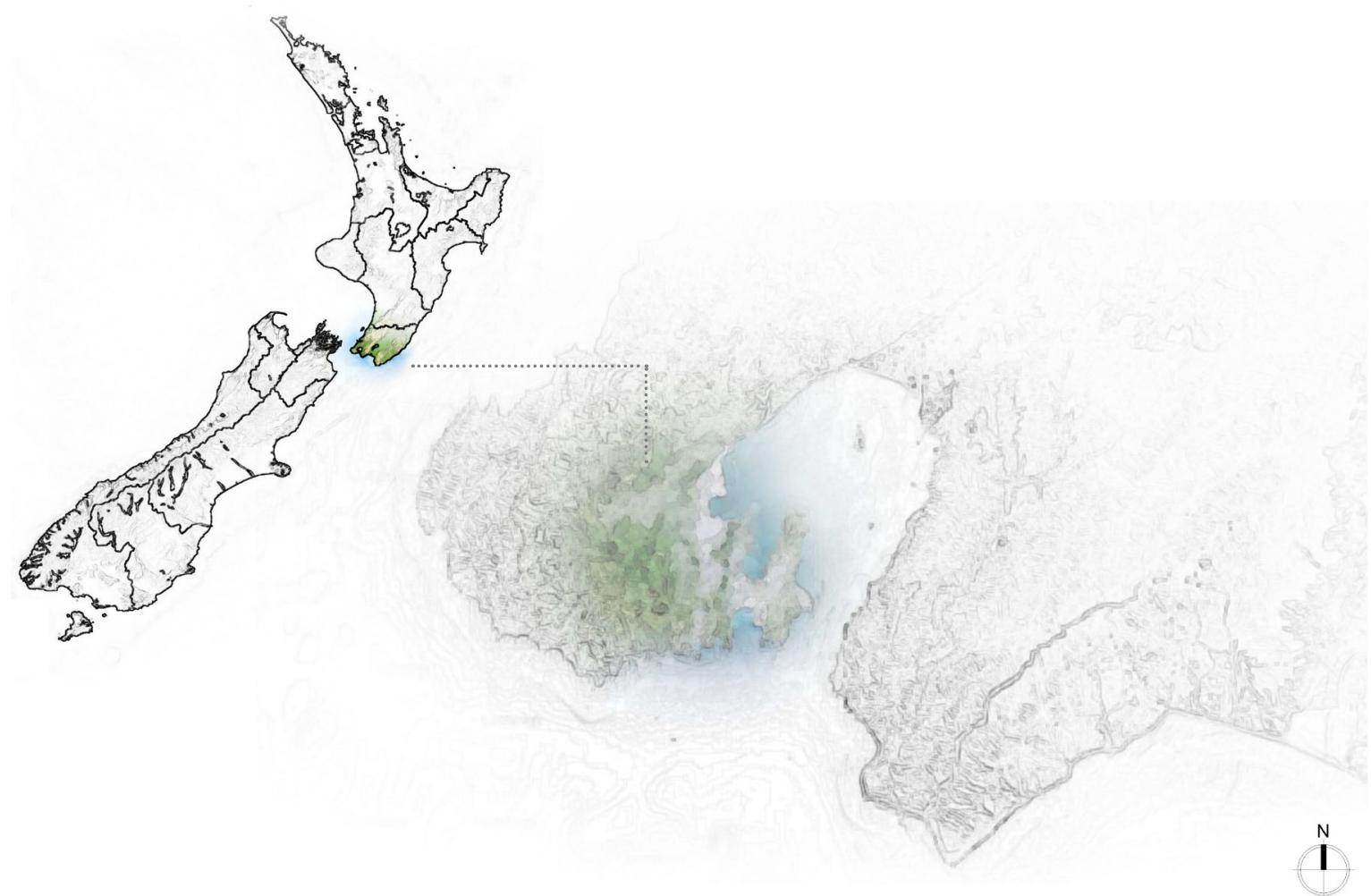

Figure 22) Map New Zealand with close-up view of Wellington City 
along the way in order to find his sword. (App. 2) He explains that different religions and beliefs provide many paths, but the journey itself is what we learn from the most and not what it leads us too. He writes how pilgrimages have 'always been one of the most objective ways of achieving insight.' ${ }^{6}$

Throughout the book, Coelho narrates on fighting the Good Fight. "The Good Fight is the one we fight because our heart asks it of us ... it is the one that is fought in the name of our dreams."

${ }^{7}$ The Good Fight can be interpreted as realising eternal happiness. He further discusses this profound idea in The Alchemist: "to realise one's personal legend is one's only true obligation." 8 This reminds us of the purpose of spirituality; it can be for anyone and does not need to be exclusive to certain religions.

The Pilgrimage in addition to Coelho's infamous novel The Alchemist, reinforce the idea that the act of pilgrimage is indeed essential for spiritual upliftment. It can transform, change and give meaning to one's perception of the world. Although Coelho is regarded lowly by intelligentsia in his home country of Brazil, he is an internationally acclaimed writer as his writings relate to the everyday person and the experiences they go through.
4.3.1 Pilgrimage within Wellington - Mount Victoria

After analysis of Wellington city and with the concept of pilgrimage in mind, the Centennial Lookout on Mount Victoria is a fitting location to test the design. Benefits of this site as a tool for exploring this thesis topic are;

- It is situated within the city therefore easily accessible by everyone, yet it is a calm environment away from the bustling noise of the city.

- The stunning and serene views add to the intention of the proposed programme

- The site reinforces the act of pilgrimage in the journey up the hill

- The Centennial look-out draws many people to stop for a rest from their walks or for contemplation. This automatically suggests that there is an existing sense of peace in this environment which will strengthen the purpose and meaning of the intervention.
${ }^{6}$ Coelho, P. The Pilgrimage. 38

${ }^{7}$ Coelho, P. The Pilgrimage. 61- 62 
4.4 Analysing the Sacred Site

In order to design an intervention which sensitively responds to the existing site of Mount Victoria, relevant analysis is necessary. Investigating the context of the site within Wellington City, the climate conditions, special features of the site and its history will help to gain a deeper understanding of the site and how the intervention will integrate with it. (Fig. 23)

\subsubsection{Contextual}

The precinct of Mount Victoria is in close proximity to the CBD which is the first key point for the site selection criteria. Being close to the $\mathrm{CBD}$ is important because this is where most activity takes place. One of the initial aims of this thesis was to create an intervention within the city so that the one does not need to venture out into the woods to find peace. Marking points on the city map of Surrounding Parks and Landmarks as well as popular Surrounding Places of Worship for each of the religions, reveals that the site is of equidistant from the different locations and therefore makes it an accessible site. (Fig. 24)

Pathways and tracks are also mapped as a way of analysing how people can travel to the site as their own pilgrimage (Fig. 25)

\subsubsection{Climate}

The Centennial look-out point is very much exposed to the elements, especially to Wellington's strong wind conditions. Using Ecotect simulations and inputting the Wellington weather data file from university resources, determined the conditions of the site visualised through a series of sun path and wind rose diagrams. This basic understanding is useful for the design decision

\section{making process.}

\section{SUN}

North orientation in the southern hemisphere evidently maximises sunlight and warmth and this is an important factor to consider when designing. The Sun Path diagrams illustrated in Fig. 26 show the average sun shine and shade during the days of the two solstices and the two equinoxes.

\section{WIND}

Wind the most problematic of weather conditions in Wellington. Seasonal Wind Rose diagrams showing frequency and direction of wind on the site is illustrated in Fig. 27.

\subsubsection{Topography}

Since Mount Victoria is a hilly site, studying the contours and land formation is helpful to the design process. Fig. 28 shows contour maps of the Centennial Lookout point. The proposed site has an exiting old water tank which can be removed for the sake of the design development. ${ }^{9}$ This means that the site can be levelled out according to the design.

\subsubsection{Views of the Site}

The look-out point provides 360 degree views of the city and surrounding suburbs, as well as of Wellington's beautiful harbour. The aim is to enhance or frame these beautiful views so visitors can appreciate the serenity of them and visually connect with the surrounding environment. (Fig. 29 \& Fig. 30)

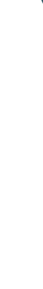


4.4.5 Direction and orientation

Looking at all the different religions and their architecture, one of the important qualities commonly seen is the influence of direction and orientation in both the overall structure and the interior spaces. The proposed site naturally faces north east. Understanding the directions of the site and the existing forms within the site, will be helpful in the spatial arrangement and in turn influence the design holistically. 


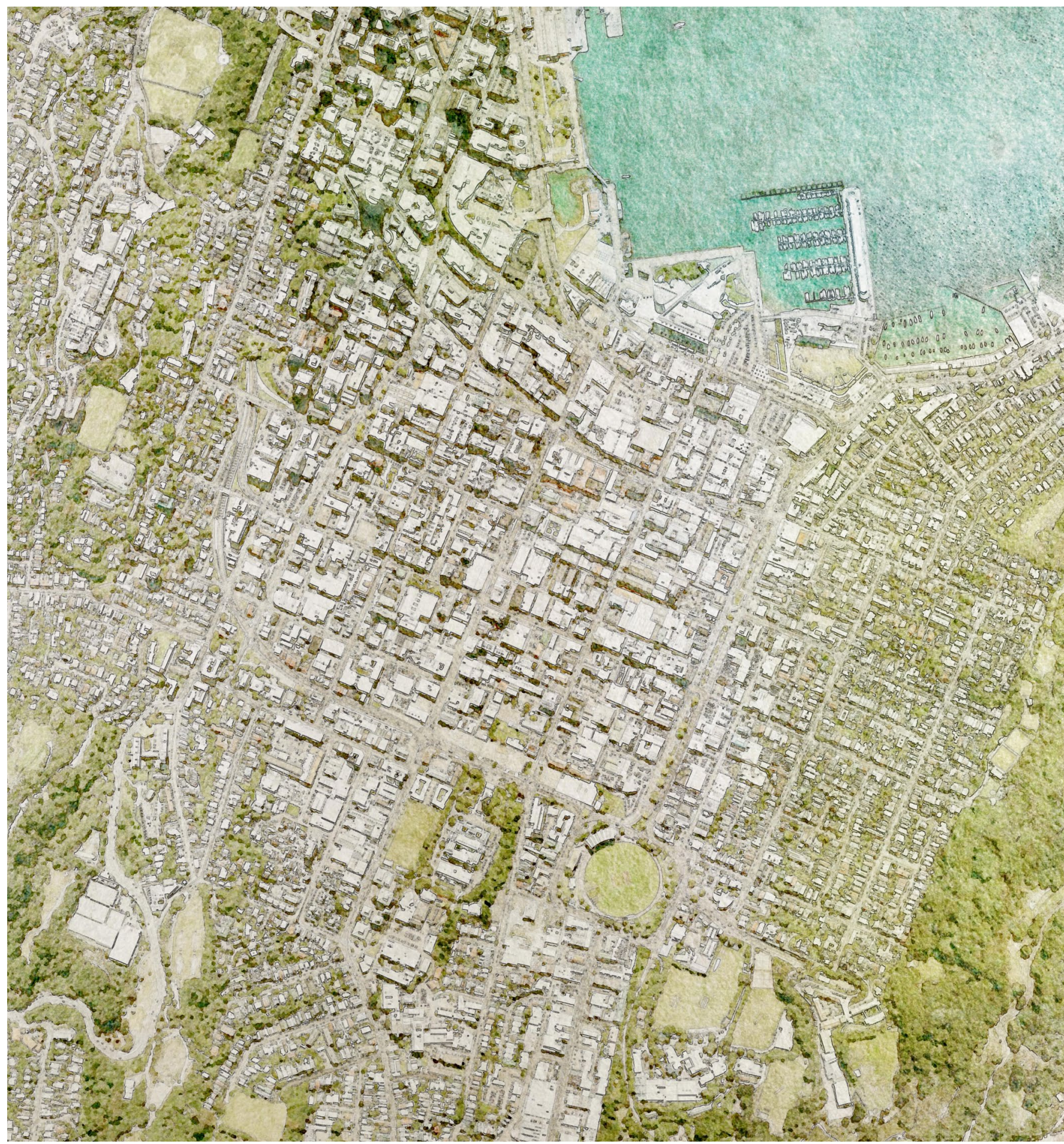

Figure 23) Proposed Site in Mt. Victoria within greater context of Wellington City - Compass illustrating surrounding precincts. 


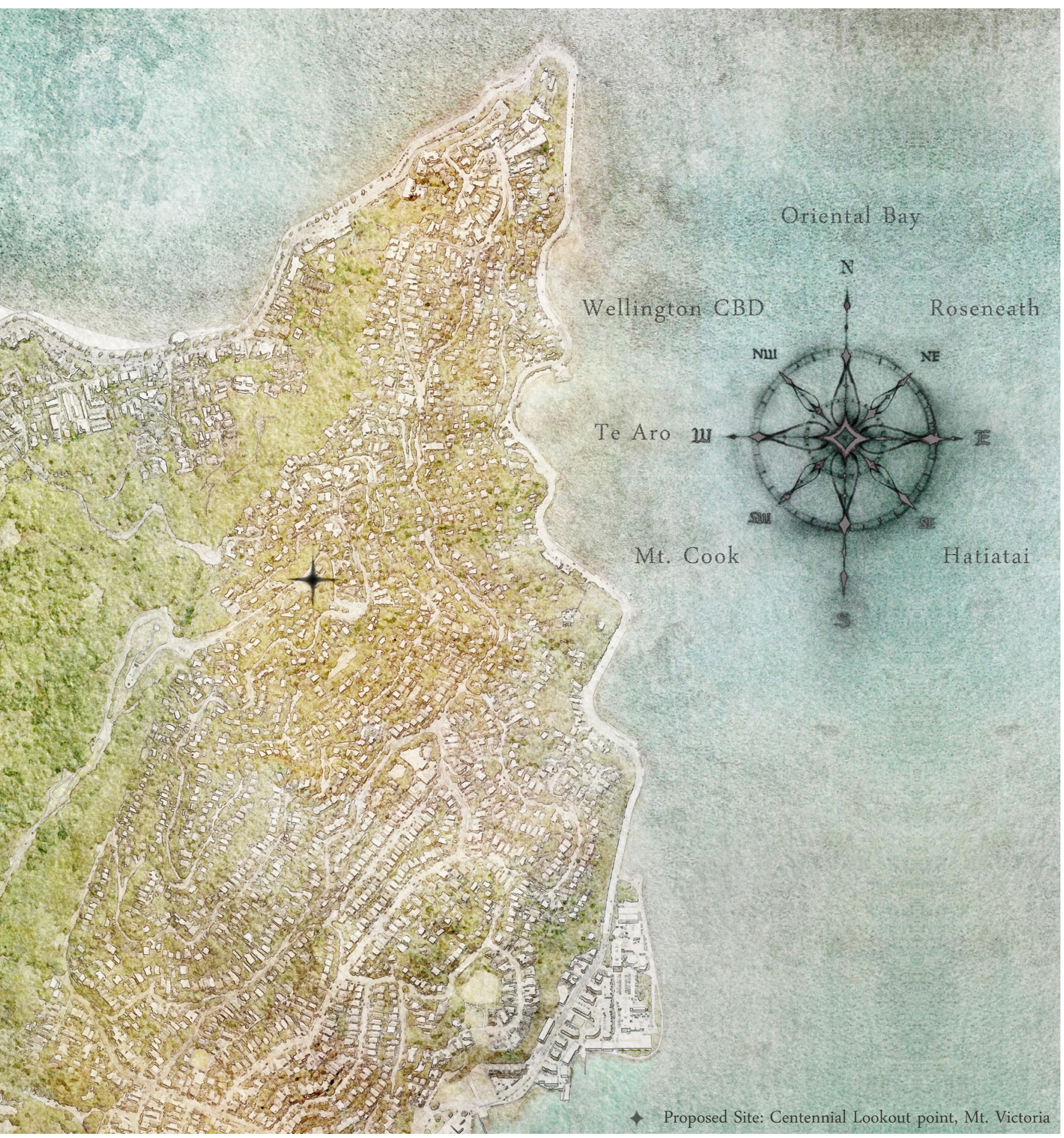




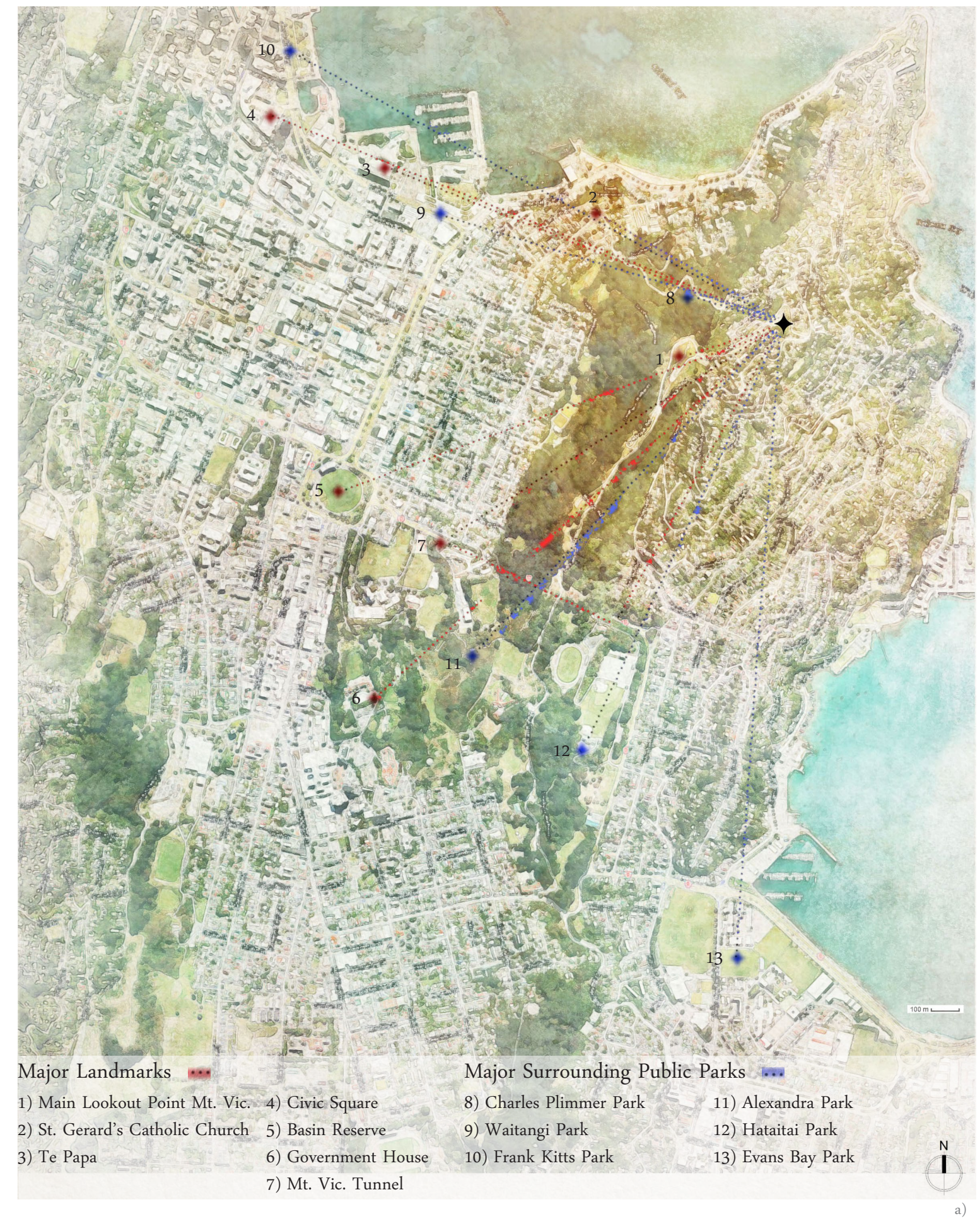

Figure 24 a) Map showing Major Landmarks and Public Parks surrounding Mount Victoria 


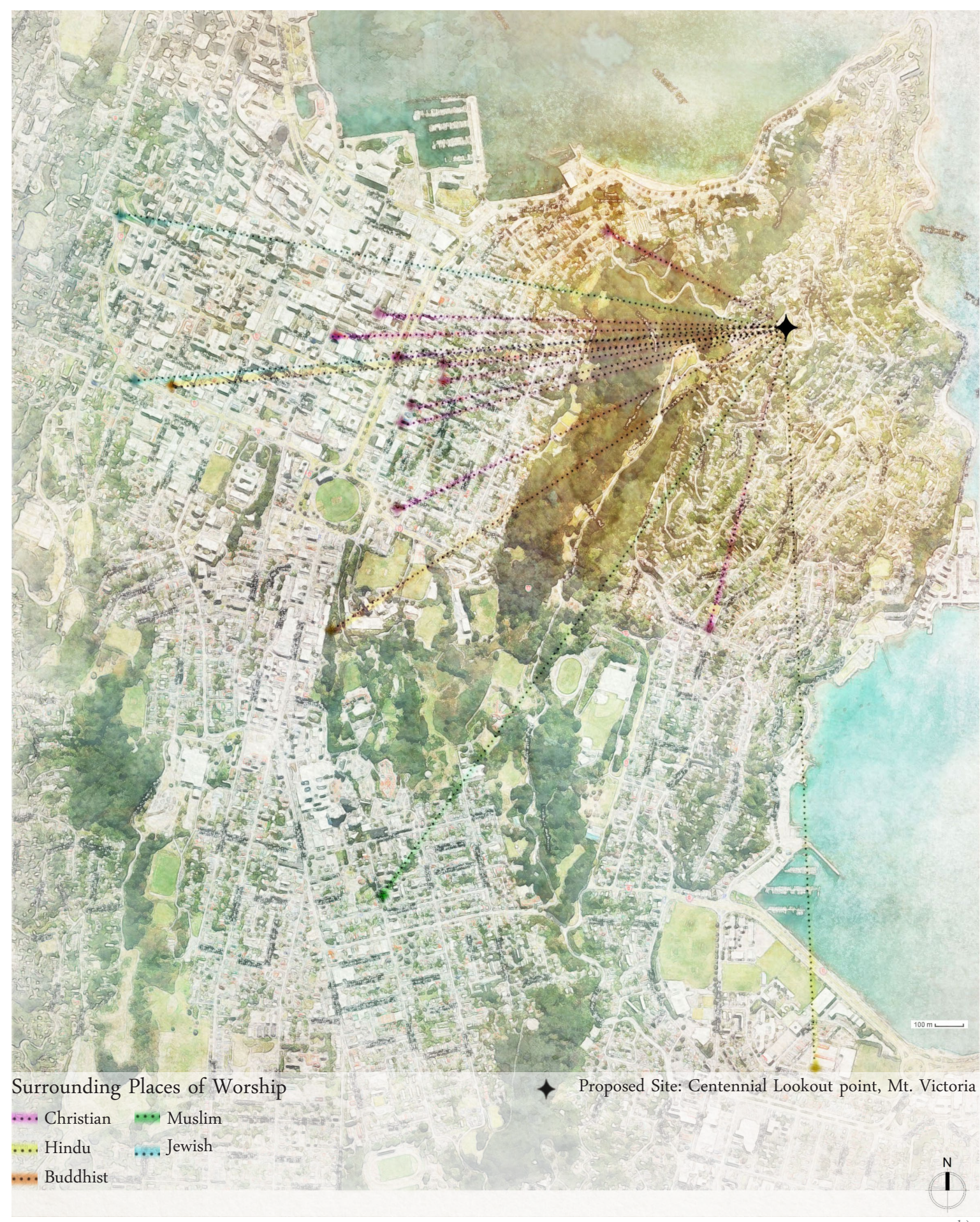

Figure 24 b) Map showing well known Places of Worship within the proximity of Mount Victoria and Wellington City 


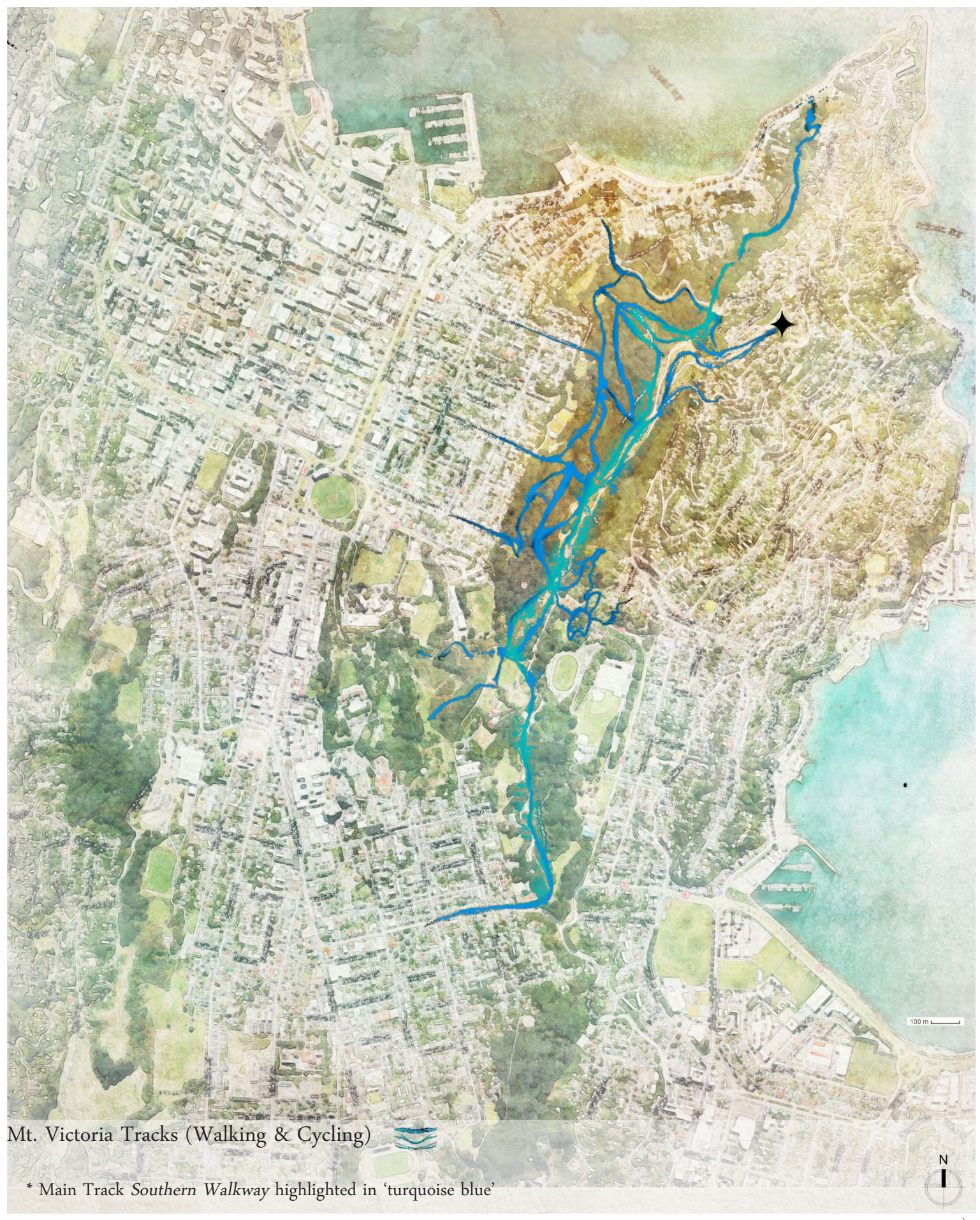

Figure 25 a) Various Tracks leading to the proposed site of the Centennial Look-out point on Mount Victoria 


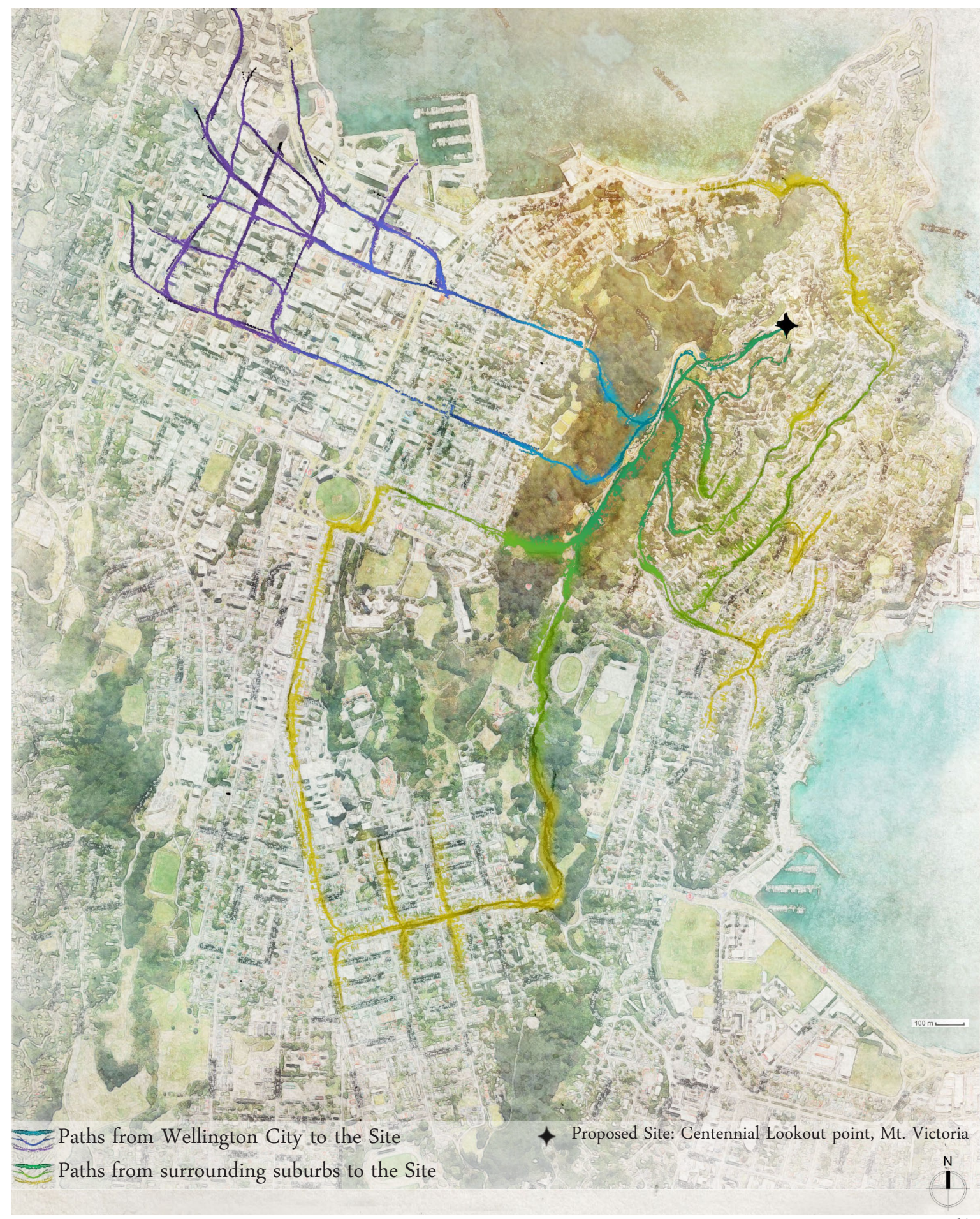

Figure 25 b) Roads and Pathways leading to the site - 'Pilgrimage to Centennial Lookout point Mount Victoria' 

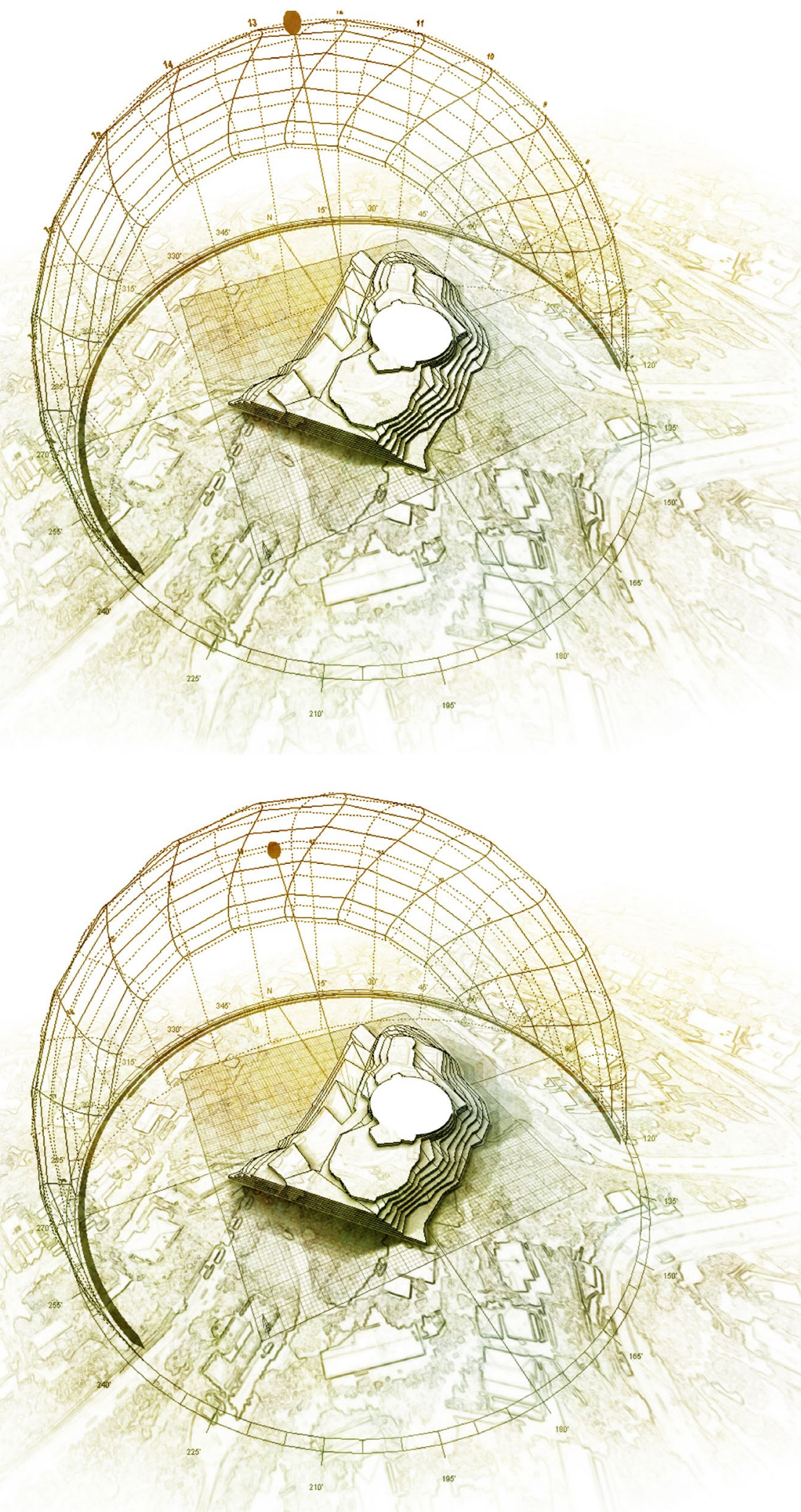

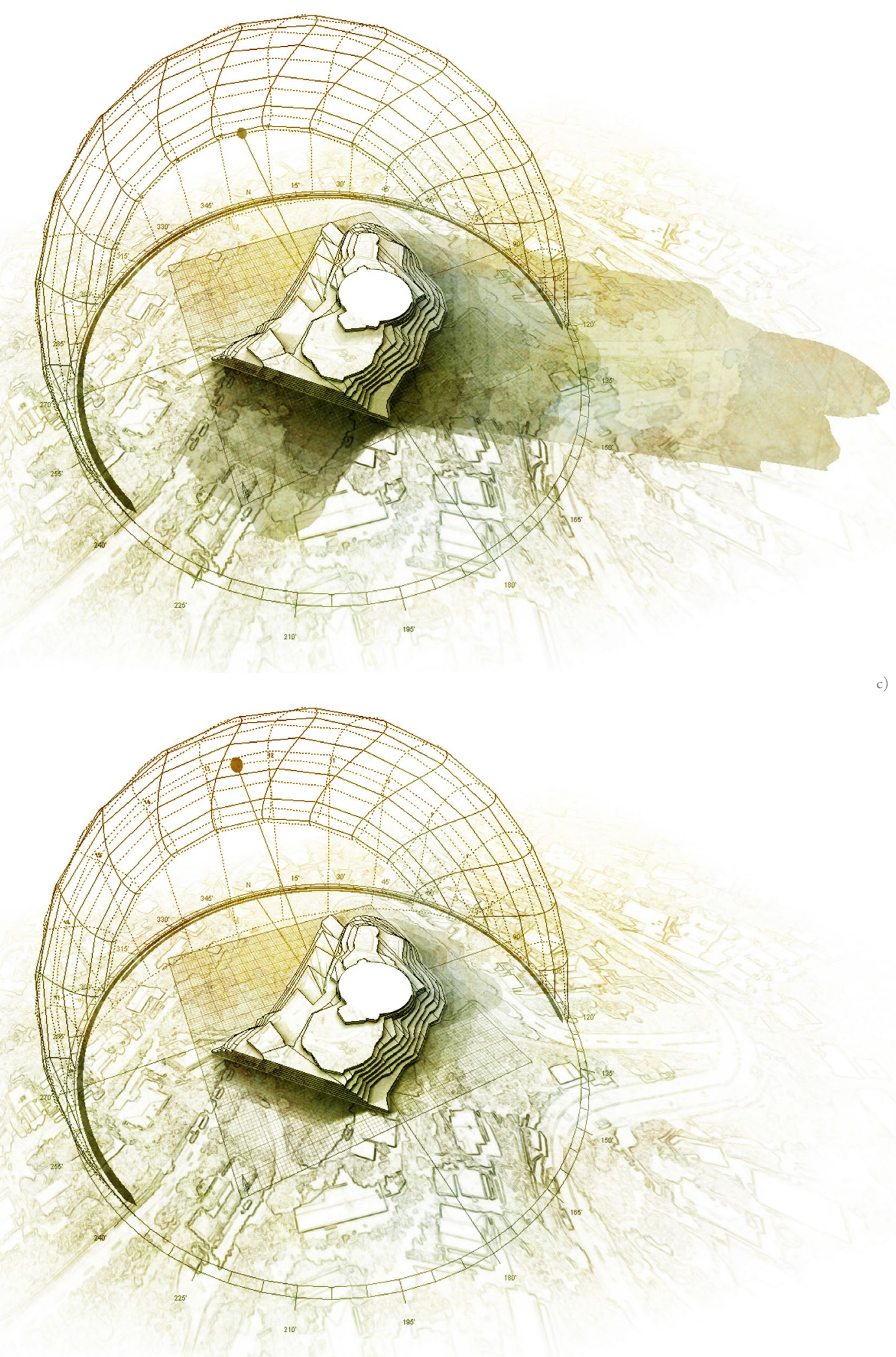

$\overrightarrow{1}$
0
0
0
0
0
0
0
0 

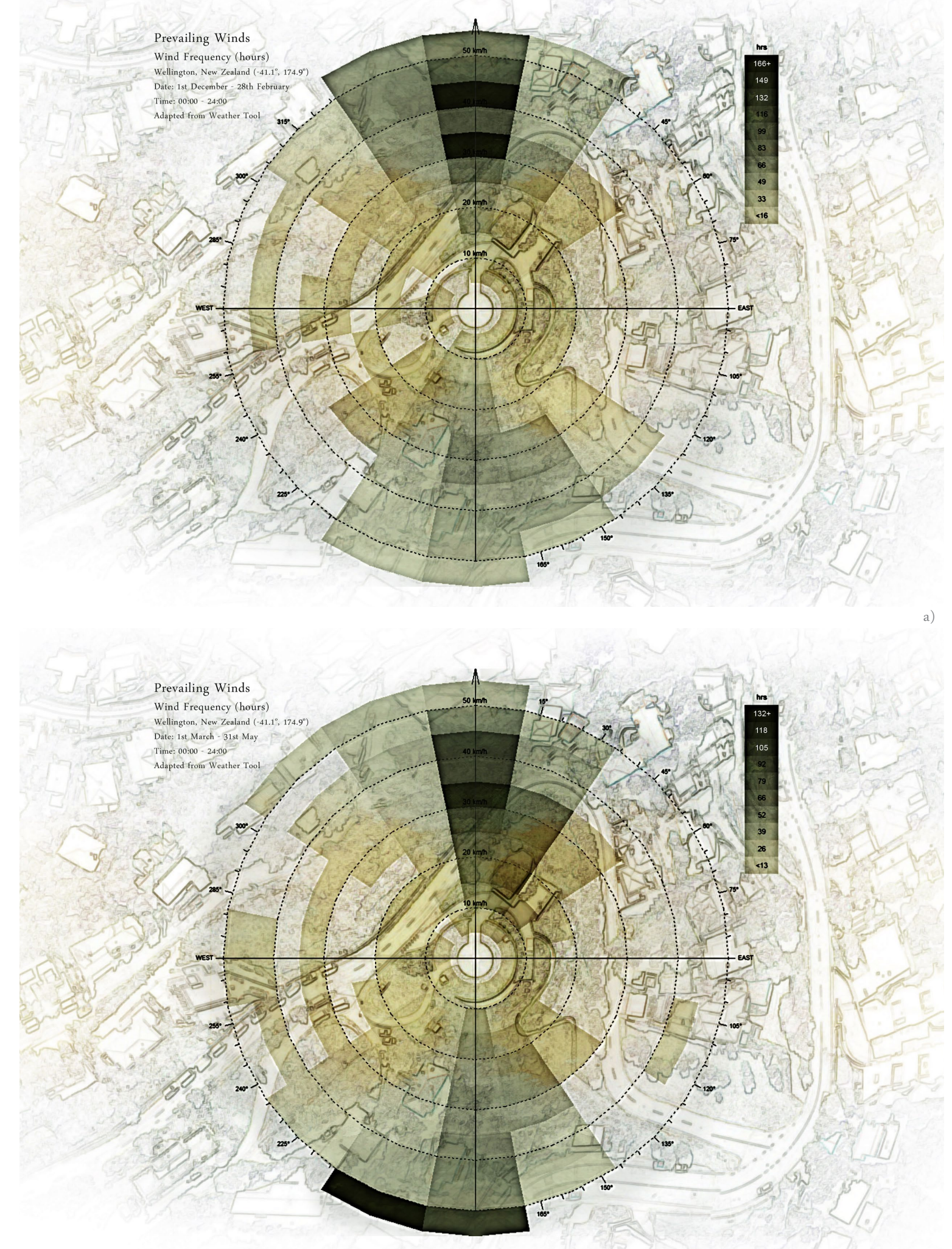

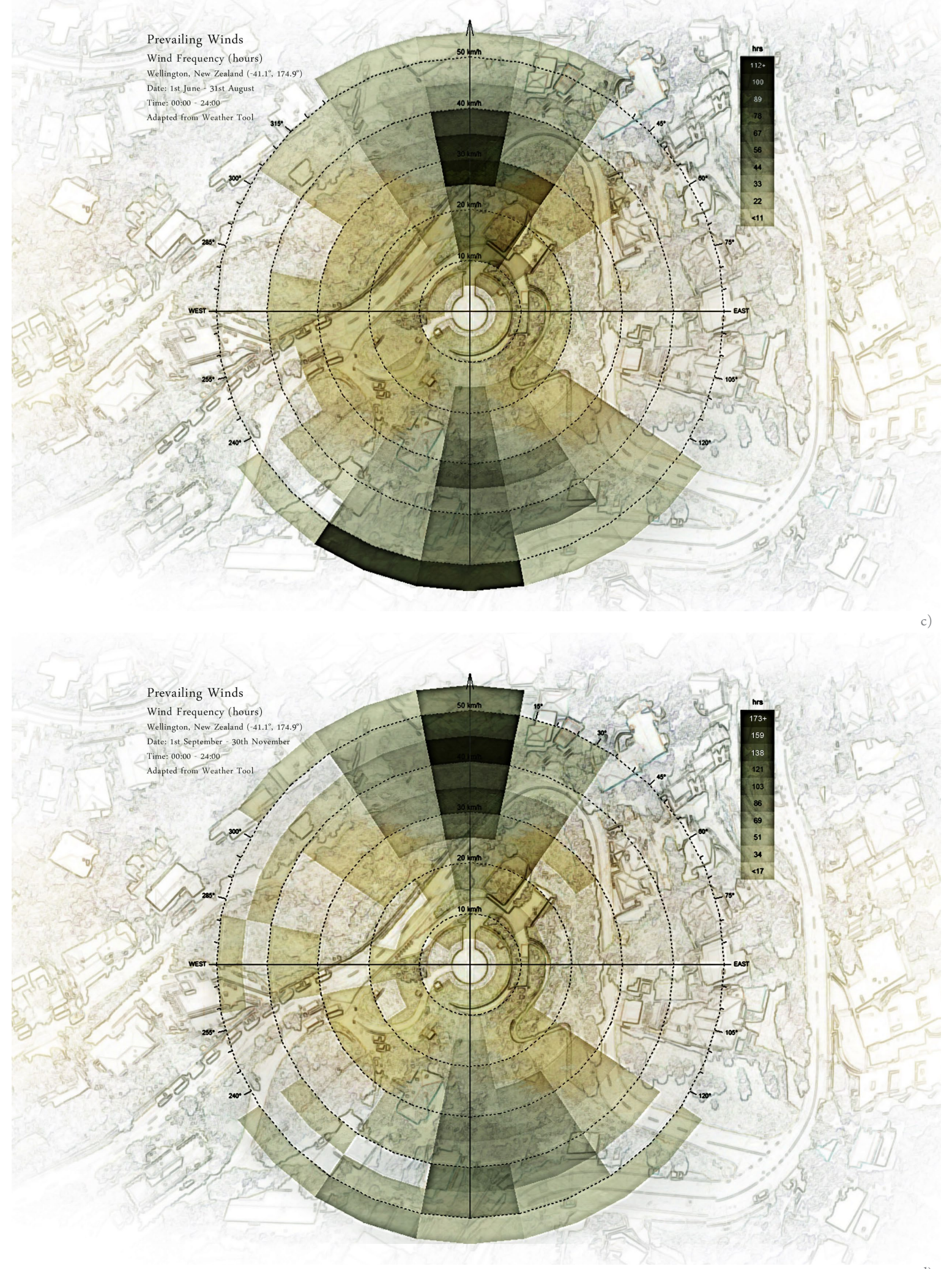


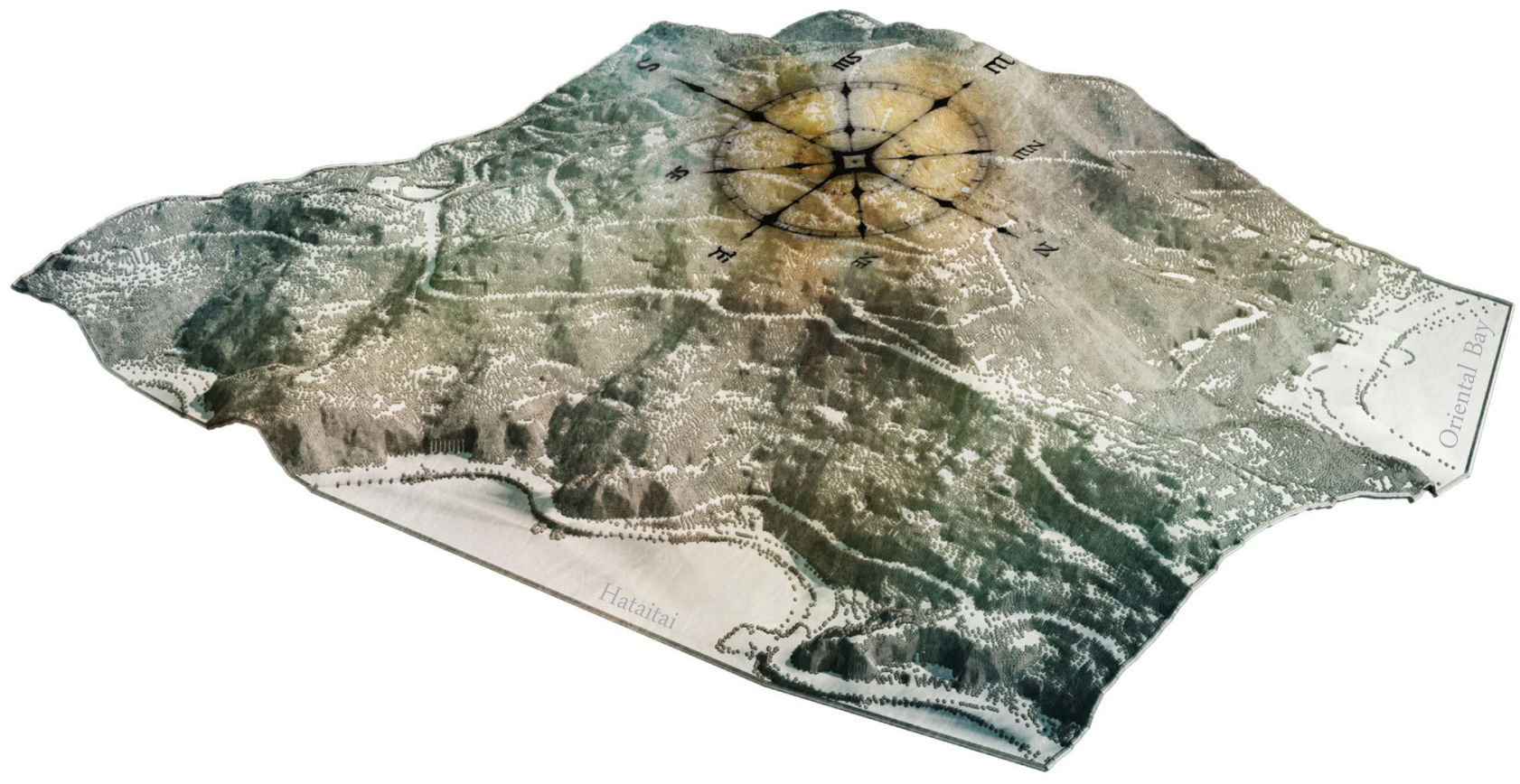

a)

Figure 28 a) 3d map of Mount Victoria topography highlighting the proposed site.

The image shows that the Centennial Lookout is mostly shielded from southerly winds by the Main Lookout point behind it 


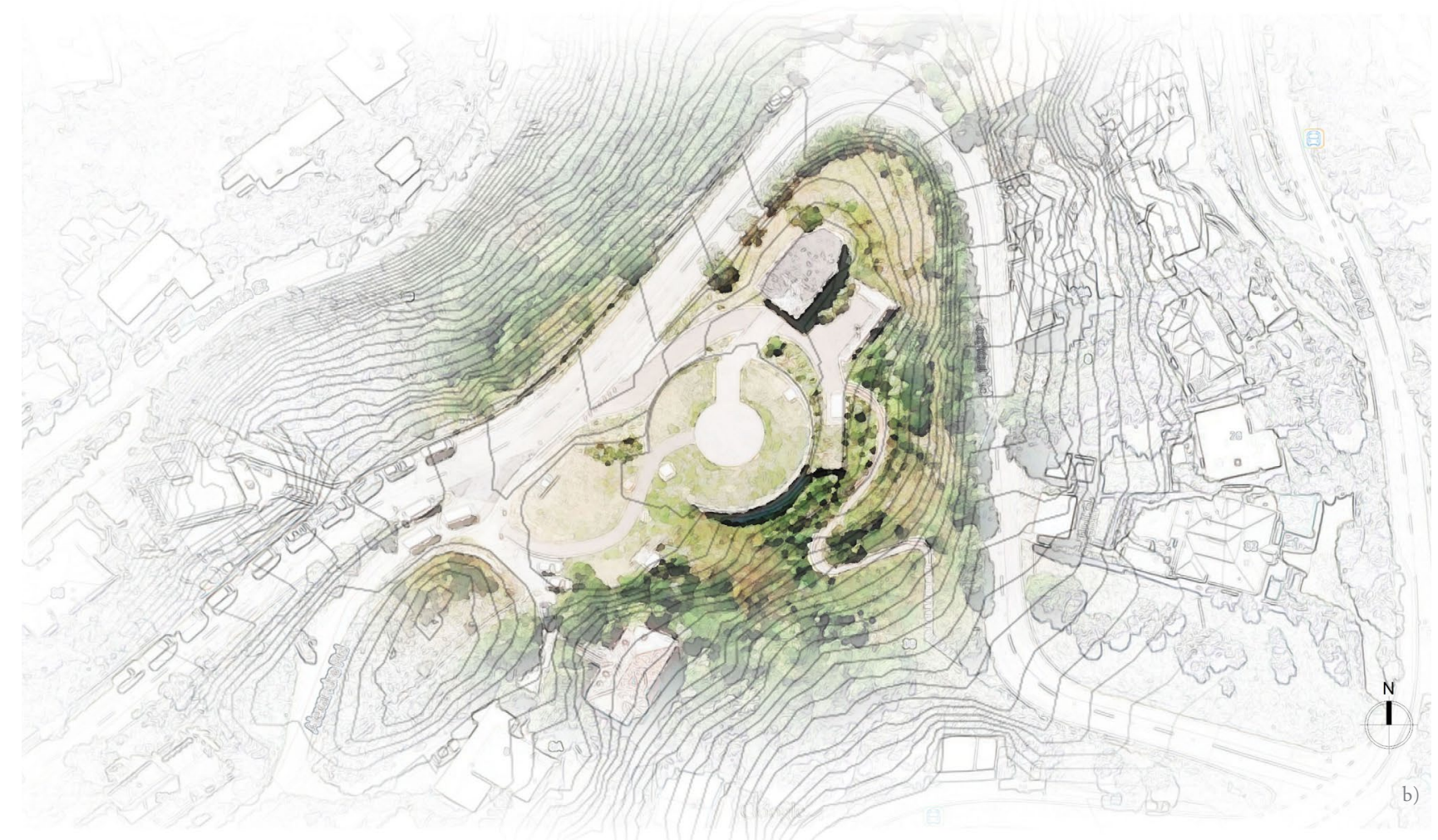

Figure $28 \mathrm{~b}$ ) Closer up view of proposed site overlaid with $1 \mathrm{~m}$ vertical height contour lines 


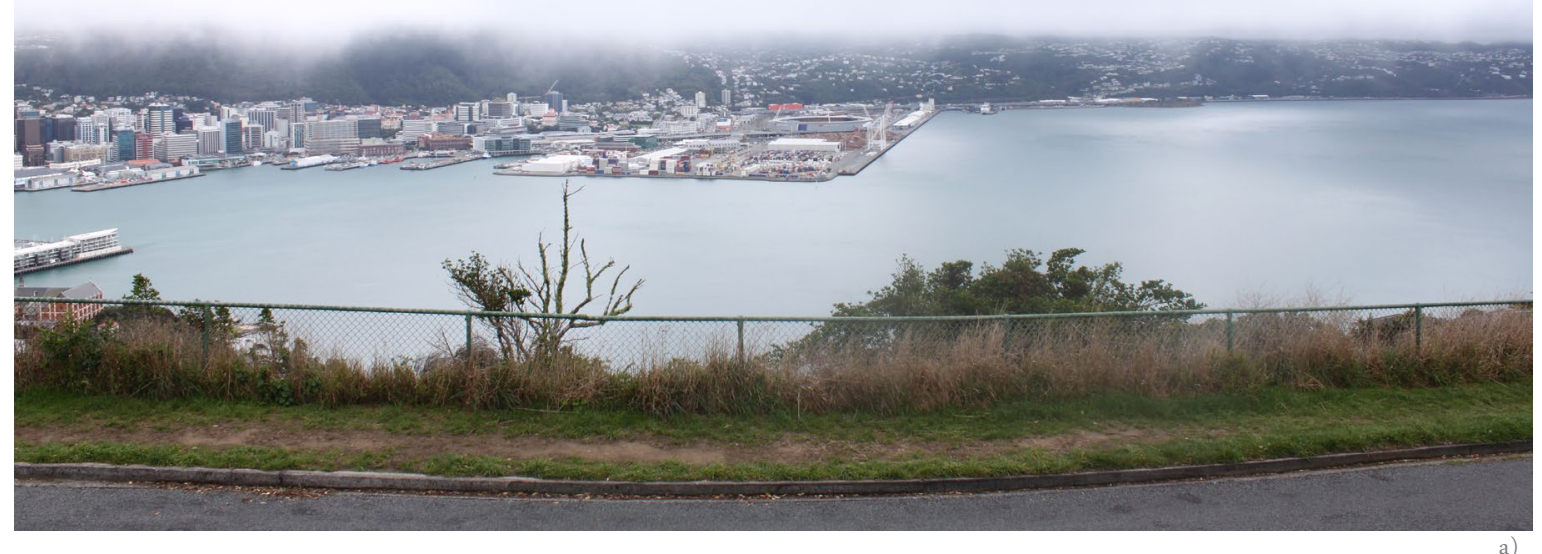

Figure 29 a) Photograph of Wellington city and harbour views

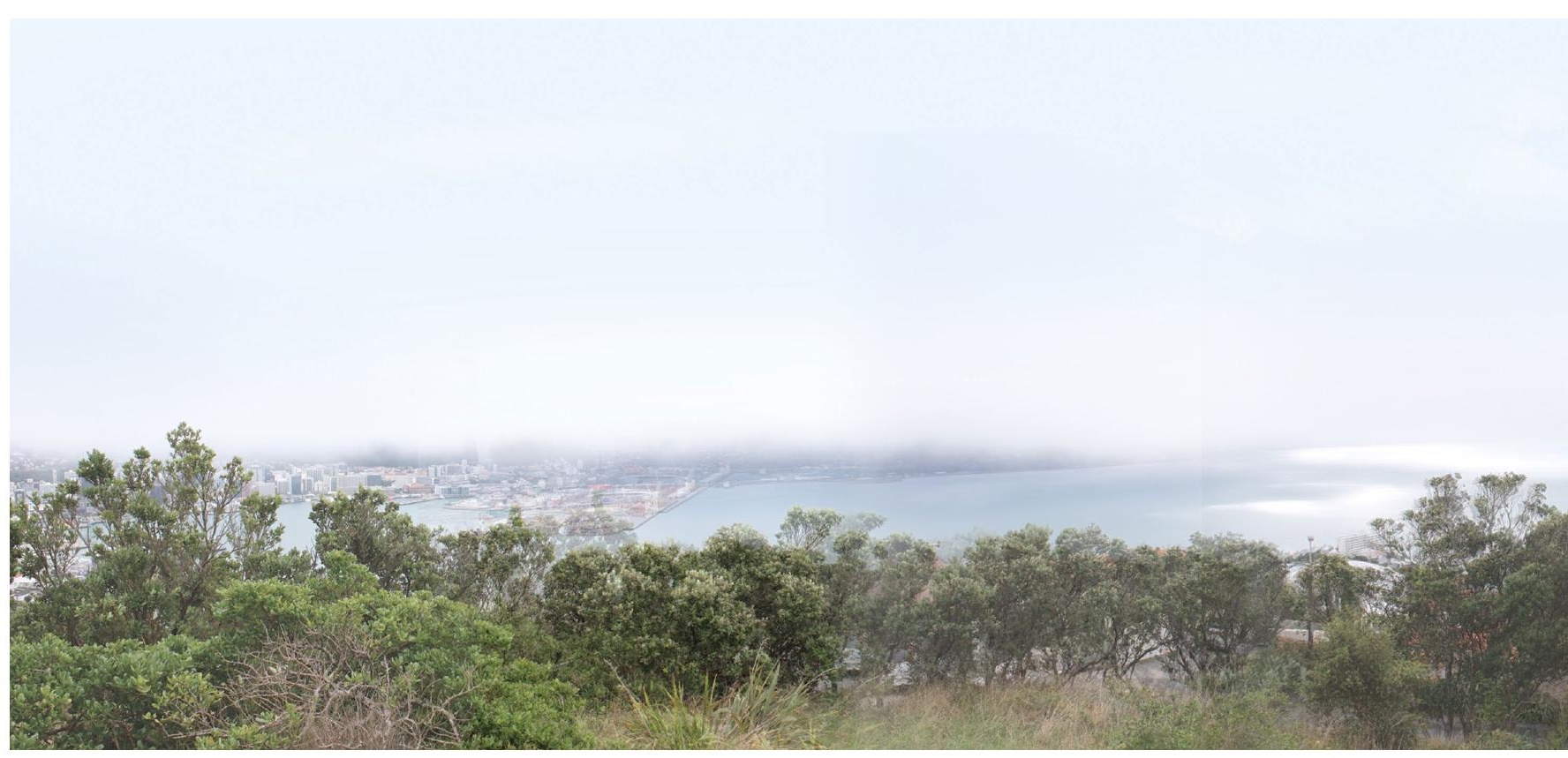

Figure 30) Panoramic composition of the views seen from the proposed site, visually connecting to the surrounding environment 


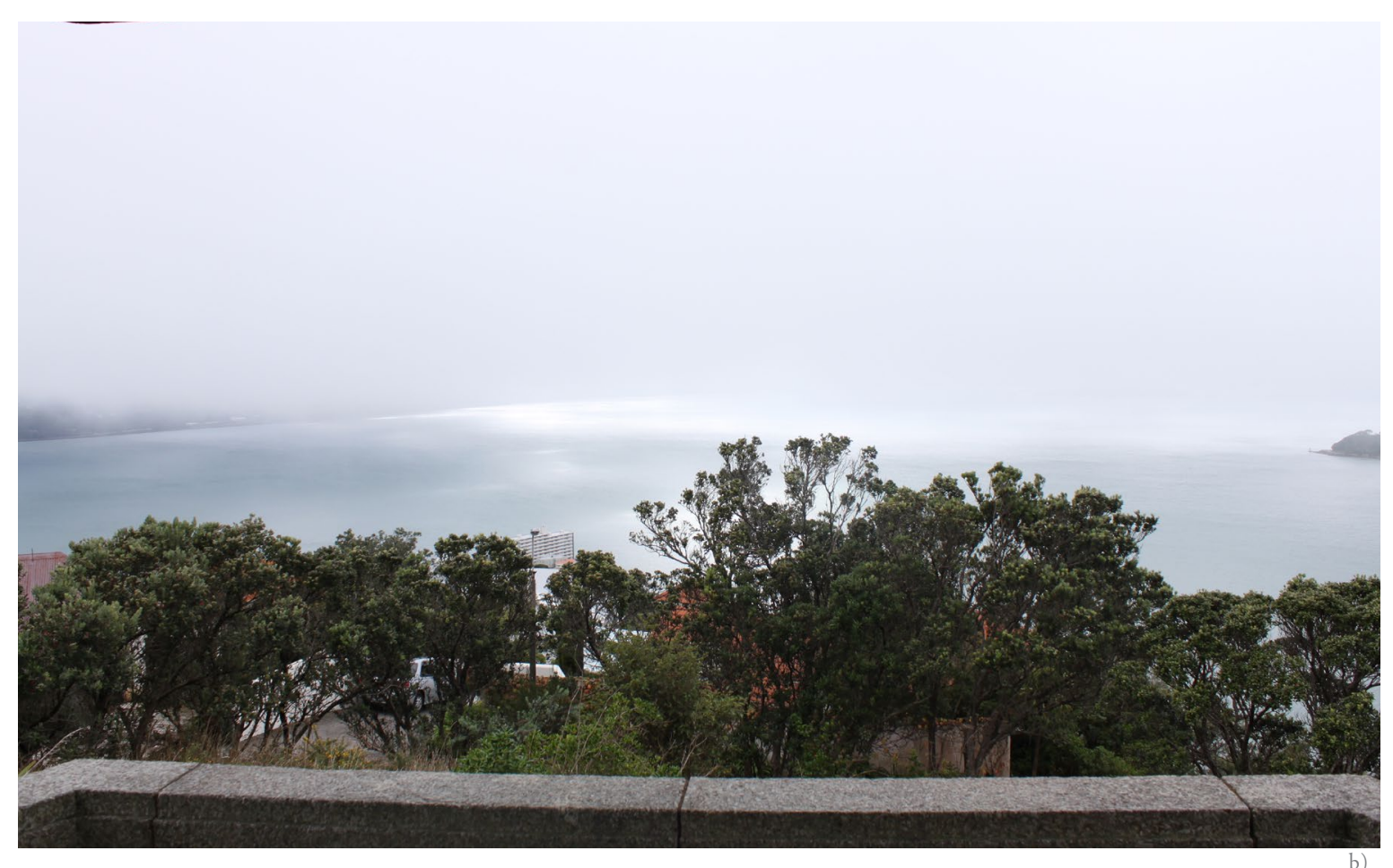

Figure 29 b) View of the Tasman Sea from Centennial Lookout point

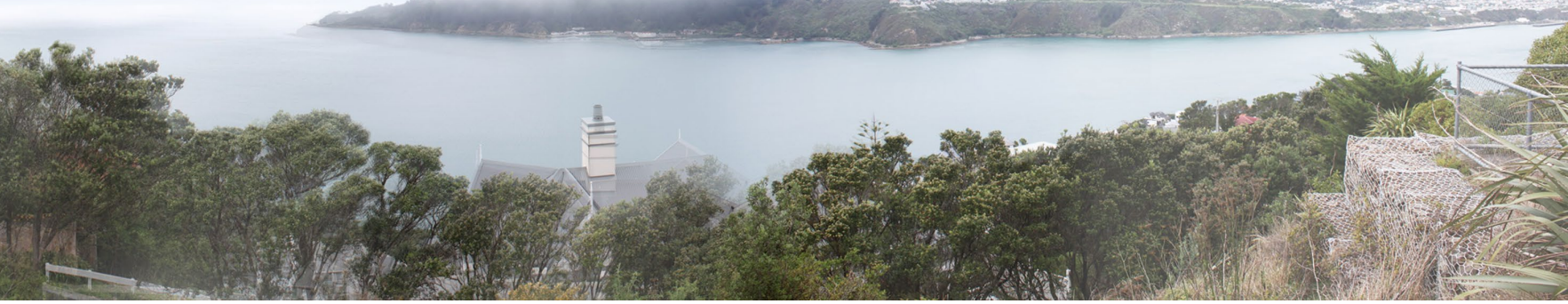


4.5 Historical Analysis

The site is historically significant but often disregarded by visitors as well as residents of the city. The existing pavilion was inaugurated on 15th March 1940, to commemorate the founding fathers of Wellington, and to mark the 100th year of settlement in New Zealand. ${ }^{10}$ The stone construction has a thin and light weight roof curving down to two chunky pillars. One of the two pillars holds two bronze head busts of Arthur Wellesley, the 1st Duke of Wellington and of Edward Gibbon Wakefield, who was involved in the colonisation of New Zealand. The other pillar holds a Bronze Information Plaque explaining the purpose of the Pavilion and the history. The Pavilion also includes a bronze orientation table with detailed information of the precincts in the city and the directions. (Fig. 31)

These historical figures are important to the integrity of the site, however it has been 75 years since the construction of pavilion and therefore needs restoration of aesthetic. The lightness of the concrete roof appears fragile in comparison to the monolithic pillars and the stone wall balustrade around the perimeter. For this design proposition, the structure of the pavilion including the stone wall, will be removed. Retaining the orientation table and the two busts will be noble as it will express a sense of respect for the symbolic architecture and the history. The new intervention will aim to mimic the lightness of the Pavilion's concrete structure in a contemporary manner.

Lookout."

${ }^{11}$ Barrie, T. The Sacred ... $42-46$

12 "Ngake and Whataitai the Taniwha of Wellington Harbour.”

4.5.1 Wellington Harbour and Mount Victoria

- Maori legend

Narrative design methods are effective in establishing meaning and hierarchy in the overall design. As analysed in the theoretical framework, relatable, the space should reflect on the special stories or legends of the site. ${ }^{11}$ This will allow the design to respond specifically to the site. The intention of this proposition is to invoke spiritual atmosphere around those who will visit the Sanctum. Maori legends often have spiritual significance and these influence their current beliefs. Taking a well known Maori legend and using it as an underlying narrative in the design will reinforce the New Zealand perspective for the proposition.

Wellington Harbour is renowned for the Maori legend of Ngake and Whataitai. Their story can be adapted as an underlying narrative and referenced through subtle notions in the design. The tale is one of journey and transformation which fits well within the theme of my thesis. ${ }^{12}$ (App. 3)

The legend of the Taniwha has many key concepts of spiritual journey referenced in it. The innate search for freedom and happiness exists within everyone. Ngake and Whataitai both found happiness but through different ways which translates to how all of us have different paths that we follow. The notion of transformation and journey in this tale will be considered in the design of the Sanctum.

\subsection{Conclusion}

As analysed in this chapter, the site and all its relative components are important to the process of this thesis. The design will incorporate the key findings of this analysis and consequently ensure that the design in site-specific. for sacred architecture to be meaningful and
Selecting the site for this thesis is one of the most fundamental tasks. The criteria derives from theoretical research of sacred sites, and the intentions of bringing the sacred to the city. 
The Centennial Look-out provides landscape which best responds to the criteria as it is within close proximity of the city, easily accessible, and has cultural and historical value, as well as communicating a sense of pilgrimage up the hill. The journey of the pilgrimage, referring to Coelho's story, changed his perspective of the world and elevated his spiritual consciousness. Since we all have different perceptions and paths that we choose, it will be difficult to create an intervention which forces one to experience one particular path in a specific or certain way. The design will need to incorporate the idea of pilgrimage in a simple manner and therefore be open for people to move through the spaces freely, and in their own way.

In the interior design discipline, the site is often within an existing structure. This means that analysis climate and site is not useful. However, the proposed site of the Centennial Look-out is an exposed location so an understanding of climate and land conditions is necessary. The design will manipulating sound and light qualities by taking advantage of the wind channelling in from the north west direction, and the sun path from east to west. In this way, these notions will enhance the sacred atmosphere connection to the natural elements.

Topography analysis shows that the site naturally aligns to the north east direction and the existing land has a central circular form which tapers out towards the harbour view. The design will embody the ideas of a central axis and the four cardinal directions within the different spaces, thus referencing a universally employed spatial planning device found in sacred architecture. The Sanctum is for New Zealand therefore it is important to respect the heritage of the site and the ancestry legends it beholds. The light concrete centennial memorial for Wellington and the story of the Taniwha will be important to express through the design, as it will reinforce the New Zealand context.

The site proves to be a crucial aspect of the design process. The findings of the in-depth analysis will help to produce a design solution which is meaningful to the context of the site, and influential to the given intention of my design for the Sanctum. 

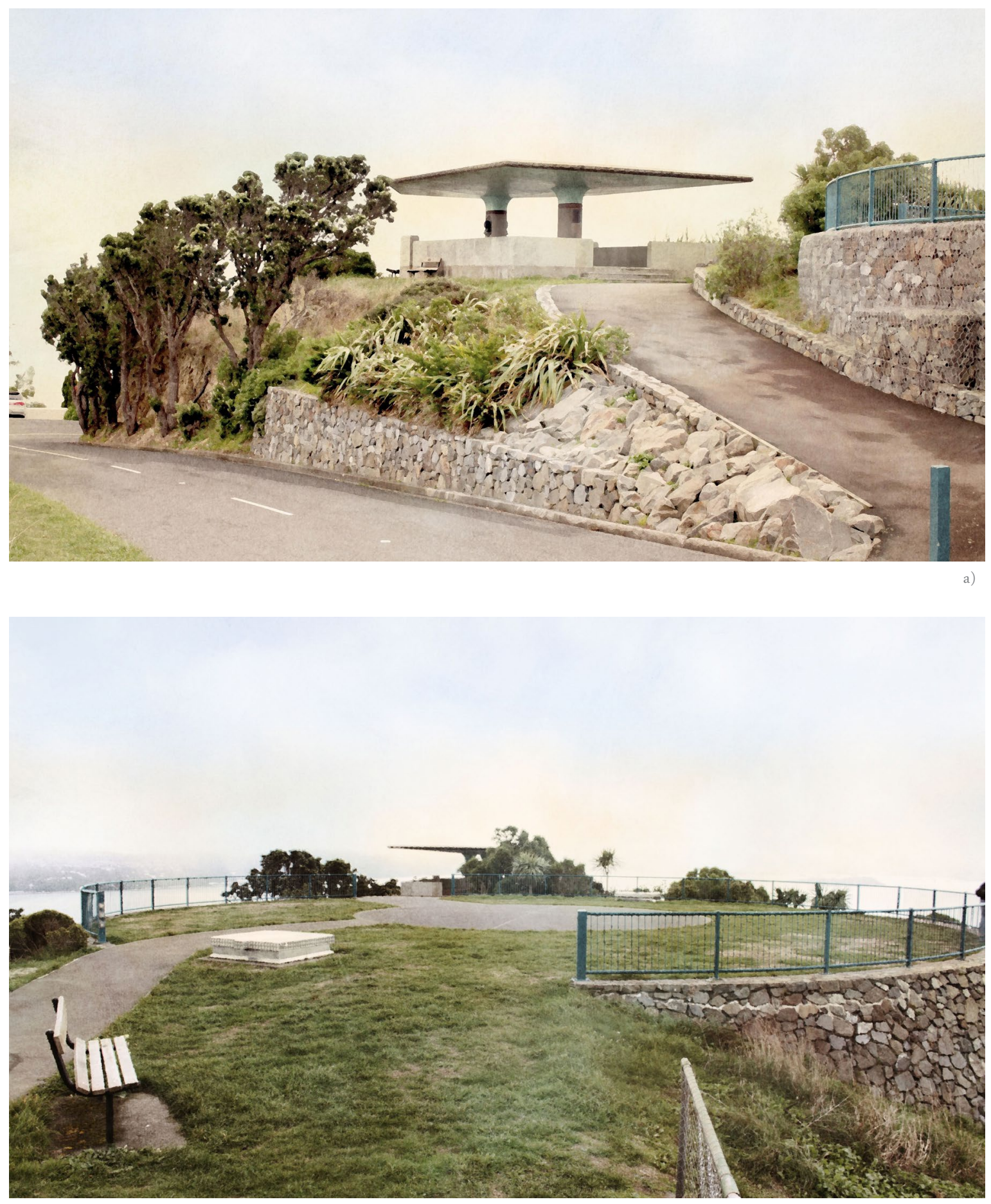

b)

Figure 31) Existing site photographs: a) view from Lookout road, b) view of overall site ... 


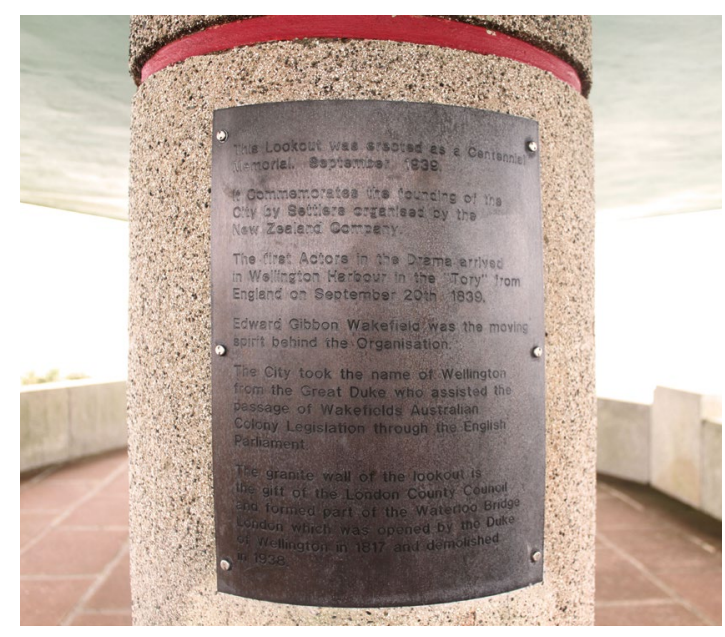

c)

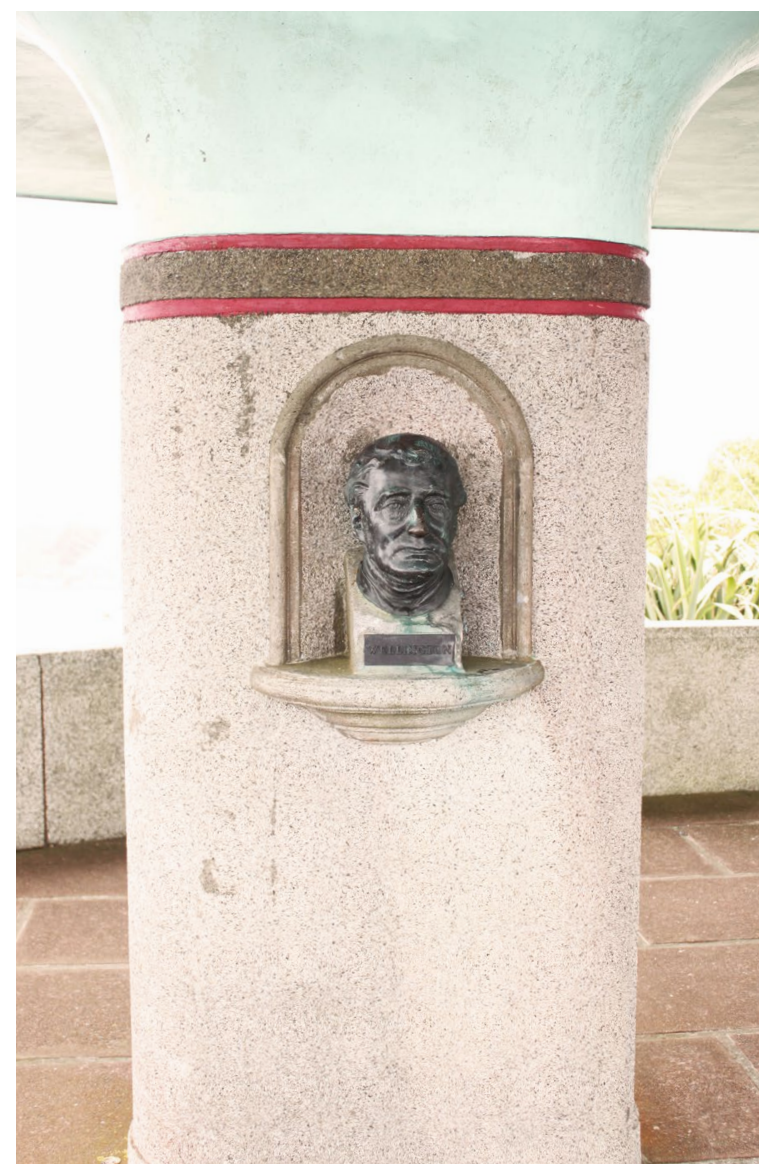

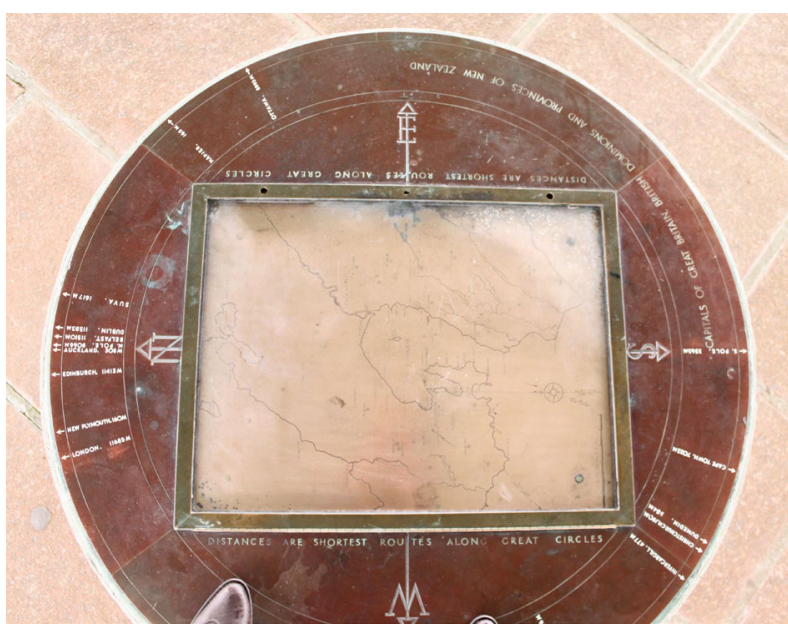

d)
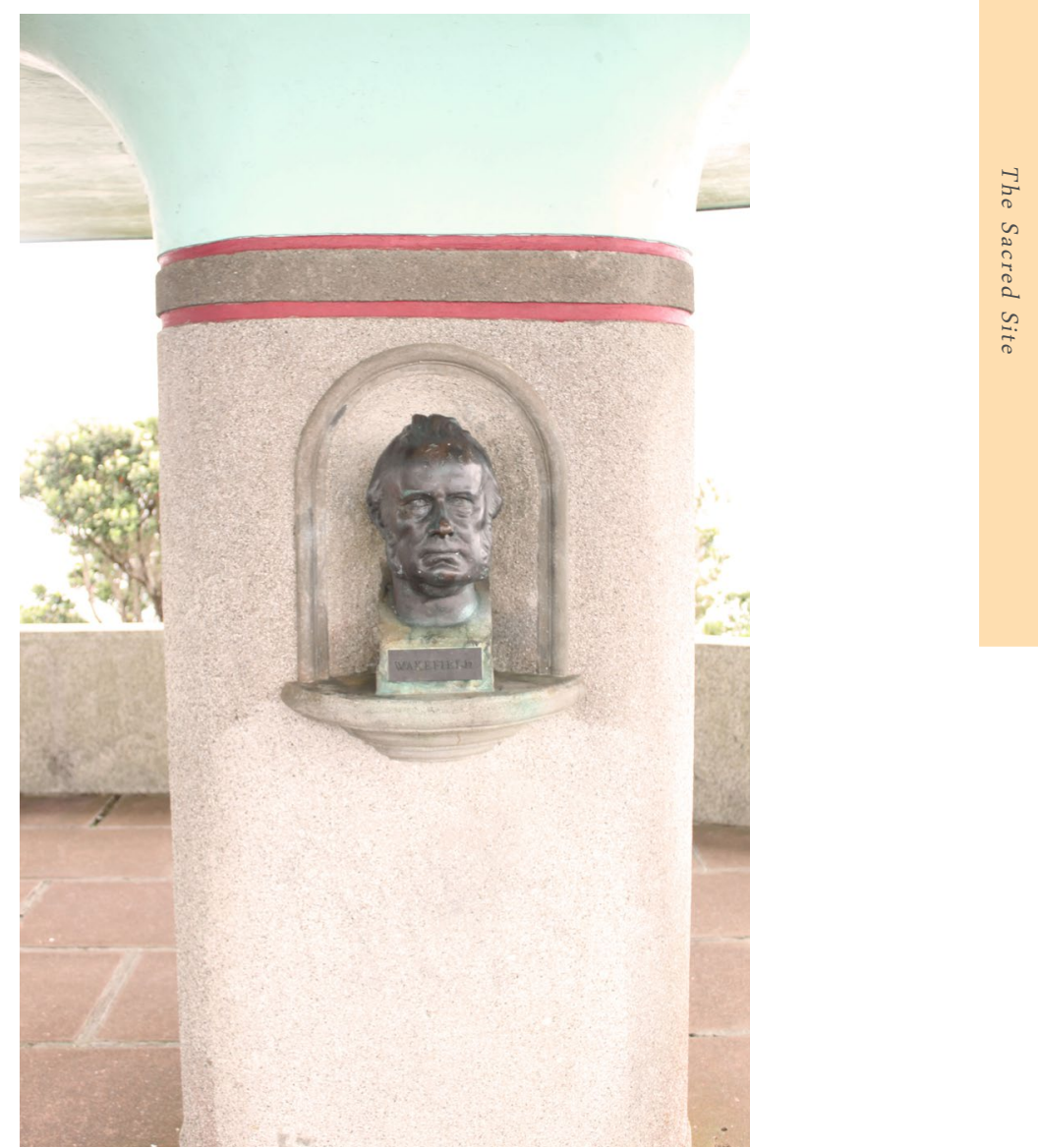

e)

Figure 31) c) Information Plaque, d) Orientation Table, and e) Bust heads on columns: Arthur Wellesley (left) and Edward G. Wakefield (right) 
CHAPTER FIVE 


\section{SACRED SPATIAL MANIFESTATIONS}

\subsection{Introduction}

This section follows a series of case studies which examine contemporary and modern examples of sacred architecture according to the methodologies reflected upon in the Literature Review. The following analysis will look at specific qualities in the case studies which make them a successful space for spiritual reflection and how the particular architectural notions achieve this atmosphere.

\subsection{Tadao Ando - WATER TEMPLE,}

Hompuku-ji, Awaji Island, Japan, 1991

Tadao Ando is renowned for his manipulation of light on pure concrete. $\mathrm{He}$ is known for minimal architectural elements which articulate powerful atmospheres. Many of his works are aesthetically of sacred nature. They often suggest transcendental qualities beyond programmatic requirements of the space. The Water Temple on Awaji Island dedicated to Tantric Buddhism, is a seminal project which expresses the essence of contemporary sacred architecture. The temple conveys distinct symbolism and geometry through its form, and the simple articulation of light and materials evoke a placid atmosphere.

The Water Temple guides visitors to the heart of the shrine through the architecture. Before entering the interior, visitors ascend to the top of the hill where a long concrete corridor, three metres high, draws people to the expansive water pond in the form of an ellipse. (Fig. 32) The lotus flowers float on the water pond which is bisected in the centre with a narrow concrete stairwell leading to the underground prayer hall. (Fig. 33) In the space bellow, light seeps through from behind a Buddha statue and onto the vermilion red timber lattice structure, creating a warm and meditative ambience. ${ }^{1}$

The spaces are divided through simple yet symbolic shapes of the circle, ellipse and the square which create a clean hierarchy in the way one moves through the temple. (Fig. 34) The concrete curved wall, leading to the ellipse pond, is effective in moving people into the temple because it is a narrow and tall passageway which opens out like an aperture, inducing anticipation of the sacred space. (Fig. 35)

The way in which spaces are organised vertically above and below ground is quite interesting. The serene water pond being the first element visitors see, immediately takes them to a sacred consciousness where the water is perceived as a sign of peace and asceticism. Then, the descent into the various spaces below ground, bring people to a sense of concentration and oneness with the earth. (Fig. 36) This spatial planning device is useful to understand and be influenced by when drawing out spaces for the design experiments. Exploring the existing forms of the site in Mount Victoria, and manipulating the archetypal symbol of the circle, rectangle and square, are possible ways to incorporate this method into my design process.

Ando is well known for creating eerie effects with light. The Water Temple is no different from his other works, in that the light is incredibly articulated in the interior of the underground spaces. The elliptical structure is partly above ground which allows glimmers of light into the space. ${ }^{2}$ The intensity of the light is enhanced by the use of vermilion red on the timber columns and latticed screens which divide the interior spaces into squares within the circular form. Bringing natural light at a high angle from the southern direction, allows the interior to have a 
magical and spiritual feel. (Fig. 38) This technique can be deployed in the design experiments by playing with height of structure and placement of openings and apertures in order to maximise the natural lighting on site.

The Water temple has a strong contrast from the underground to above ground in terms of atmosphere. This is achieved through colour and materiality of the strong red timber in the interior to the green and grey concrete cool tones used outside. ${ }^{3}$ This contrast reinforces the idea of the space being for spiritual escapes rather than for regular everyday activities. The choice of materiality and how it is articulated can help to create a similar contrast within my own design.

Tadao Ando's Water Temple is an excellent precedent study for the intention of this designled thesis, as it illustrates the essence of spiritual architecture in a contemporary context without explicitly referencing specific religious symbols or ritualistic architectural elements. Ando has many other projects which work in a similar manner to the Water Temple by the way of spatial geometric planning and unique manipulation of light. However, this temple in particular is specifically useful to this thesis as it engages in the idea of pilgrimage and journey which is key to my research, and the existing site of the temple is also of similar characteristic to the site of Mount Victoria. 


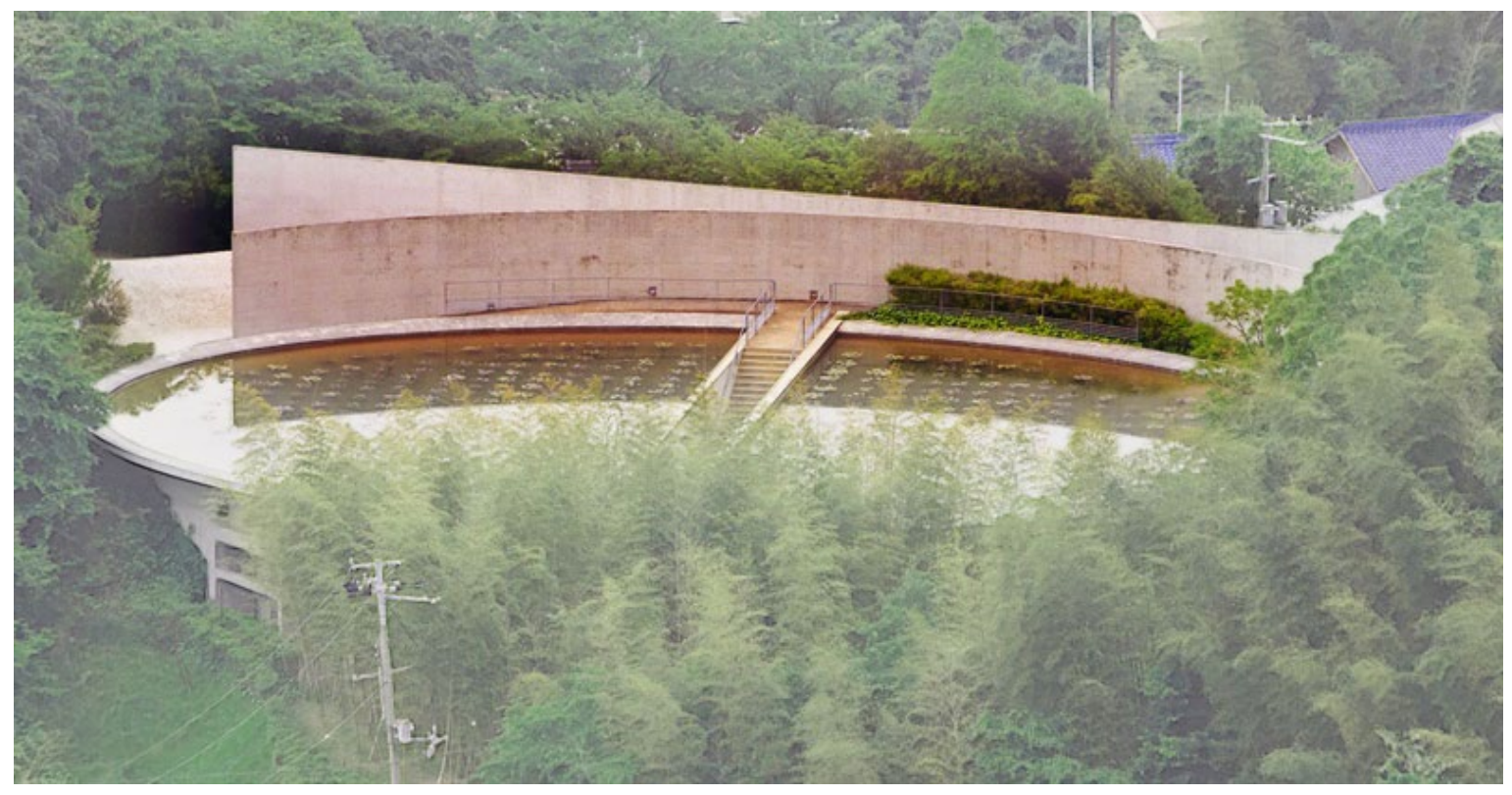

Figure 32) Highlighting the long corridor passageway leading to the Water Temple

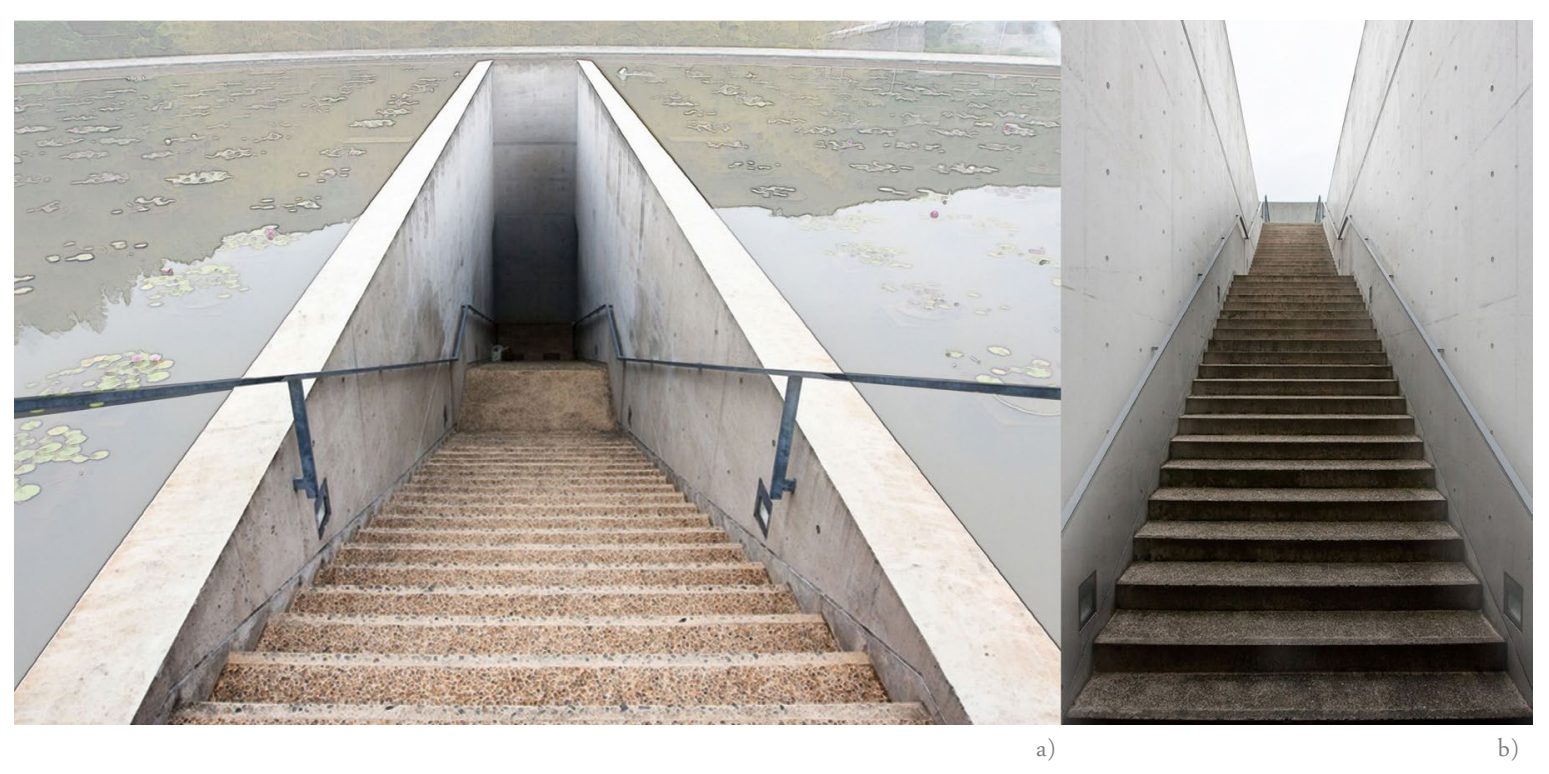

Figure 33) Highlighting stairwell to the underground spaces: view looking down (a) and view looking up (b) 


$$
12
$$




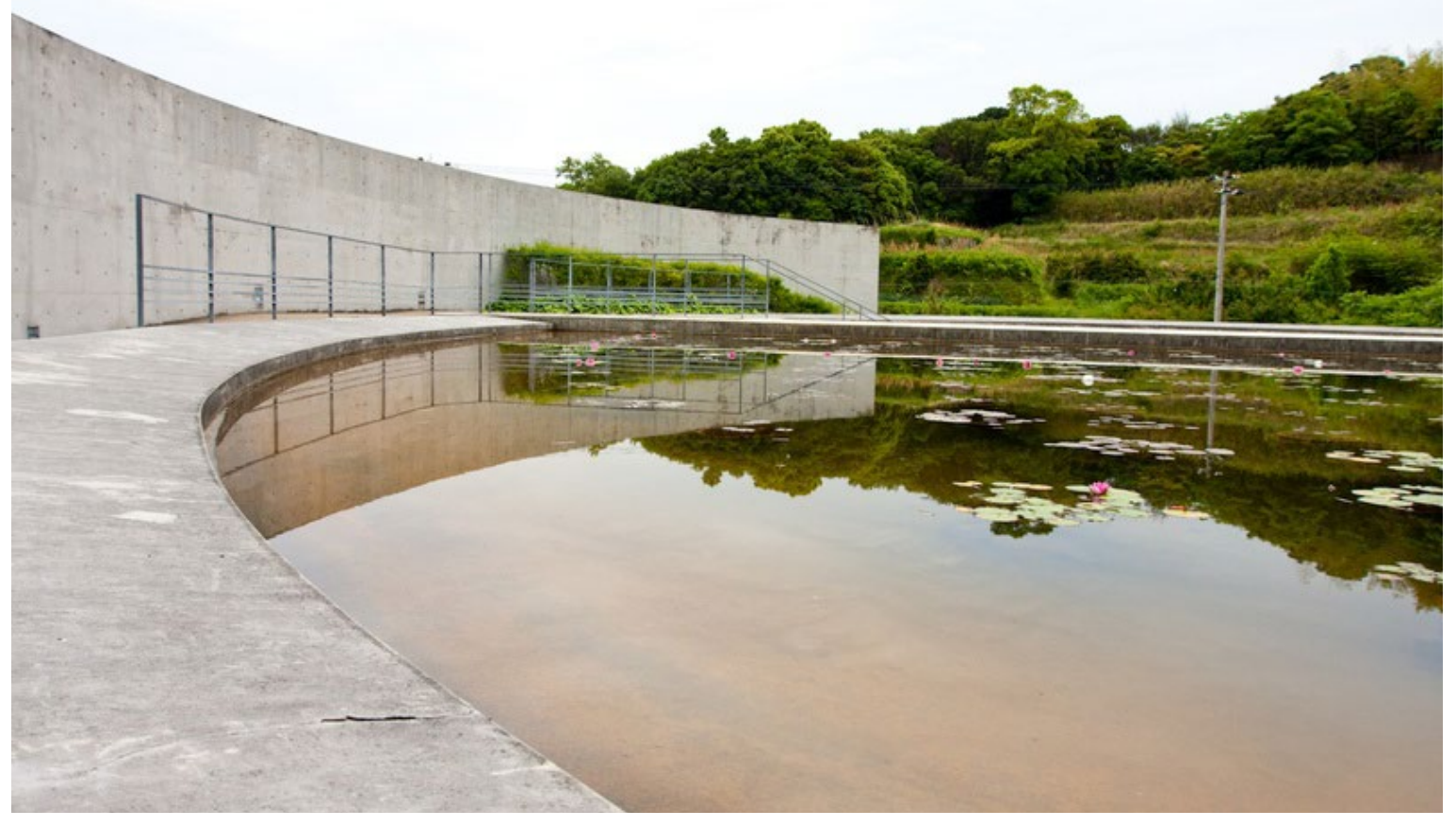

Figure 36) Stairwell to spaces below the water pond - visitors are taken to a sacred consciousness

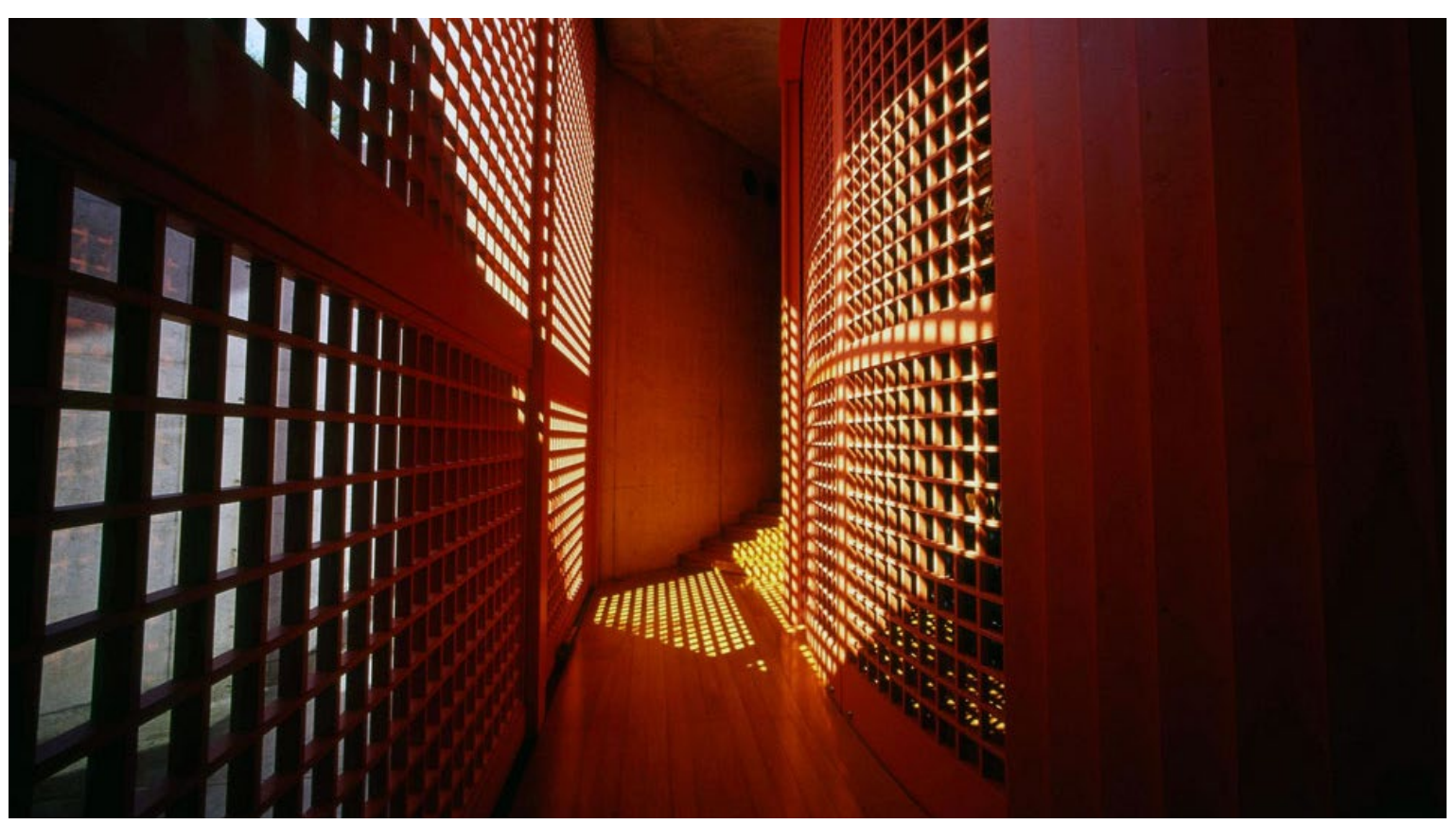

Figure 37) Light through the Vermilion Red Lattice screens expressing warm and intense spiritual atmosphere 


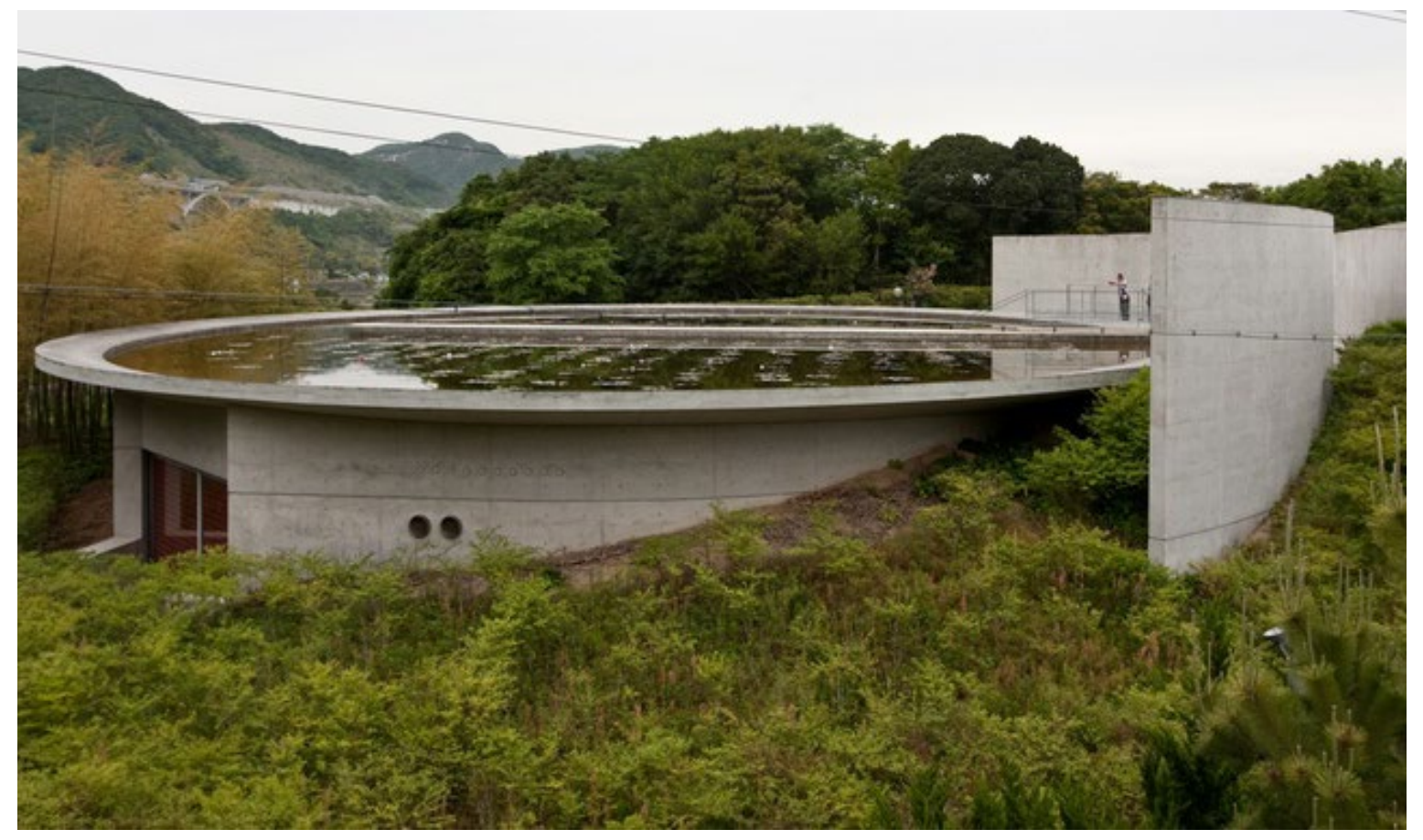

Figure 38) Overall view of the Water Temple

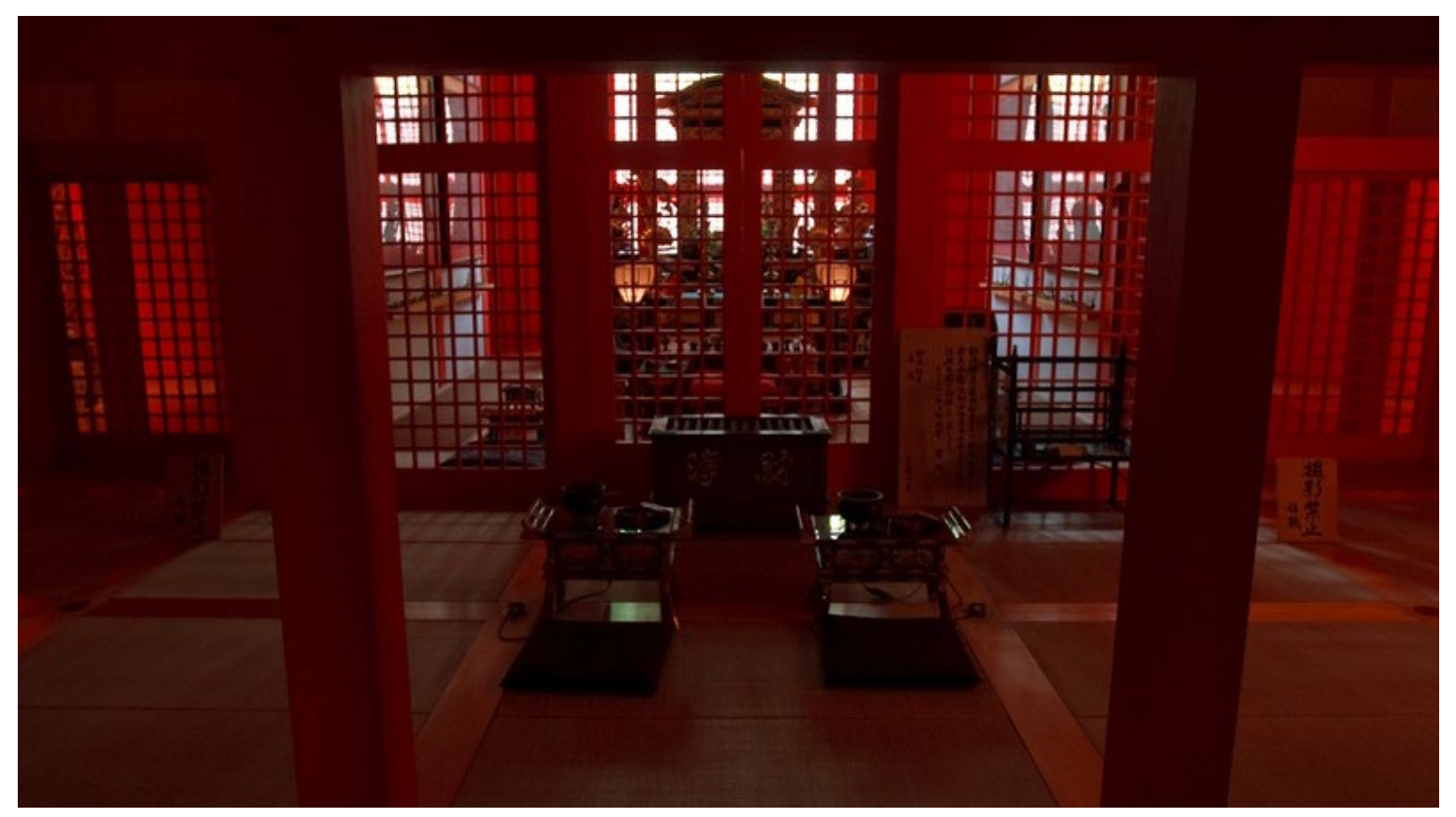

Figure 39) Main Prayer Hall in the underground space - spatially different atmosphere/aesthetic to the outside, however both express sacred qualities. 
5.2 Moshe Safdie - YAD VASHEM

HOLOCAUST MUSEUM, HaZikaron,

\section{Jerusalem, Israel, 2005}

Israeli-Canadian Architect Moshe Safdie is well recognised for his monumental structures which are organic in form and have particular placement of openings and green spaces. Safdie apprenticed with distinguished architect Louis Kahn in Philadelphia and was influenced by his approaches to architecture. Safdie's work comes from the desire to create meaningful spaces which improve communities and add value to the environment. ${ }^{4}$ Safdie describes 'Architecture' as opposed to 'buildings' saying that it

"compromises of the sacred places of worship, culture and government through which we aim for the sublime ... The Spiritual embraces the realms of iconography and symbol, ornamentation and celebration." 5

One of Sadie's notable works is the Yad Vashem Holocaust Museum in Jerusalem. The structure is predominantly concrete with glass yet merges into the natural and hilly surroundings. The Museum stretches across the hill, perpendicular to the peak in a triangular prism form, creating a sense of journey through the length of the building. (Fig. 40) Spatial qualities in the Museum which attain sacred atmosphere are the expression of natural light and the articulation of proportion and materiality with form. Although the Museum is not specifically religious, the interior spaces are dedicated to spiritual acts of remembrance and reflection, not only for the Jewish community, but for everyone.

${ }^{6}$ Safdie, M. 205 thin ceiling trellises referencing traditional Israeli or Middle Eastern architecture. This delicate light filtration contrast with the monolithic and rectangular concrete forms. The light and shadows in this space change throughout the day which creates an interesting dynamic space. The tone of the space is kept neutral so the attention of visitors are drawn to the light. (Fig. 41) The continuous skylight which runs across the triangular prism structure, produces a similar mystical atmosphere to the reception space. The triangular glass washes the various gallery spaces with light from above. ${ }^{6}$ (Fig. 42 and 43) In both instances, the light is revealed in a way which enhances the sacred experience of the interior spaces.

Manipulation of light through the architecture is one of the key techniques which can help to create a sacred space as seen analogously in Ando's work. My design experiments will intend to follow these techniques by similarly taking advantage of natural light during the day, and constructing the architecture to filter this light in unique ways.

The forms articulated in the Holocaust Museum are particularly interesting as they experiment with scale and proportion. (Fig. 44) The triangular prism which acts as the body of the building, tapers upwards drawing the attention to the sky. This enhances the idea of verticality and proportion which is used commonly in sacred architecture. The vertical structure invokes grandeur of the spiritual and directs the viewers to the heavens above. The particular lighting used in this space further emphasises the tapering form. The consistent use of concrete throughout the building creates a holistic and cohesive design language and expresses sacred quality in the 
interior by drawing focus to the intention of the space. At the end of the journey through the Museum, the prism opens out to the views of the mountain range and Jerusalem city below. (Fig. 45) This architectural gesture allows visitors to become one with the surrounding nature. ${ }^{7}$

Symbolism, through form and scale in this precedent, is evident architecturally rather than decoratively or ritualistically, which enables visitors from any religious or cultural background to experience the sacredness of the interior. Experimenting with scale and proportion of forms in a similar way to the Holocaust Museum, will be imperative to the design process as it will help to achieve a universally spiritual atmosphere without referencing specific religions.

Safdie's Holocaust Museum presents a contemporary form of sacred architecture through specific spatial conditions. The distinct light filtration techniques and the manipulation of the triangular form and concrete material provides examples of ways to achieve sacred feeling of space without the need of specific religious symbols. In addition to these spatial qualities, the idea of pilgrimage and journey is subtly conveyed by the long prism structure and the experience this form creates through the array of galleries and other internal spaces. The design of the Museum is a successful example which takes the typology which often seen as secular and transformed it into a space for spiritual reflection for the Jewish community as well as visitors who come from different cultural backgrounds. 


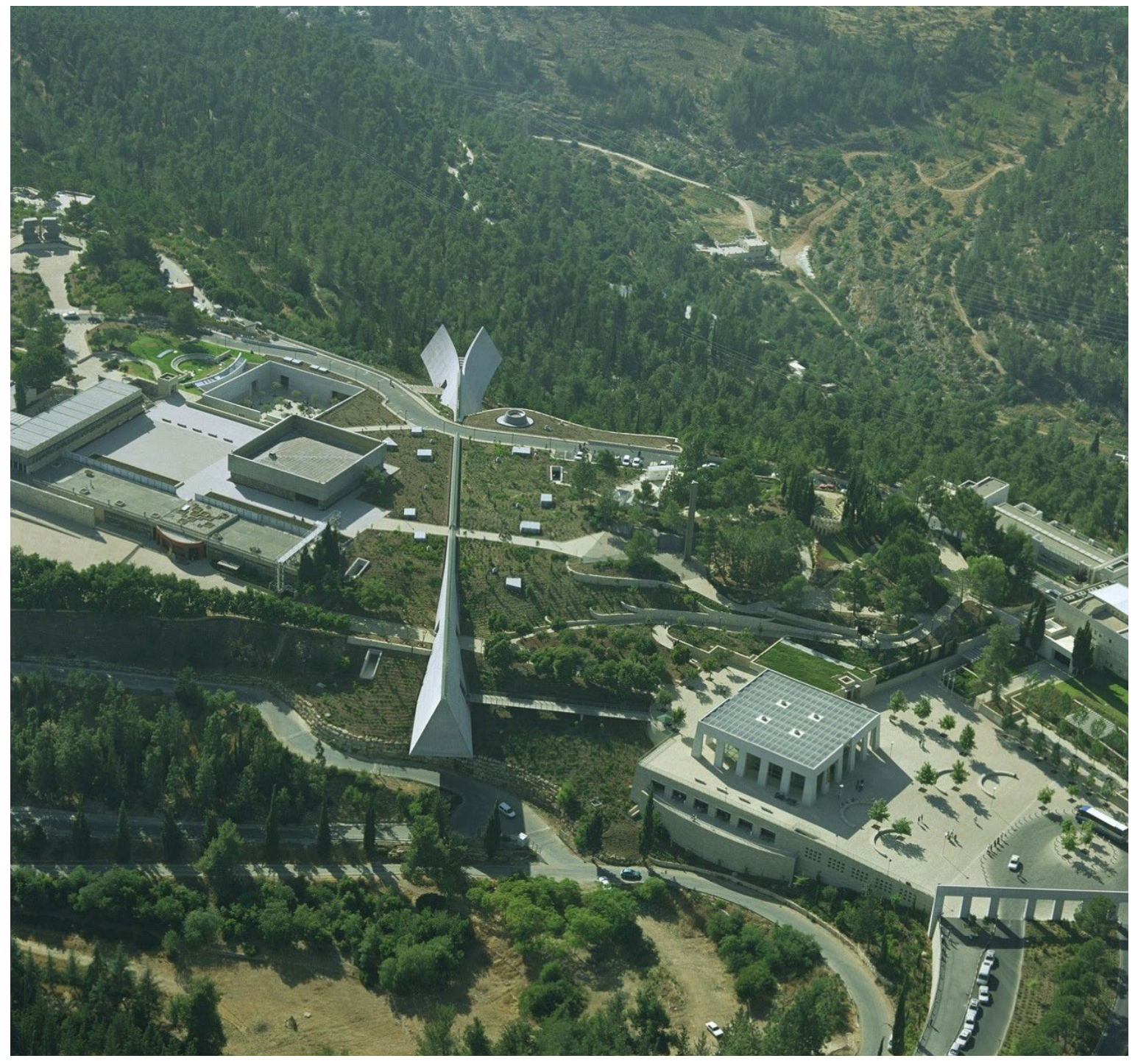

Figure 40) Overview of Yad Vashem in its hilly surrounding context 


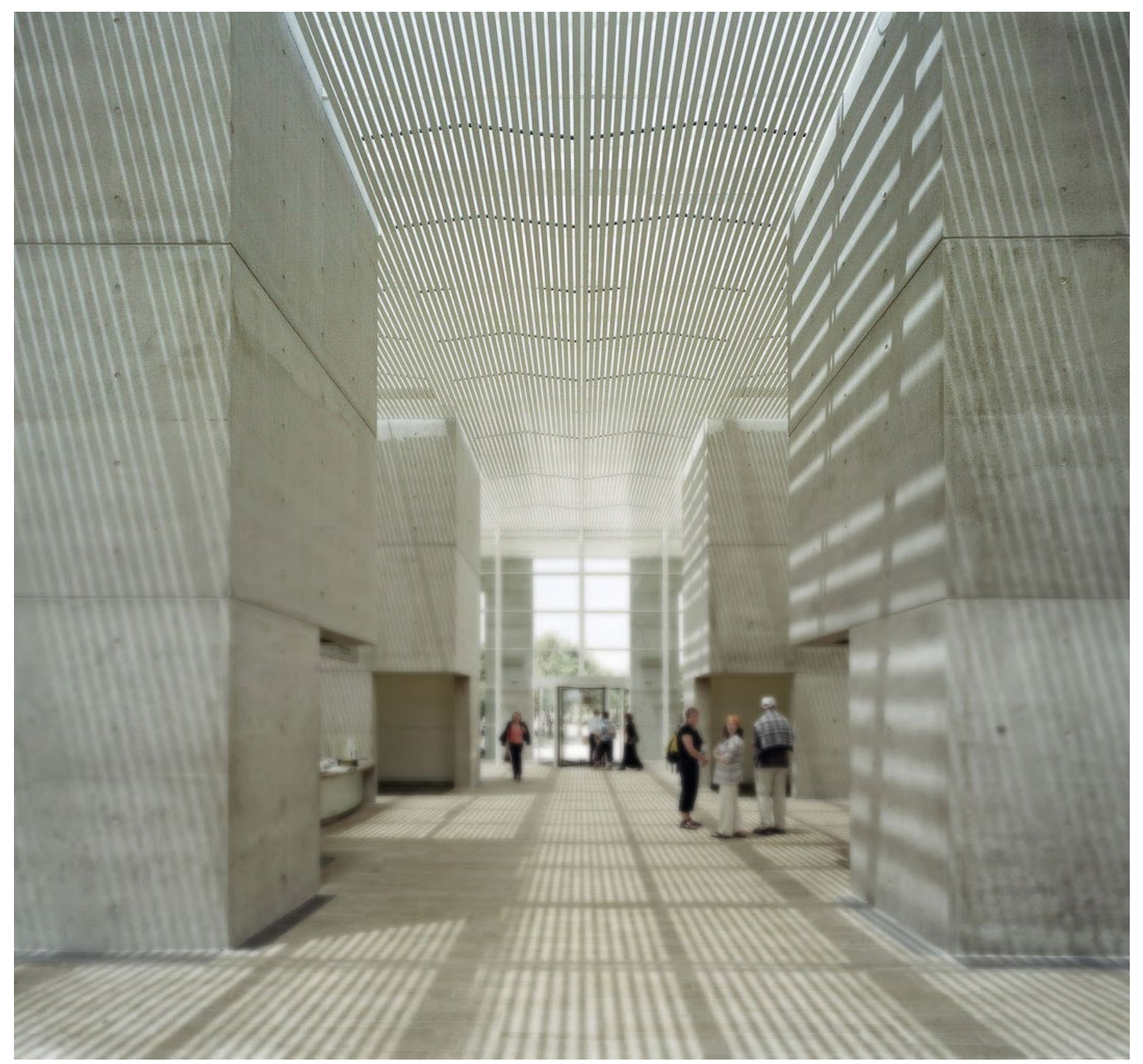

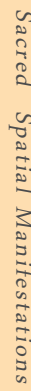

Figure 41) Light filtration through thin screens in contrast with the big concrete structures 


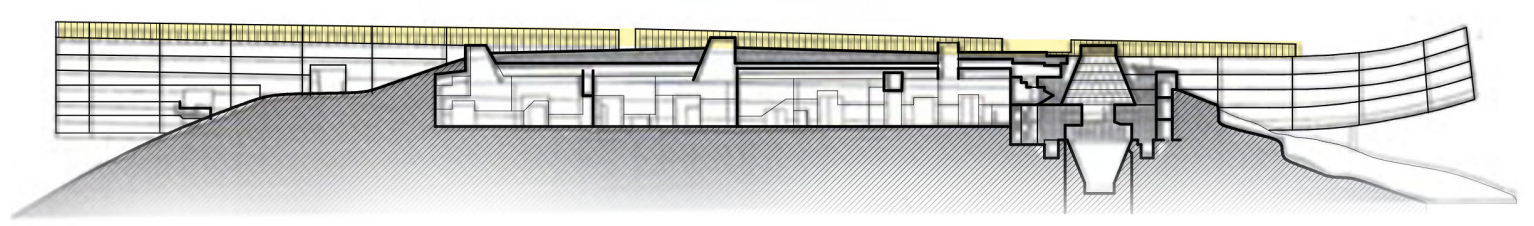

Continuous Skylight

Figure 42) Section drawing showing the skylight which runs through the building drawing light into the interior

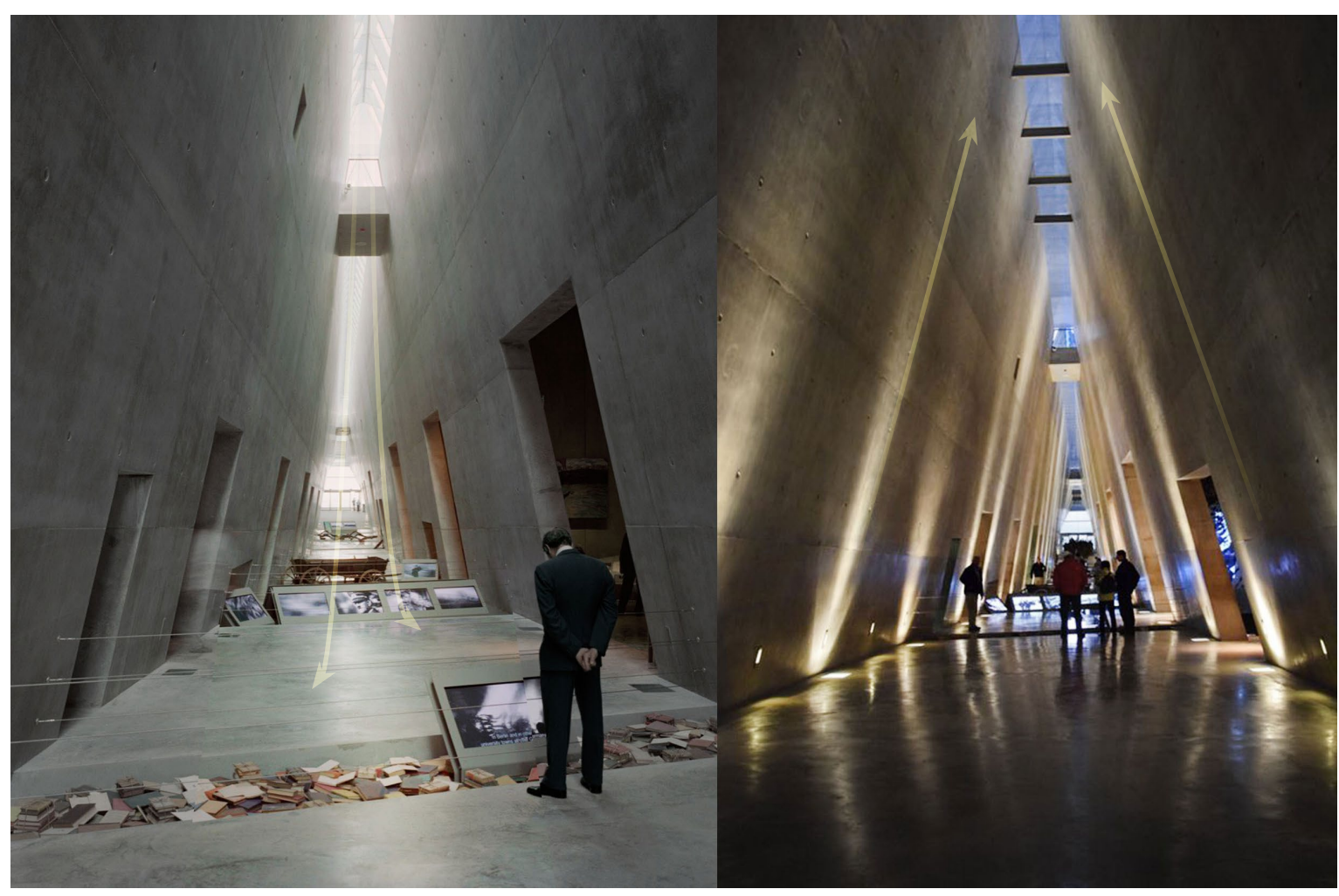

Direction of light

a)

b)

Figure 43) Directional light in the interior: Natural light from above during the day (a) and artificial light beaming upwards at night (b) 


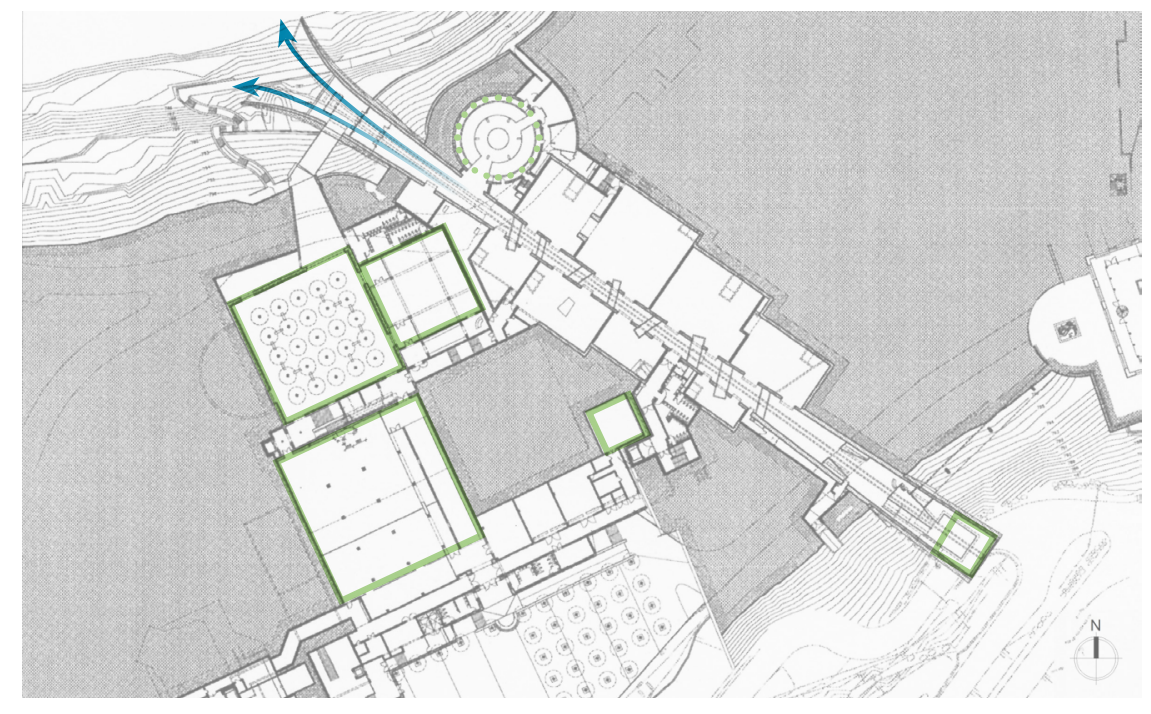

Opening for mountain view

Circular Forms

- Square Forms

Figure 44) Plan drawing analysing formal shapes and symbolic composition

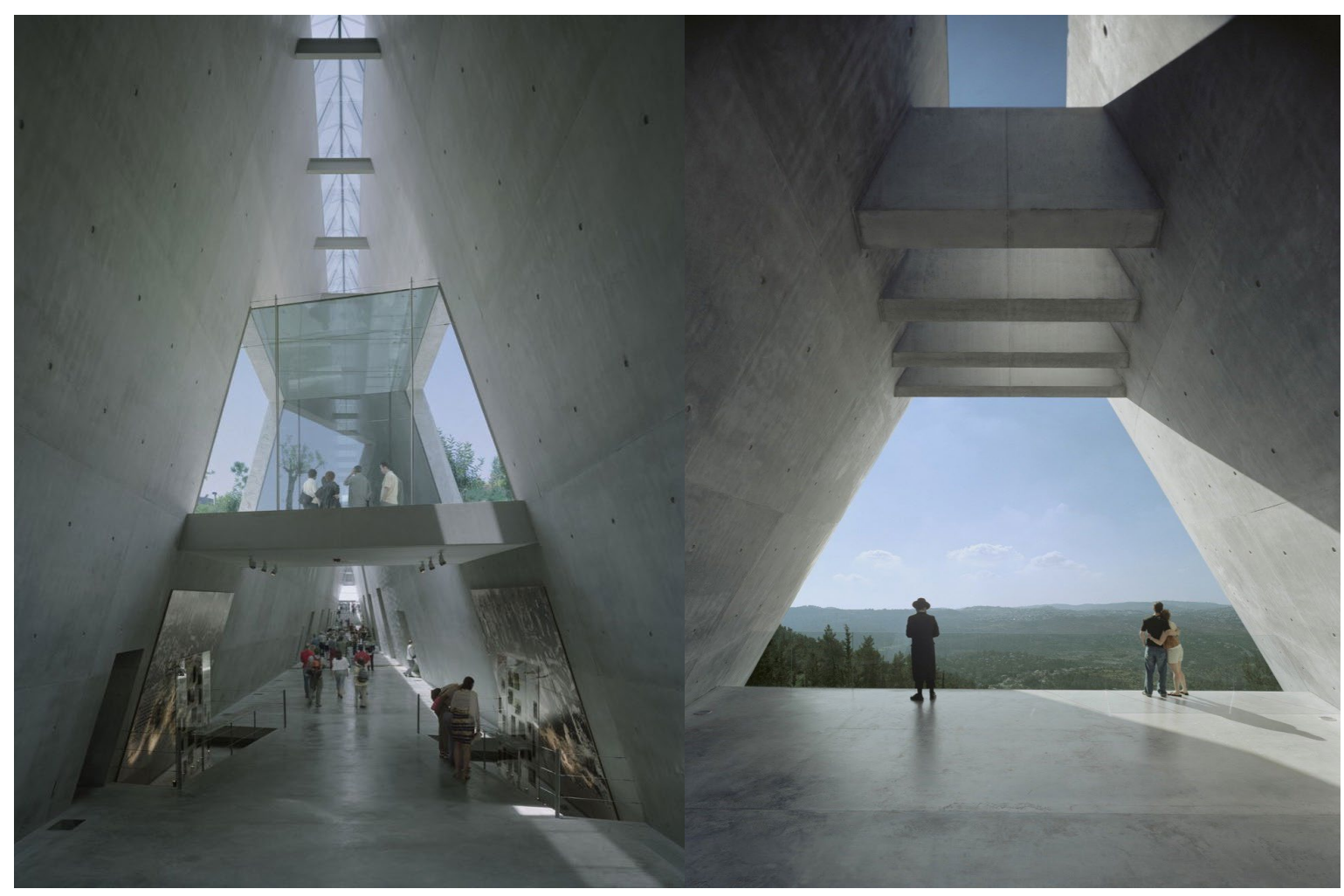

a)

Figure 45) Continuous prism structure of the Jewish Museum from the gallery spaces (a) to the views of the mountain range and city below (b) 


\subsection{WATER \& ARCHITECTURE -}

\section{Carlo Scarpa's Fondazione Querini}

Stampalia 1963 and Louis Kahn's Salk

Institute 1965

Water, as one of the four classical elements, has long been deemed as sacred in religions and in philosophy both western and eastern. It cleanses and purifies one externally and spiritually. ${ }^{8}$ Water can have an interesting relationship with architecture as well. Sustainably, architecture or structure can direct rain water to a filtering tank so that it can be recycled. This can be seen as a gesture of common sense or metaphorically and poetically, as a way of giving new life.

Architecture can also beautify water in a decorative and symbolic way through landscape water features and fountain interventions. When observing water or touching it, the experience instantly feels spiritual, transcending the physical act. This can create a sense of inner-peace and serenity. Architects Carlo Scarpa and Louis Kahn, have produced projects which integrate water in compelling ways. Through fine detailing and compositional techniques of shapes and forms, they achieve sacredness and transcendental qualities of water within their buildings and landscape interventions.

Carlo Scarpa was known for his work within heritage buildings and his acute sense of detailing interiors and landscapes with lavish materials in a contemporary modern context. Many architects and historians struggle to analyse his projects as they are difficult to explain holistically. Through observation and research, one of the key descriptions of his style was the created new forms through old techniques of craft. ${ }^{9}$ Scarpa is most famous for his restoration of Fondzione
Querini Stampalia now converted to a cultural institution in Venice Italy. The gardens in particular have precious materials, like marble and standard materials like concrete, composed together in unusual ways. (Fig. 46) These materials are merged into forms which are then repeated at different scales. The element of water is significantly present in the gardens of Querini Stampalia. (Fig. 47)

The articulation of the water features and the stone motifs are heavily inspired from Japanese water gardens. ${ }^{10} \mathrm{His}$ interventions control the flow of water and the constant sound attracts attention to the exquisite details which creates a serene atmosphere and experience. (Fig. 48)

The way in which Scarpa treats different spaces within the whole context of Querini Stampalia is interesting to note. He unconventionally brings together different materials and forms which is something to learn from and be influenced by when detailing the proposed intervention for the my Sanctum space.

Louis Kahn is another architect who conveyed sacred qualities in secular function buildings and is known for his poetic approaches to architecture. One of Kahn's notable works which show case water, is the Salk Institute for Biological Studies in La Jolla, California. He described his design for the institute as "the thoughtful making of space" as the planning and arrangement of spaces is meticulous. ${ }^{11}$ In contrast to Scarpa, Kahn takes materiality to a single tone and focuses on minimalist form. (Fig. 51) Water channels along the centre of the open plaza emphasising the symmetry between the buildings on either side of it. (Fig. 52) The strip of water runs towards the Pacific Ocean which directs the attention of inhabitants towards nature. The square forms are 
simple but the composition and the arrangement is quite complex. ${ }^{12}$ (Fig. 54) Through this manipulation of form and water, Kahn materialises a sense of spiritual awareness where the form itself transcends its function. Analysing his methods of formal composition will be useful in my design experiments in creating meaningful spaces which work harmoniously and respond to each other as well as to the site.

Water is important to religion and spirituality and can be directly used in architectural interventions as seen in the work of Scarpa and Kahn. In both cases, the element of water is almost purely decorative yet evokes sacred and transcendental atmosphere in the space. Querini Stampalia and Salk Institute are examples of landscape interventions which project this feeling of peace and serenity. The techniques used by both architects to achieve this sacred quality will be interpreted and followed through in the stages of my design process in order to enable the Sanctum to be universally appreciated. 


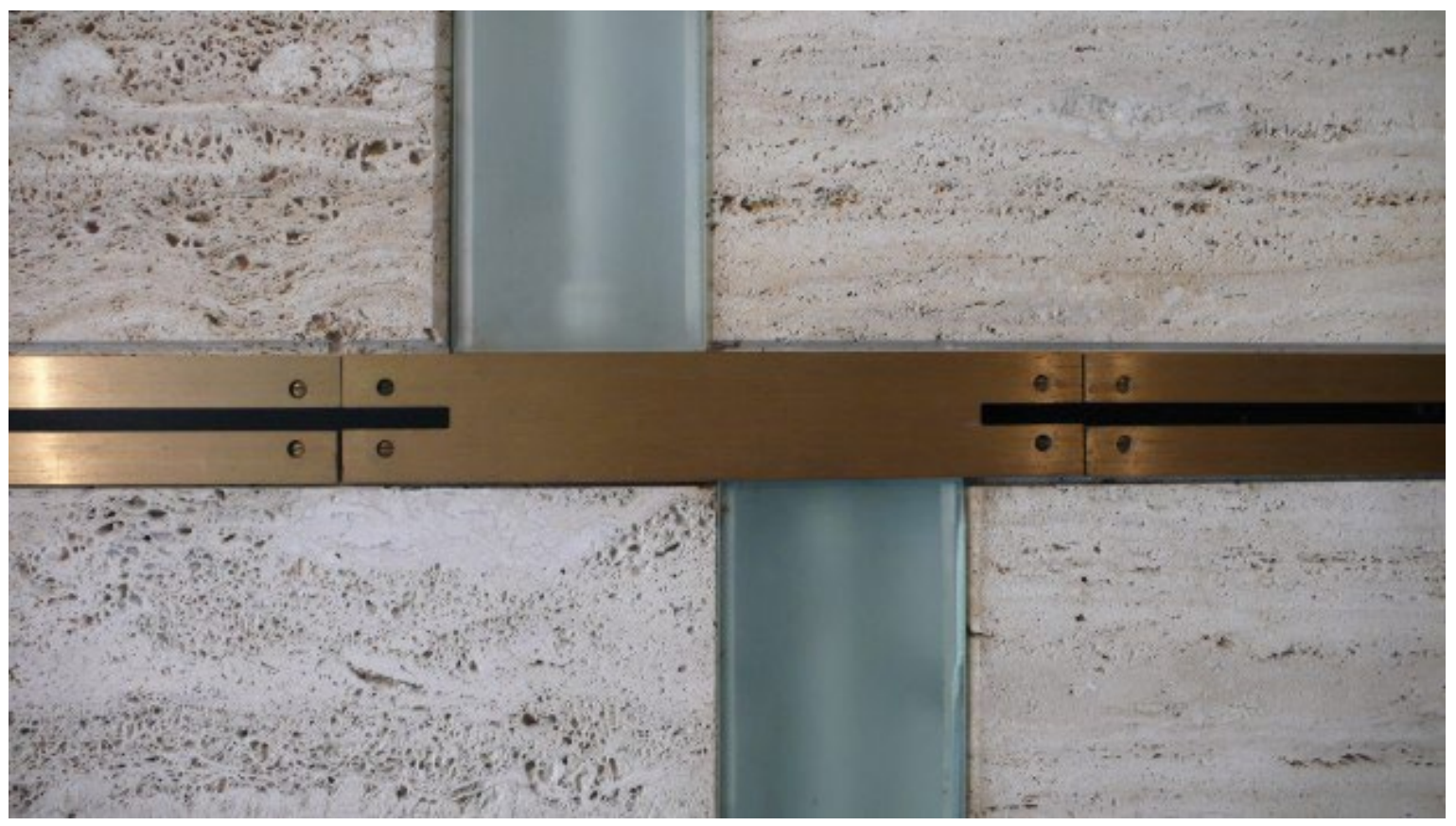

Figure 46) Detailing of various juxtaposed materials in interior of Querini Stampalia

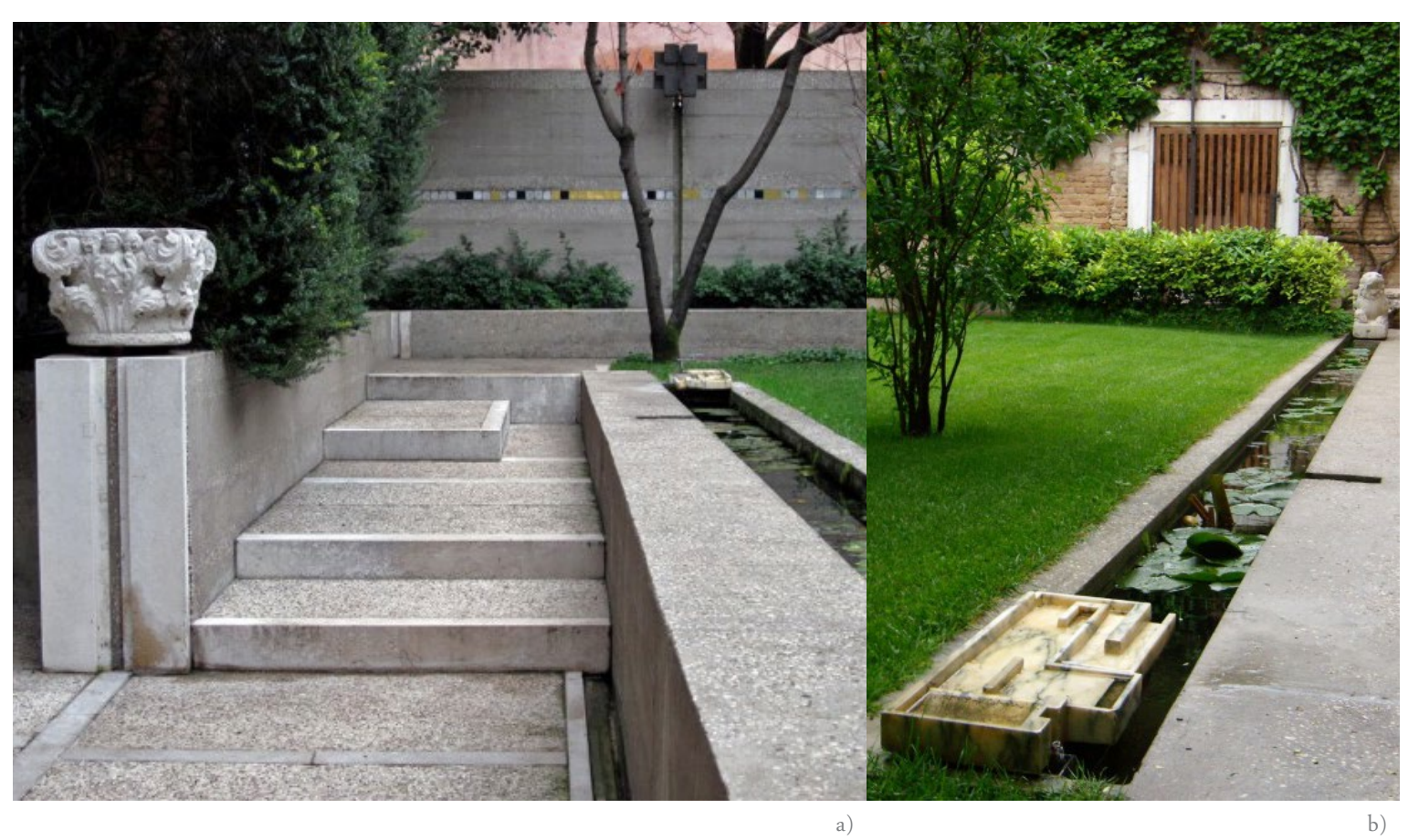

Figure 47) Marble and Stone steps (a) with water trail (b) in the garden of Querini Stampalia 


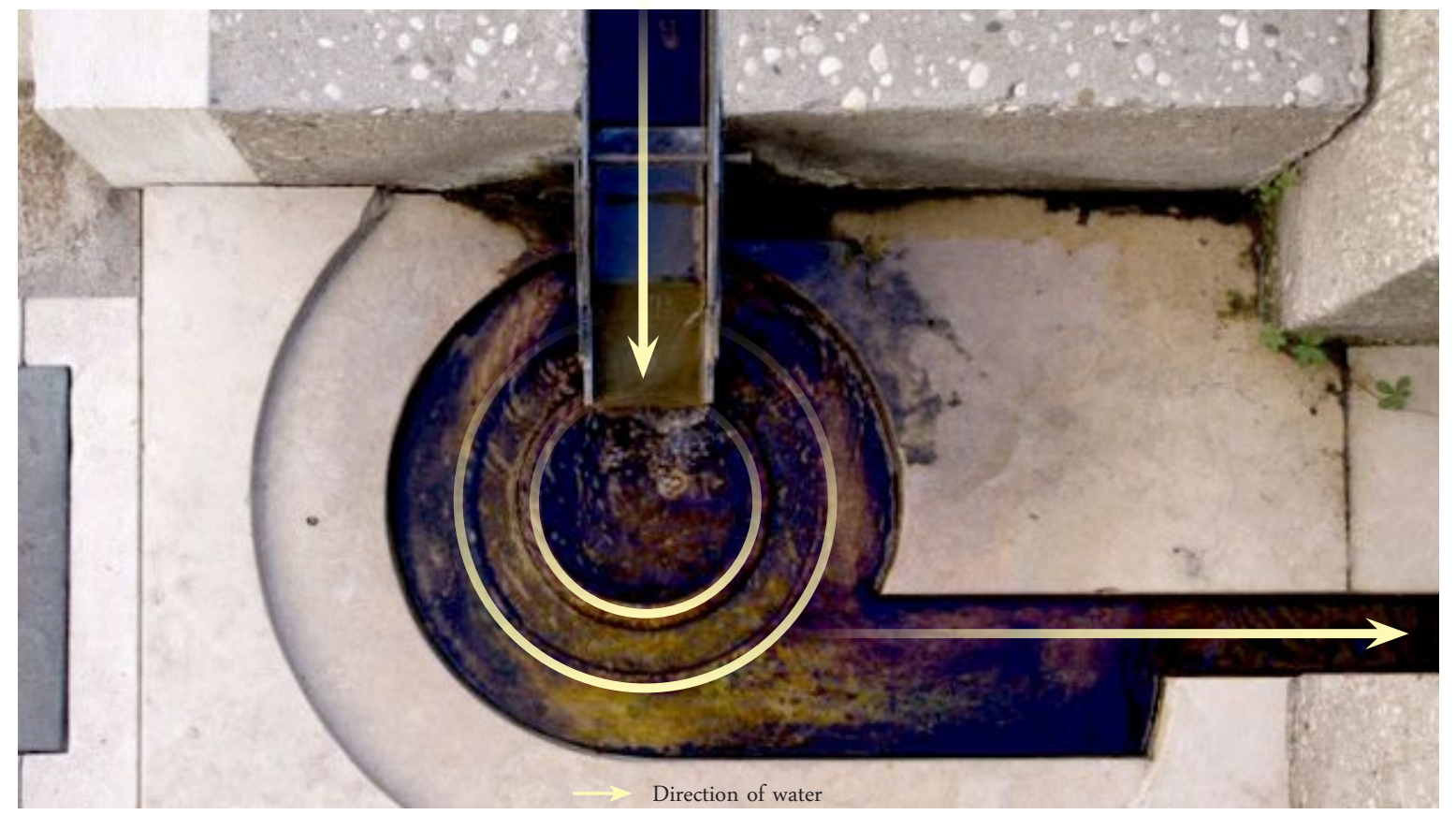

Figure 48) Circular water feature - Sacrpa's design symbolically articulates and expresses the natural flow of water

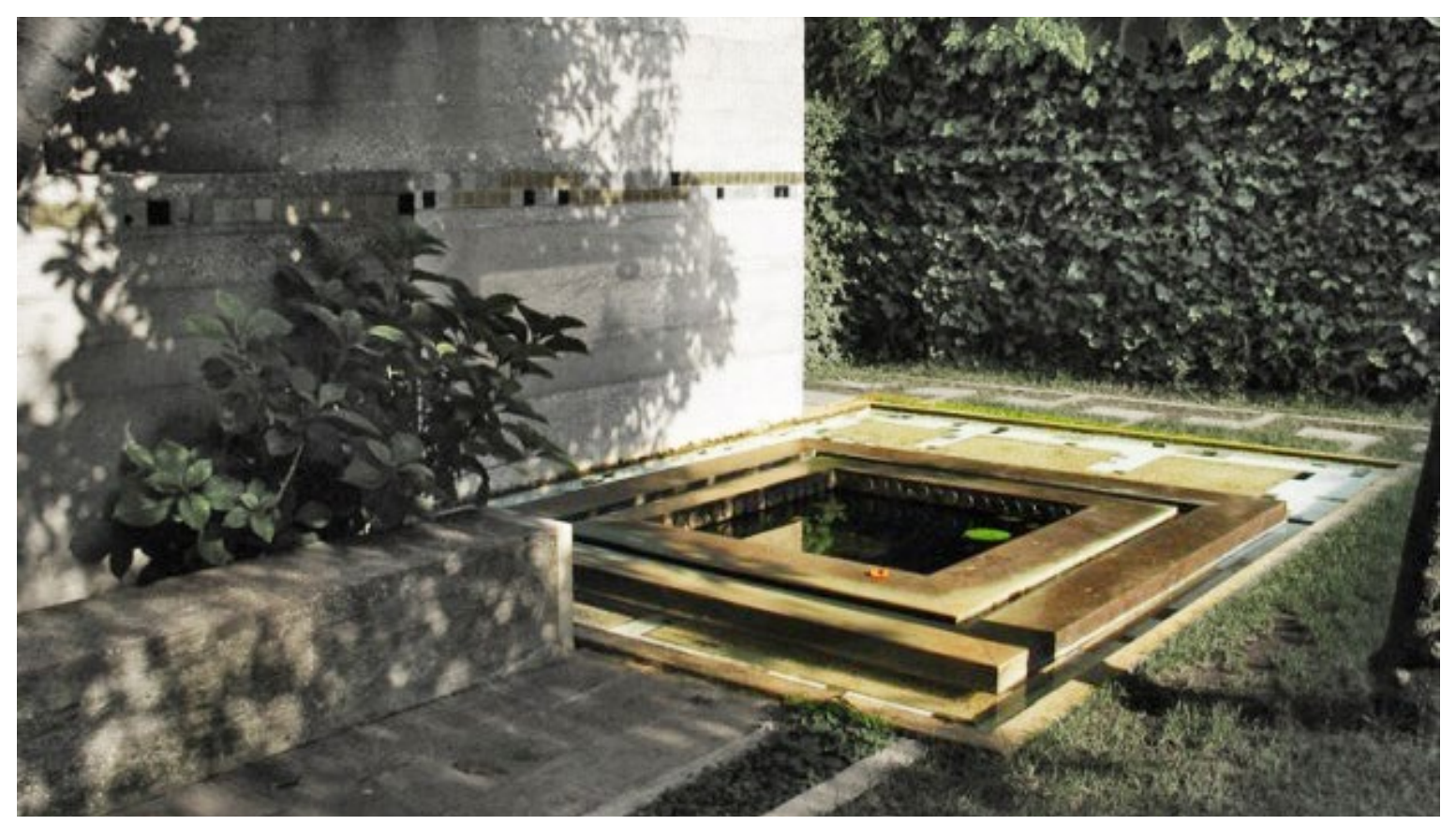

Figure 49) Highlighting Square form pond embedded in the garden 


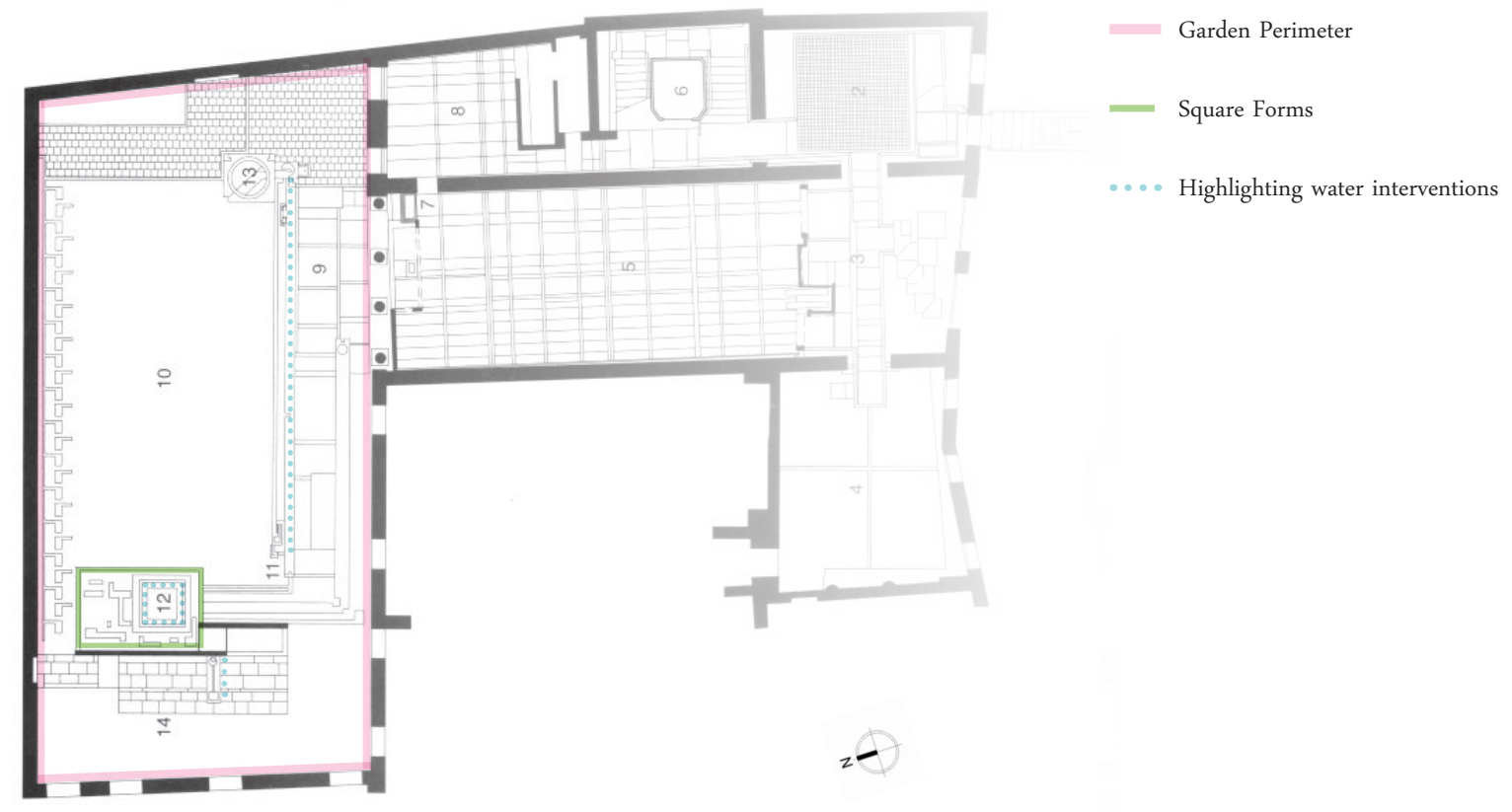

Figure 50) Plan drawing of Querini Stampalia, diagramming features of the garden

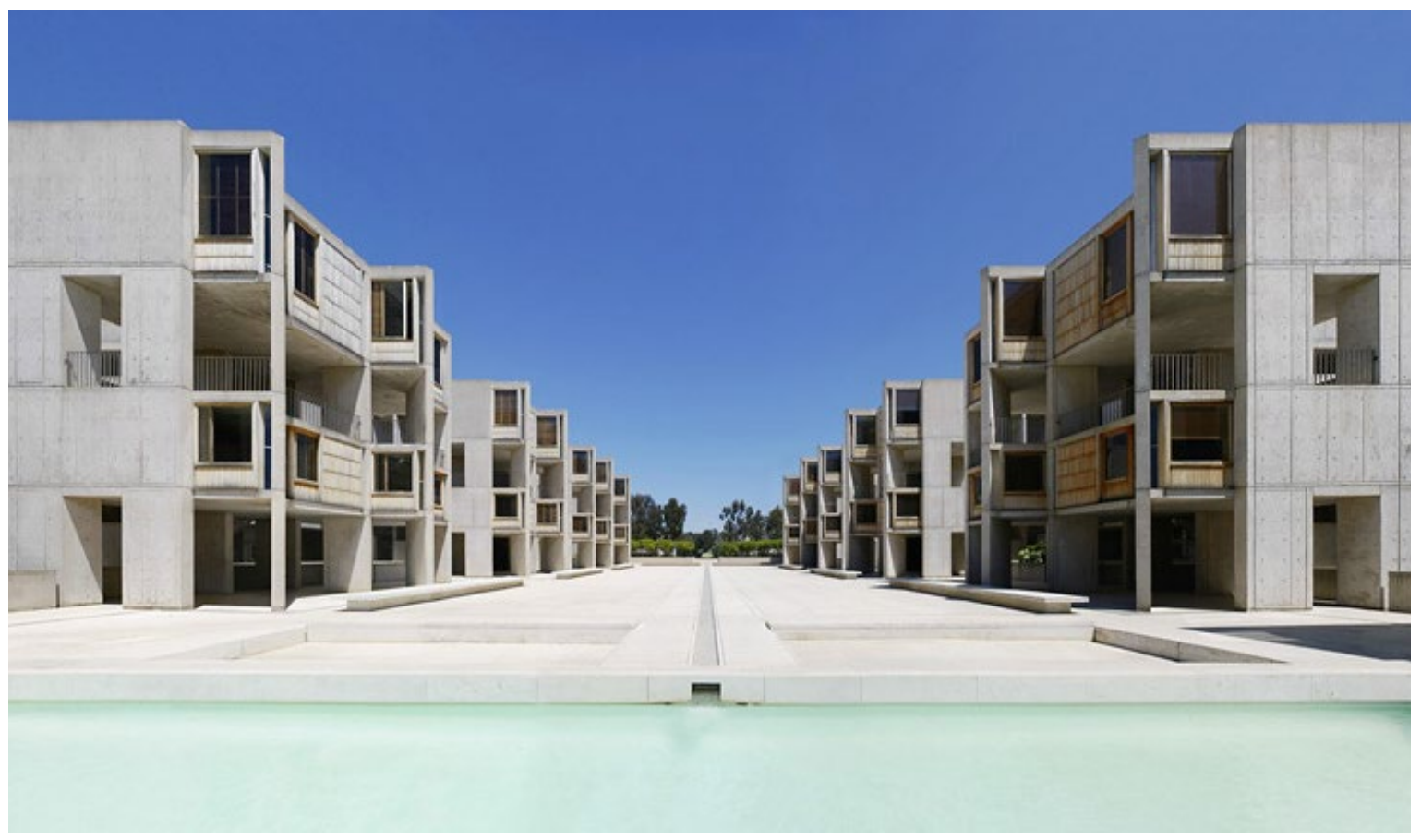

Figure 51) View of Kahn's Salk Institute (entire building), showing the use of Neutral toned materiality 


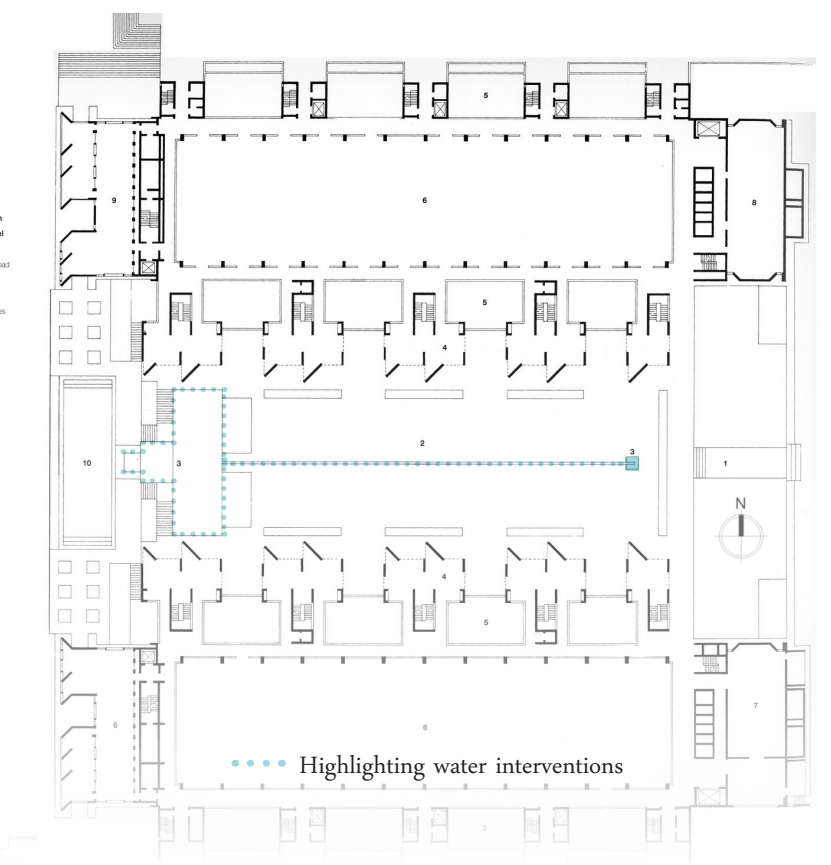

Figure 52) Plan drawing showing water intervention in the Salk Institute

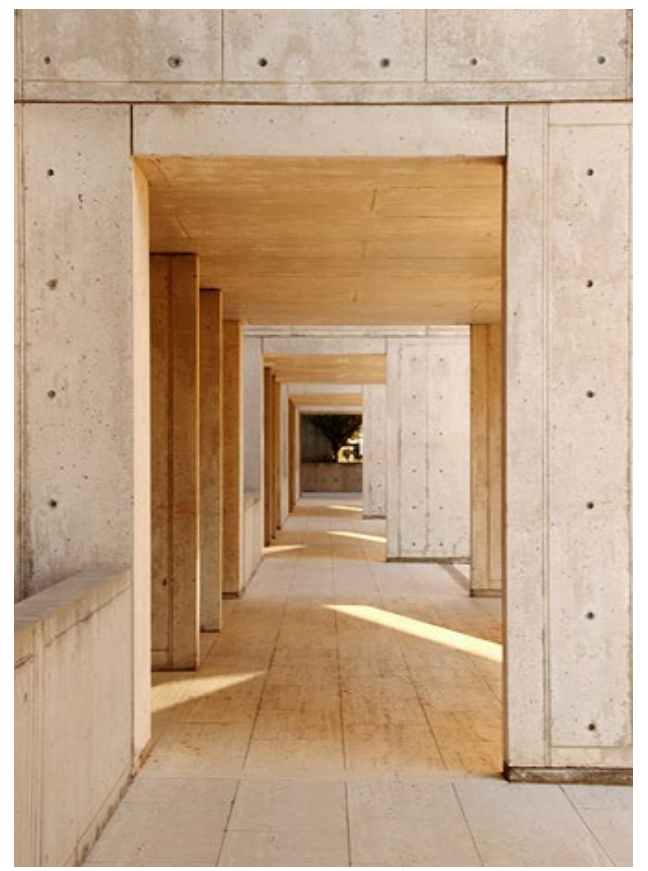

Figure 53) Interior of passageways of the Salk Institute

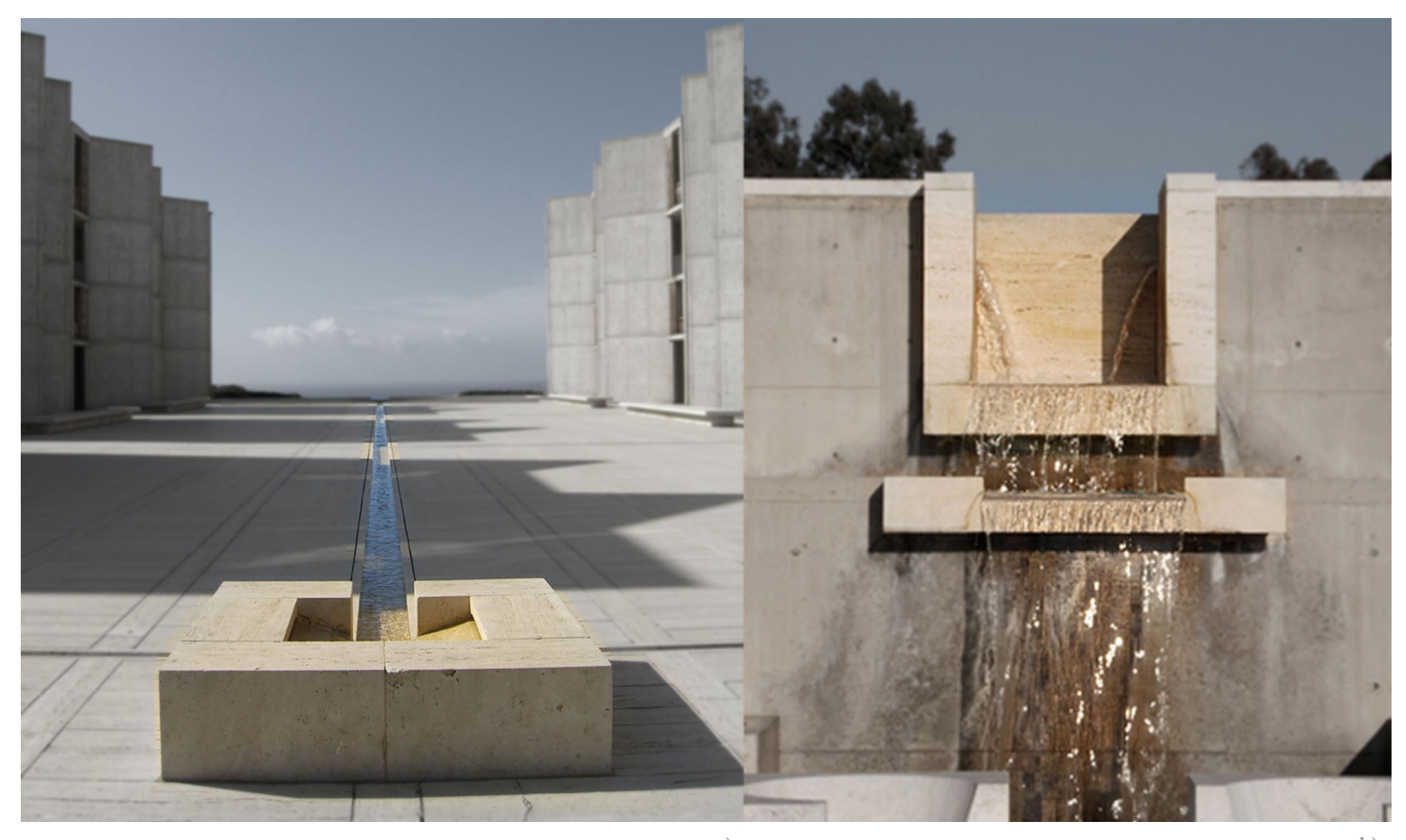

a)

b)

Figure 54) Highlighting the Square forms of the water trail which draws towards the ocean (a) and the fountain at the end of the trail (b) 


\subsection{EARTH \& SKY -}

Comparisons between The Pantheon and James Turrel's Skyspace installations.

Religious spaces often reference the four classical elements (Earth, Water, Fire and Air) and celestial symbols through architectural gestures. Traditionally the Earth and Sky illustrate the difference between humans down on earth and gods in the heavens above. ${ }^{13}$ The great Pantheon of Rome is an ancient example of this illustration. An understanding of the architectural qualities in the Pantheon, used to evoke sacred atmosphere, is imperative for this thesis. One of the key aims in this thesis is for the Sanctum to be a contemporary manifestation. James Turrell's Skyspace are contemporary design installations will be analysed comparatively with the Pantheon as they both convey similar architectural qualities which produce sacred space.

The Pantheon has long been regarded as a great example of architectural engineering and design which has stood the test of time. Architects and academics from all over the world have learnt from and been inspired by this temple. The Pantheon literally translates to a 'temple for all gods' and its present structure was completed by Emperor Hadrian and his architects 126 AD. ${ }^{14}$ An interesting point to note is that Hadrian's intention for the Pantheon was that it could be used by anyone to worship any god and not restricted to certain priests. It was one of the first examples of an ecumenical space which has influenced many religious buildings in modern architecture. $^{15}$

${ }^{16}$ MacDonald, W. L. 50 -55, 89 -91

${ }^{17}$ Adcock, C. G. \& Turrell, J.

$117-121$ the shape of a sphere as the height of the space is equal to the diameter of the dome being 43 metres. (As seen in Fig. 14) The round quality of the dome is seen as the perfection contrasted to the rectangular portico entrance. The dome has an opening at its peak which lets natural day light into the large space. This gap is called the oculus which draws the attention of visitors upwards to the light. This architectural feature invokes spiritual qualities as the notion of looking upwards and accentuating the height of the space reinforces the idea of looking to the heavens from earth. (Fig. 55)

The solidity of the earth contrasted to the eeriness of the sky is revealed in the architecture by the use of stone and heavy material around the bottom of the structure which progressively becomes thinner and lighter towards the top of the dome and eventually becoming the open oculus. ${ }^{16}$ (Fig. 56) This method works to structurally stabilise the space as well as adds to the design intention. The oculus as a simple round skylight is an interesting feature of the Pantheon which allows visitors to feel a connection to the sky. This can be influential to this thesis in suggesting spiritual qualities.

James Turrells's Skyspace installations can be seen as contemporary expressions of the oculus in the Pantheon. Skyspace is a room or a space with a hole in the ceiling opening up to the sky. (Fig. 57 and Fig. 58) Turrell's installations incorporate LED lights which fill the room with different colours creating a powerful ambience. (Fig. 59) The single skylight in the minimal space draws the attention of viewers upwards to the sky evoking meditative thoughtfulness. ${ }^{17}$ Turrell uses pure light to inform his design which makes viewers experience the feeling of light itself. 
He explains that he aims to create spaces in which viewers observe themselves seeing.

"With no object, no image and no focus, what are you looking at? You are looking at you looking. What is important to me is to create an experience of wordless thought." 18

The use of minimal materials and lighting technology, the skylight in Turrell's installation achieves similar atmospheric qualities as the oculus in the Pantheon in a contemporary manner. Turrell's work is not intended to be specifically religious but can interpreted as contemporary way of looking at spiritual architecture. The techniques Turrell uses in his installations successfully engages with anyone who experiences them.

Analysing both ancient and contemporary examples is useful to this thesis topic as the concept of religion and spirituality relates to anyone from any era. Both the Pantheon and Turrell's Skyspace show how the skylight as an architectural figure can be effectual in creating a sacred space as it connects the interior space with the sky symbolising a connection with heaven or with our inner spiritual side.

\subsection{Conclusion}

The intention for my design, Universal Sanctum, is to be a contemporary space which can be felt sacred and transcendental by anyone. The analysis of the examples above are useful in the process of the design as they all display methods of creating sacred atmosphere without specifically referencing religious motifs.

The analysis from Ando's Water Temple and Safdie's Jewish Museum will help to inform my overall intervention and the formal composition of spaces in relation to the site as well as translating a sense of journey in the intervention. The manipulation of water to evoke sacred atmosphere is successful in the work of Scarpa's Querini Stampalia and Kahn's Salk Institute because of the way in which the water is channelled emphasises the detailing of materials and forms. These techniques will be adapted to the site context in the process of my design. Finally, the symbol of heaven or spiritual power is present in both the Pantheon and Turell's Skyspace by the use of the oculus or opening in the ceiling. Having a connection to the sky in my intervention will be necessary in lighting the space with natural daylight as well as reinforcing the idea of drawing one's attention upwards which is a common feature found in sacred spaces.

Analysing theses specific examples is crucial to understanding sacred spaces in general, because they provide an expression of the theory examined in the literature review.

This will help to inform my design decisions which will in turn create a successfully space with the intention of being acknowledged as sacred by anyone who visits. 


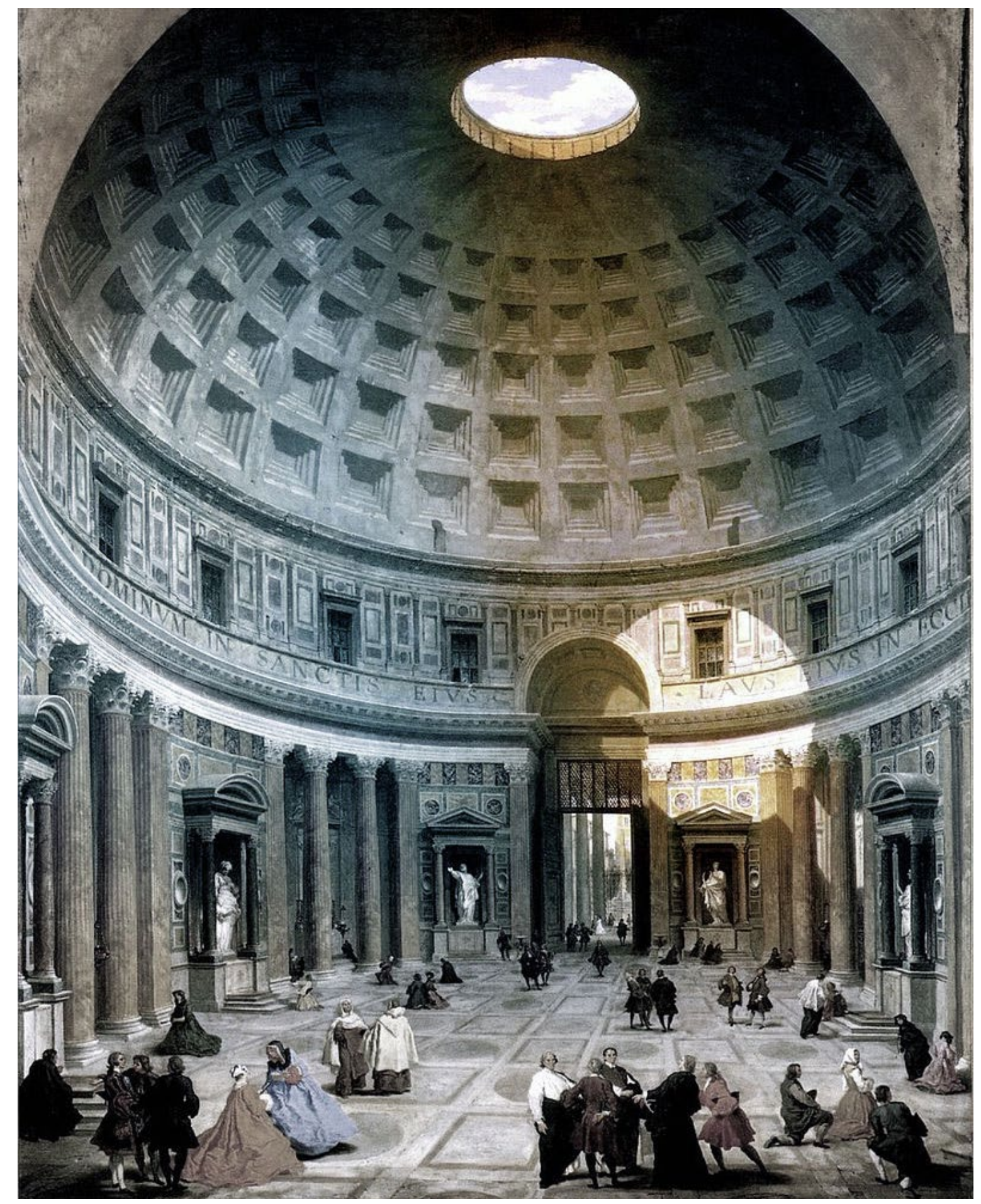

Figure 55) Interior view of the Pantheon showing light beam from the oculus - visual connection to the heavens above 


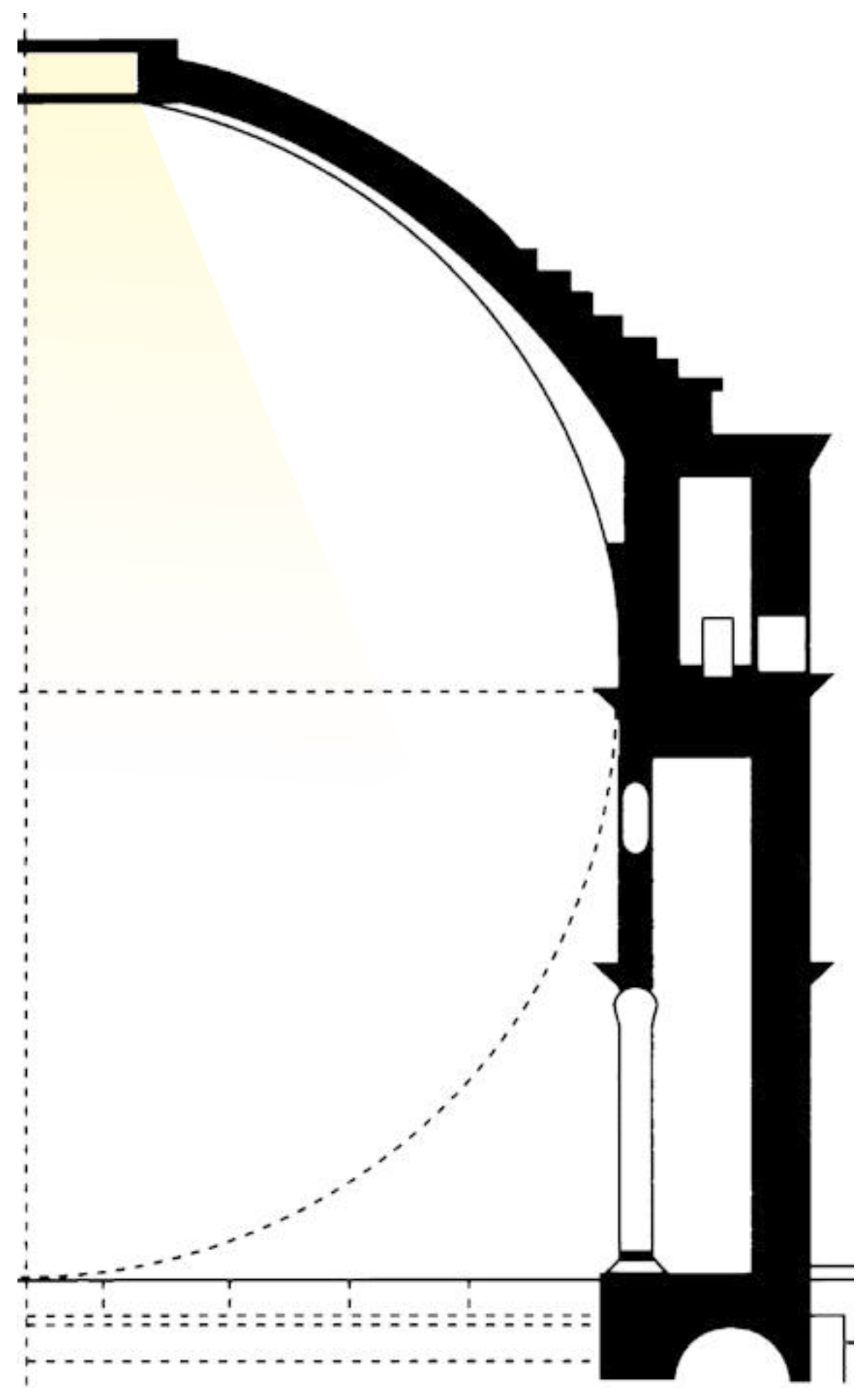

Figure 56) Section drawing analysing the direction of light through the oculus from the sky 


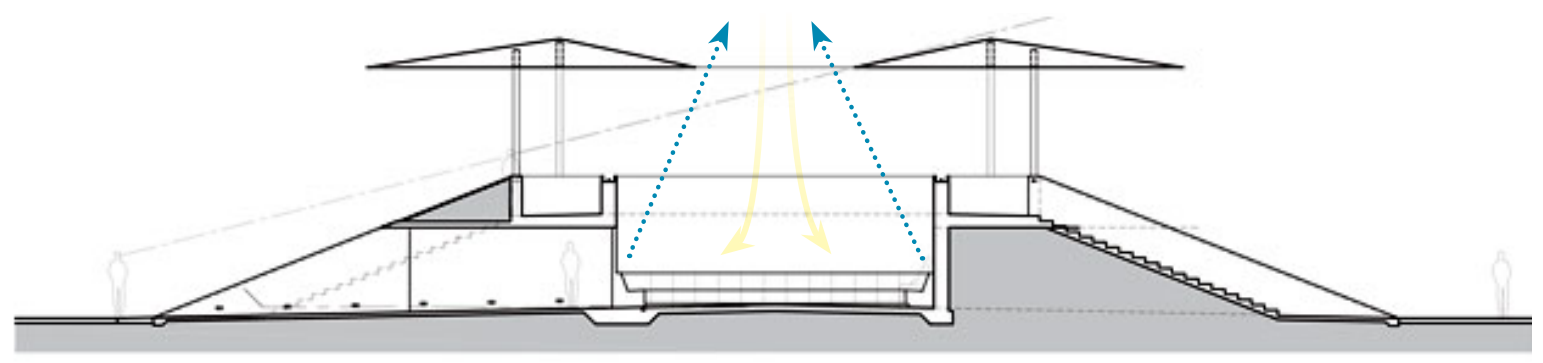

Sunlight/Moonlight

$\cdots>$ Line of sight - vision of the sky

a)

Figure 57 a) Skyspace 'Twilight Epiphany' at Rice University, Houston, TX: Section drawing analysing sight lines to the skylight

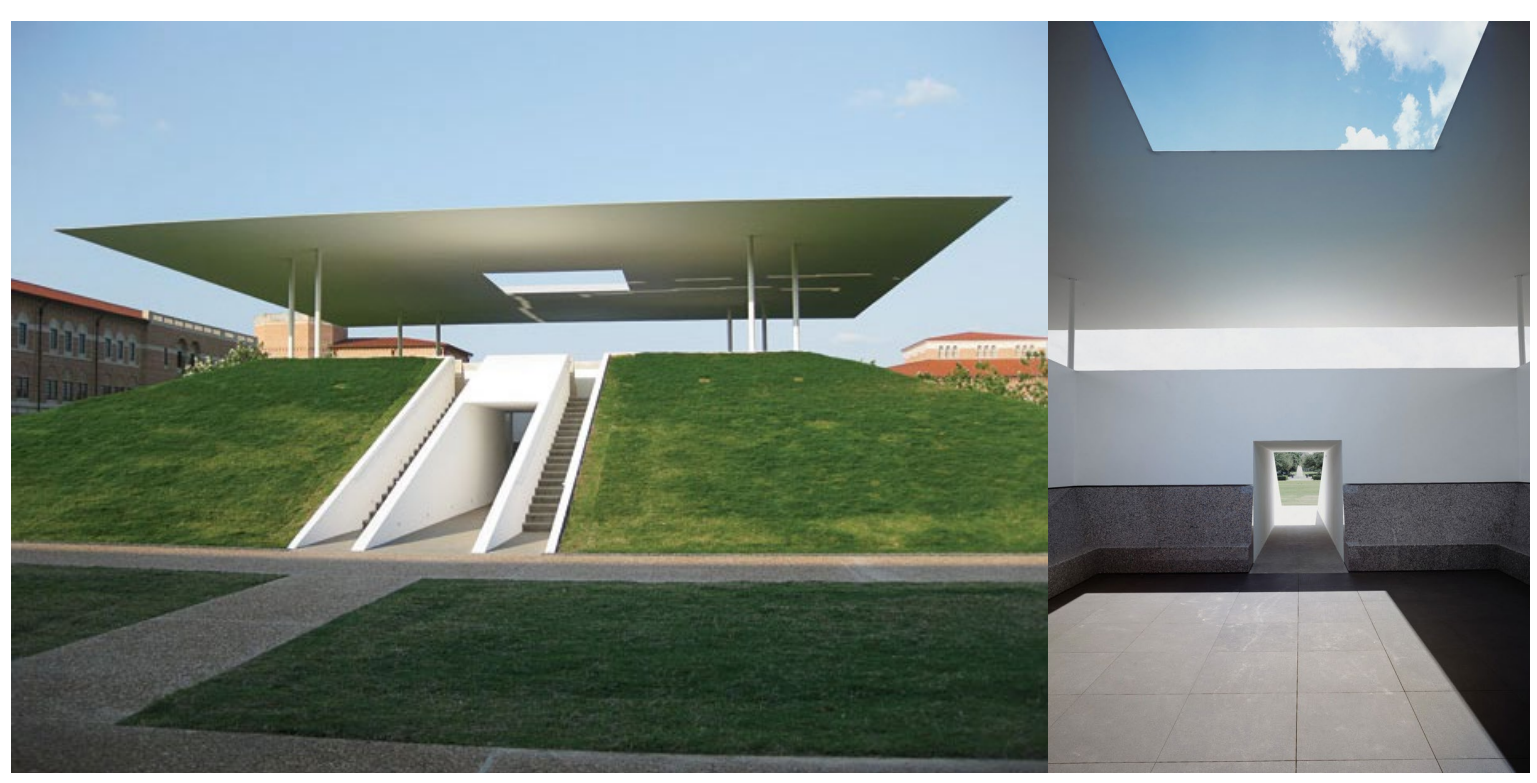

a)

b)

Figure 58 a) 'Twilight Epiphany' exterior view of the installation and b) interior daylight through the skylight 


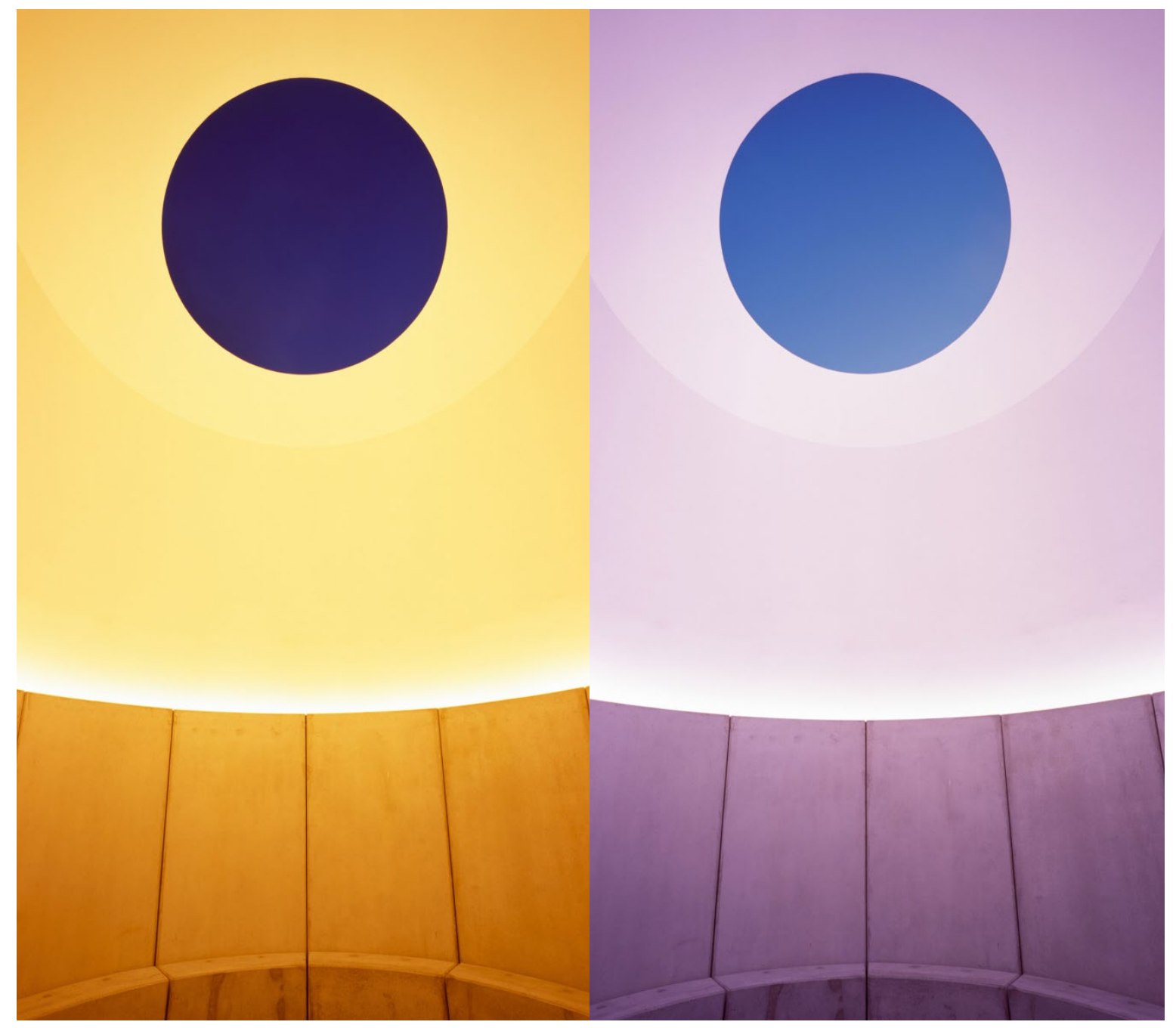

Figure 59) Skyspace 'Third Breath’ at Centre for International Light Art, Unna, Germany: Interior with various coloured LED lights 
CHAPTER SIX 


\section{PRELIMINARY DESIGN EXPERIMENTS}

\subsection{Introduction}

This section follows the initial stages of design experiments, reflecting on thought processes which influenced design decisions. The strengths and weaknesses of each phase is analysed according to the initial aims and objectives of my research.

\subsection{Paper experiments}

These experiments were conducted during the early stages of research into precedents and gathering the general information from theoretical literature. These models explore light qualities through thin slits of organically folded paper. The resulting shadows and forms give a sense of delicateness but do not provide spatial means or relevancy to site and programme. However this exploration is useful for the early stages as it helps to determine the intended design language to be pursued in this thesis. (Fig. 60)

6.2 Site Diagramming and Programmatic schemes - Initial Stage

The site diagrams explore the existing forms of the site and potential opportunities for generating structure and space. The sketches in plan, illustrate abstracted composition of simple shapes from which structure can emerge. The orientation of spaces are drawn out against the natural topography and the directions of the site, the sun, and the wind.

The division of spaces is based off general research of inspiration and precedent images of contemporary sacred architecture. The intention of this thesis is to be universally encompassing anyone from any religion, so as per the scope of research, the intervention cannot attend to specific rituals associated with each of the religions. Universal concepts such as composition, journey, nature, discovered in the theoretical research and case studies, are considered in the planning of these spaces. (Fig. 61 and Fig. 62)

\section{ENTRY}

The entry to the Sanctum is important to the overall intention of the space as it will act in a way which embraces all people regardless of background and draw them to the interior.

\section{CENTRE}

The central space will have an architectural feature which draws focus to the centre. This space will be like an anchor point from which the other spaces stem from.

\section{INNER SPACES}

Smaller, singular spaces will be beneficial to the scheme as it will provide an interior for meditation or for individuals seeking quiet space. The architecture itself drawing light into a small corner or an alcove space will facilitate for this programmatic requirement.

\section{EAST and WEST}

According to previous analysis, all religions and cultures revere the cosmos and the natural elements, thus organising spaces to the direction of the sun will set up a neutral atmosphere. This will in turn balance the Sanctum through composition and programme. Congregation or communal spaces will be created for both East and West wings which open to the light of dawn and witness the light of dusk.

VIEW

The site in Mount Victoria has incredible views of the harbour and the city which should ideally be taken advantage of. Architecturally framing these views will enhance the space bringing nature into the space and inducing calming qualities needed for self-reflection. 

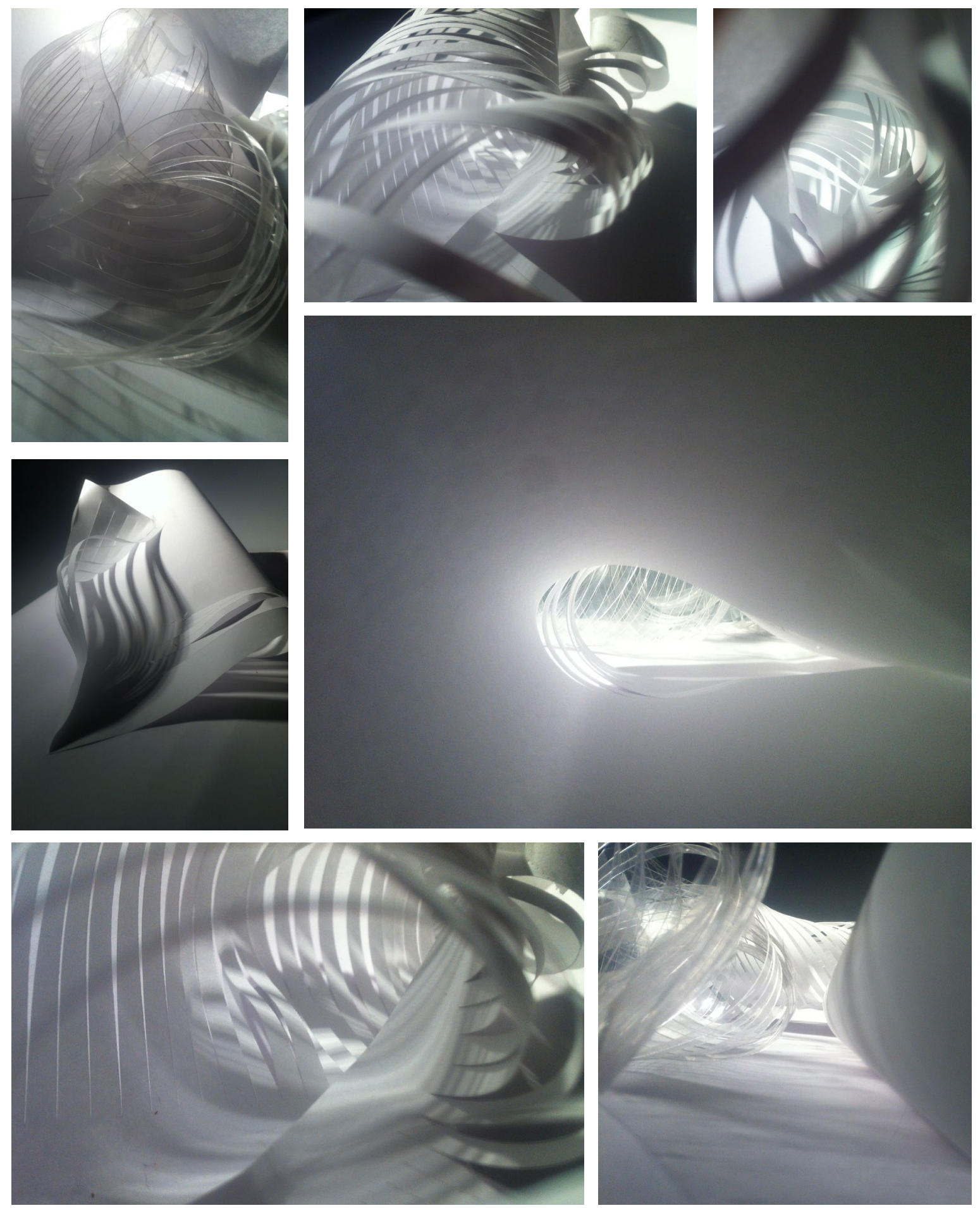

Figure 60) Photographic composition of initial paper models showing potential spatial light and shadow qualities and organic structure 


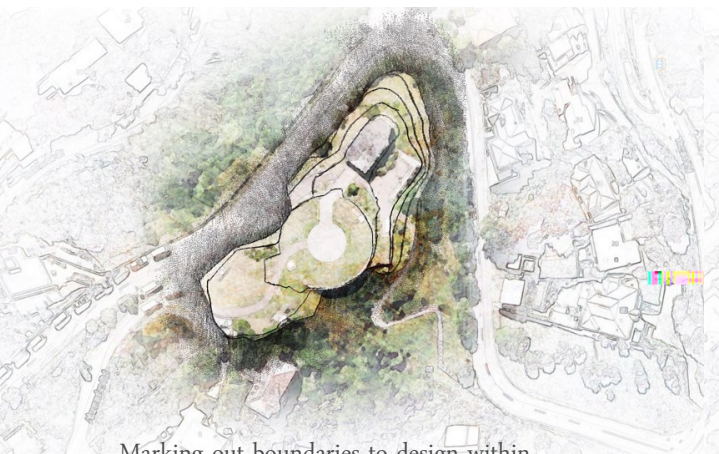

Marking out boundaries to design within
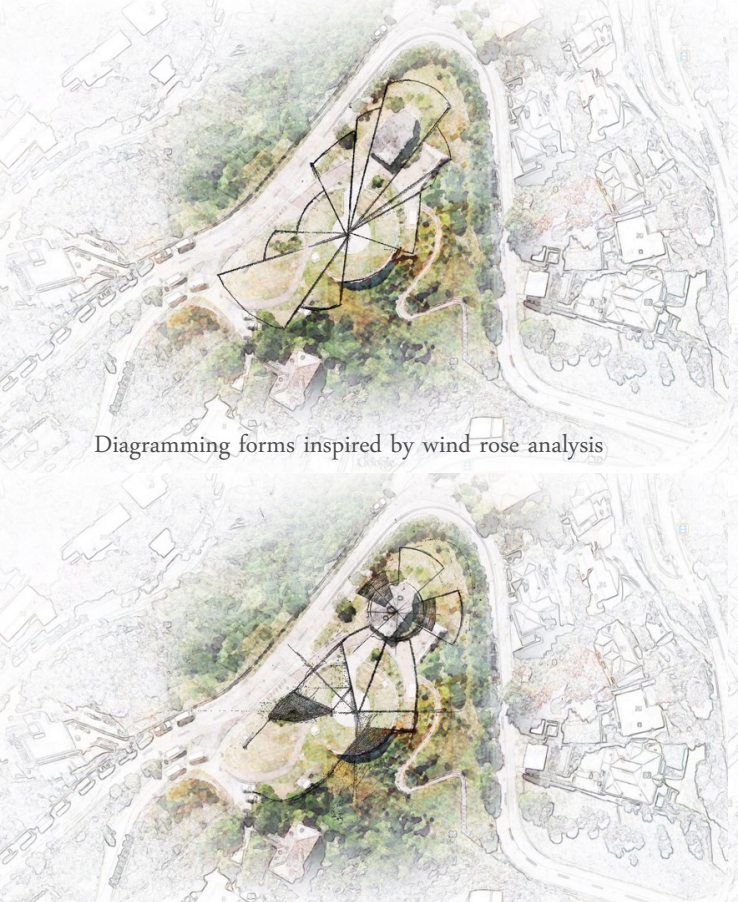

Diagramming initial forms for potential spaces

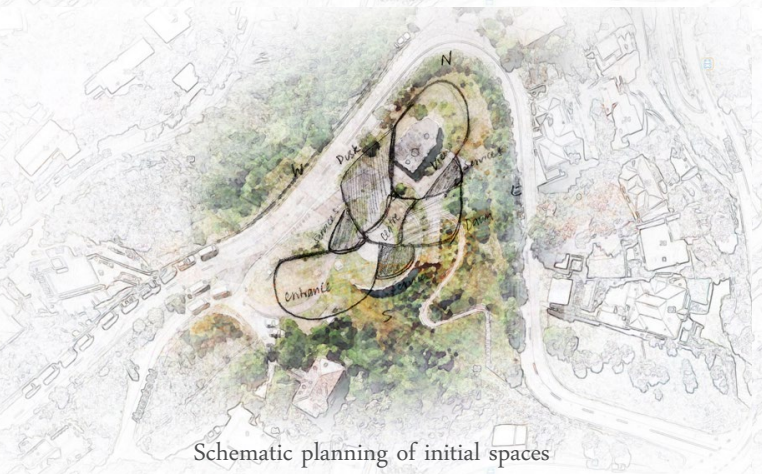

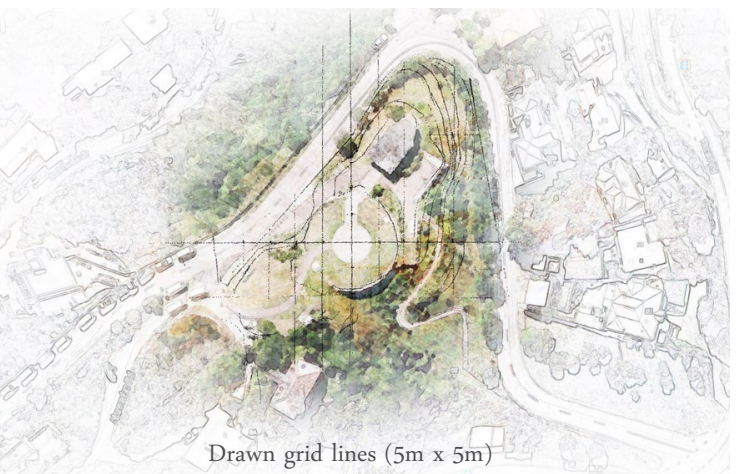

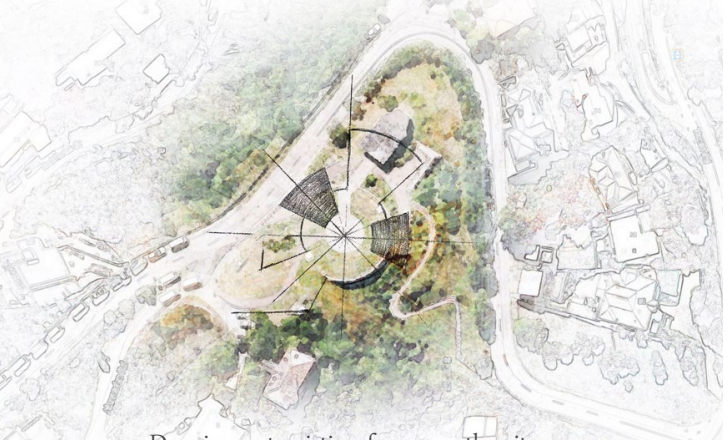

Drawing out existing forms on the site

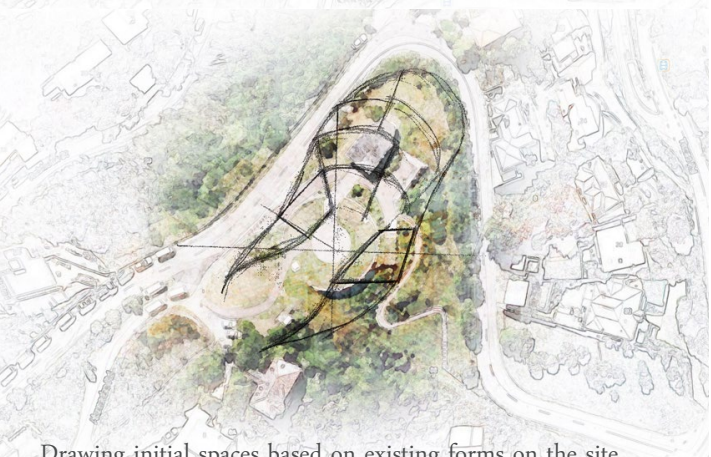

Drawing initial spaces based on existing forms on the site

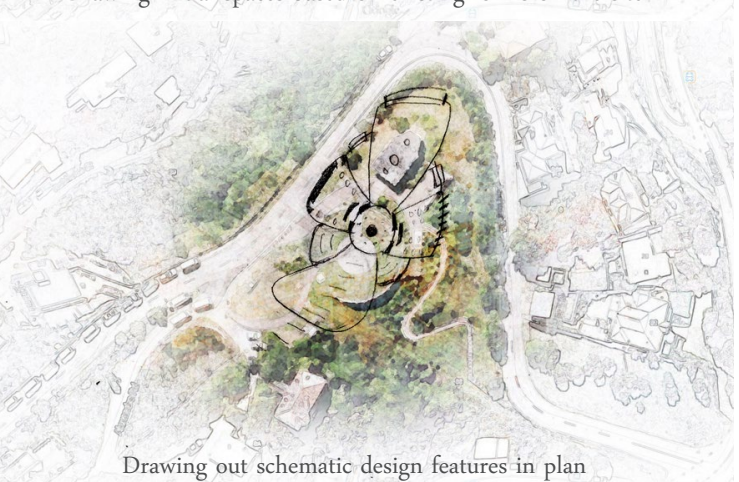

Figure 61) Site drawings in plan 


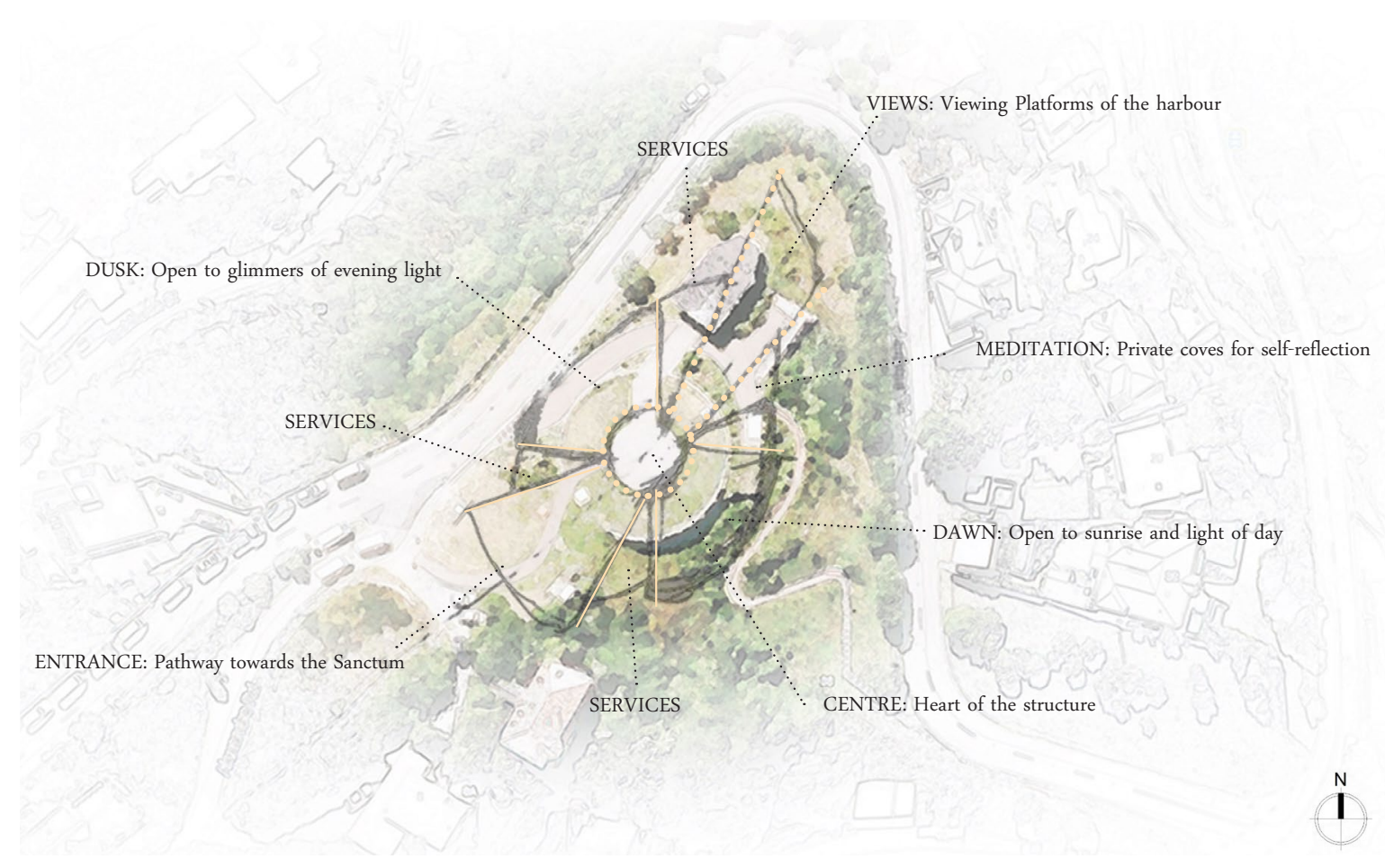

Figure 62) proposed program of spaces on site

6.3 Matrix of spaces with aesthetic qualities

Following from the initial programmatic schemes as seen in the drawing above, a matrix of precedent images was developed to illustrate desired spatial and architectural qualities which could prompt the design of these specific spaces. (Fig. 63) 


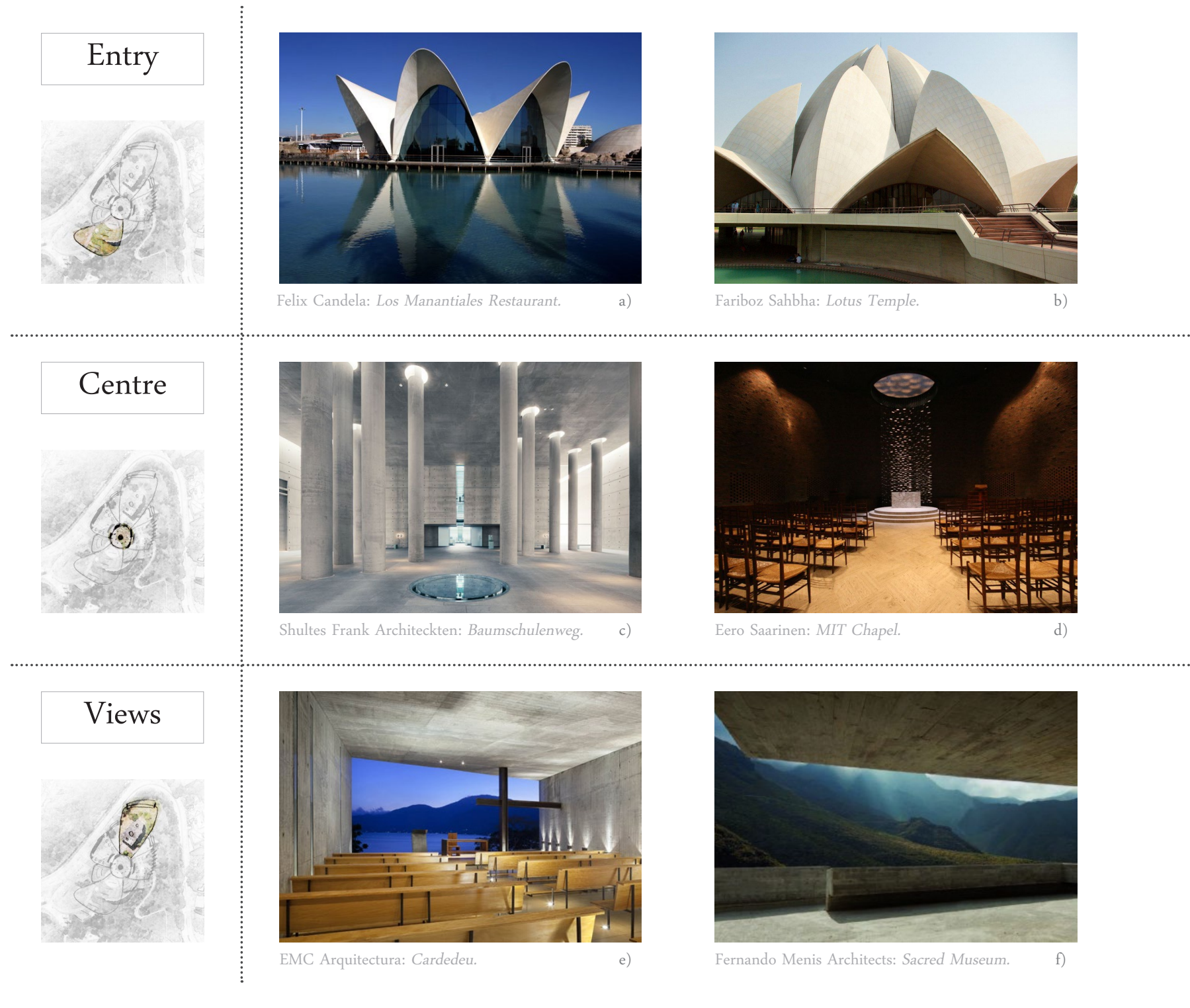

Figure 63) Matrix of Architectural Examples found to express desired qualities for each space mapped out in programmatic scheme drawing. 


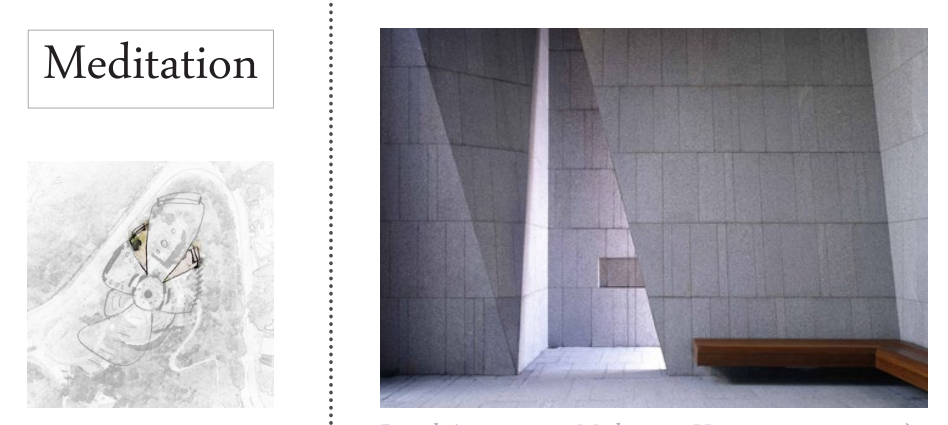

Pascal Arquitectos: Meditation House.

g)

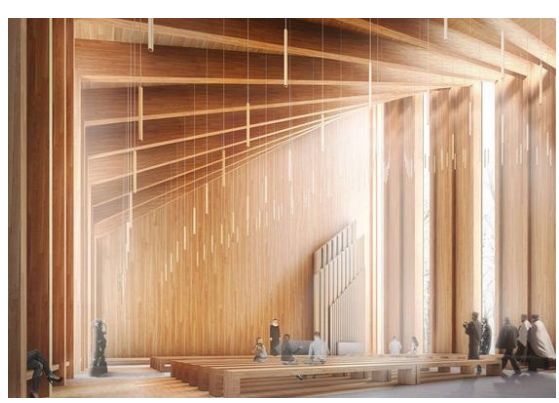

Konrad Wójcik: Hatlehol Church (concept). i)

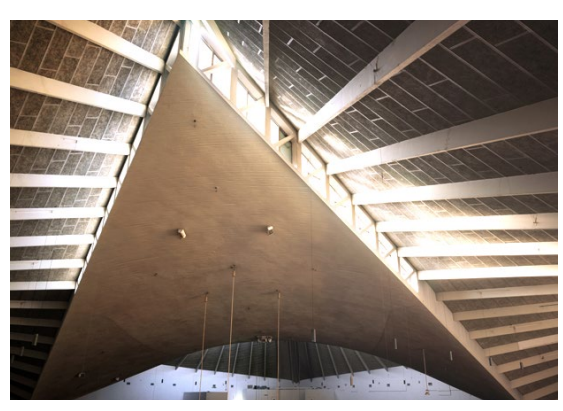

RMJM: The Parabola (Commonwealth Institute). k)

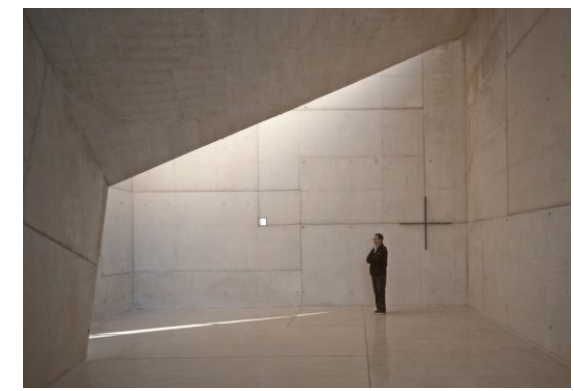

S.M.A.O: Chapel in Valleacerón.

h)

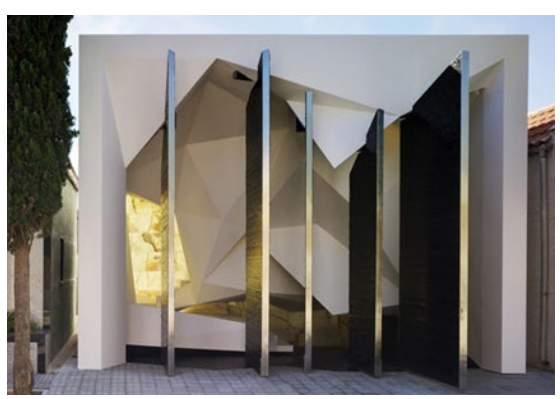

Clavel Arquitectos: The Panteón Nube.

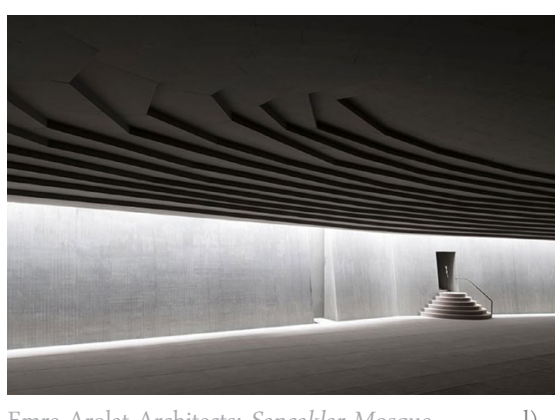

Emre Arolat Architects: Sancaklar Mosque. 1) 
6.4 EXPERIMENT ONE: Parabolic architecture encompassing religions

The proposed site has no existing architecture to work with so there needs to be a way to establish an intervention. To initiate the design process, a series of form-finding experiments were carried out as a way to understand the best structure suited for the programmatic requirements. These design experiments looked at how the exterior form could be the reflection of the interior spaces. Referencing the tensile concrete structures of Felix Candela and Eladio Dieste, as well as considering the organic forms of the initial paper models, led to parabolic analogue models through folded paper and digital models through various CAD software. (Fig. 64, - Fig. 67)

\section{RESULT}

result is a concentric structure with openings from all sides allowing access to the interior from any direction, symbolising inclusiveness of diversity. The apertures also provide opportunities for framing the surrounding views and allow light to enter the interior. (Fig. 68)

\section{CRITICAL REFLECTION}

The overall form is highly architectural and extending the scope of interior discipline. The design itself is at risk of submitting to the similar problems of Santiago Calatrava's Turning Torso as analysed in the literature review. The form is singularly intricate but does not engage with the surrounding environment physically, socially or meaningfully. The design also does not express a narrative journey, lending the space to feel static and objective rather than creating an experience.
6.5 EXPERIMENT TWO: Dynamic and Symbolic architecture - focusing on the central space

Taking cues from the Experiment One, this series of explorations looked at integrating the form in to the hilly environment and creating a sense of journey. Sketching and digital experiments show various potential forms which reference the Möbius, symbolising the intertwining of different cultures and dynamic movement in space. (Fig. 69) Although the design is contemporary, the result again is addressing the scheme in an objective manner. The form does not respond to the immediate setting and there is lack of consideration for the programmatic requirements.

\section{RESULT}

The issue arises when trying to articulate the different spaces drawn out in the initial diagramming stage. The Möbius experiments motivated the need to narrow down the requirements and focus on a singular space first. The central space was then explored, concentrating on specific interior qualities which was ignored in the Möbius forms. (Fig. 70) The symbolic motif of trees and 'growth of spirituality' emerged as a way to design internal columns which could morph into an enveloping space. Taking inspiration from John Scots Futuna chapel and Hironaka Ogawa's Forest Chapel, the design resulted in a monumental structure of metal trees surrounding a central pond. (Fig. 71 and Fig. 72)

\section{CRITICAL REFLECTION}

The result of this experiment is out of proportion to the existing environment. Although it experiments with qualities of light, shadow, geometry and symbolism which are important in sacred architecture, the design does not feel meaningful to the site or the contemporary 
context established by this thesis. The design is 'pretty form' for the sake of aesthetic. 


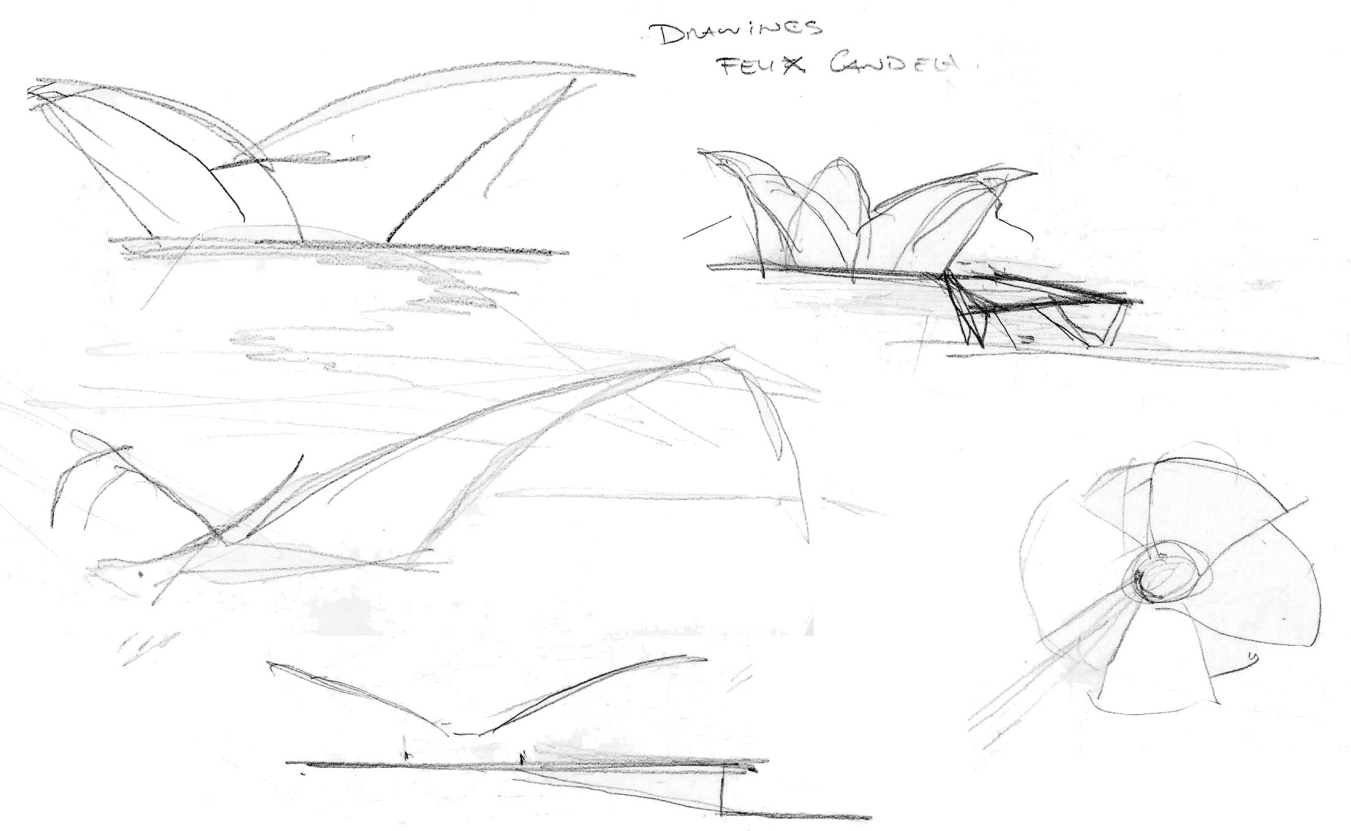

Figure 64) Sketches of initial forms which could potentially accommodate the program of spaces established in schematic diagram (Fig. 62)
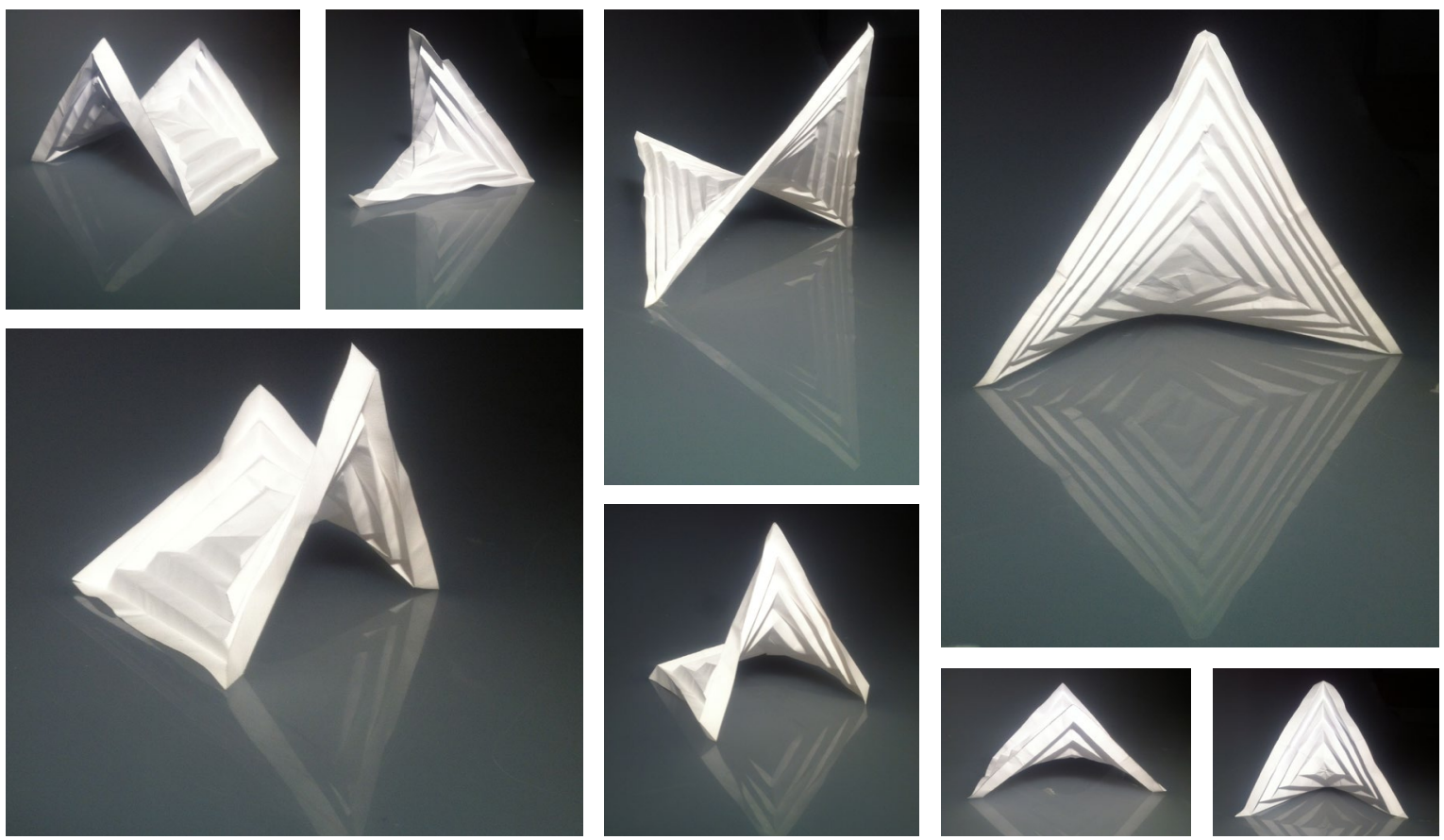

Figure 65) Understanding parabolic form through paper modelling 

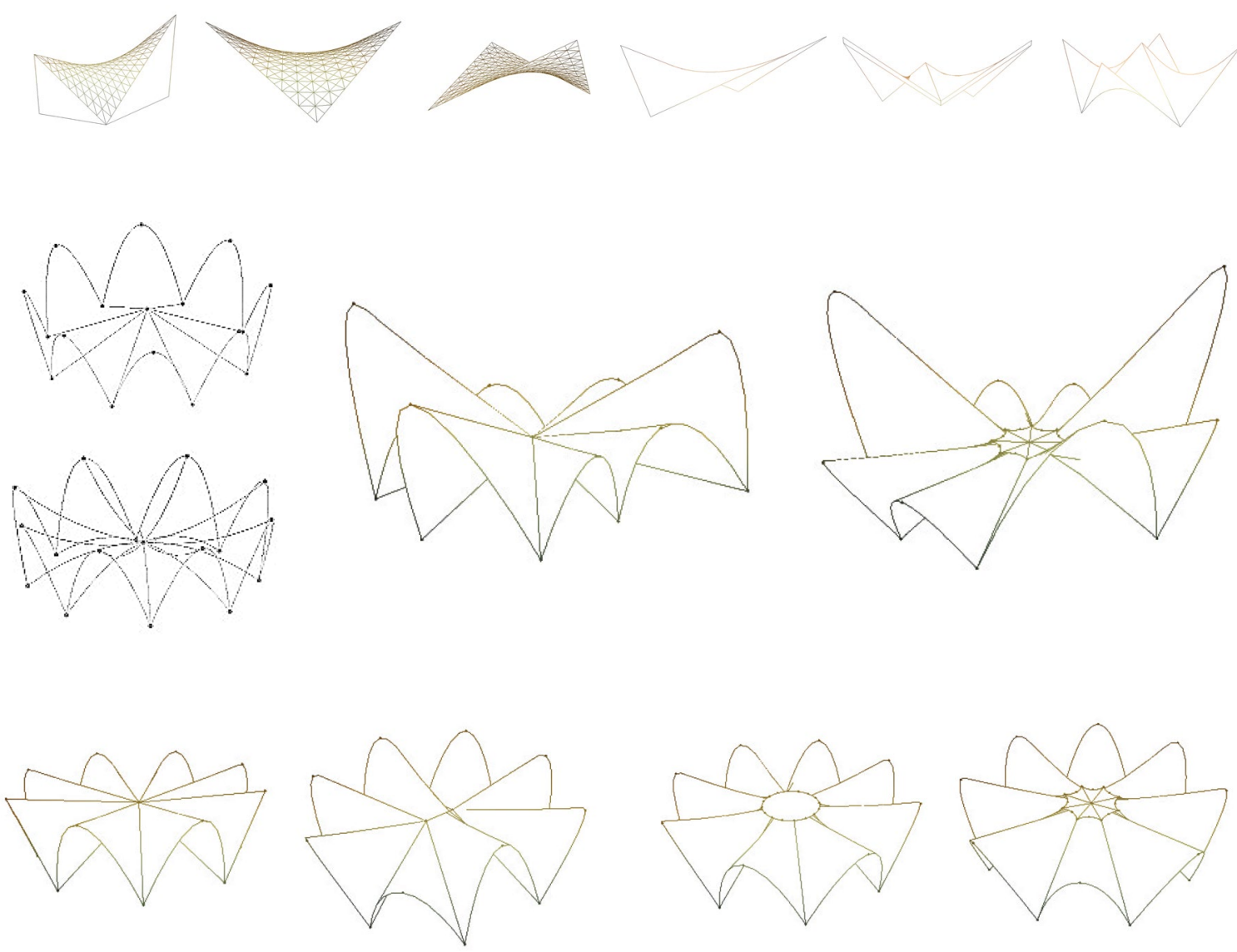

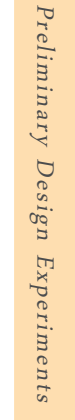

Figure 66) Understanding parabolic form through digital modelling
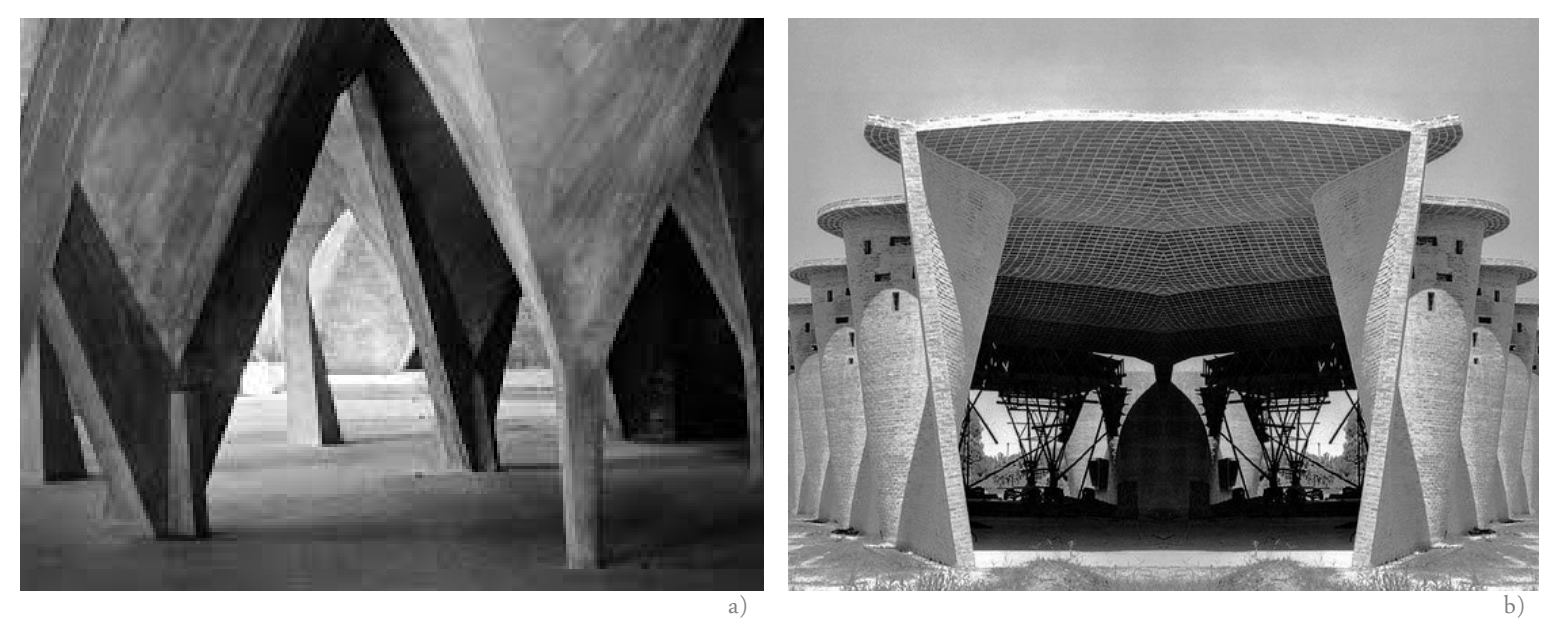

Figure 67) Parabolic architecture precedents - Felix Candela's Narvarte Church (a) and Eladio Dieste's Church of Christ the worker (b) 

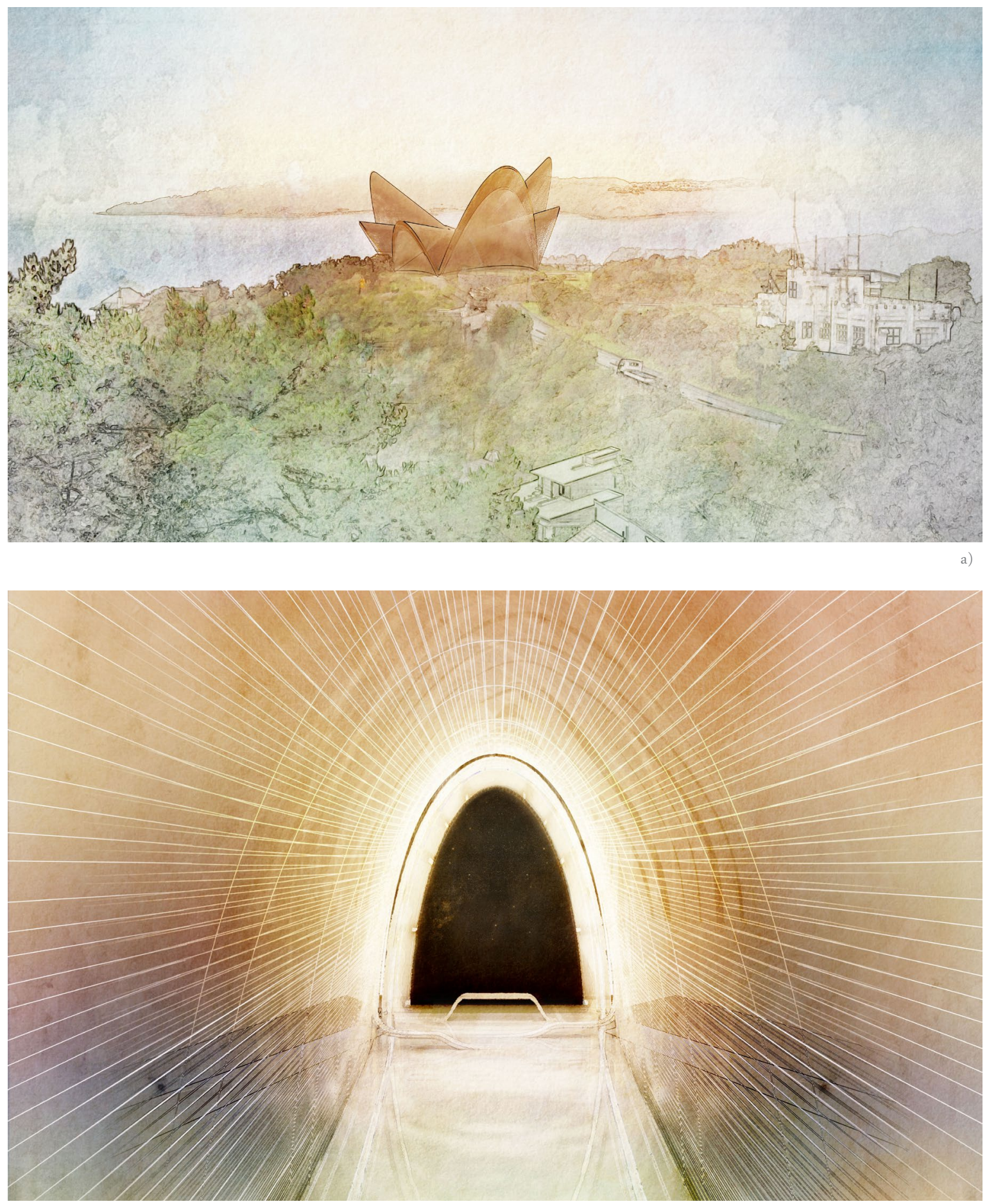

b)

Figure 68) Result of Experiment One - Exterior view structure on site (a) and Interior view of potential dusk space (b) 

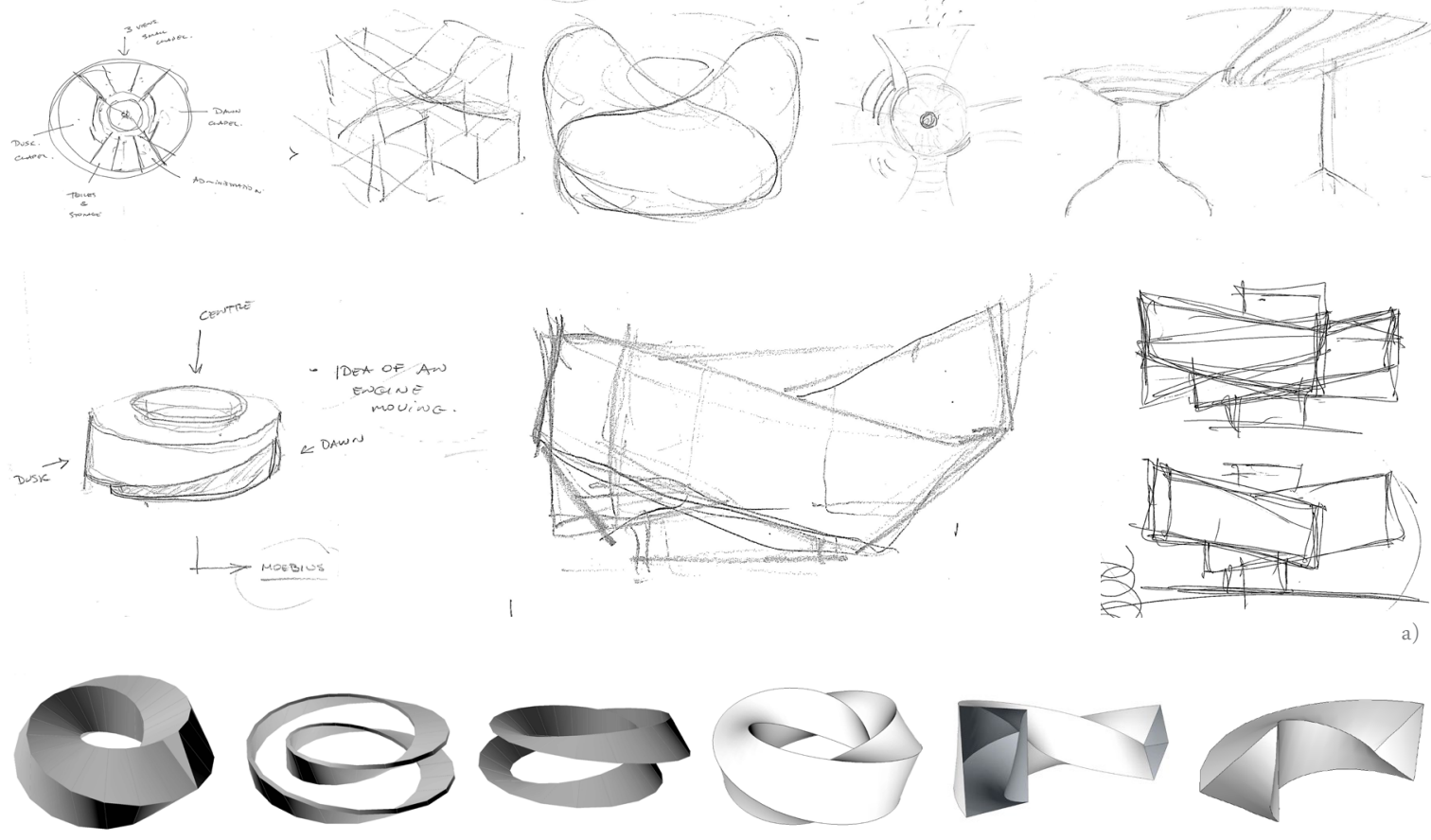

b)

Figure 69) Experiment Two - Exploring Möbius form through drawing (a) and digital experiments (b)

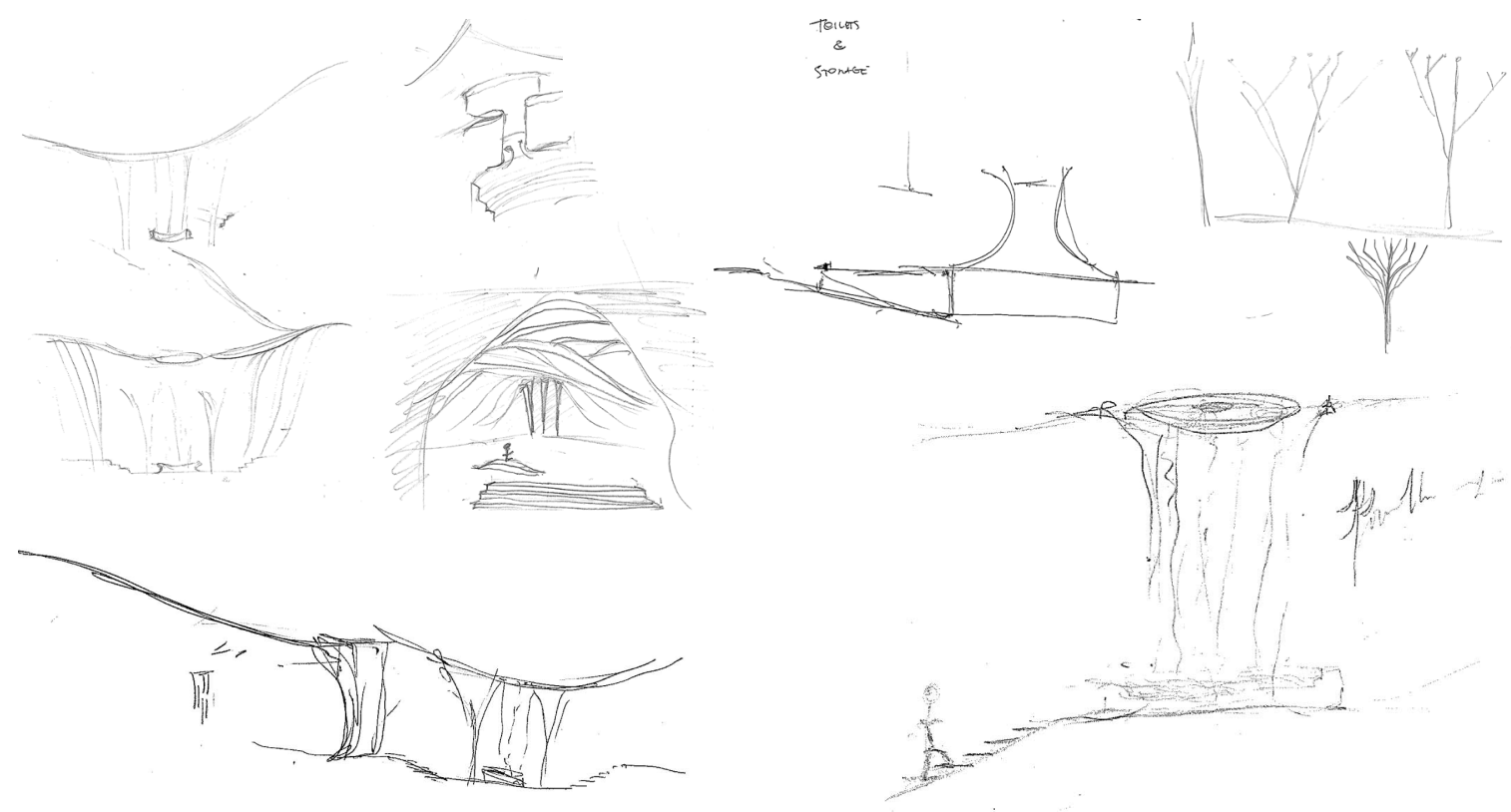

Figure 70) Experiment Two - focusing on central space with architectural features of columns 

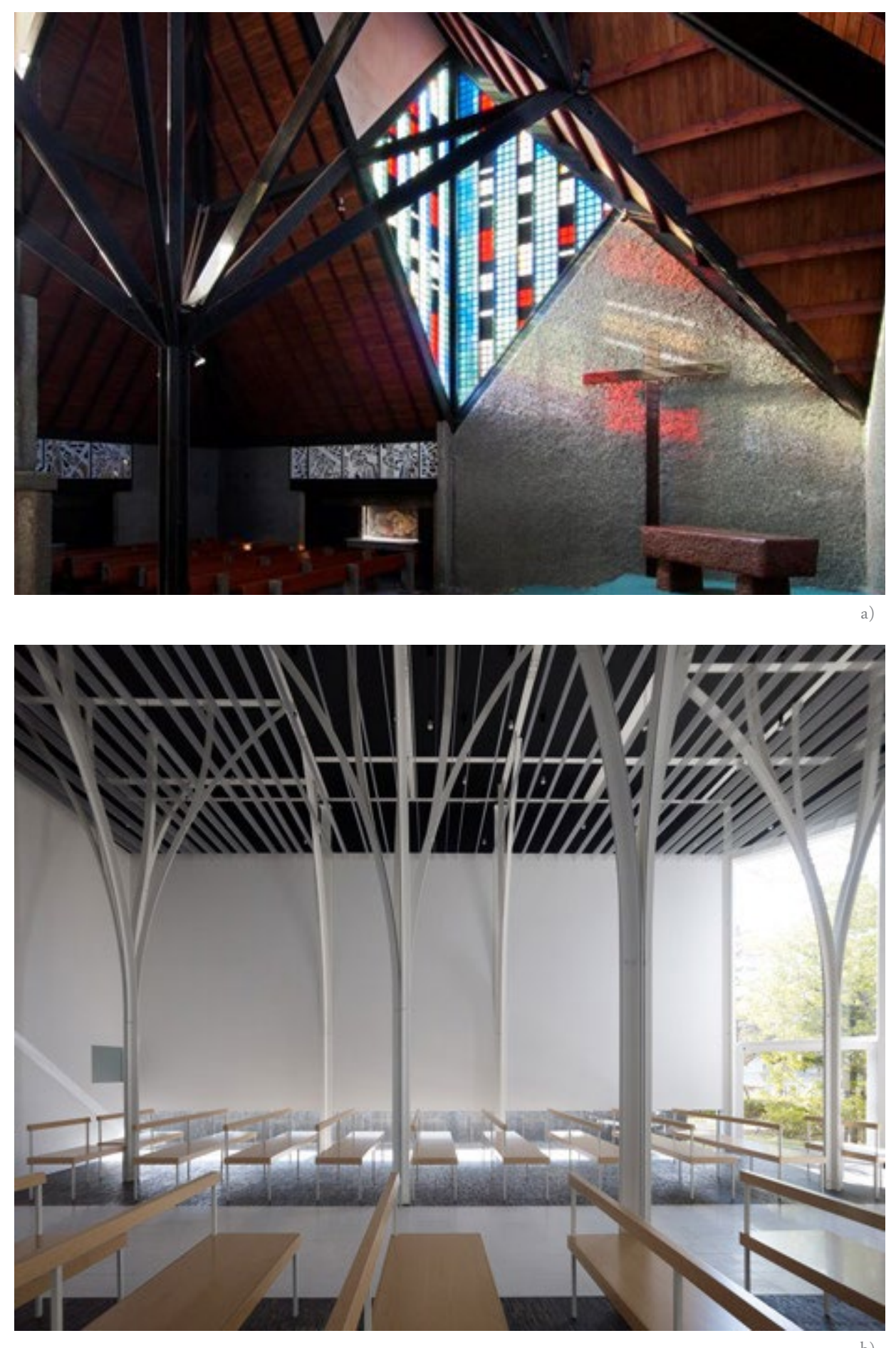

Figure 71) Result of Experiment One - Exterior view structure on site (a) and Interior view of potential dusk space (b) 

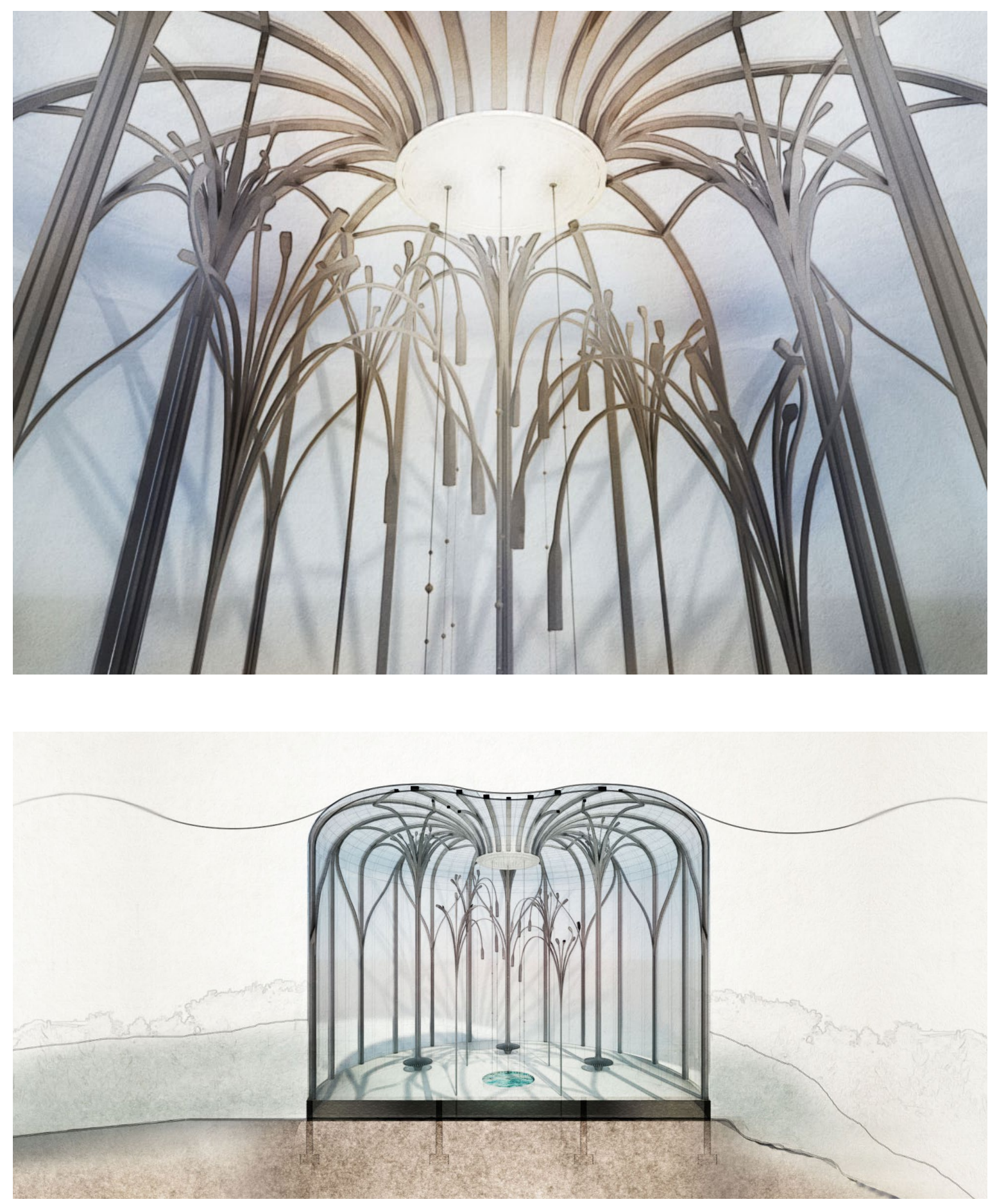

Figure 72) Result of Experiment Two - Interior view drawing focus to the sky and the centre (a). Interior section showing potential Central space (b) 
6.6 Revisiting theoretical research and site exploration

Both experiments One and Two plunged directly into the design phase without consideration of the early site investigations, or the literature review. At this point of the process I needed to revisit the theoretical framework and develop a design scheme which deploys symbolic composition and adopts the spatial conditions learnt in the literature and project reviews, while sensitively engaging with the site context.

6.6.1 Universal Symbol through architectural form Reflecting back to the theoretical framework of my research, the analysis reveals that the way in which sacred spaces express symbolism architecturally, enable the experience of the space to be holistically meaningful. From this stage, the design deployed my interpretation of the mandala symbol compromising of the circle, triangle and square. Reviewing Ando's Water Temple, Safdie's Yad Vashem Museum, and the classical Pantheon, was influential to this stage of the design. These case studies use symbolic means to compose architectural forms, which is what needs to be done for successfully attending to the design issues of this thesis.

6.6.2 Site Diagramming and Programmatic Schemes - Second stage

Revisiting the site and specifically analysing the topography and the existing forms and then applying a layer of the symbolic forms from the mandala helped to generate the reformed basic structure of the design and incorporate all the spaces in a coherent manner. The new series of site drawings and digital form manipulation show the spatial arrangement and planning of spaces.

(Fig. 73)
6.7 Redefining the design approach

The new approach involves using the methods of design learnt from the literature and the project reviews, with an added layer narrative design conveying universally accepted concepts of journey and pilgrimage through the intervention, as well as abstracting the mythical story of the Taniwha. This enabled the design to be specific to Wellington context, and embrace the multidiverse culture of the city. 

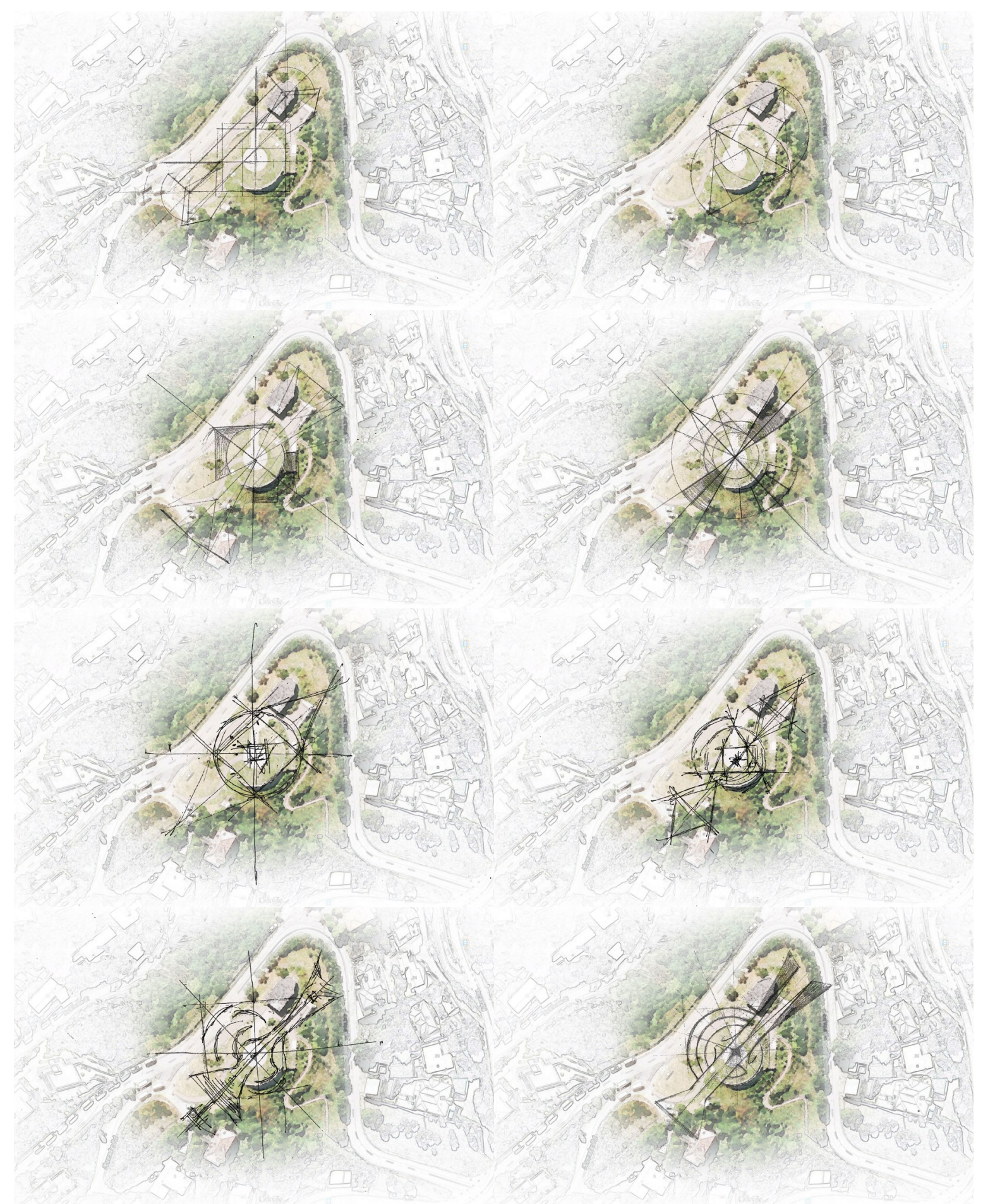

Figure 73) New site drawings in plan gradually exploring symbolic meaning and narrative to create a holistic intervention for the Sacred Site. Sketches show thinking process and design techniques learnt from the literature of Carl Jung and Thomas Barrie, as well as techniques analysed in case studies. 
CHAPTER SEVEN 


\section{DEVELOPING UNIVERSAL SANCTUM}

\subsection{Introduction}

The preliminary design stage experiments produced unsuccessful results but they were imperative to the process in filtering out all the ideas and potential solutions. The experiments resulted in designs which were monumental and objectively sculptural. The design development section will look at how the concepts of the previous experiments were developed in a spatial and experiential manner characteristic to the interior architecture discipline.

Criticism of the early experiments was predominantly of the lack of engagement with the essence of interior discipline. The new approach considered the concept of submersion into the earth and the integrated experience. The notion of journeying into the earth expresses a submersion of the conscious self into the unknown depths of the inner spiritual self. This gesture was experimented with spatially, so the architecture itself would bring visitors to this frame of mind rather than through readings or rituals. This also allowed me to focus on the space on an interior design level, articulating a spatial experience and detailing elements which would contribute to the whole intervention.

7.1 Holistic design sketching and modelling

This process entailed constantly alternating between sketching spaces in plan, section and perspective, and $3 \mathrm{~d}$ modelling. Fig. 74 shows the initial thinking process with all the aforementioned concepts in mind.

\subsection{Developing Narrative}

The narrative of the design tells a story through the way in which the spaces are sequenced. As noted by Barrie and Harries, this approach is common in sacred spaces as they often emulate a narrative through spatial arrangement. This an effective way for the architecture to express symbolism.

\subsubsection{Function and arrangement}

The initial function of spaces remained the same but the architectural intention was developed to be cohesive and each space was in the dialogue with the other. Allocating a specific space for meditation was eliminated in the developed design as areas within each space can provide for self reflection. These spaces were further developed by the key findings from my literature and case study research. (Fig. 75)

$$
\begin{aligned}
& \text { ARRIVAL - Entrance } \\
& \text { AXIS MUNDI - Centre } \\
& \text { Light of DAWN - East } \\
& \text { Light of DUSK - West } \\
& \text { LIBERATION - View }
\end{aligned}
$$

\subsubsection{Pilgrimage on site}

Since the concept of pilgrimage is important to the thesis, the design takes into consideration the path which will bring people to the site. The core of this thesis is that the design intends to be inclusive of the various religions and social backgrounds. In this way, the journey may start from any part of Wellington city and the arrival will be at the inclusive entrance of the Sanctum. The intervention in itself articulates a sense of pilgrimage as the space moves from the entrance to the centre where the design splits to three directions depending on which space one desires to experience or straight through to the Liberation space with a harbour view look-out. 

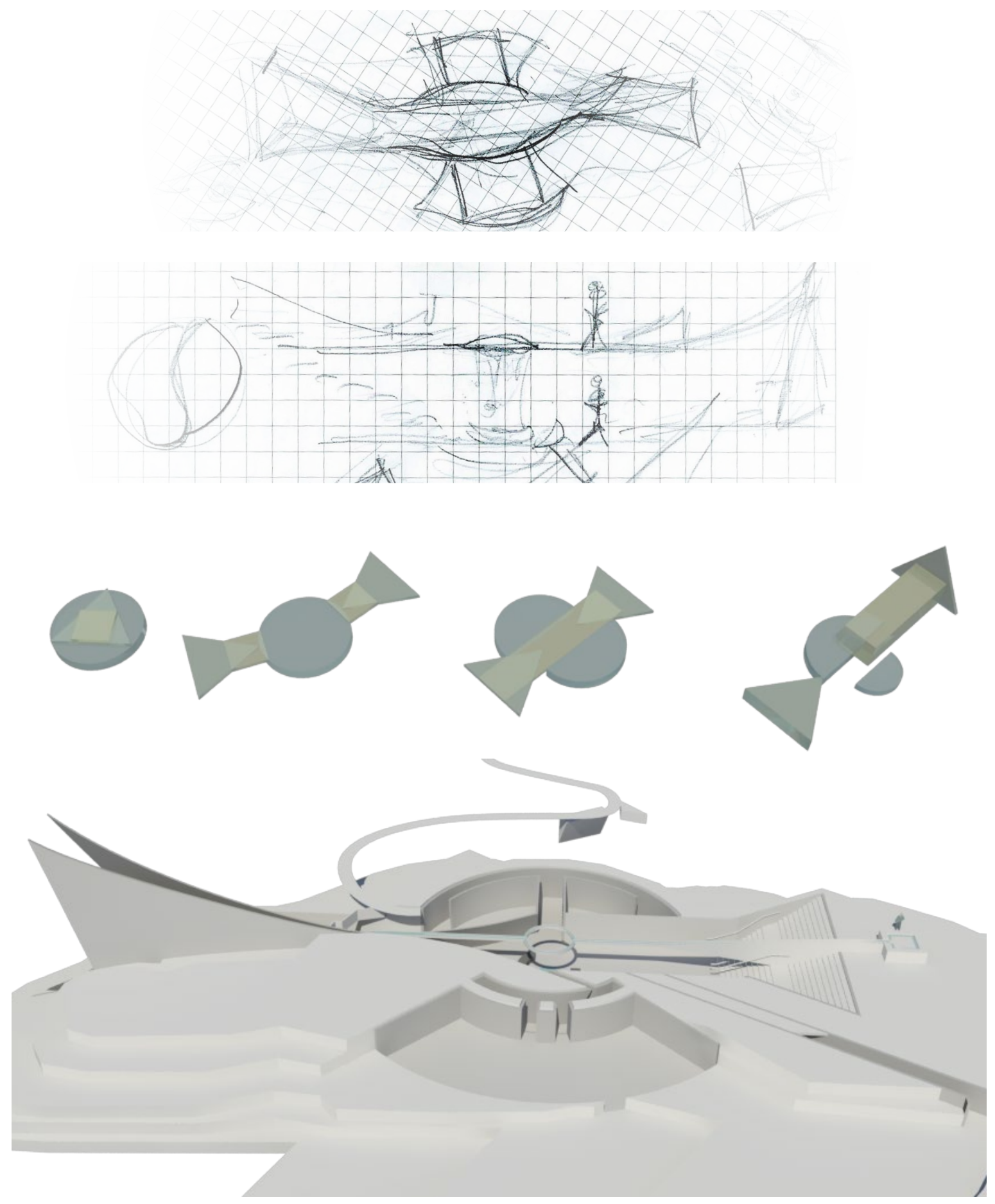

Figure 74) Sketches and digital modelling experiments which sparked the new approach to design. These employ concepts learn from the literature and case studies, as well as respond to specific site conditions of sun/wind and topography. 

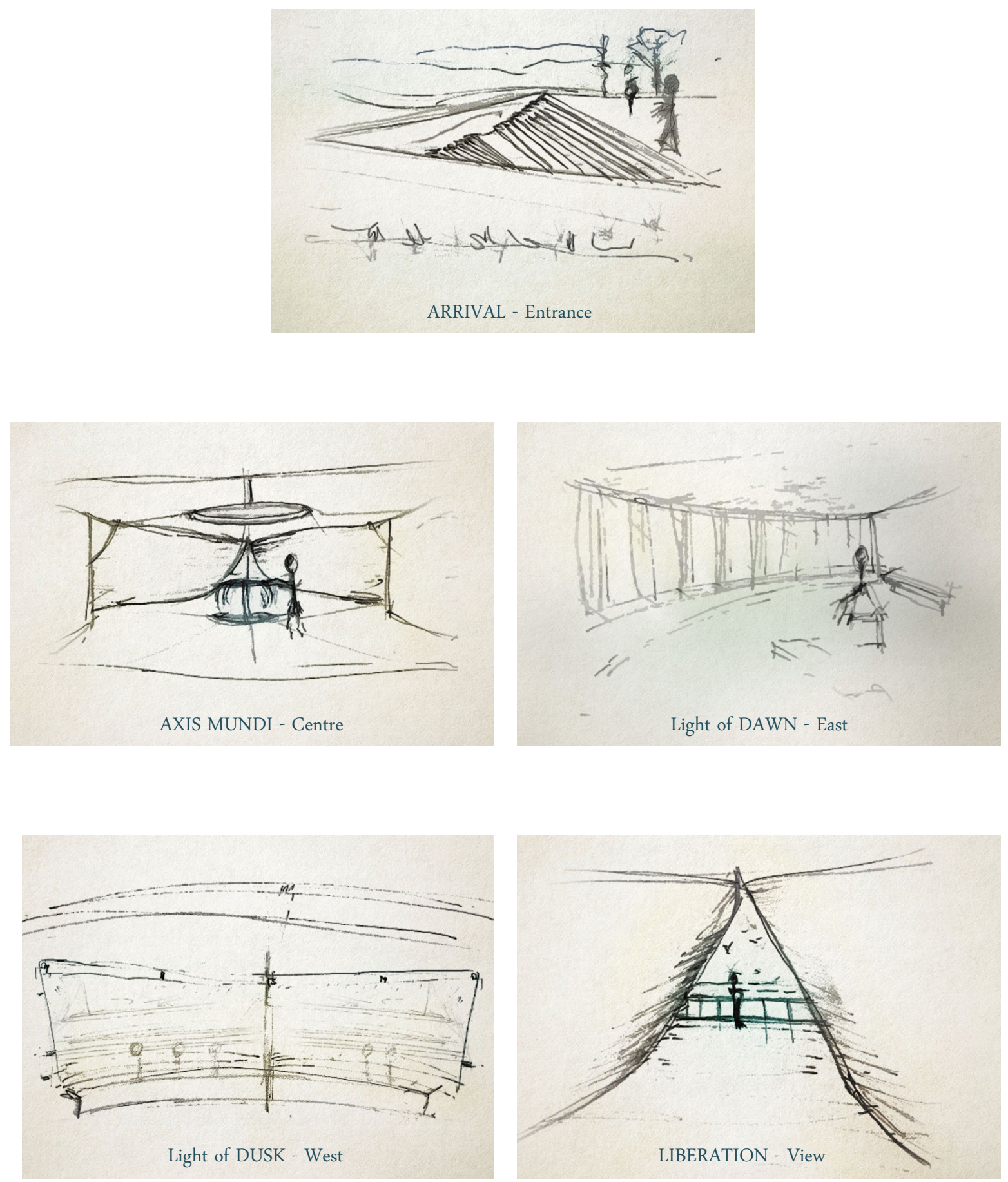

Figure 75) Sketching the final 5 spaces of Universal Sanctum to be developed. These spaces are planned as journey through the space but are not restricted to a particular path in the intervention, so visitors have flexibility to be in whichever space they wish be in. 


\subsubsection{Axial Path | Split Path}

Thomas Barrie writes about pilgrimage through the design of sacred spaces in that these typologies often have distinctly planned paths. There are two types of paths; Linear, which include axial, bifurcated or split, radiating, grid and concentric. Segmented paths include labyrinths and connected series. He explains that although not all sacred architecture fits specifically into these categories, it is important to note that all sacred spaces use spatial planning devices to convey a sense of journey. . (Fig. 76)

"A clearly articulated entry, a sequence of increasingly sacred spaces through the path, a clear making of path surface and edge, a consistent ordering of structure and materials and a symbolic story expressed by the path and place"1

The Sanctum is planned according to the axial path where the design follows a symmetrical layout. Prominent examples of architecture which uses the axial path are the Japanese Shinto shrines, where the atmosphere turns to a pantheistic view of nature, and Egyptian architecture of the late kingdom where the temples were an expression of 'Gods Paradise' on earth. These forms of architecture emphasise symmetrical planning, specific orientation, and a sense of progression towards the sacred.

The axial path manifests in the Sanctum as the entrance steps descend into the immersed path leading people to the centre. From this point the spaces are counter-balanced symmetrically but in itself are asymmetrical in scale and proportion. Highlighting the cardinal directions of the site is quite important to the design in terms of orientation and weather condition sunlight and channelling the wind). Consequently the spaces are aligned North, East and West. The progression to the sacred in the Sanctum is accentuated by the use of lighting and detailing of the water.

The design also exhibits qualities of the Split Path. This path is similar to the axial path in a symmetric sense however the path either diverges into separate paths or several paths converge into a single path. The Sanctum can be seen as splitting from the centre point to the three directions and back up to the entrance. Creating this journey through the architectural paths gives the space a universally reflective sacred atmosphere.

7.3 Conveying myth through design

Referencing the story of Wellington harbour's Taniwha, the design subtly aims to covey the sense of liberation as Whataia felt when he reincarnated into the bird. (App. 3) The swooping architectural notion of the aperture leading to the look-out depicts this sense of freedom and connection to the natural environment. The body of the spiritual taniwha can be abstractly seen in the intervention. The anthropomorphic architecture is sunken into the earth as Whataitai. Although these anthropomorphic and symbolic ideas are not explicitly referenced through iconography in the Sanctum, they provide meaning to the way in which the design of these spaces was considered.
Barrie, T. Spiritual Path ...

$79-111$ 

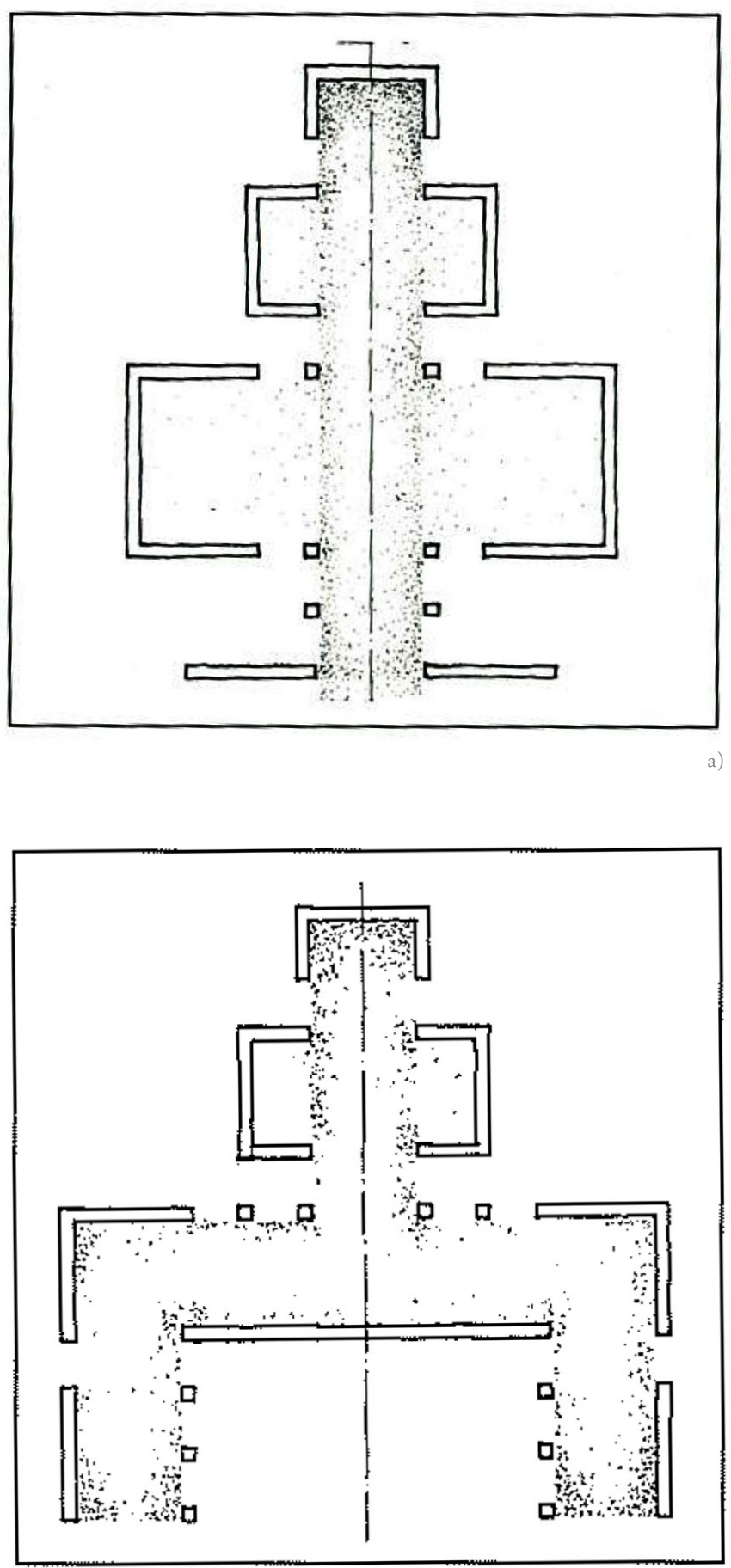

Figure 75) Spatial path diagram described and depicted by Barrie in Spiritual path, Sacred place: a) Axial Path and b) Split Path 
7.4.1 Final Design Result - The INTERIOR

\section{ENTRANCE: ARRIVAL}

The pilgrimage for visitors starts from their current time and place. This could be during the day or night, and from any part of the city. Whenever the need to spiritually re-energise arises, individuals or small groups can visit the Sanctum.

Arrival sees an all-encompassing wide entrance which spatially narrows as one descends to the underground spaces. Before entering the interior, visitors see the entrance steps split by the water trail. This is an important element to the design poetically and sustainably. Referencing case studies of Scarpa and Kahn, the use of water immediately takes visitors to a consciousness of sacred cleansing and mindfulness. Sustainably, the water feature has the ability to recycle rainwater and re-generate it for the central water fountain in the underground interior.

Reflecting the square design of the water trail, the developed landscape features a resting spot with seating for those who wish to experience the space above before entering the interior.

Entry to the Sanctum can also be accessed from the existing track leading to the site. This entrance leads visitors straight into Dawn space. (shown in plan views)

\section{CENTRE: AXIS MUNDI}

After stepping down into the interior, visitors can walk to the central space where the Earth meets the sky. Axis Mundi, the centre of the entire design, is where visitors can visually and or physically connect to water. The roundness of the water feature mimics the circular skylight directly above it. This skylight bring daylight into the interior and can also be considered as the oculus of my design, giving visitors views of the heavens above. All the other spaces of the Sanctum axis off from the central space, therefore it can be considered the pivotal point.

EAST and WEST: DAWN and DUSK

These spaces are aligned to existing forms of the site, in south-east and north-west directions. These spaces propose small groups to gather for ceremonies or for individuals seeking internal contemplation. Dawn allows daylight light to delicately enter the space through thin slits. These screens can close at night with sliding shutters.

Dusk reveals light to the interior from behind translucent stone. The space is split into two areas by thin slits similar to the screens designed for Dawn. This enables various groups of people to use the space at the same time, facilitating a sense of privacy which is often required of these spaces. (App. 4)

Although titled East and West, it is important to note these spaces are not specific to certain religions, nor do they represent a particular religious group. The design of Dawn and Dusk was developed pragmatically according to the site conditions, and poetically to symbolise symmetry of spaces balanced from Axis Mundi.

\section{VIEWS: LIBERATION}

Liberation, architecturally emerges from the underground. This space is an aperture offering views of the harbour hence connecting visitors to the surrounding nature. Before walking to the edge of this space, the water trail from above ground cascades down the centre of the triangular form, and travels down the slope towards the views. This movement of water draws people to a transcendental focus. 
7.4.2 Final Design Result - The SANCTUM in it is Entirety

The common spatial conditions as analysed in the literature and case studies are articulated in the developed design;

- Symbolism is expressed spatially through the form deploying the Universal Mandala of the circle, triangle and square.

- The element of water in the intervention can be seen as universally symbolising sacred qualities but the trail itself travels along a path which can express its own pilgrimage.

- Artificial light throughout the intervention highlights how visitors can journey through the space. The use of cove lighting between the walls and floors connects the spaces together.

- The materiality of the interior is kept neutral in accordance with the surrounding environment. Variations of concrete and stone are used to articulate the various features in the design.

- The underground spaces are proportioned humbly to the human scale, however, Liberation architecturally stretches upwards symbolically reaching the heavens. 


\section{EXTERIOR PLAN VIEW}

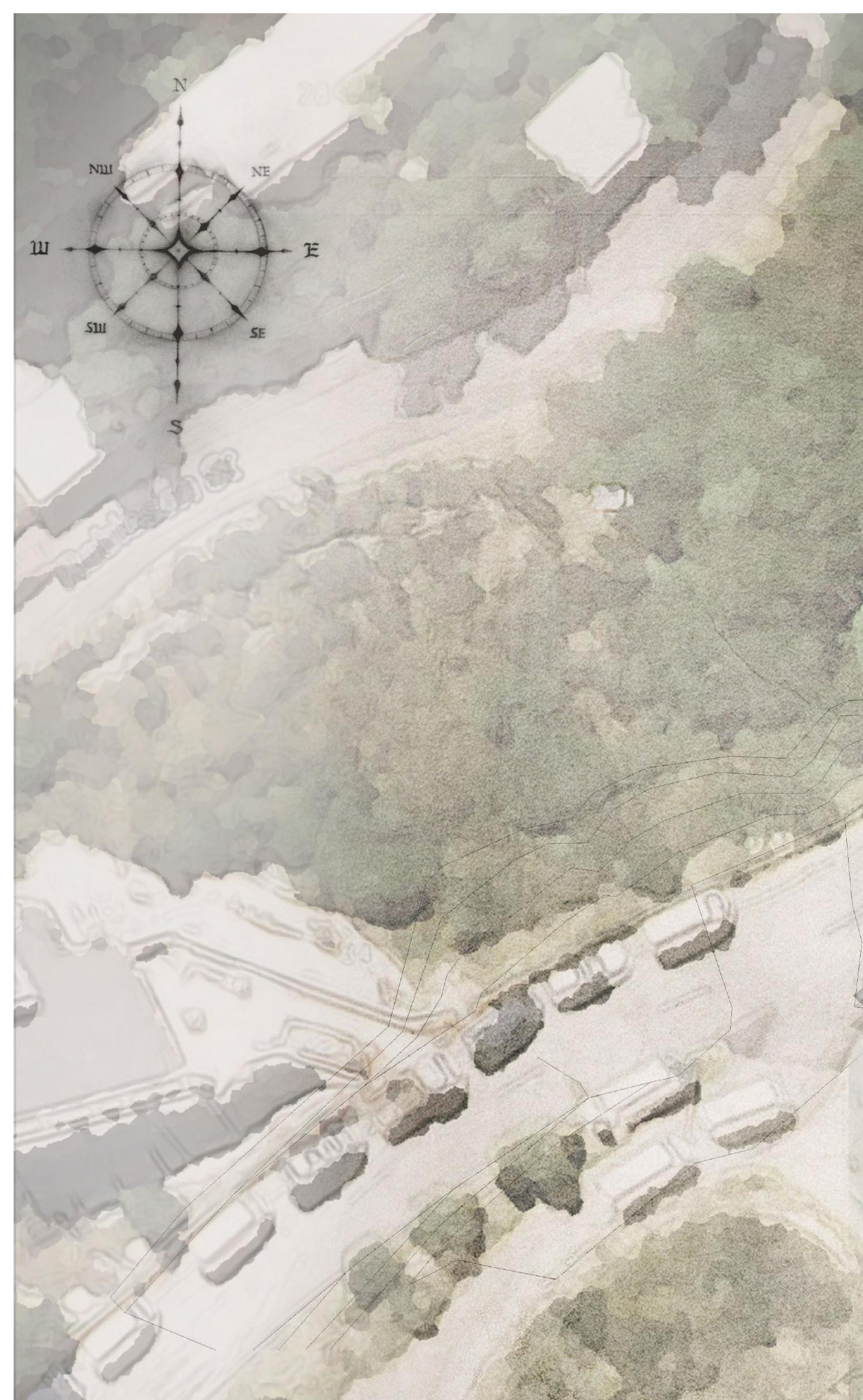




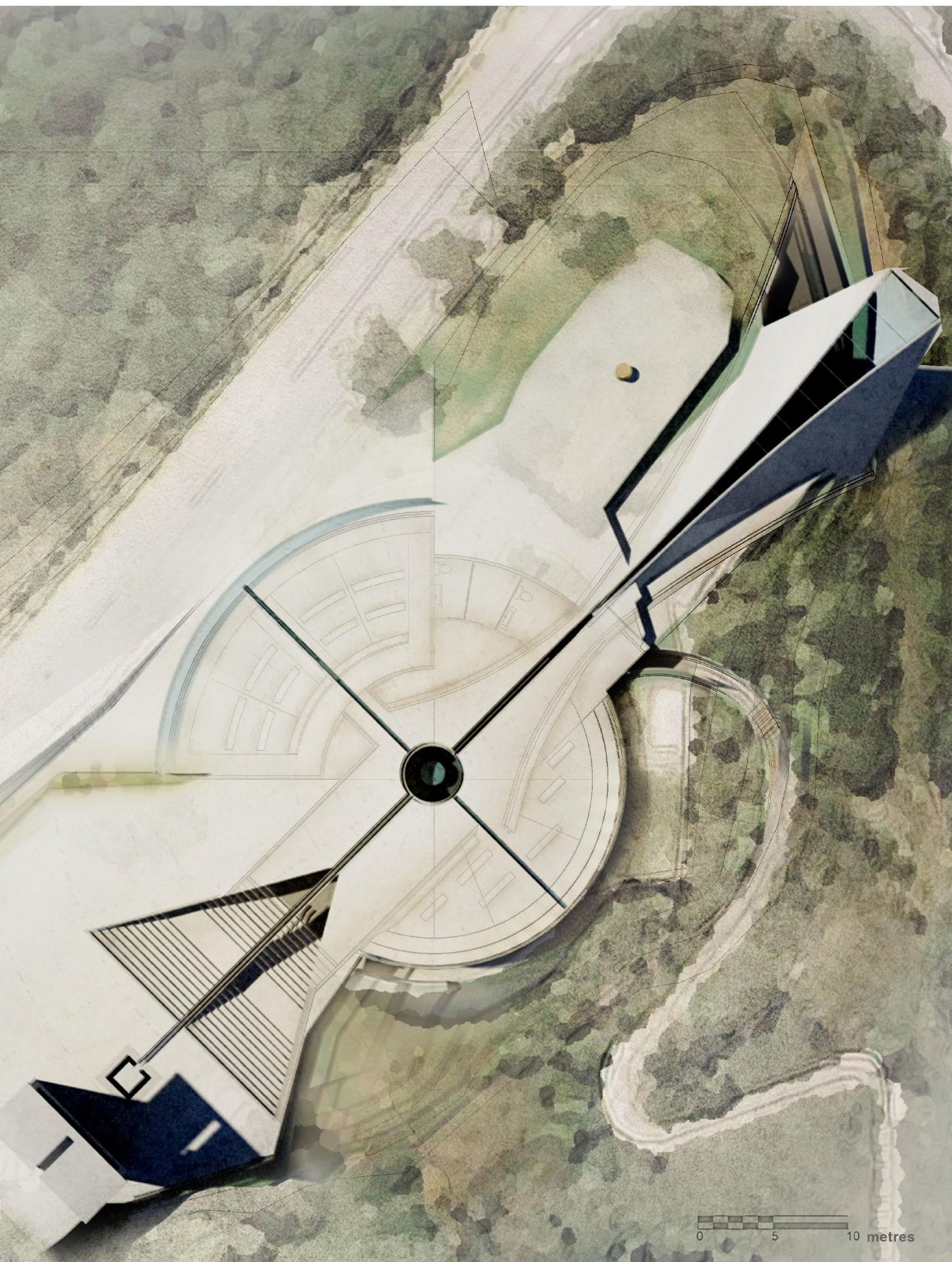




\section{INTERIOR PLAN VIEW}

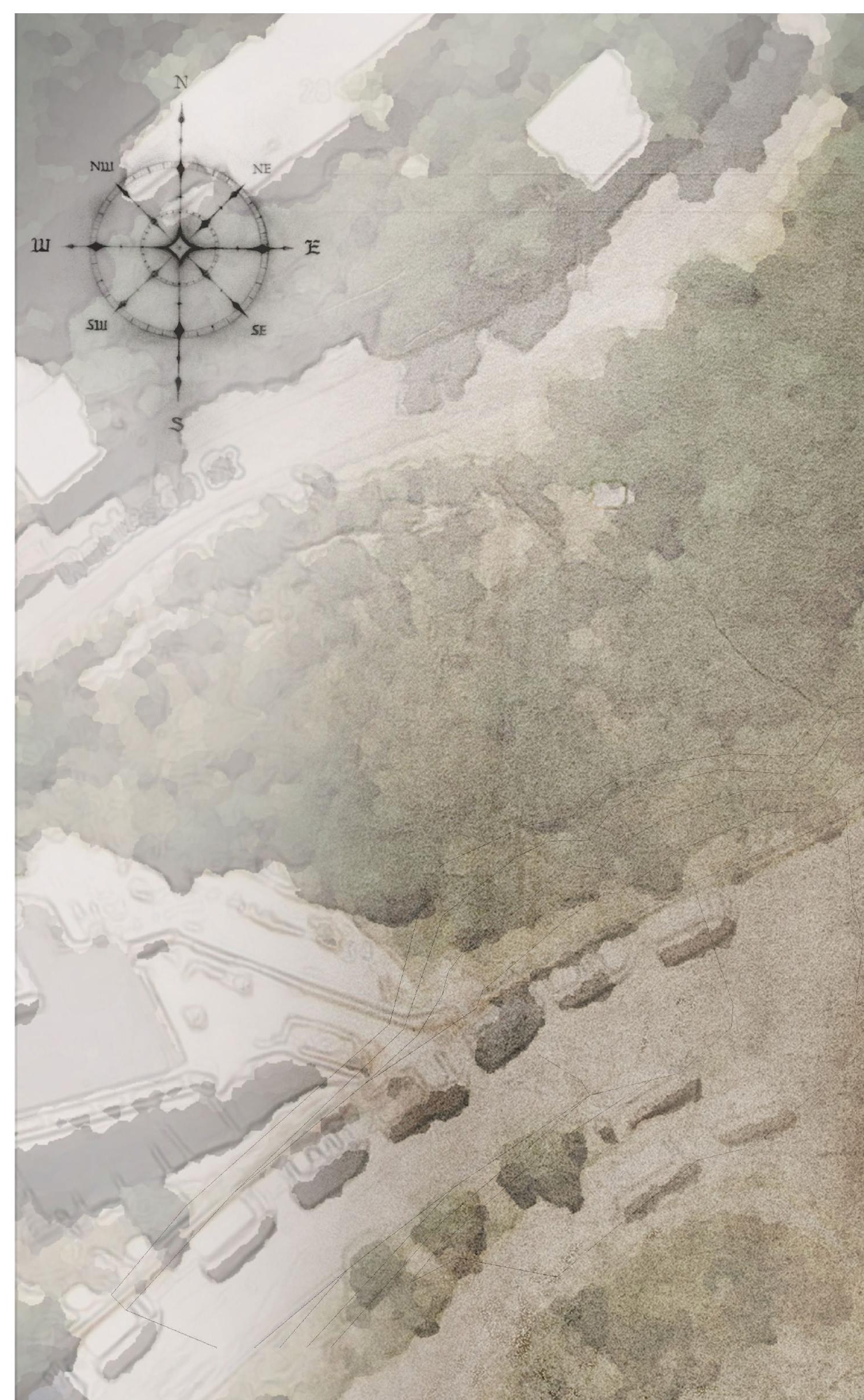




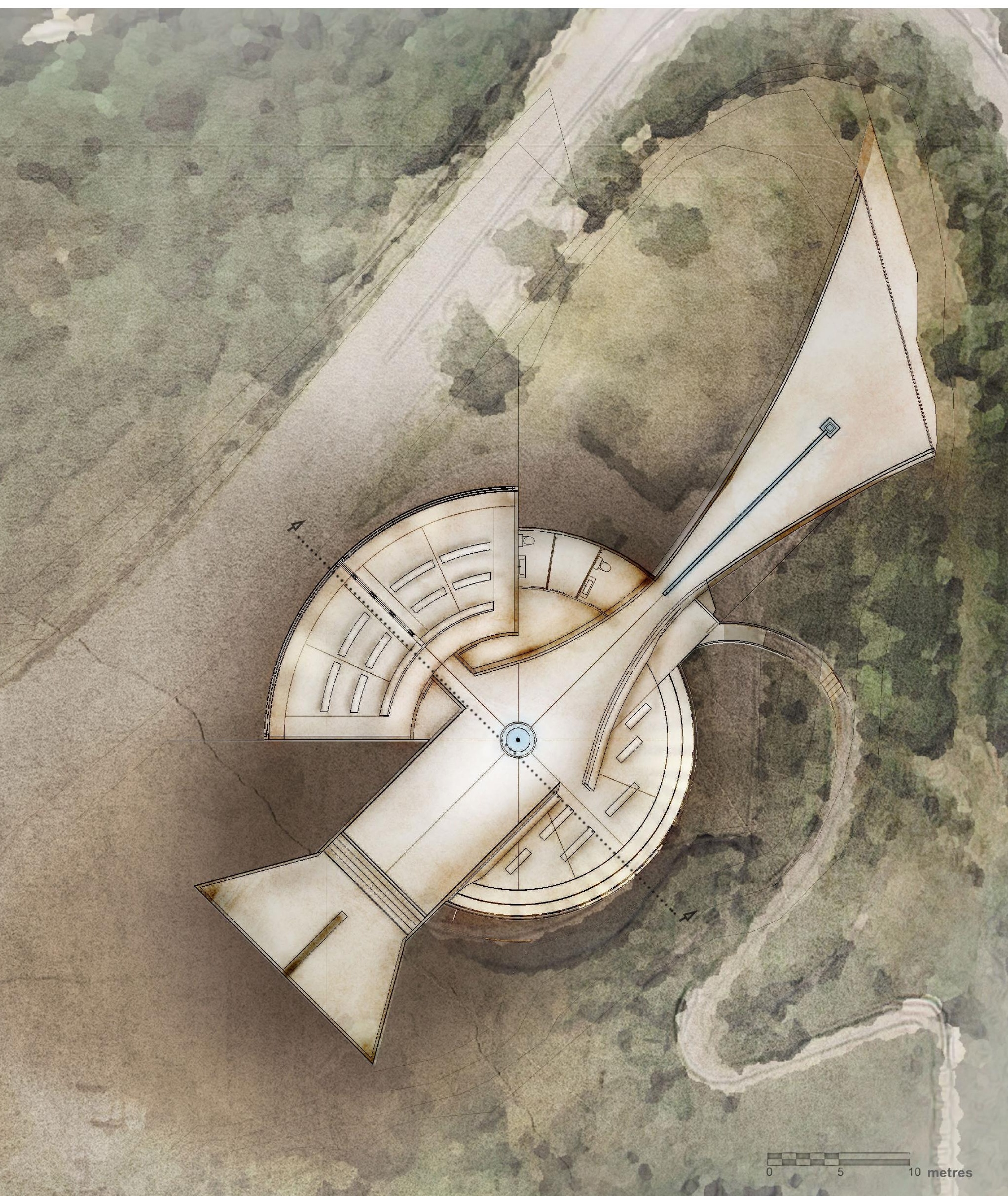




\section{SECTION VIEW}
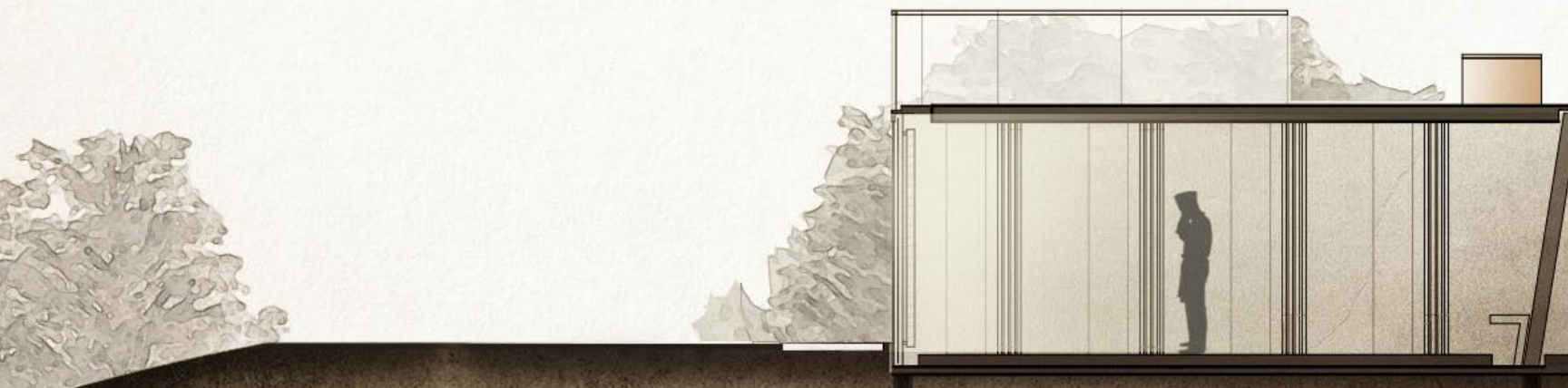


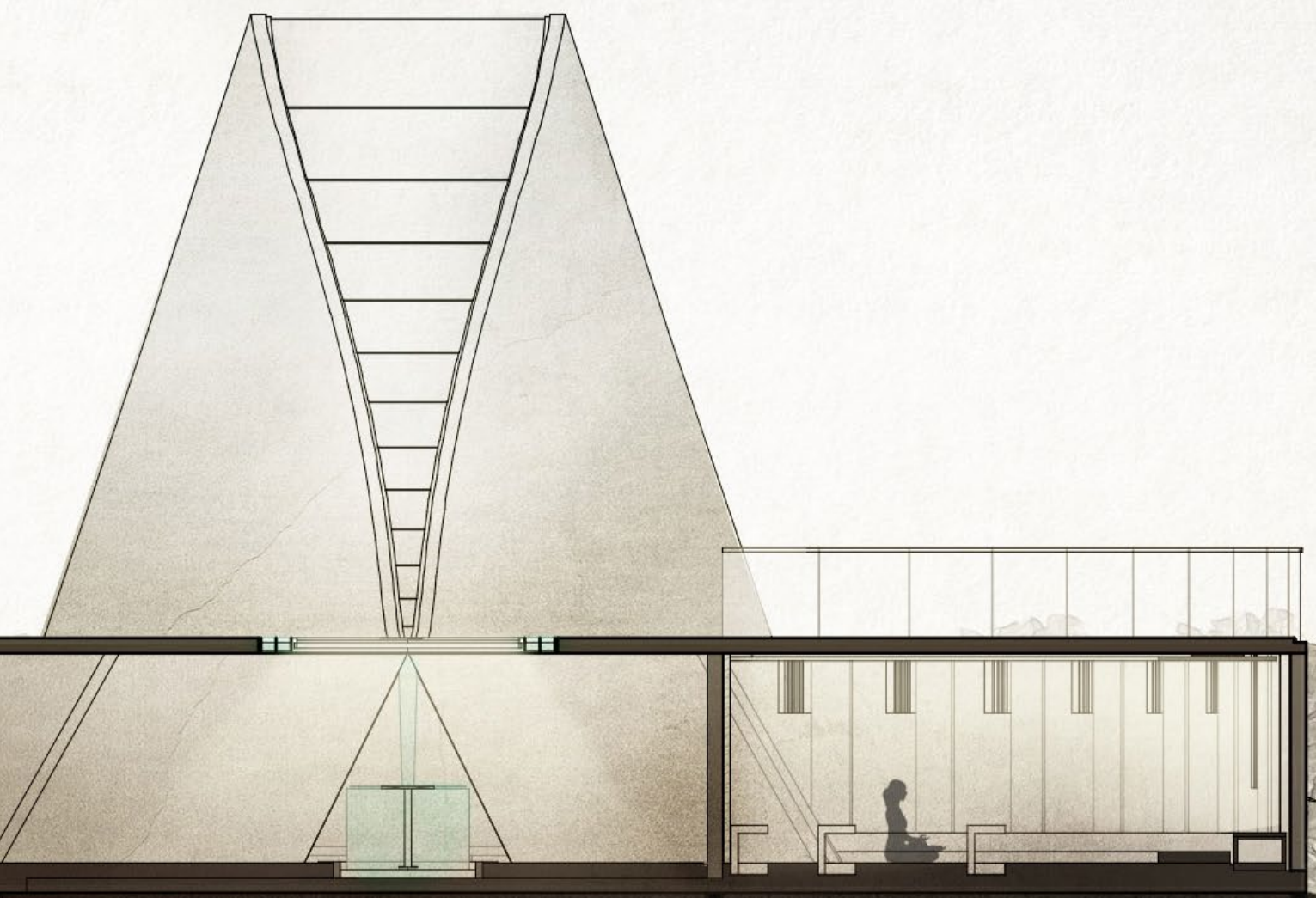




\section{STREET VIEW - the Sanctum in its entirety}

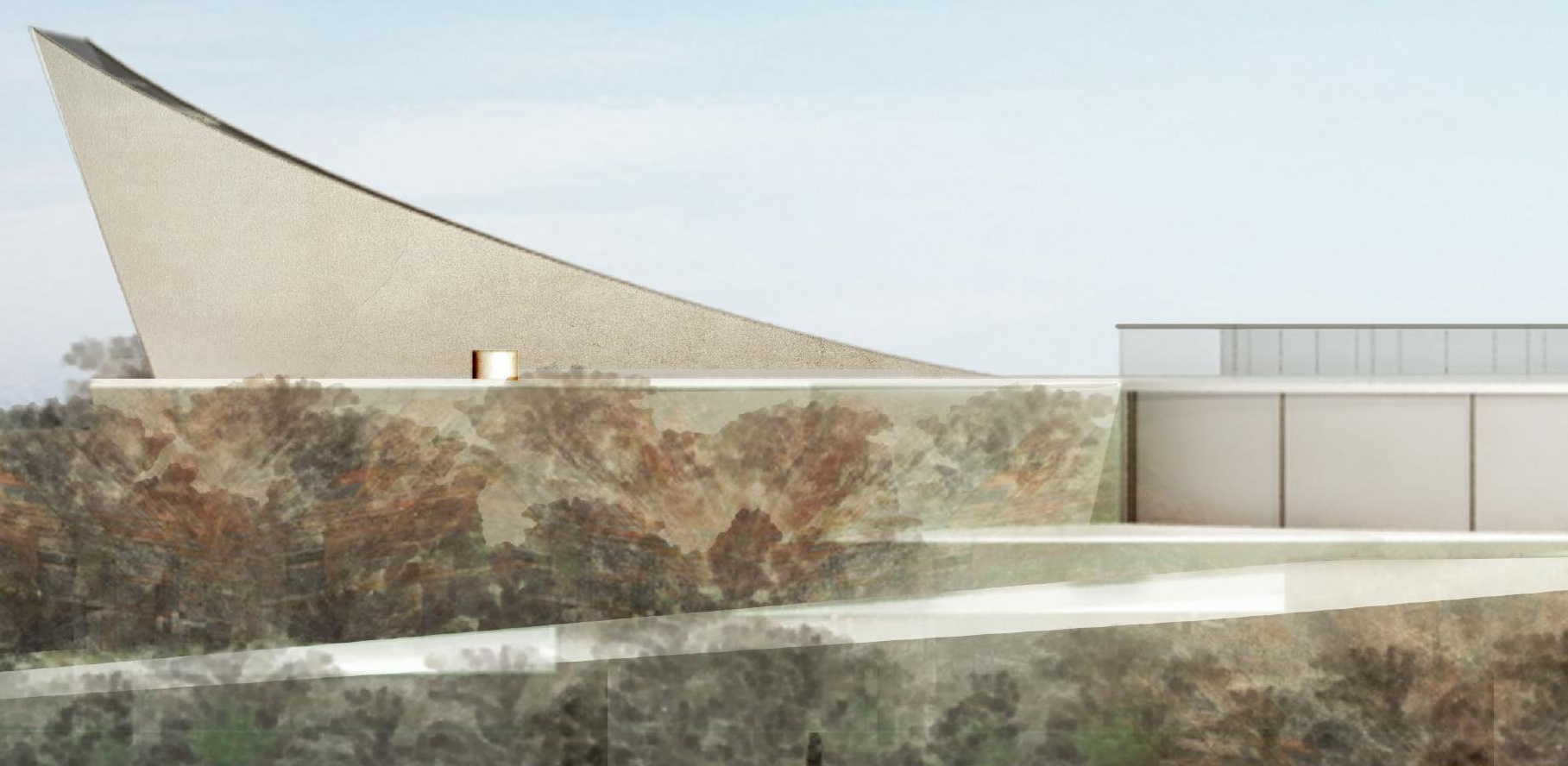




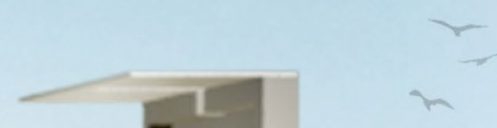




\section{ARRIVAL - the landscape}

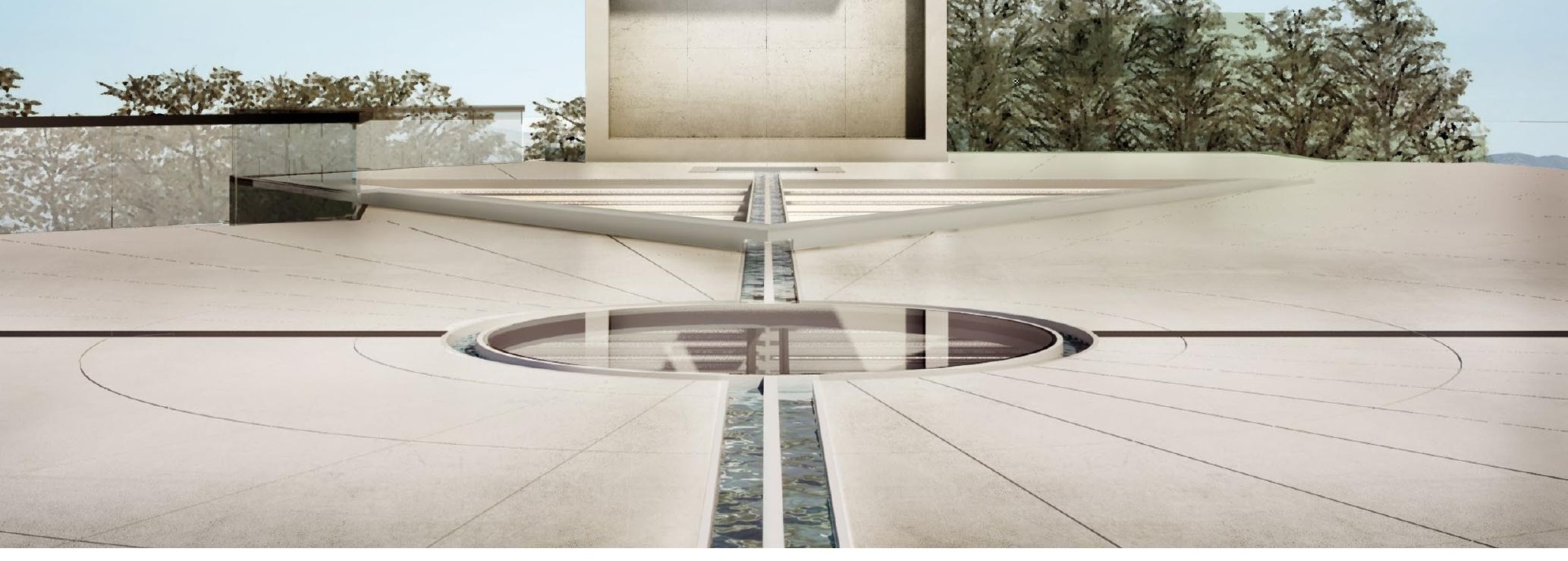




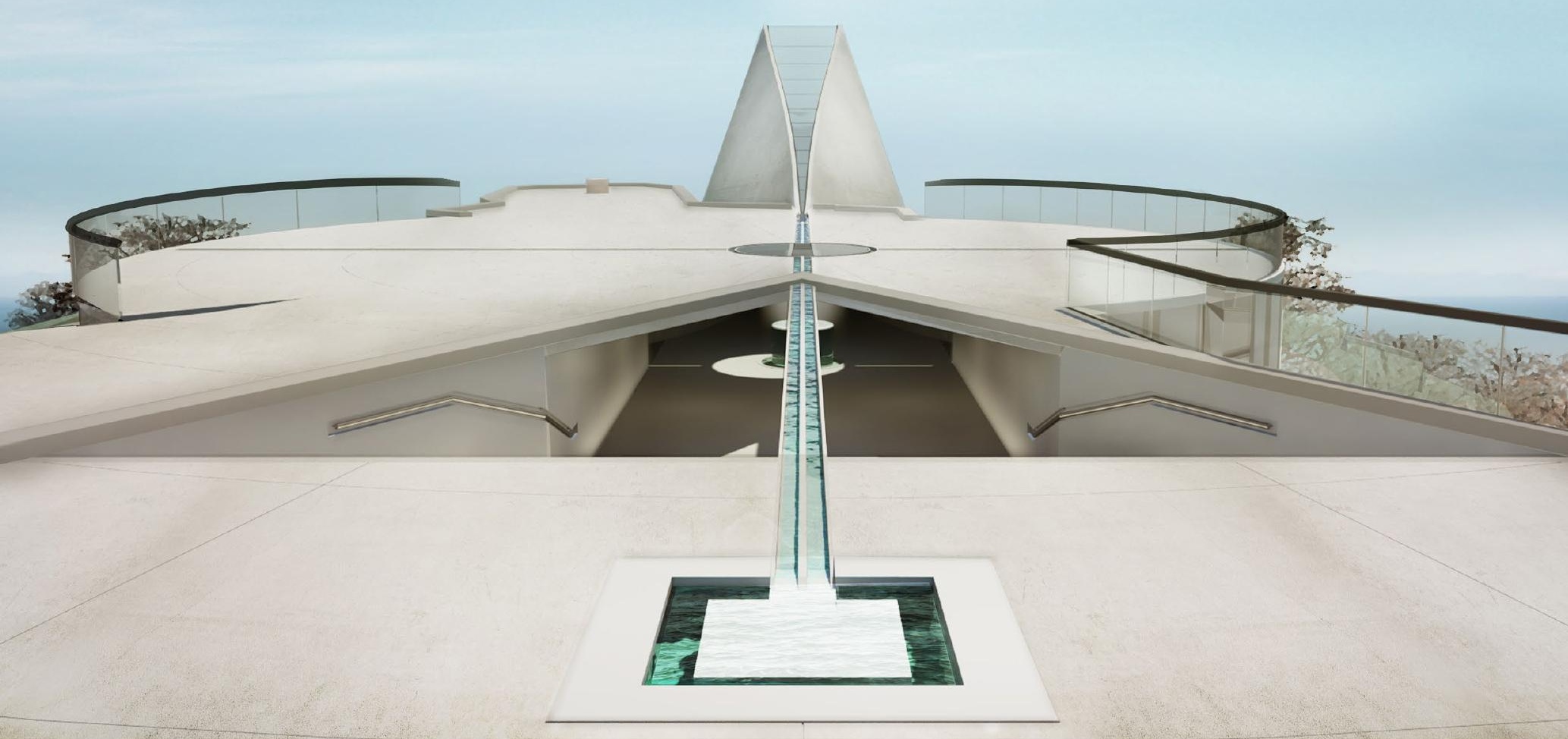


ARRIVAL - the descent 

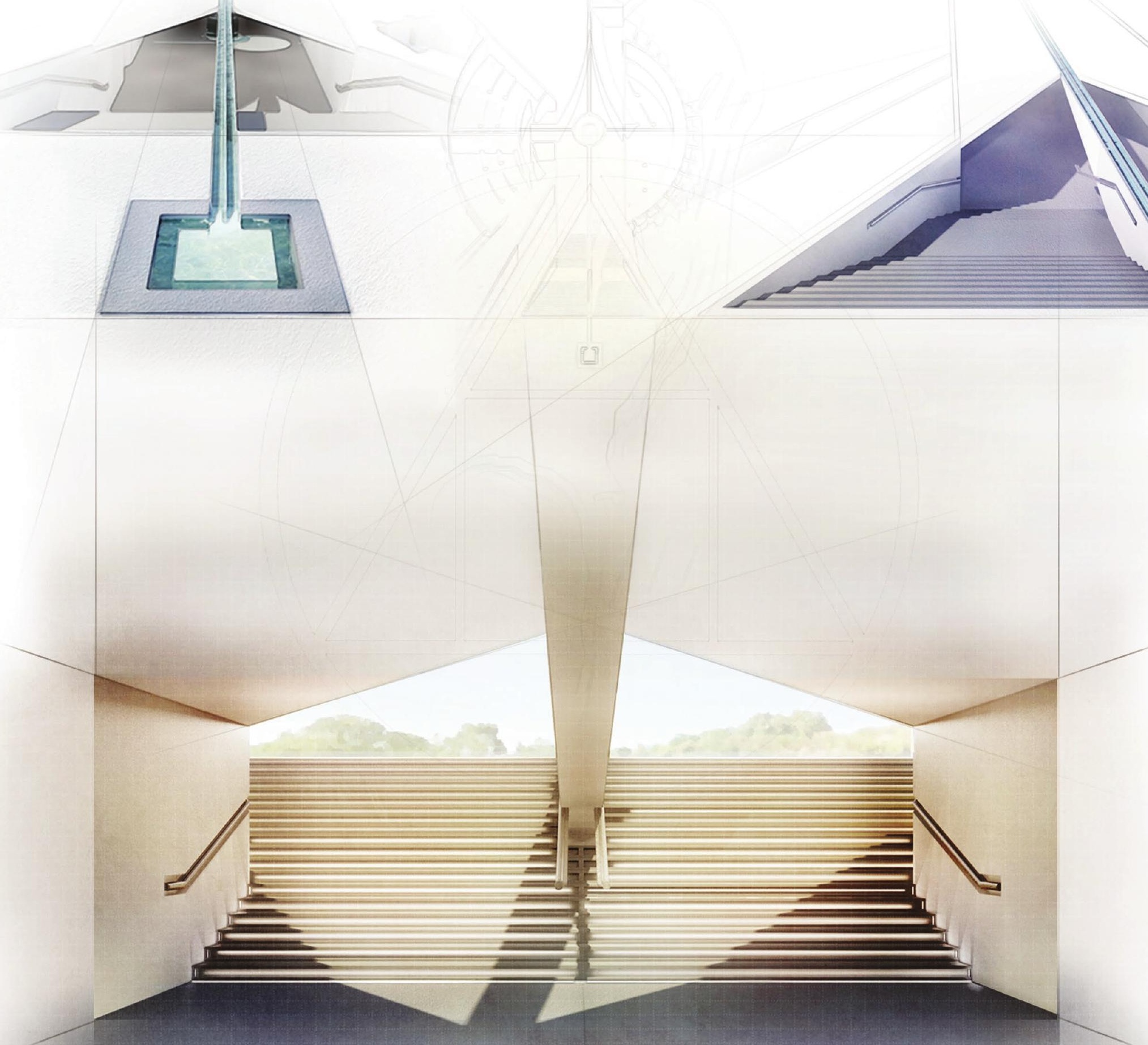
AXIS MUNDI - earth meets sky 


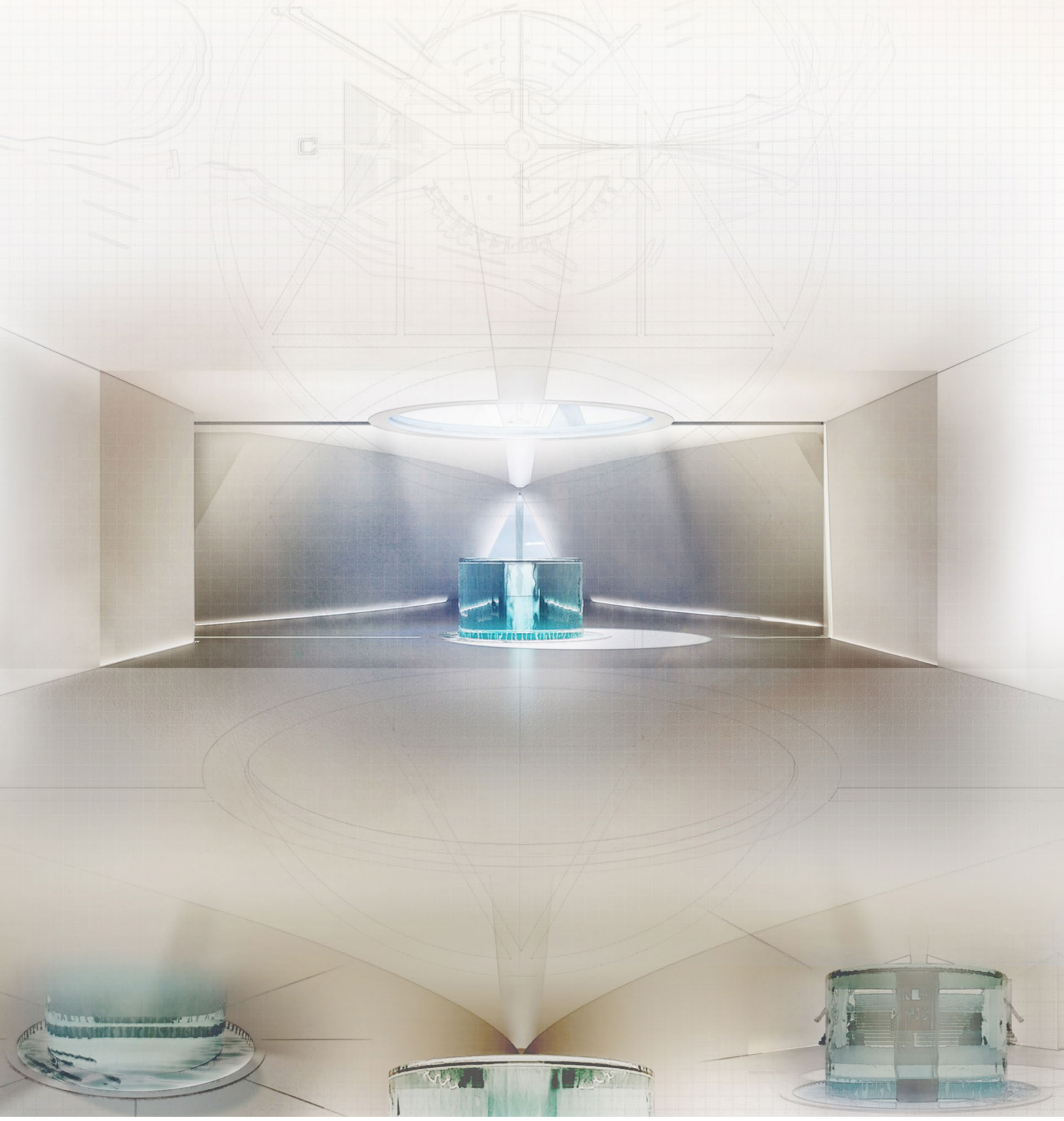


DAWN - light from the east 
(5)

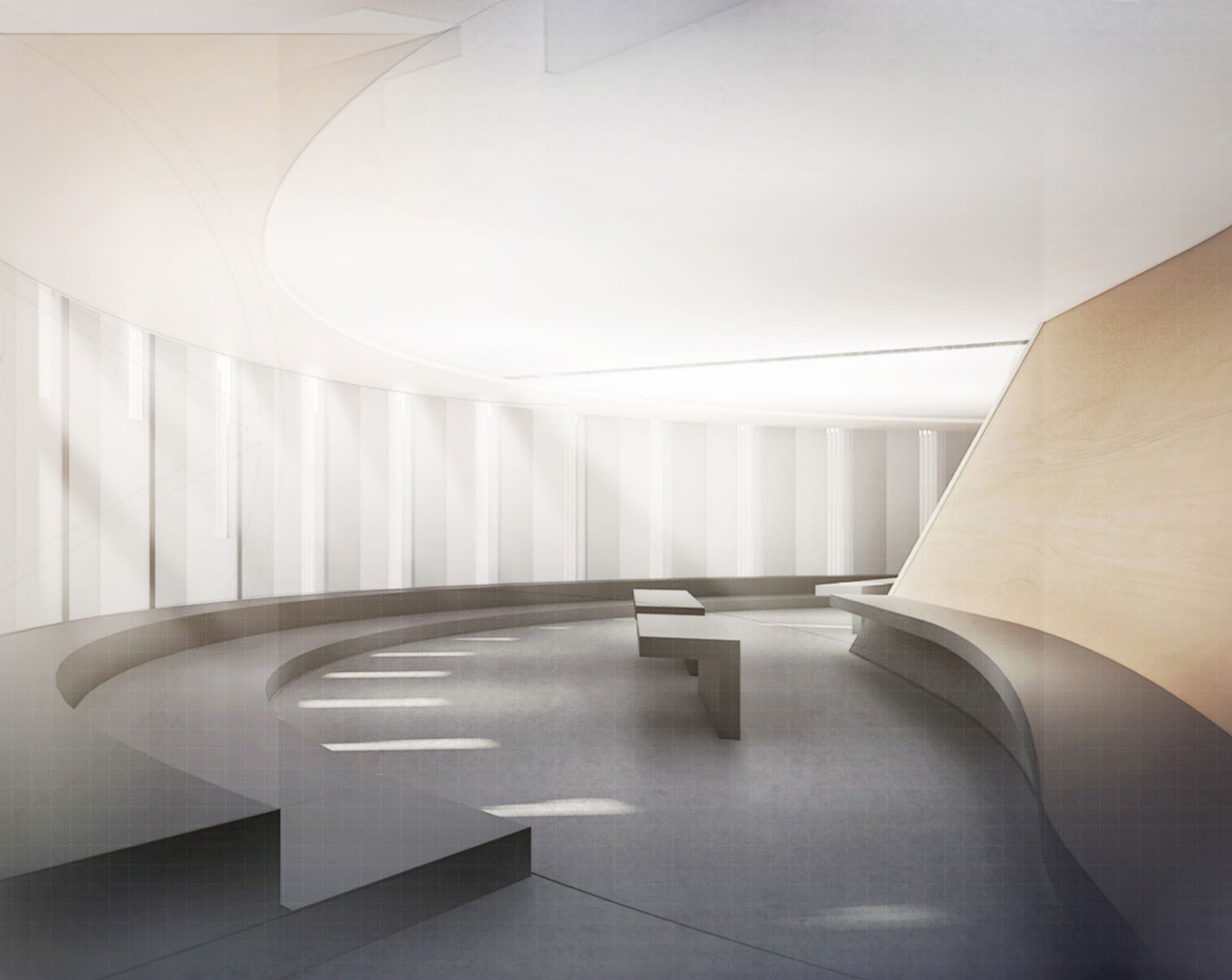




\section{DUSK - light from the west}




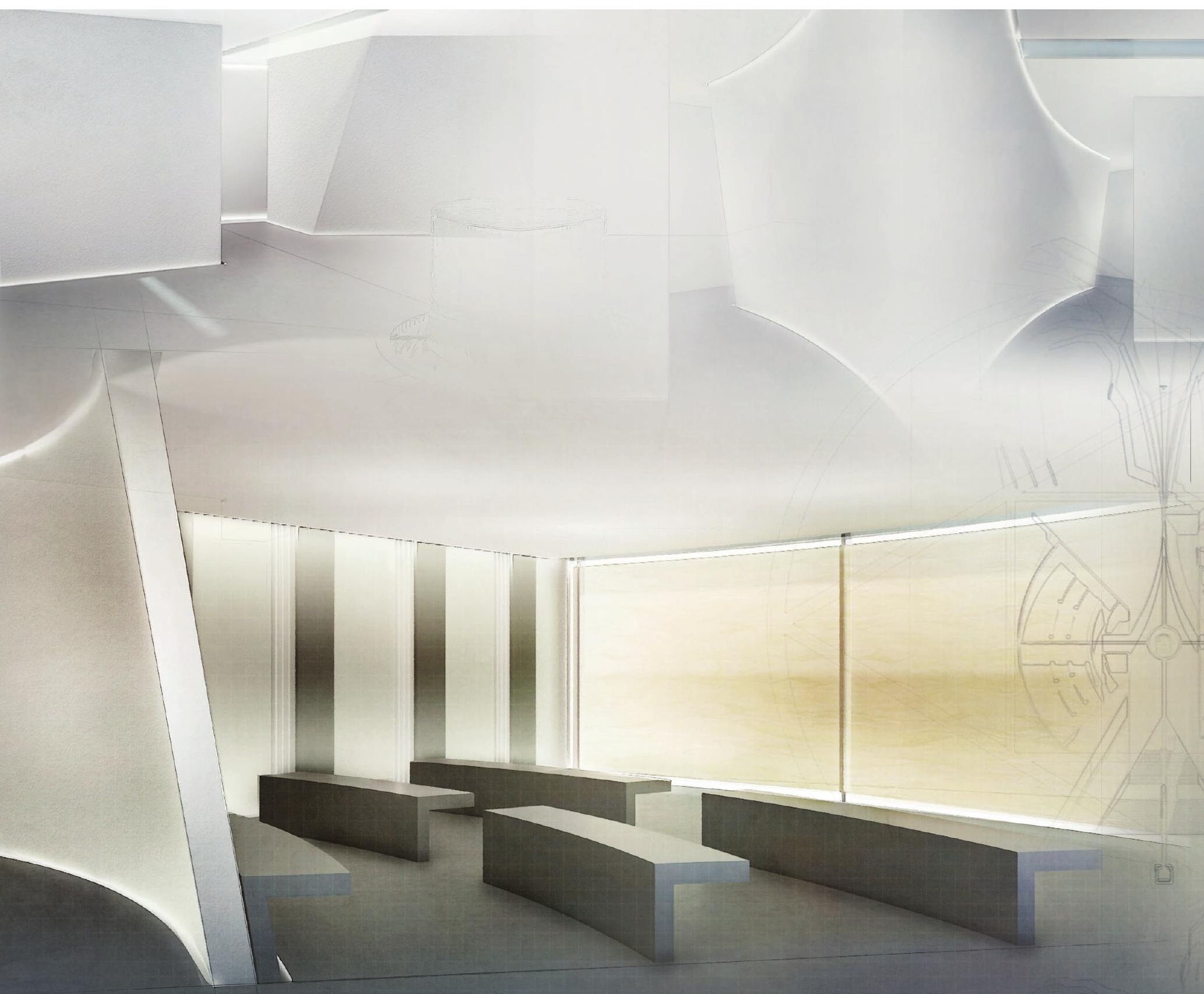




\section{LIBERATION - becoming one with nature}




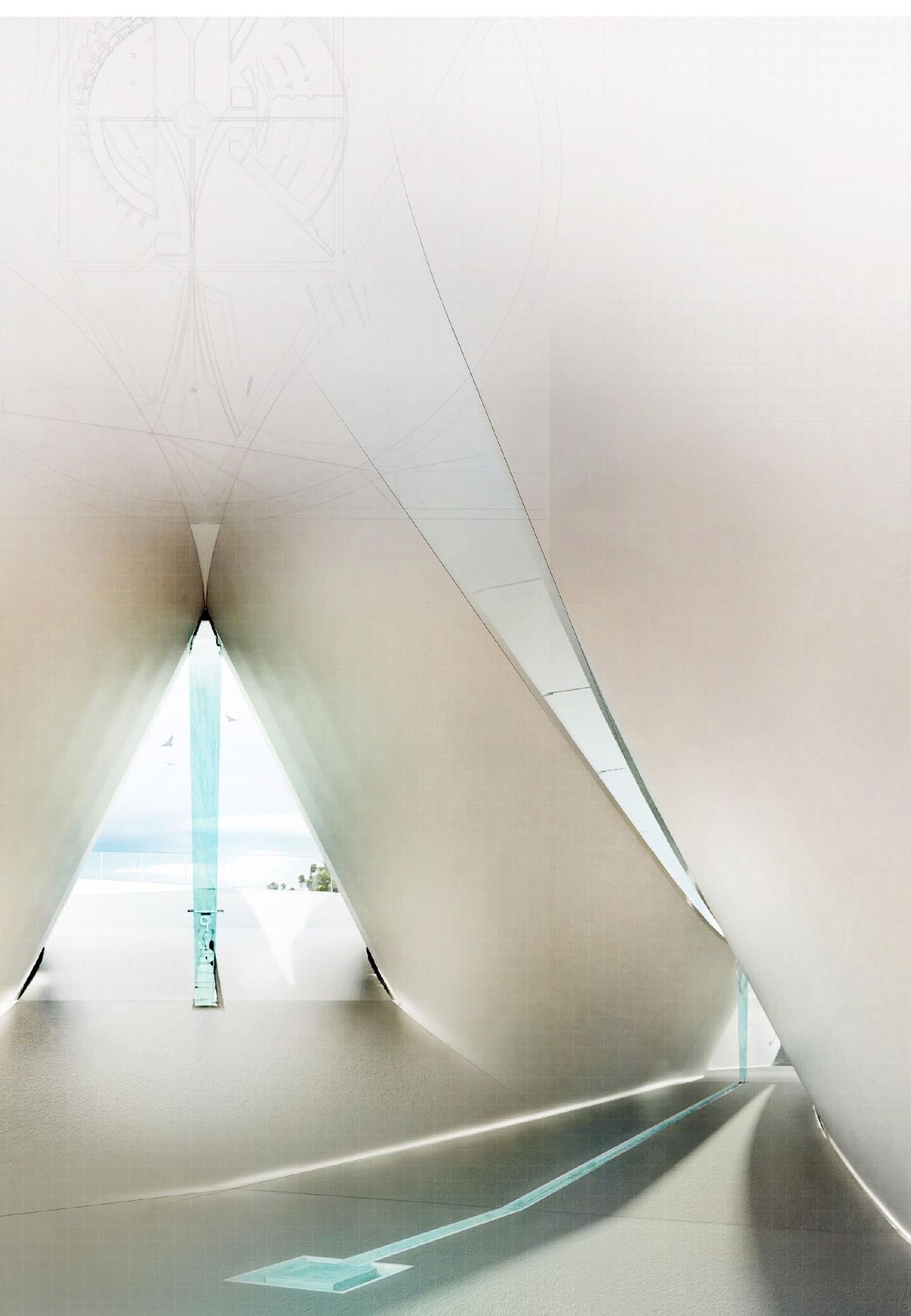




\section{DETAILING the SANCTUM}

Seating in Dusk

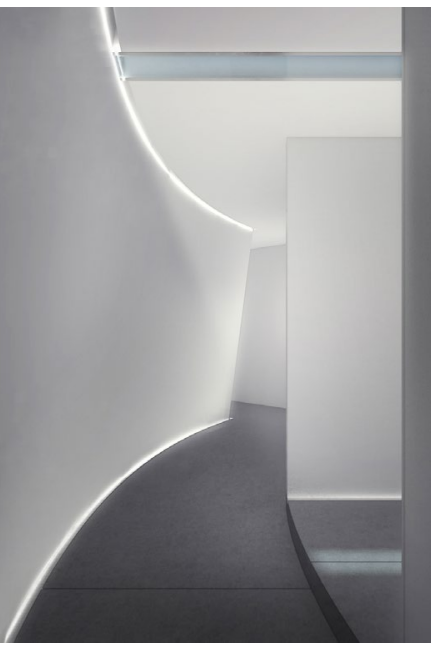

Passage towards Dusk

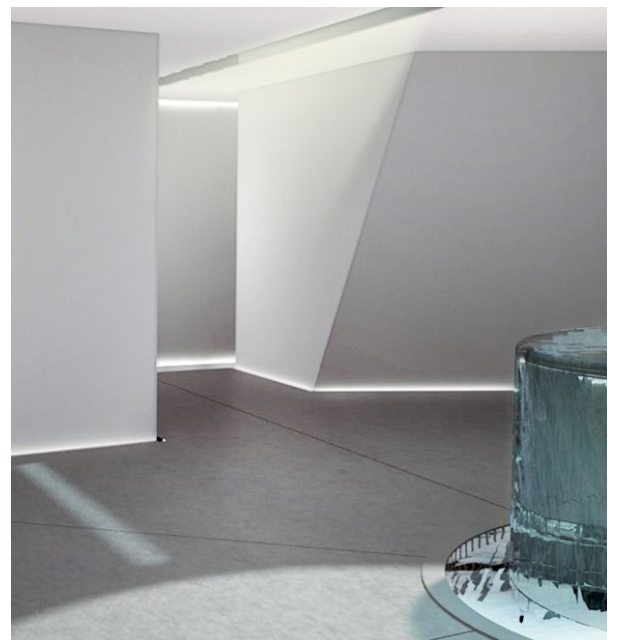

Entrance to Dusk

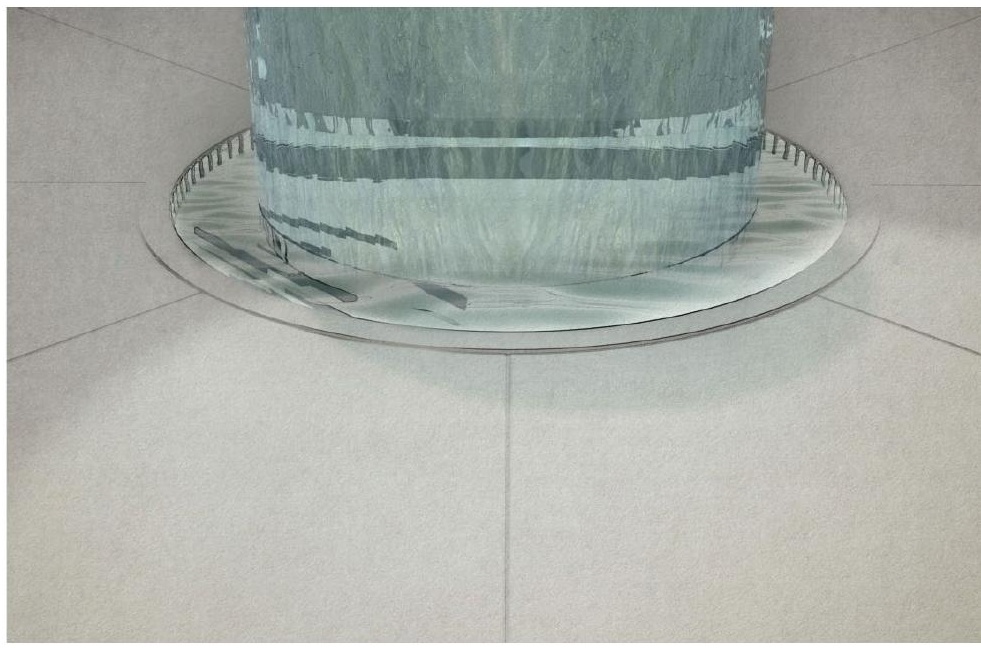

Central Water of Cleansing 


\subsection{Critical Reflections}

The design of Universal Sanctum has developed into a tangible and realisable space which employs specific spatial qualities relevant to sacred architecture. Integrating the various programmatic elements set out in the preliminary design stage was initially problematic for me. Nevertheless, the developed intervention successfully articulates these spaces as whole, from the major spatial elements through to the details of the spaces.

The Sanctum sits well in its surrounding context, however to further develop the design, a more convincing connection to New Zealand architecture needs to be explored. Although the Sanctum features notions of narrative design abstracted from the Taniwha legend, an experimentation of native New Zealand materials would have enhanced the design.

As a response to the aims and objectives of my thesis, the design process has resulted in a space which depicts commonly recognised qualities of sacred architecture. The Sanctum expresses qualities of light, water and symbolic form which allow visitors to transcend the physical realm making the intervention a mediator between people and the divine. The design also embodies the element of pilgrimage which is an important theme of many spaces and is commonly practiced and revered amongst the particular religions studied in my thesis.

The issue with this typology is that since religion itself is such a personal entity, the perception of sacred space will vary between different people according to their level of spirituality.

The space programmatically caters for diversity but individually it is difficult for me to determine if the Sanctum will be considered 'sacred' by all.
Referring to the theoretical framework, 'sacred' is dependent on its connectivity to site and context, and the way people place value upon it.

The developed design responds sensitively to the site submerging into the topography of Mount Victoria and leaving an outline of the Centennial memorial as well as keeping the Bronze Orientation Table. Unfortunately it is difficult to test if people would place value on my Sanctum as I would need to possibly conduct a survey of some sort or present my project to the people of Wellington and evaluate how they perceive it.

Nevertheless, I believe that not all people immediately connect to newly designed spaces, but as they start to use the space, they make connections to it and eventually respond to it. The Sanctum is a humble offering to the people of cosmopolitan Wellington, giving them a space for spiritual upliftment and realisation, which was the initial intention for the design of my thesis. 
CHAPTER EIGHT 


\section{CONCLUSION \& CRITICAL REFLECTIONS}

8.0 Why expressing the Sacred through design is important

The issue of this topic as outlined in the introduction is that awareness of the 'sacred' is diminishing with the advancement of modern sciences and technology. People have become absorbed in the material world and so the balance between the physical and the spiritual must be restored. As investigated in the various chapters of my thesis, design can offer an aesthetical and meaningful expression which people can respond to. Architecture can be experienced as a mediator between people and their innate yearning. The development of my thesis reflects on the need for a physical manifestation in order to journey inwards. The result of my investigation proves that the experience of a tangible space is important as it provides the first step to spiritual elevation.

\subsection{Conclusions from the Investigation}

Through my research I found that all people, religious or not, are in search for something more fulfilling than their temporal possessions. I discovered that architecture has the ability to provide a spiritual experience which transcends the physical world through the use of specific qualities. These qualities have power to express the incomprehensible nature of the 'sacred' and present in a way which can be understood spatially.

Through the investigation of Wellington site context, I realised that an intervention which responds to the city's spiritual atmosphere is beneficial. My research aspires to attend to the lack of contemporary spaces and aims to be easily be accessible to anyone during anytime.

Through the exploration of design, I learnt that for Universal Sanctum to be a convincingly sacred space for anyone, regardless of religious background, I needed to step away from scrutinizing specific religions. Referencing commonly acknowledged concepts of pilgrimage, water and connections to nature and the cosmos was more helpful to the design process.

\subsection{Constraints of the research}

As highlighted in the scope of research and my Organogram, the intention for my research was to conduct surveys with particular religious groups in Wellington city. The objective was to find out specific rules I would need to follow in order to attend to the specific requirements of their spaces. (App. 5)

Contacting these places and arranging initial meetings proved to be difficult. The leaders and administrators of the organisations were not helpful nor prompt in responding to my various emails and phone calls.

After many attempts, I made the decision to disregard the survey and do my own general research. I then realised that this was a positive outcome. The result from the surveys may have led to the development of a design which amalgamates various different styles of architecture, aiming to please the different religious groups and their requirements. Employing general qualities of sacred architecture was more useful to the design process and helped to produce a holistic response to the research question.

\subsection{Development of this research}

If this research were to continue beyond the scope defined at the beginning of the thesis, I would explore methods of creating a 'model' approach to bringing the 'sacred' to a city through interior architecture. This would involve establishing specific rules which could be followed as a process. 
Alternatively I would have investigated how sacred qualities of design can be implemented into the everyday secular spaces which we inhabit (i.e office buildings, schools, etc.). This could have resulted in pragmatic solutions of mediating connections with the divine.

\subsection{Final Statement}

The design solution may be subject to individual perception of spirituality as it is such a personal and internal topic. Nevertheless, I conclude my thesis by noting that I have personally achieved what my intention for this research was; exploring how spaces can spiritually elevate our consciousness. 




\section{REFERENCES}

BOOKS

Adcock, Craig E., and Turrell, James. James Turrell: The Art of Light and Space. Berkeley: University of California Press, 1990.

Barrie, Thomas. Spiritual Path, Sacred Place: Myth, Ritual, and Meaning in Architecture. Boston: Shambhala, 1996.

Barrie, Thomas. The Sacred In-between: The Mediating Roles of Architecture. Abingdon, Oxfordshire: Routledge, 2010.

Benedikt, Michael. For an Architecture of Reality. New York: Lumen Books, 1987. (32-56)

Bergmann, Sigurd. Architecture, Aesth/ethics \& Religion. Frankfurt Am Main: IKO-Verlag Für Interkulturelle Kommunikation, 2005.

Botta, Mario. "Sacred Space" in Architetture Del Sacro: Prayers in Stone. Ed. Gabriele Cappellato. Bologna: Editrice Compositori, 2005. Print.

Britton, Karla Cavarra. "Prologue: The Case for Sacred Architecture" In Constructing the Ineffable: Contemporary Sacred Architecture. Ed. Karla Britton. New Haven, Conn.: Yale School of Architecture: 2010 .

Bruce, Steve. God Is Dead: Secularization in the West. Malden, MA: Blackwell Publishing, 2002.

Cannon, Jon. The Secret Language of Sacred Spaces: Decoding Churches, Temples, Mosques and Other Places of Worship around the World. London: Duncan Baird Publishers, 2013.

Coelho, Paulo. The Alchemist. San Francisco: Harper Collins, 1993.

Coelho, Paulo, and Alan Clarke. The Pilgrimage. London: Harper Collins, 2005.

Corbusier, Le. L'espace Indicible. Boulogne-sur-Seine: Architecture D'aujourd'hui, 1946. (7-9)

Corbusier, Le. New World of Space. Trans. New York: Reynal \& Hitchcock; Boston : Institute of Contemporary Art, 1948.

Dawkins, Richard. The God Delusion. Boston: Houghton Mifflin, 2008.

Descartes, René. Discourse on Method and Meditations - Dover Books on Western Philosophy. Trans. Elizabeth Sanderson Haldane. New York: Courier Corporation, 2003.

Eco, Umberto, Farina, Caterina and Farina Geoff. How to Write a Thesis. Cambridge, Mass.: MIT Press, 2015.

Eliade, Mircea, and Willard R. Trask. The Sacred and the Profane: The Nature of Religion. New York: Harcourt, Brace \& World, 1959.

Fordham, Frieda. An Introduction to Jung’s Psychology. Harmondsworth: Penguin Books, 1975.

Foucault, Michel, and Rabinow, Paul. The Foucault Reader. Harmondsworth: Penguin Books, 1991. 
Frampton, Kenneth. "The Secular Spirituality of Tadao Ando." In Constructing the Ineffable: Contemporary Sacred Architecture. Ed. Karla Britton. New Haven, Conn.: Yale School of Architecture: 2010.

Harries, Karsten. "Untimely Meditations on the need for Sacred Archtitecture" In Constructing the Ineffable: Contemporary Sacred Architecture. Ed. Karla Britton. New Haven, Conn.: Yale School of Architecture: 2010 .

Jung, Carl G. Man and His Symbols. Ed. Marie-Luise Von Franz. New York: Dell Publishing, 1968.

Jung, Carl G. The Archetypes and the Collective Unconscious. New Jersey: Princeton Press, 1981

MacDonald, William L. The Pantheon: Design, Meaning, and Progeny. Cambridge, Mass.: Harvard University Press, 2002.

Michell, George. The Hindu Temple: An Introduction to Its Meaning and Forms. Chicago: University of Chicago Press, 1988. (71-79)

Merrill, Michael. Louis Kahn on the Thoughtful Making of Spaces the Dominican Motherhouse and a Modern Culture of Space. Baden: Lars Müller, 2010

Nietzsche, Friedrich. Thus Spoke Zarathustra. Trans. Walter Kaufmann. London; Penguin Books, 1978, original 1883.

Nye, Malory. Religion: The Basics. London: Routledge, 2003.

Padovan, Richard. Proportion: Science, Philosophy, Architecture. London: E \& FN Spon, 1999.

Pevsner, Nikolaus. An Outline of European Architecture. Harmondsworth: Penguin Books, 1957.

Pollio, Marcus Vitruvius. The Ten Books on Architecture. Ed. Morris Hicky Morgan. New York: Dover Publications, 1960.

Richardson, Phyllis. New Sacred Architecture. London: Laurence King, 2004.

Safdie, Moshe. "The Architecture of Memory: Seeking the Sacred." In Constructing the Ineffable: Contemporary Sacred Architecture. Ed. Karla Britton. New Haven, Conn.: Yale School of Architecture: 2010.

Scully, Vincent. "The Earth, the Temple, and Today" In Constructing the Ineffable: Contemporary Sacred Architecture. Ed. Karla Britton. New Haven, Conn.: Yale School of Architecture: 2010.

Simpkins, C. Alexander, and Simpkins, Annellen M. Simple Tibetan Buddhism: A Guide to Tantric Living. Boston: Tuttle Pub., 2001.

Volf, Miroslav. "Architecture, Memory, and the Sacred" In Constructing the Ineffable: Contemporary Sacred Architecture. Ed. Karla Britton. New Haven, Conn.: Yale School of Architecture: 2010.

Wairama, Moira. The Taniwha of Wellington Harbour. Illustrated by Bruce Potter. Auckland, New Zealand: Penguin Group, 2011. 
Warburton, David. Architecture, Power, and Religion: Hatshepsut, Amun \& Karnak in Context. Münster: LIT Verlag, 2012.

Wilson, Bryan R. Contemporary Transformations of Religion. London: Oxford University Press, 1976.

\section{ONLINE ARTICLES}

Cline, Austin. "Pantheon in Rome: History, Architecture of the Pantheon in Rome." About Religion \& Spirituality. December 15, 2014. Accessed August 2015.

<http://atheism.about.com/od/christianchurchchurches/p/PantheonRome.htm>

Coward, Harold "Mysticism in the Analytical Psychology of Carl Jung and the Yoga Psychology of Patañjali: a Comparative Study” Philosophy East and West. 29 (1979): 323-336. Accessed May 2015. <http://www.jstor.org/stable/1398935>

Eliade, Mircea "The Sacred in the Secular World." Philosophy Social Criticism. 1 (1973): 101-13.

Accessed June 2015. <http://philpapers.org/rec/ELITSI.>

"Flashback: Yad Vashem Holocaust Museum / Safdie Architects." ArchDaily. October 31, 2011. Accessed June, 2015.

<http://www.archdaily.com/179679/yad-vashem-holocaust-museum-safdie-architects>

Glynn, Simon. "Chapel of Notre Dame Du Haut Ronchamp by Le Corbusier." Galinsky. 2011. Accessed May 2015. <http://www.galinsky.com/buildings/ronchamp/>

Lee Ann, Dzelzkalns. "Sacred Geometry." Mind, Body, Spirit Integration. Accessed January 2015. $<$ http://leeanndz.com/article/sacred-geometry/>

Perez, Adelyn. "AD Classics: Salk Institute / Louis Kahn.” ArchDaily. May 28, 2010. Accessed June 2015. <http://www.archdaily.com/61288/ad-classics-salk-institute-louis-kahn>

Phillips, Jock. "History of Immigration." Te Ara Encyclopedia of New Zealand. August 21, 2013. Accessed March 2015. <http://www.teara.govt.nz/en/history-of-immigration>

Philologos. "Roots of 'Religion”" The Forward. May 27, 2007. Accessed March 2015.

<http://forward.com/articles/10776/roots-of-religion/>

Silloway, Kari. "Water Temple Hyogo Japan by Tadao Ando." Galinsky. Accessed June 2015.

$<$ http://www.galinsky.com/buildings/watertemple/>

Tan, Linlcoln, and Singh, Harkanwal. "State of Faith: Wellington Can't Believe It." The New Zealand Herald. May 13, 2015. Accessed April 2015.

$<$ http://www.nzherald.co.nz/nz/news/article.cfm?c_id=1\&objectid=11447823.>

"The Global Religious Landscape". The Pew Forum on Religion \& Public Life. Pew Research center. 18 December 2012. Accessed April 2015

<http://www.pewforum.org/2012/12/18/global-religious-landscape-exec/> 
Witcombe, Christopher. "Sacred Places: Water and the Sacred." Sacred Places: Water and the Sacred. Accessed July 2015. <http://witcombe.sbc.edu/sacredplaces/water.html.>

WEBSITES

Abrams, Paula. "The Water Page - Water in Religion." The Water Page. Accessed July 2015.

$<$ http://www.africanwater.org/religion.htm.>

“Carlo Scarpa." Fondazione Querini Stampalia. Accessed August, 2015.

<http://www.querinistampalia.org/eng/contemporary/architecture/carlo_scarpa.php\#/>

"Introduction." James Turrell. 2015. Accessed August 2015.

$<$ http://jamesturrell.com/about/introduction/.>

“Moshe Safdie (1938- )." Accessed August 2015.

<http://aoc.mcgill.ca/greatest-mcgillians/moshe-safdie.>

"Mt. Victoria (Centennial) Lookout." Mt Victoria Historical Society. Accessed April 2015.

http://mtvictoria.history.org.nz/mt-victoria-centennial-lookout/.>

“Navigator Mt Victoria Tracks." Accessed April, 2015. <http://tracks.org.nz/area/show/5.>

"Ngake and Whataitai the Taniwha of Wellington Harbour." Maori Myths, Legends and Contemporary Stories. Accessed September 2015.

$<$ http://eng.mataurangamaori.tki.org.nz/Support-materials/Te-Reo-Maori/Maori-Myths-Legends-andContemporary-Stories/Ngake-and-Whataitai-the-taniwha-of-Wellington-harbour.>

"VASTU PURUSHA MANDALA." Architecture Ideas RSS. October 22, 2008. Accessed June 2015 $<$ http://architectureideas.info/2008/10/vastu-purusha-mandala/.>

"Wellington - Centennial Memorial." Statutes - Hither \& Tither. Accessed April 2015.

<http://www.vanderkrogt.net/statues/object.php?record=nz019\&webpage=ST.>

\section{VIDEOS}

“Carlo Scarpa.” Directed by Murray Grigor. Concord Media, 1996. Film Documentary.

“PHILOSOPHY - Michel Foucault”. The School of Life. Mad Adam Films. 2015. YouTube video.

OTHER

"Census." Census Data. Statistics New Zealand December 8, 2015. Accessed December 30, 2015. $<$ http://www.stats.govt.nz/Census.aspx.>

“MOUNT VICTORIA-MATAIRANGI MASTER PLAN". Pdf by Wraight Associates Limited, Wellington: Wellington City Council, June 2015.

Yoga Sutra I:41. - Patañjali 


\section{SOURCE OF FIGURES}

All Figures are by Author unless listed

Figure 12) Synagogue LJG by seARCH Architect, Amsterdam: author's own, adapted from original image: Iwan Baan. <http://www.archdaily.com/198818/synagogue-search>

Figure 13 a) Omphalos Stone in the Hagia Sophia:

<http://istanbul.for91days.com/category/sultanahmet/>

Figure 13 b) The Blue Mosque: Henrik Berger Jørgensen (2010)

<https://www.flickr.com/photos/darkb4dawn/480882280>

Figure 14) Hadrian's Pantheon Plan and Section Drawing: author's own, adapted from original image: PLAN:

<https://en.wikipedia.org/wiki/Pantheon,_Rome\#/media/File:Dehio_1_Pantheon_Floor_plan.jpg> SECTION:

<https://www.studyblue.com/notes/note/n/unit-2-module-9-images/deck/6418519>

Figure 15 a) Vaastu Purusha Mandala: author's own, adapted from original image:

Michell, George. The Hindu Temple: An Introduction to Its Meaning and Forms. 71-79

Figure 15 b) Fibonacci Sequence: 〈https://commons.wikimedia.org/wiki/File:Fibonacci_spiral_34.svg>

Figure 16) Matrix (research)

a) San Josemaría Escrivá Church by Javier Sordo Madaleno Bringas, Mexico: Fran Parente (2008) <http://www.archdaily.com/97520/iglesia-san-josemaria-escriva-javier-sordo-madaleno-bringas>

b) The Golden Temple (Sikh religion temple derived from Hinduism) by Guru Ram Das, India: Guilhem Vellut (2005) <https://www.flickr.com/photos/22539273@N00/66103914>

c) Amaravati Buddhist Monastery by Tom Hancock, England: (2013)

<http://www.panoramio.com/photo/51224093>

d) Sheikh Zayed Mosque by Yusef Abdelki, United Arab Emirates: Dibyendu Biswas (2011) <https://www.flickr.com/photos/dibyendubiswas/5455501468>

e) Beth El Synagogue by Stanley Saitowitz and Natoma Architects, California, USA: Rien van Rijthoven. (2000) <http://www.archdaily.com/32779/beth-el-stanley-saitowitz-natoma-architects>

f) Parish Church of Santa Monica by Vicens \& Ramos, Spain: (2008)

$<$ http://www.archdaily.com/26101/parish-church-of-santa-monica-vicens-ramos>

g) Amber Fort/ Amer Palace by Raja man Singh, India: Vssun (2010)

<https://commons.wikimedia.org/wiki/File:Amber_Fort_-_Screen_at_Ganesh_Pol_2.jpg>

h) Water-Moon Monastery by Artech Architects, Taiwan: Jeffrey Cheng (2012)

<http://www.archdaily.com/330486/water-moon-monastery-artech-architects/> 
i) Sancaklar Mosque by Emre Arolat Architects, Turkey: Thomas Mayer (2012)

<http://www.archdaily.com/516205/sancaklar-mosque-emre-arolat-architects>

j) New Synagogue Dresden by Wandel Hoefer Lorch + Hirsch, Germany: Norbert Miguletz <http://www.archdaily.com/318277/flashback-new-synagogue-dresden-wandel-hoefer-lorch-hirsch>

k) The Cathedral of St. Mary of the Assumption by Pier Nervi, California, USA: dhophotography (2011) <https://www.flickr.com/photos/dho81/5725115116/in/photostream/>

1) Lotus Temple (Bahai's faith influenced by Hinduism and Zorastrianism) by Fariborz Sahba, India: Adib Roy <https://www.flickr.com/photos/manunited/albums/72157620572238522>

m) Wat Ananda Metyarama Thai Buddhist Temple by Czarl Architects, Singapore: MingFu Weng (2014)

<http://www.archdaily.com/547649/wat-ananda-metyarama-thai-buddhist-temple-czarl-architects>

n) Al Rawda Mosque by Uraiqat Architects, Jordan: Urqait Architects (2012)

$<$ http://www.ur-arch.com/?portfolio=al-rawda-mosque-amman>

o) Ulm Synagogue by Kister Scheithauer Gross, Germany: Christian Richters (2009)

<http://www.dezeen.com/2012/12/18/ulm-synagogue-by-kister-scheithauer-gross/>

Figure 17 a) Bicycle Shed, London: David Hawgood (2006)

<http://www.geograph.org.uk/photo/215027>

Figure 17 b) Lincoln Cathedral Nave, Linconlnshire: Diliff (2014)

<https://commons.wikimedia.org/wiki/File:Lincoln_Cathedral_Nave_1,_Lincolnshire,_UK_-_Diliff. jpg>

Figure 18) Turning Torso by Santiago Calatrava, Sweden: Väsk (2001)

<https://commons.wikimedia.org/wiki/File:Turning_Torso_och_Bo01_2.jpg>

Figure 19) 9/11 Memorial by Handel Architects, Peter Walker and Davis Brody Bond, New York, USA: The White House's photostream

<https://commons.wikimedia.org/wiki/File:Obama_Bush_at_National_911_Memorial.jpg>

Figure 22-25) Author's own adapted from Koordinates:

<https://koordinates.com/layer/1431-wellington-city-suburbs/>

Figure 32-33, 35-36, 38-39) Water Temple: Author's own adapted from original image: Ken Conley <http://kwc.org/photos/tadao-ando/water-temple-shingonshu-honpukuji/>

Figure 34) Water Temple Plan: Author's own adapted from original image: satyagraaha <https://www.flickr.com/photos/73343706@No0/sets/72157628421508755/>

Figure 37) Water Temple Vermilion Lattice with light: Ou Kinhaku <http://www.tofugu.com/2012/12/01/awaji-islands-breathtaking-architecture/> 
Figure 40, 45 a, b) Yad Vashem Museum: Timothy Hursley

<http://www.archdaily.com/179679/yad-vashem-holocaust-museum-safdie-architects>

Figure 41, 43) Yad Vashem Museum: Author's own adapted from original image: Timothy Hursley <http://www.archdaily.com/179679/yad-vashem-holocaust-museum-safdie-architects>

Figure 42, 44) Yad Vashem Museum Drawings: Author's own adapted from original image:

<http://www.arcspace.com/features/moshe-safdie-/holocaust-history-museum/>

Figure 46, 47 a, b) Querini Stampalia: Design Life net work (2013)

<http://designlifenetwork.com/interior-alchemy-carlo-scarpas-palazzo-querini-stampalia/>

Figure 48, 49) Querini Stampalia: Author's own adapted from original image: Design Life net work (2013) <http://designlifenetwork.com/interior-alchemy-carlo-scarpas-palazzo-querini-stampalia/>

Figure 50) Querini Stampalia Plan drawing: Author's own adapted from original image:

<http://3six0.com/thoughts/presence-absence-carlo-scarpa-querini-stampalia-water/>

Figure 51, 52) Salk Institute: Author's own adapted from original image: Liao Yusheng

<http://www.archdaily.com/61288/ad-classics-salk-institute-louis-kahn>

Figure 53, 54 a, b) Salk Institute: Author's own adapted from original image: Stacy Spensley.

$<$ http://centerstagewellness.com/science-at-the-salk-institute/>

Figure 55) Pantheon 18th century, painting by Giovanni Paolo Panini: Author's own adapted from original image: Penn State University Libraries Architecture and Landscape Architecture Library <https://www.flickr.com/photos/psulibscollections/5833317924>

Figure 56) Pantheon Section drawing: Author's own adapted from original image:

MacDonald, William L. The Pantheon: Design, Meaning, and Progeny. Cambridge, Mass.: Harvard University Press, 2002. (page 13)

Figure 57, 58 a, b) Twilight Epiphany: Author's own adapted from original image: Beth Broome <http://www.architecturalrecord.com/articles/7899-twilight-epiphany>

Figure 59) Third Breath: (2005)

<http://jamesturrell.com/work/thirdbreath/>

Figure 63) Matrix (design)

a) Restaurant by Felix Candela: Felipe Gabaldón (2013)

<https://www.flickr.com/photos/felipe_gabaldon/>

b) Lotus Temple by Fariborz Sahba, India: Adib Roy

<https://www.flickr.com/photos/manunited/albums/72157620572238522>

c) Crematorium Baumschulenweg by Shultes Frank Architeckten: Mattias Hamrén

<http://www.archdaily.com/322464/crematorium-baumschulenweg-shultes-frank-architeckten> 
d) MIT Chapel by Eero Saarinen: Scott Norsworthy (2009)

<https://www.flickr.com/photos/scottnorsworthy/3478369283>

e) Cardedeu by EMC Arquitectura: Tom Arban

$<$ http://www.archdaily.com/582647/cardedeu-emc-arquitectura>

f) Sacred Museum and Plaza by Fernando Menis Architects: Simona Rota

$<$ http://menis.es/sacred-museum-and-plaza-spain-in-adeje/>

g) Meditation House by Pascal Arquitectos:

$<$ http://cubeme.com/casa-de-la-meditation-by-pascal-arquitectos/>

h) Chapel in Valleacerón by S.M.A.O:

<http://openbuildings.com/buildings/chapel-in-valleaceron-profile-6187>

i) Hatlehol Church by Konrad Wójcik (concept):

<https://www.behance.net/gallery/13120097/HATLEHOL-CHURCH-A-SPIRITUAL-JOURNEY>

j) The Panteon Nube by Clavel Arquitectos: David Frutos Ruiz (2011)

$<$ http://davidfrutos.com/panteonnube/>

k) The Parabola by RMJM architects and OMA architects:

$<$ http://oma.eu/projects/commonwealth-institute>

1) Sancaklar Mosque by Emre Arolat Architects, Turkey: Thomas Mayer (2012)

<http://www.archdaily.com/516205/sancaklar-mosque-emre-arolat-architects>

Figure 67 a) Narvarte Church by Felix Candela:

$<$ https://architectureofdoom.wordpress.com/tag/church/page/21/ narvarte church>

Figure 67 b) Church of Christ the Worker by Eladio Dieste: Lomobaires

<https://www.flickr.com/photos/lomobaires/sets/72157621941747281/>

Figure 71 a) Futuna Chapel by John Scott: Paul McCredie (2010)

<http://www.heritage.org.nz/the-list/details/7446>

Figure 71 b) Forest Chapel by Hironaka Ogawa Associates:

<http://www.archdaily.com/338049/forest-chapel-hironaka-ogawa-associates>

Figure 76 a, b) Axial and Split Path drawings: Photocopied from:

Barrie, Thomas. Spiritual Path, Sacred Place: Myth, Ritual, and Meaning in Architecture. Boston: Shambhala, 1996. (page 79 -111) 




\section{APPENDICES}

APPENDIX 1 - Census Data Tables

New Zealand Ethnic Population Table

\begin{tabular}{|l|r|r|r|}
\hline & 2001 & 2006 & 2013 \\
\hline Asian & 238,176 & 354,552 & 471,708 \\
\hline ME LA A & 24,924 & 34,743 & 46,953 \\
\hline Pacific & 231,801 & 265,974 & 295,941 \\
\hline
\end{tabular}

New Zealand Ethnic Population Increase from 2001 to 2013

\begin{tabular}{|l|r|r|r|r|}
\hline & 2013 & 2001 & Difference & \% Increase \\
\hline Asian & 471,708 & 238,176 & 233,532 & $98 \%$ \\
\hline ME LA A & 46,953 & 24,924 & 22,029 & $88.2 \%$ \\
\hline Pacific & 295,941 & 231,801 & 64,140 & $27.7 \%$ \\
\hline
\end{tabular}

New Zealand Decrease in Christianity from 2001 to 2013

\begin{tabular}{|r|r|r|r|r|}
\hline & 2013 & 2001 & Difference & $\%$ Decrease \\
\hline Christianity & $2,043,840$ & $1,906,398$ & 137,442 & $6.7 \%$ \\
\hline
\end{tabular}

New Zealand Population of Atheists

\begin{tabular}{|l|r|r|r|}
\hline & 2001 & 2006 & 2013 \\
\hline Atheism & $1,028,049$ & $1,297,104$ & $1,635,345$ \\
\hline
\end{tabular}

New Zealand Population of Religious

\begin{tabular}{|l|r|r|r|}
\hline & 2001 & 2006 & 2013 \\
\hline Buddhist & 41,634 & 52,362 & 58,404 \\
\hline Total Christians & $2,043,843$ & $2,027,418$ & $1,858,977$ \\
\hline Total Māori Christians & 63,597 & 65,550 & 52,947 \\
\hline Hindu & 39,798 & 64,392 & 89,919 \\
\hline Islam/Muslim & 23,631 & 36,072 & 46,149 \\
\hline Judaism/Jewish & 6,636 & 6,858 & 6,867 \\
\hline Total New Age Religions & 16,062 & 19,800 & 18,285 \\
\hline Total Other Religions & 18,780 & 24,450 & 34,245 \\
\hline Object to answering & 239,241 & 242,607 & 173,034 \\
\hline Total people stated & $3,468,813$ & $3,743,655$ & $3,901,167$ \\
\hline Religion unidentifiable & 287,376 & 292,974 & 347,301 \\
\hline Total Population & $3,737,277$ & $4,027,947$ & $4,242,048$ \\
\hline
\end{tabular}


APPENDIX 2 - The Pilgrimage: Paulo Coelho's Sword

Paulo Coelho belongs to the Regnum Agnus Mundi (RAM) order. For his initiation ceremony, he fails to do what is required by his master to gain a special sword. This sword is a symbol of acceptance into the organisation of RAM. The sword is given to Coelho's wife to hide along Camino de Santiago (The way of St James). Coelho is then asked to take the pilgrimage to Santiago de Compostela where he will find the answers to all his questions and eventually discover his sword.

APPENDIX 3 - The Maori Legend of Ngake summarised from Maori Mysths and Legends Website

The legend entails the story of two Taniwha brothers, which in Maori mythology are giant water creatures or monsters often considered as guardians. Their names were Ngake and Whataitai and they lived in Wellington harbour or Te Whanganuia-Tara, during the time when the harbour was in fact a large lake cut off from the sea. Ngake was an energetic and playful taniwha whereas Whataitai liked to dream and laze around in the sun. As they grew bigger the two of them needed more space to move around so Ngake decided he needed to be free from the boundaries of the lake and explore the deep sea. Whataitai also wanted to join Ngake in his adventure.

One day Ngake started to circle around the lake and with full speed. He crashed into the cliffs on the southern side and created a pathway to Te Moana o Raukawa (Cook Strait). Whataitai joined his brother but since he was not as strong as Ngake, he became trapped between the lake and the sea. He waited for the high tides to lift him and carry him over but they were not strong enough. Whataitai remained stuck in this position for many years until one day, a powerful earthquake lifted him up from the shallow water and he knew he was going to die. Whataitai's spirit transformed into a bird named Te Keo and flew to the closest mountain Matairangi or Mount Victoria. Te Keo looked down from the mountain to the life he had in the lake and all the friends he had made with the birds and the fish. Te keo then departed for the taniwha spirit world. The body of Whataitai remained washed up on shore and eventually turned into rocks and land formation, now known as Hataitai. It is said that Matairangi gazes down upon the body of Whataita and the peak of the mountain is still known as Tangi te Keo.

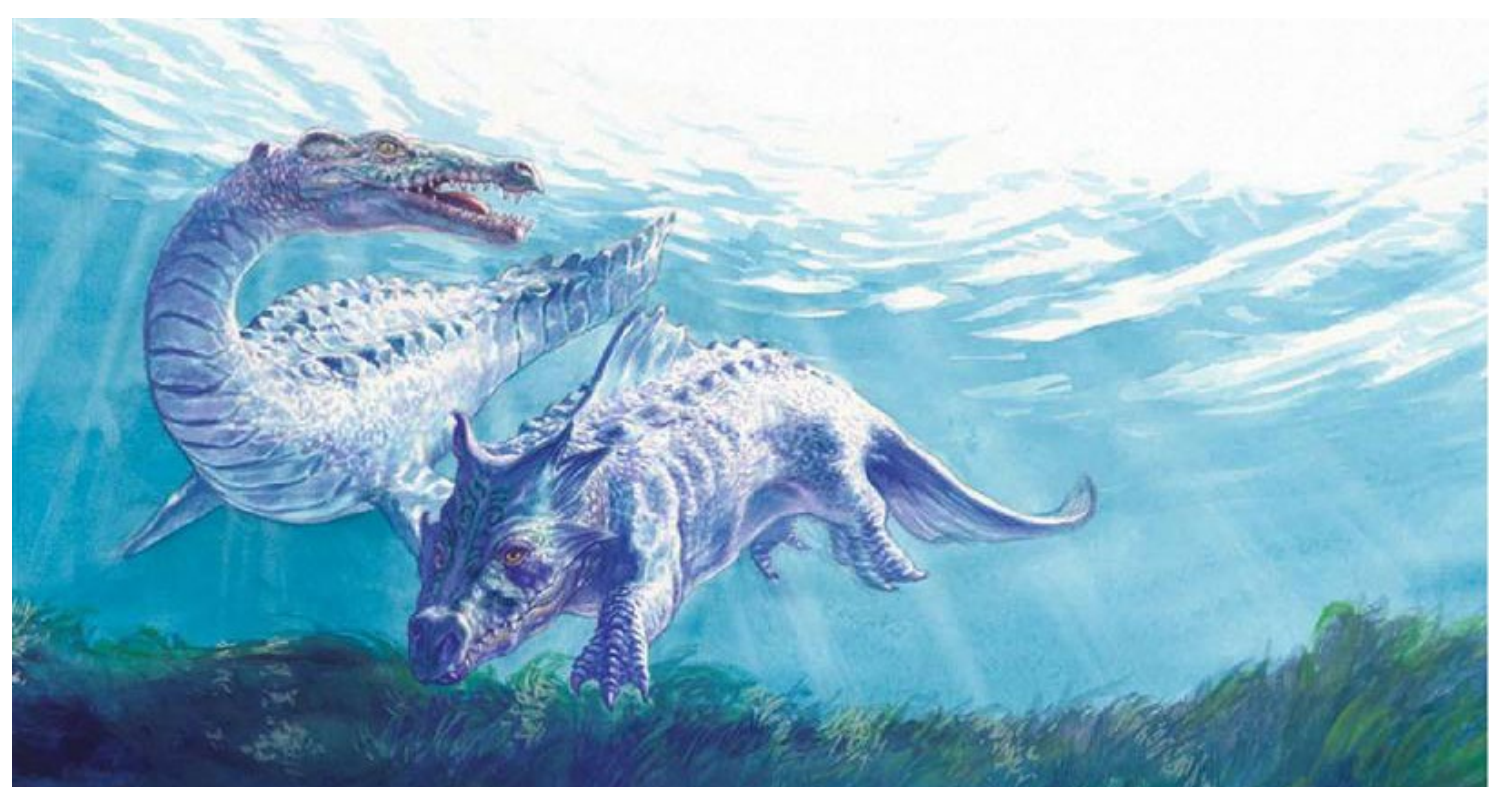

Illustration of Ngake and Whataitai by Bruce Potter in The Taniwha of Wellington Harbour.

Children's book written by Moira Wairama and published by Penguin Group, Auckland, New Zealand in 2011. 


\begin{tabular}{|c|c|}
\hline CHRISTIAN & JEWISH \\
\hline $\begin{array}{l}\text { CHURCH (basilicas, cathedrals, abbeys, medieval, byzantine, } \\
\text { gothic, modern, contemporary) }\end{array}$ & $\begin{array}{l}\text { SYNAGOGUE (place of worship and divine presence shekhinah } \\
\text { can be wherever } 10 \text { Jews assemble MINYAN quorum) } \\
\text { Egyptian revival, moorish (arab/spanish), modern }\end{array}$ \\
\hline $\begin{array}{l}\text { Architectural ELEMENTS/QUALITIES: } \\
\text { - } \quad \text { nave, aisle, transept, apse, alter, crossing, ambulatory, } \\
\text { chevette, narthex, towers } \\
\text { - } \quad \text { The house church (often underground, organic) } \\
\text { - } \quad \text { mausoleum (centrally planned building) } \\
\text { - } \quad \begin{array}{l}\text { Atrium. VERTICALITY } \\
\text { - }\end{array} \\
\quad \text { plan: Crucifix or Cruciform, Greek cross plan, Latin cross } \\
\text { - } \quad \text { arches, columns, domes, windows (light), tabernacle }\end{array}$ & 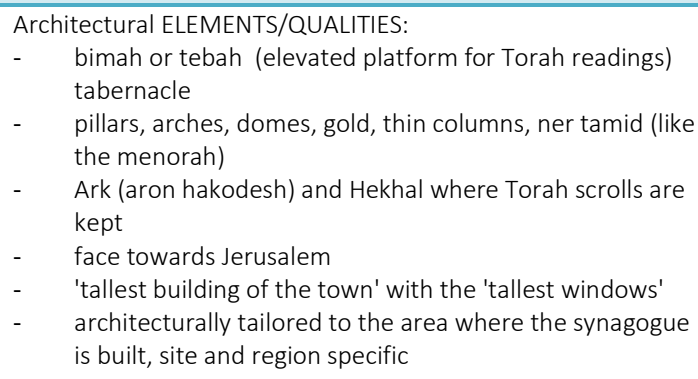 \\
\hline $\begin{array}{ll}\text { PRACTICES/RITUALS within the church } \\
- & \text { Singing } \\
- & \text { Prayers } \\
- & \text { Priest/Pastor gives Sermon (Bible) } \\
- & \text { mass } \\
- & \text { bread and wine, blessing }\end{array}$ & $\begin{array}{ll}\text { PRACTICES/RITUALS within the synagogue } \\
-\quad \text { Singing } \\
-\quad \text { Prayers } \\
-\quad \text { (separate for men and women) } \\
-\quad \text { Readings of the Torah (mostly old testament of the } \\
\text { Bible) } \\
-\quad \text { readings by the Rabbi }\end{array}$ \\
\hline
\end{tabular}

\begin{tabular}{|c|c|}
\hline HINDU & MUSLIM \\
\hline $\begin{array}{l}\text { TEMPLE (Mandir) Vesara, dravida (south India, pyramid } \\
\text { shaped stone), nagara (square in plan, tower inclining } \\
\text { inwards in elevation) }\end{array}$ & $\begin{array}{l}\text { MOSQUE ( Hypostyle, four-iwan, centrally planned) } \\
\text { byzantine influence. Ottoman mosque }\end{array}$ \\
\hline $\begin{array}{ll}\text { Architectural ELEMENTS/QUALITIES: } \\
- & \text { Vastu Shastra (science of construction and } \\
\text { - } & \text { architecture) mandala } \\
- & \text { derived from vedas } \\
- & \text { Hindu 'pantheon' } \\
- & \text { high plinth in a walled compound } \\
- & \text { water tanks for cleansing } \\
- & \text { steps (verticality) } \\
- & \text { stone arches } \\
- & \text { circular/concentric } \\
\text { inscriptions on the walls of the interior }\end{array}$ & $\begin{array}{ll}\text { Architectural ELEMENTS/QUALITIES: } \\
-\quad \text { arches and columns } \\
-\quad & \text { filigree screens } \\
- & \text { arabesque interior } \\
- & \text { courtyard sahn } \\
- & \text { minaret (lighthouse) } \\
- & \text { water for cleansing } \\
- & \text { domed ceilings } \\
- & \text { vaulted interior } \\
- & \text { mihrab with qibla (niche within a wall) } \\
- & \text { faces Mecca }\end{array}$ \\
\hline $\begin{array}{ll}\text { PRACTICES/RITUALS within the temple } \\
-\quad & \text { Singing } \\
- & \text { Prayers } \\
- & \text { (separate for men and women) } \\
- & \text { Vedic mantras and chanting } \\
- & \text { sacrifice at a fire alter } \\
- & \text { meditation } \\
- & \text { hymns, awakening with bells }\end{array}$ & $\begin{array}{ll}\text { PRACTICES/RITUALS within the mosque } \\
-\quad & \text { Prayers } \\
- & \text { (separate for men and women) } \\
- & \text { readings of the Quran } \\
- & \text { chanting/recital of verses in the Quran } \\
- & \text { hymns } \\
- & \text { five pillars of Islam }\end{array}$ \\
\hline
\end{tabular}




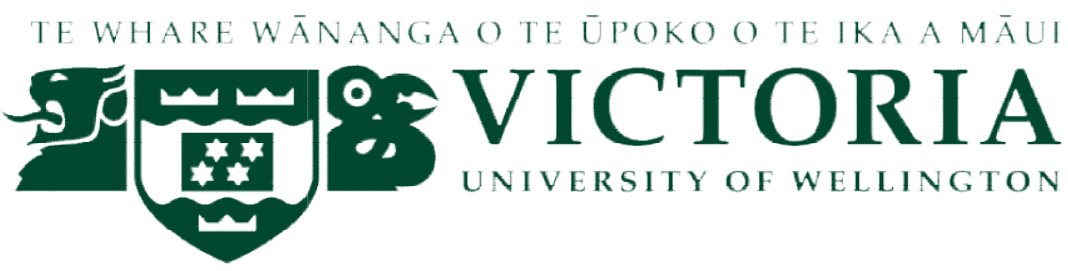

\section{PARTICIPANT INTERVIEW QUESTIONS}

\section{Project Title: Sacred Universal Sanctum}

\section{Questions for RELIGIOUS LEADERS AND FOLLOWERS}

(priests, pastors, ministers, padres, vicars, clergy, lamas, bhikkhus, mullahs, rabbis, kohens, brahmins, pujaris)

1) What architectural elements (seats/altar/windows/light etc.) are absolutely necessary for your religious space?

2) Are there any elements which should not interfere with your practice

3) Is there a need for an altar or could it be a series of transformable and adjustable platforms?

4) How much does the surrounding space or environment affect or influence the way you pray and practice your religion?

5) What is women's role in the process of rituals and prayers? How is it different from men's role? (do you need separate spaces)

6) Do you know of any overlaps in the practice of your religion with other faiths?

7) How would you react or perceive the idea of one universal space or place (ecumenical) which can be used other people of different religions and faiths?

8) Do you know of an example(s) of contemporary spaces that you think is ideal or 'perfect' to your religion or practice. 

For anyone from any religion seeking SPIRITUAL REALISATION through contemporary INTERIOR ARCHITECTURE 